\author{
UNIVERSIDADE DE SÃO PAULO \\ FACULDADE DE ECONOMIA, ADMINISTRAÇÃO E CONTABILIDADE \\ DEPARTAMENTO DE ADMINISTRAÇÃO \\ PROGRAMA DE PÓS-GRADUAÇÃO EM ADMINISTRAÇÃO
}

\title{
O IMPACTO DA SECURITIZAÇÃO DE ATIVOS NOS INDICADORES FINANCEIROS E NO BETA DAS EMPRESAS
}

José Carlos Augusto Luxo

Orientador: Prof. Dr. Almir Ferreira de Sousa

São Paulo

2007 


\section{Reitor da Universidade de São Paulo}

Prof $^{a}$. Dra. Suely Vilela

Diretor da Faculdade de Economia, Administração e Contabilidade Prof. Dr. Carlos Roberto Azzoni

Chefe do Departamento de Administração

Prof. Dr. Isak Kruglianskas

Coordenador do Programa de Pós-Graduação em Administração

Prof. Dr. Lindolfo Galvão de Albuquerque 


\section{O IMPACTO DA SECURITIZAÇÃO DE ATIVOS NOS INDICADORES FINANCEIROS E NO BETA DAS EMPRESAS}

Tese de doutorado apresentada ao Departamento de Administração da Faculdade de Economia, Administração e Contabilidade da Universidade de São Paulo, como parte dos requisitos necessários para a obtenção do título de Doutor em Administração.

Orientador: Prof. Dr. Almir Ferreira de Sousa

São Paulo 


\section{FICHA CATALOGRÁFICA}

Elaborada pela Seção de Processamento Técnico do SBD/FEA/USP

\section{Luxo, José Carlos Augusto}

Impacto da securitização de ativos nos indicadores financeiros e no beta das empresas / José Carlos Augusto Luxo. - São Paulo, 2007. $234 \mathrm{p}$.

Tese (Doutorado) - Universidade de São Paulo, 2007 Bibliografia

1. Administração financeira 2. Securitização 3. Mercado de capitais 4. Investimentos 5. Finanças das empresas I. Universidade de São Paulo. Faculdade de Economia, Administração e Contabilidade. II. Título.

$$
\text { CDD - } 658.15
$$




\section{AGRADECIMENTOS}

"Toda a Escritura é inspirada por Deus e útil para o ensino, para a repreensão, para a correção e para a instrução na justiça"

(II Timóteo 3.16).

A Deus, fonte de toda sabedoria, pela força e sustentação que nos concedeu, permanecendo ao nosso lado em todos os momentos desta caminhada.

Ao Prof. Dr. Almir Ferreira de Sousa, amigo e orientador, pelo ensino teórico e prático da Administração Financeira e grande incentivador da pesquisa científica voltada para a expansão da fronteira do conhecimento.

Ao Prof. Dr. José Roberto Securato, que me incentivou e conduziu nos caminhos da minha carreira docente e exemplo de postura acadêmica na dedicação para o desenvolvimento permanente da área de Finanças da FEA-USP.

Ao Prof. Dr. Edson Ferreira de Oliveira, pela cuidadosa revisão do projeto apresentado no exame de qualificação e pelas importantes sugestões oferecidas para o desenvolvimento deste trabalho.

Aos demais professores do Departamento de Administração da FEA-USP, em especial ao Prof. Dr. André Oda, Prof. Dr. Carlos Alberto Luporini, Prof. Dr. José Roberto Savoia, Prof. Dr. Keyler Carvalho Rocha e Prof. Dr. Wadico Bucchi.

Ao Prof. José Carlos Aquino e Professora Adriana Bauer, pela cuidadosa revisão do texto da tese.

A todos os funcionários da FEA-USP, especialmente aos da Seção de PósGraduação e do Serviço de Biblioteca e Documentação.

Aos colegas da Pós-Graduação da FEA-USP, em especial ao Prof. Dr. Antonio Carneiro de Freitas e Lucas Mahal, pelo suporte estatístico sem o qual este trabalho não poderia ter sido realizado, e a Eduardo Pozzi, Flávio Málaga, Júnio Fuentes, 
Leonel Molero, Lílian Carrete, Rafael Pasquarelli, Raquel Freitas de Oliveira e Rosana Tavares, pelo apoio e icentivadores constante.

Aos colegas do Laboratório de Finanças da FIA-FEA-USP, em especial a Patricia Oda e Carla Michele Ziruolo, que se envolveram nos primeiros estágios desta pesquisa. E a Fauzer Alves, pelo apoio na coleta dos dados.

Aos amigos, Bruno Amadei Júnior, Eduardo Abraão, Jorge Simão e Walter Cestari pelo apóio e motivação.

Em especial ao amigo Ricardo Humberto Rocha, que esteve sempre presente em todas as etapas deste trabalho com seu apóio e incentivo e pela amizade sincera.

À minha família, em especial aos meus pais, sogro, sogra, irmãos, cunhadas e cunhado, pelo carinho e compreensão.

À minha querida esposa Márcia Luxo, pelo amor e paciência em todos os momentos desta minha caminhada que construímos juntos, e aos meus amados filhos Renato, Flávio e Marcos pelo carinho e incentivo incondicional. A eles dedico de todo o meu coração este trabalho. 


\section{RESUMO}

Este trabalho avalia a influência da securitização de ativos sobre os indicadores financeiros e o beta das empresas que utilizam esse tipo de operação estruturada, por meio da aplicação de modelos teóricos e testes empíricos que relacionam conceitos de finanças corporativas com elementos da teoria de carteiras.

Os resultados indicam que há uma implicação entre o nível de endividamento e os critérios de rating de crédito e que é possível se estimar a força dessa implicação. A amostra desse estudo é composta por empresas que realizaram operações de securitização de recebíveis e também apresentaram ações negociadas na Bolsa de Valores de São Paulo durante o período compreendido entre 2000 a 2005, período em que se encontra a maior concentração do número de empresas que realizaram essas operações estruturadas de securitização. Para verificar a relação entre os indicadores financeiros e o beta de mercado com a securitização de recebíveis foram selecionados, além dos principais indicadores financeiros, o grau de alavancagem financeira, o grau de alavancagem operacional, o grau de alavancagem total, o beta de mercado das ações e o beta alavancado. A hipótese de existência de relações lineares entre essas medidas foi verificada por meio da aplicação de ferramentas matemáticas, testes estatísticos de associação e regressões simples e múltiplas, bem como a relação implicativa estatística fuzzy. Este trabalho também encontrou fortes evidências de que a securitização de ativos implica na melhora do rating de crédito das empresas que a utilizam. 


\begin{abstract}
This research analyzes the influence of asset securitization over the financial indicators and the beta of corporations which use this kind of structured operation. This influence is studied through the application of theoretical models and empirical tests which relate corporate finance concepts to portfolio theory elements.

The results indicate a relationship between corporate leverage and the credit rating criteria and the possibility to estimate the significance of such relationship. The research sample is composed of corporations which executed operations of receivable securitization and also had their stocks traded at the São Paulo Stock Exchange from years 2000 to 2005. Such sample period contains the largest number of corporate receivable securitization operations. To analyze the relationship between receivable securitization and financial indicators and between receivable securitization and market beta, the following variables were selected: financial leverage, operational leverage, total leverage, equity beta and asset beta. The fuzzy statistical relation and the linear relationship hypothesis between the dependent and independent variables, and between the independent variables themselves was tested through the application of mathematical tools, of statistical tests of association and of simple and multiple regression models. This research also found strong evidences that asset securitization leads to an improvement in credit rating, for the companies which adopt such structured operations.
\end{abstract}




\section{SUMÁRIO}

LISTA DE QUADROS

LISTA DE TABELAS $\quad 5$

LISTA DE GRÁFICOS $\quad 7$

LISTA DE FIGURAS $\quad 8$

CAPÍTULO 1 - INTRODUÇÃO

1.1 - Situação Problema 11

1.2 - Definição do Objetivo 14

1.3 - Metodologia do Trabalho 14

1.4 - Justificativa do Tema 15

1.5 - Descrição dos Capítulos 18

CAPÍTULO 2 - ESTRUTURA DA SECURITIZAÇÃO DE ATIVOS 19

2.1 - Financiamento do Capital de Giro 26

2.2 - Fontes Tradicionais de Financiamento do Capital de Giro 29

2.3 - Principais Aspectos e Características de Securitização 35

2.4 - Principais Características dos Participantes da Estrutura de

2.5 - Cessão de Crédito 53

2.5.1 - Tipos de Cessão de Crédito 55

2.5.2 - Tipos de Coobrigação $\quad 57$

2.6 - Os Modelos de Estruturas de Securitização de Ativos no Brasil $\quad 60$

2.7 - Fundos de Investimentos em Direitos Creditórios - FIDC 63

2.8 - Estudo Comparativo entre a Sociedade de Propósito Específico e os Fundos de Recebíveis - FIDC 72

CAPÍTULO 3 - METOdOLOGIAS dE AVALIAÇÃo E RATING DE EMPRESAS BRASILEIRAS $\quad 75$

$\begin{array}{ll}3.1 \text { - Rating de Empresas } & 77\end{array}$

3.1.1 - Características do Setor $\quad 79$

3.1.2 - Posição Competitiva da Empresa 79

3.2 - O Processo de Classificação $\quad 80$

3.3 - Descrição da Metodologia de Rating da Fitch Rating 89

3.4 - Descrição da Metodologia de Rating da Standard \& Poor's 92

3.5 - Descrição da Metodologia de Rating da Moody's 97

3.6 - Síntese das Metodologias de Rating 101

CAPÍTULO 4 - METODOLOGIA DA PESQUISA 104

4.1 - O Método da Pesquisa $\quad 104$

$\begin{array}{ll}4.2 \text { - Hipóteses Formuladas } & 107\end{array}$

4.3 - População e Amostra 109

4.4 - Coleta de Dados 111

4.5 - Indicadores Financeiros 111 
4.5.1 - Grupos de Índices Financeiros $\quad 111$

4.5.2 - Análise do Endividamento 113

4.6 - Alavancagem Financeira 114

4.7 - Alavancagem Operacional $\quad 117$

4.8 - Alavancagem Total 119

4.9 - Beta de Mercado $\quad 126$

4.10 - Dados Obtidos da Demonstração de Resultados do Exercício $\quad 135$

4.11 - As Demonstrações dos Fluxos de Caixa da Empresa 137

4.11.1 - Fluxo de Caixa Operacional (FCO) 137

4.11.2 - Fluxo de Caixa de Financiamento (FCF) 138

4.12 - Operacionalização das Variáveis 139

4.13 - Tratamento dos Dados 139

4.14 - Modelos Estatísticos Utilizados 139

4.14.1 - Coeficiente de Correlação de Pearson 139

4.14.2 - Coeficiente de Correlação de Spearman 144

4.14.3 - Regressão por Mínimos Quadrados Ordinários 145

4.14.4 - Análise Estatística Fuzzy e Implicativa 148

4.14.5 - Operador de Implicação 152

4.14.6 - Validação da Implicação 155

CAPÍTULO 5 - RESULTADOS OBTIDOS 156

$\begin{array}{ll}5.1 \text { - Cálculos dos Indicadores Financeiros Utilizando-se o Balanço } & \\ \text { Sem e Com a Securitização de Ativos } & 156\end{array}$

5.2 - Análise de Regressão 157

5.2.1 - Resultados das Regressões Lineares 160

5.2.2 - Relação entre os Graus de Alavancagem (GAT,GAF e GAO) e o Beta 160

5.2.3 - Relação entre os graus de alavancagem (GAT, GAF e 164 GAO) e o Beta Alavancado

5.2.4 - Relação entre os graus de alavancagem (GAT, GAF e GAO) e os índices de lucratividade economico e financeiro

5.2.5 - Resumo das relações encontradas no teste de hipóteses da pesquisa

5.4 - Resumo dos Resultados Encontrados nas Matrizes de Correlação de Pearson e Spearman

5.5 - Resultados da Análise Estatística Fuzzy 186

5.6 - Simulações com a Estatística Fuzzy 187

5.6.1 - Dados e Simulações 187

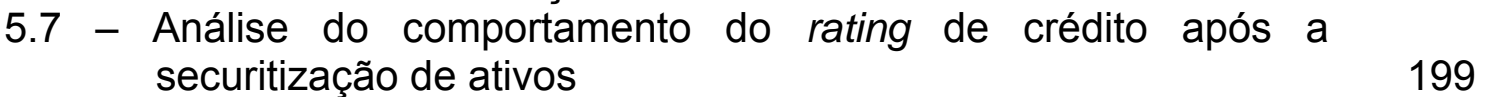


CAPÍTULO 6 - CONSIDERAÇÕES FINAIS 209

REFERÊNCIAS BIBLIOGRÁFICAS

$\begin{array}{ll}\text { ANEXOS } & 225\end{array}$

Anexo I - Empresas que utilizaram a securitização de ativos no período de 2000 a 2006

Anexo II - Ações Selecionadas para o Cálculo do Beta de Mercado 


\section{LISTA DE QUADROS}

Quadro1 - Principais Indicadores Financeiros Utilizados em Análise de Solvência

Quadro 2 - Principais produtos de empréstimos e suas características 30

Quadro 3 - Tipos e Principais Características das Operações de Financiamentos

Quadro 4 - Classificação de Títulos da Moody's e Standard \& Poor's

Quadro 5 - Características da Classificação dos Títulos

Quadro 6 - Normas regulamentares referentes à Cessão de Crédito

Quadro 7 - Distribuição das Operações Registradas na CVM - em \%

Quadro 8 - Empresas que lançaram FIDCs no mercado de capitais

71

Quadro 9 - Comparação de Custos Iniciais e de Manutenção

Quadro 10 - Despesas Tributárias

Quadro 11 - Hipóteses e indicadores das variáveis utilizadas na 108 pesquisa

Quadro 12 - Relação de Empresas Selecionadas

Quadro 13 - Relação entre a Estrutura de Capital e o CMPC no 123 Ambiente de Modgliani e Miller

Quadro 14 - Estrutura da Demonstração do Fluxo de Caixa 138 Operacional

Quadro 15 - Estrutura da Demonstração do Fluxo de Caixa de 138 Financiamento

Quadro 16 - Regressão do Beta em relação ao GAT,GAF e GAO

Quadro 17 - Regressão do Beta Alavancado em relação ao GAT,GAF e GAO

Quadro 18 - Regressão do índice de lucratividade econômica em relação aos três graus de alavancagem GAT, GAF e GAO

Quadro 19 - Regressão do índice de lucratividade financeira em relação aos três graus de alavancagem GAT, GAF e GAO

Quadro 20 - Matrizes de correlação e resultados observados 


\section{LISTA DE TABELAS}

Tabela 1 - Volume Anual Total de Securitização nos EUA 21

Tabela 2 - Probabilidade de default de uma empresa

86

Tabela 3 - Classificação de risco da Standard \& Poor's, Moody's e Fitch

Tabela 4 - Revisões dos ratings por meio de ocorrências

Tabela 5 - Relação das informações analisadas pela Fitch Rating

Tabela 6 - Relação das informações analisadas pela Standard \& Poor's

Tabela 7 - Relação das informações analisadas pela Moody's

100

Tabela 8 - Classificação de ratings

102

Tabela 9 - Principais Operadores de Implicação

153

Tabela 10 - Regressões dos betas em relação aos três graus de alavancagem (GAT, GAF e GAO), passando pela origem: sem securitização

160

Tabela 11 - Regressões dos betas em relação aos três graus de alavancagem (GAT, GAF e GAO), passando pela origem: com securitização

Tabela 12 - Regressões dos betas em relação aos três graus de alavancagem (GAT, GAF e GAO), não passando pela origem: sem securitização

Tabela 13 - Regressões dos betas em relação aos três graus de alavancagem (GAT, GAF e GAO), não passando pela origem: com securitização

Tabela 14 - Regressões dos betas alavancados em relação aos três graus de alavancagem (GAT, GAF e GAO), passando pela origem: sem securitização

Tabela 15 - Regressões dos betas alavancados em relação aos três graus de alavancagem (GAT, GAF e GAO), não passando pela origem: sem securitização

Tabela 16 - Regressões dos betas alavancados em relação aos três graus de alavancagem (GAT, GAF e GAO), passando pela origem: com securitização

Tabela 17 - Regressões dos betas alavancados em relação aos três graus de alavancagem (GAT, GAF e GAO), não passando pela origem: com securitização

Tabela 18 - Regressões do índice de lucratividade economica em relação aos três graus de alavancagem (GAT, GAF e GAO), passando pela origem: sem securitização

Tabela 19 - Regressões do índice de lucratividade economica em relação aos três graus de alavancagem (GAT, GAF e GAO), não passando pela origem: sem securitização

Tabela 20 - Regressões do índice de lucratividade economica em relação aos três graus de alavancagem (GAT, GAF e GAO), passando pela origem: com securitização

Tabela 21 - Regressões do índice de lucratividade economica em relação aos três graus de alavancagem (GAT, GAF e GAO), não passando pela origem: com securitização 
Tabela 22 - Regressões dos índices de lucratividade financeira em relação aos três graus de alavancagem (GAT, GAF e GAO), passando pela origem: sem securitização

171

Tabela 23 - Regressões dos índices de lucratividade financeira em relação aos três graus de alavancagem (GAT, GAF e GAO), não passando pela origem: sem securitização

172

Tabela 24 - Regressões dos índices de lucratividade financeira em relação aos três graus de alavancagem (GAT, GAF e GAO), passando pela origem: com securitização

Tabela 25 - Regressões do índice de lucratividade financeira em relação aos três graus de alavancagem (GAT, GAF e GAO), não passando pela origem: com securitização

Tabela 26 - Correlações de Pearson sem os efeitos da securitização

Tabela 27 - Correlações de Pearson sem os efeitos da securitização Normalizada

Tabela 28 - Correlações de Pearson com os efeitos da securitização

Tabela 29 - Correlações de Pearson com os efeitos da securitização Normalizada

Tabela 30 - Correlações de Spearman sem os efeitos da securitização

Tabela 31 - Correlações de Spearman sem os efeitos da securitização - Normalizada

Tabela 32 - Correlações de Spearman com os efeitos da securitização

Tabela 33 - Correlações de Spearman com os efeitos da securitização - Normalizada

Tabela 34 - Média e dispersão dos índices com e sem securitização de ativos

Tabela 35 - Resultados das implicações fuzzy sem a securitização de ativos

Tabela 36 - Resultados das implicações fuzzy com a securitização de ativos

Tabela 37 - Resultados das implicações fuzzy com a securitização de ativos

Tabela 38 - Resultados estatísticos e fuzzy com a securitização de ativos

Tabela 39 - Índicadores financeiros de classificação de rating (IFCR)

Tabela 40 - Média, desvio padrão e intervalo de $99 \%$ da distribuição dos indicadores financeiros

Tabela 41 - Tabela ANOVA com fator ano

Tabela 42 - Média, desvio padrão e tamanho da amostragem das duas amostra analisadas

Tabela 43 - Média, desvio padrão e tamanho da amostragem das duas amostras analisadas

Tabela 44 - Indicadores financeiros por classificação de título 


\section{LISTA DE GRÁFICOS}

Gráfico 1 - Balanço Anual de Hipotecas Securitizadas 23

Gráfico 2 - Ranking das operações de securitização fora dos EUA 23

Gráfico 3 - Ranking das Operações de Empréstimos e Financiamentos 33

Gráfico 4 - Distribuição Setorial de Operações de Securitização por Ativo-Lastro em 2006

Gráfico 5 - Spread de Risco Sobre o Título do Tesouro Americano 81

Gráfico 6 - Taxa Média de Inadimplência após 5, 10, 15 e 20 anos 85

Gráfico 7 - Relação entre a Estrutura de Capital e o CMPC no Ambiente $\begin{array}{ll}\text { Tradicional } & 124\end{array}$

Gráfico 8 - CMPC e Custo do Capital próprio na ausência de impostos 125

Gráfico 9 - CMPC e Custo do capital próprio quando $\tau_{c}>0 \quad 126$

Gráfico 10 - Diagrama de dispersão: Relacionamento positivo, perfeito 140

Gráfico 11 - Diagrama de dispersão: Relacionamento positivo, $\begin{array}{ll}\text { moderado } & 141\end{array}$

Gráfico 12 - Diagrama de dispersão: Relacionamento negativo, moderado 141

Gráfico 13 - Diagrama de dispersão: Ausência de relacionamento 142 


\section{LISTA DE FIGURAS}

Figura 1 - Fluxo de Securitização Sintética 39

Figura 2 - Estrutura Básica da Securitização de Ativos 42

Figura 3 - Estrutura da Cessão de Crédito entre Instituições Bancárias $\quad 58$

Figura 4 - Estrutura da Cessão de Crédito entre Bancos e Empresas $\quad 59$

Figura 5 - Estrutura dos Fundos de Direitos Creditórios - FIDC 67

Figura 6 - Fluxo Operacional dos Fundos de Direitos Creditórios $\quad 69$

$\begin{array}{ll}\text { Figura } 7 \text { - Definição gráfica de risco } & 78\end{array}$

Figura 8 - Fluxograma do processo de classificação de rating de crédito $\quad 83$

Figura 9 - Princípios para se atingir qualidade creditícia 93

Figura 10 - Alavancagem Financeira $\quad 114$

Figura 11 - Região de rejeição de três tipos (baixo, médio e alto) 154

Figura 12 - As regiões de rejeição foram escurecidas (não-implicação de A sobre B) 155 


\section{CAPÍTULO 1 - INTRODUÇÃO}

"Globalisation, the proliferation of trading platforms, product innovation, wider customer and market access and the ability of technology to cross national boundaries have all set a major regulatory challenge for financial service regulatory authorities".

Anthony Belchambers (Futures and Options Association)

Com a crescente internacionalização dos mercados financeiros e empresas, as autoridades governamentais deverão constantemente, adapatarem suas legislações aos novos instrumentos financeiros que desembarcam no país. A modernização do mercado de capitais é fundamental para o crescimento sustentável de qualquer economia no contexto global.

Nesse sentido, a securitização de ativos é uma operação estruturada que vêm provocando modernização do mercado de capitais brasileiro, bem como oferecendo alternativa inovadora na forma de captação de recursos de longo prazo para as empresas.

De acordo com Kothari (1999, p. 25) "securitization: the financial instrument of the new millennium".

Logo, as inovações financeiras buscam atender as necessidades de todas as comunidades bancárias e empresariais e de maneira cada vez mais globalizada. $\mathrm{O}$ mercado de capitais brasileiro está inserido nesse contexto através da operação estruturada de securitização.

O'Connell et al. (2000, p. 34), "over the past 25 years financial innovation has produced revolutionary changes in financial instruments and processes".

Pinheiro (2005, p.101), afirma que, inovações financeiras podem ser classificadas, segundo o BIS (Bank International Setlements), da seguinte forma:

"Inovações na transferência preço-risco. São aquelas que proporcionam meios mais eficientes aos participantes no mercado de certa forma tratar com o preço ou com o risco de câmbio;

Instrumentos de transferência crédito-risco. Têm como missão a redesignação do risco de insolvência;

Inovações geradoras de liquidez. São aquelas que aumentam a liquidez do mercado; permitem aos tomadores operar com novas fontes de financiamento; 
Instrumentos geradores de créditos. São aqueles que aumentam as quantidades de recursos financeiros alheios disponíveis pelas empresas".

Entre as inovações financeiras mais significativas dos últimos anos está a securitização de ativos, que é uma operação financeira estruturada cujo uso, cada vez maior, a destaca no mercado de capitais ao redor do mundo.

Miller (1986, p. 471) ressalta que: "the process of asset securitization has been regarded as a notable example of such innovation".

A securitização implica colocar os securities (títulos de renda fixa) junto aos investidores. Tais securities possuem um lastro específico, que são ativos a receber (recebíveis), e que, por sua vez, garantirão o pagamento desses securities, com o propósito de proteção de eventuais questionamentos quanto ao seu lastro (recebíveis).

Conforme Noronha (2004, p. 88), vale citar o nascimento quase acidental da terminologia (securitization), surgida nos EUA, utilizada na coluna da jornalista Ann Monroe, do Wall Street Journal. Ela entrevistou o autor da primeira operação do gênero, realizada no mercado imobiliário em 1977, e indagou-lhe que tipo de nome poderia atribuir àquele processo operacional. $O$ entrevistado descreveu como "securitization".

O termo securitização, utilizado no Brasil, é puro neologismo pelo aportuguesamento da expressão do idioma inglês securatization. Nos anos 70 , esse tipo de operação já existia no Brasil, porém, conhecida por outro nome, ou seja, algumas instituições financeiras concediam empréstimos com a garantia de ativos, que faziam parte da rubríca contábil contas a receber (recebíveis).

A securitização é uma operação estruturada para atender as necessidades de capital de giro de curto e longo prazos, com um custo de captação inferior às formas tradicionais de financiamento, como o crédito bancário. O crédito bancário na sua forma tradicional, apesar de ser a fonte de financiamento mais importante para as empresas da América Latina, geralmente, segundo o BID (2004, p. 5), é escasso, caro e volátil. 
Nesse sentido, as empresas, ao tomarem a decisão de utilizar esse novo instrumento de captação estruturado, partem da premissa, segundo Altman et al. (2000, p. 115), de que "a securitização leva a uma estrutura de custos mais baixos". Conseqüentemente, diminuirá o custo médio ponderado de capital. Porém, os impactos ocasionados nos indicadores financeiros e no beta, empiracamente, não são analisados pelas empresas que utilizam a securitização.

No mundo globalizado e sem fronteiras, a importância da oferta de crédito emerge como um ponto crucial para a sobrevivência das empresas de países em desenvolvimento ou emergentes. Nesse sentido, Ascarelli (1943, p. 3) destaca o papel do crédito, como um dos principais fundamentos da economia moderna.

Conforme o BIS (2001, p. 25), a expressão securitização possui o significado de:

\footnotetext{
"ato de tornar uma dívida qualquer com determinado credor em dívida com compradores de títulos no mesmo valor (a.s. da dívida externa brasileira). Conversão de empréstimo (bancário, p.ex.) e outros ativos em securities, a serem vendidas a investidores".
}

Esse trabalho, embora não enfoque os recebíveis que servirão de lastro para os securities, enfatiza a sua relação com as características da empresa, mensuradas por indicadores financeiros.

Essa tese pretende demonstrar os efeitos que a securitização pode produzir sobre os principais indicadores financeiros, como também, no beta das empresas que utilizam essa operação estruturada de captação de recursos financeiros.

Tal trabalho busca uma resposta para o problema de pesquisa que é a hipótese do impacto que a venda dos ativos do contas a receber, para a realização da operação de securitização, poderá causar nos indicadores financeiros e no beta das empresas.

\section{1 - Situação Problema}

A literatura financeira reconhece que o objetivo principal de uma empresa é a geração de valor para os seus acionistas e os administradores financeiros deverão identificar as melhores oportunidades de investimento, bem como buscar as formas 
mais eficazes de financiamento. Logo, a combinação dessas duas variáveis proporcionará a maximização do resultado dos acionistas.

Conforme Damodaran (2002, p. 320), maximizar o valor da empresa é selecionar financiamentos (inclui dívida e capital próprio) que maximizem os valores dos projetos selecionados e que casem com os ativos financiados.

Durand (1952, p. 239) foi um dos pioneiros na investigação comumente denominada de tradicionalista, ou seja, "uma combinação ótima de capital de terceiros e capital próprio pode ser obtida e deve ser buscada pelas empresas como forma de maximizar seu valor de mercado".

Nesse contexto, os administradores financeiros poderão utilizar a operação de securitização como alternativa de financiamento da gestão do capital de giro das empresas, visando a uma eficiência no seu custo de capital.

Essa forma de captação de recursos, de maneira estruturada, que é a securitização de ativos, vem sendo utilizada em diversos países, por várias empresas dos segmentos corporate e middle market, na busca de financiamento de crédito de curto e longo prazos, com custos de captação mais baixos do que as formas tradicionais, ou seja, os empréstimos bancários e a emissão de títulos de dívida como, por exemplo, as debêntures e os commercial papers (notas promissórias comerciais).

O tema securitização evoluiu nos últimos cinco anos, no Brasil, apesar ser bem sucedido tanto nos EUA, desde o final dos anos 70, quanto na Europa. De acordo com Altman et al. (2000, p. 115), as raízes da securitização estão nos títulos garantidos por ativos, que são simplesmente a versão do mercado de capitais para os empréstimos garantidos por ativos.

Conforme Toneto (1996, p. 1), "por que estudar o financiamento de longo prazo no período recente? A justificativa recai no fato já apontado por uma série de autores sobre a importância assumida pelo esgotamento do padrão de financiamento." Os agentes econômicos buscam constantemente a inovação financeira para sustentar o financiamento do crescimento das empresas privadas. 
Segundo o BID (2004, p. 5), sem a presença de mercados de crédito desenvolvidos e estáveis, será muito difícil que os países emergentes alcancem taxas de crescimento elevadas e sustentáveis.

Em diversos estudos acadêmicos, a operação estruturada de securitização de ativos é conhecida como uma operação off-balance sheet (fora do balanço) na medida em que não impacta a conta de passivo circulante (recursos onerosos), nem tampouco a de exigível de longo prazo, em comparação com as operações de crédito tradicionais, seja pela emissão de títulos, bem como pelas operações de empréstimo bancário.

"Off-balance sheet financing is most advantageous for sponsoring firms that are risky or face large bankruptcy costs". (GORTON e SOULELES, 2005. p. 1).

Nessa modalidade de operação estruturada, um dos itens do balanço patrimonial das empresas que são as contas a receber, representam geralmente, um dos mais importantes ativos das empresas. São valores a receber decorrentes de vendas a prazo de mercadorias e serviços a clientes, ou de outras transações.

Esses valores a receber, conhecidos também como recebíveis, serão o lastro principal para a securitização de ativos e, portanto, de acordo com o princípio contábil, serão creditadas (baixadas) e, conseqüentemente, terá uma entrada de recursos monetários que será utilizado para o financiamento do capital de giro ou mesmo para investimentos de médio ou longo prazos.

A securitização de ativos, também chamada de securitização de recebíveis, deve ser entendida, como ressalta Noronha (2004, p. 28), como um mecanismo de autofinanciamento empresarial tal qual as sociedades anônimas, ou seja, as empresas S/A podem emitir títulos e valores mobiliários (ações, debêntures) no mercado de capitais e, por isso, segundo o mesmo autor, a securitização é equiparada a esses títulos e valores mobiliários, pois é um contrato mercantil de cessão de lastro para emissões de valores mobiliários. 


\section{2 - Definição do Objetivo}

O objetivo central dessa pesquisa é investigar, cientificamente, os impactos ocasionados nos principais indicadores financeiros e no beta das empresas (beta de mercado das ações e beta alavancado), quando optam ou não pela operação estruturada de securitização de ativos, ou seja, mensurar especificamente os impactos ocorridos nos indicadores financeiros, pela venda dos recebíveis que compõem seu ativo a receber.

O objetivo secundário consistirá em examinar o comportamento do rating de crédito (classificação do risco de crédito) das empresas que realizam a venda de recebíveis por meio da operação de securitização de ativos.

\section{3 - Metodologia do Trabalho}

Conforme Demo (1995, p. 11), metodologia tem o significado, na origem do termo, de estudo dos caminhos, dos instrumentos usados para se fazer ciência.

O principal objetivo do presente trabalho é o de apresentar evidências empíricas do impacto que a securitização de ativos pode causar nos indicadores financeiros e no beta contábil das empresas que utilizam essa forma estruturada de captação de recursos de longo prazo.

Para verificar a relação entre a securitização de ativos e os indicadores financeiros e betas das empresas é necessário selecionar os indicadores financeiros que representam as características das empresas que se pretende analisar, além de definir os procedimentos para estimação dos betas das empresas analisadas.

De acordo com Altman et al. (2000, p. 99), os principais indicadores financeiros comumente utilizados nas análises de solvência das empresas são os apresentados no quadro a seguir: 
Quadro1 - Principais Indicadores Financeiros Utilizados em Análise de Solvência

\begin{tabular}{|c|l|}
\hline Categoria & \multicolumn{1}{|c|}{ Índice } \\
\hline \multirow{3}{*}{ Desempenho Operacional } & EBITDA / Faturamento \\
& Receita Líquida / Faturamento \\
& Taxa de Tributação Efetiva \\
& Receita Líquida / Patrimônio Líquido \\
& Receita Líquida / Ativo Total \\
& Faturamento / Ativo Fixo \\
\hline Cobertura do Serviço da Dívida & EBITDA / Juros \\
& Fluxo de Caixa Livre \\
\hline & Dívida de LP / Patrimônio Líquido \\
& Passivo Total / Patrimônio Líquido \\
& Passivo Circulante / Patrimônio Líquido \\
\hline & Liquidez Corrente \\
\hline Liquidez & Liquidez Seca \\
\hline & Estoque / Faturamento Líquido \\
& Estoque / Capital de Giro Líquido \\
& Dívida Circulante / Estoques \\
\hline Recebíveis & Maturidade dos Recebíveis \\
& Prazo Médio de Recebimento \\
\hline &
\end{tabular}

Fonte: Altman et al. (2000, p.100)

Para atender ao objetivo secundário será analisado o comportamento do rating de crédito, ou seja, o comportamento do rating estabelecidos pela agências de rating de crédito, (Moody`s, Standard \& Poor's e Fitch), antes da operação de securtização e após o início da securititização de ativos.

A hipótese de existência de alguma relação entre essas medidas foi verificada por meio das análises de regressões, correlações e estatística implicativa fuzzy.

As tabelas completas de indicadores e testes estatísticos utilizados, assim como o detalhamento da metodologia, podem ser encontrados no capítulo 4 - Metodologia de Pesquisa.

\section{4 - Justificativa do Tema}

O mercado de capitais, por natureza própria, é dinâmico e cada vez mais globalizado, permitindo que experiências de operações mais estruturadas, em países desenvolvidos, sejam também aplicadas em países que buscam o desenvolvimento econômico mais intenso. Além disso, um mercado de capitais 
desenvolvido consegue financiar o crescimento das empresas públicas e privadas, por meio do lançamento de valores mobiliários.

A legislação brasileira não conceitua o que são valores mobiliários, mas define, pelo critério de enumeração, os papéis que devem receber essa qualificação, de acordo com a Lei 6.385 , de 07.12 .1976 , artigo $2^{\circ}$, e redação atual dada pela Lei 10.303 , de 2001:

"são valores mobiliários sujeitos ao regime desta lei:

I - as ações, as debêntures e os bônus de subscrição;

II - os cupons, direitos, recibos de subscrição e certificados de desdobramento relativos aos valores mobiliários acima mencionados;

III - os certificados de depósitos de valores mobiliários;

IV - as cédulas de debêntures

$\mathrm{V}$ - as cotas de fundos de investimento em valores mobiliários ou de clubes de investimento em quaisquer ativos

$\mathrm{VI}$ - as notas comerciais;

VII - os contratos futuros, de opções e outros derivativos, cujos ativos subjacentes sejam valores mobiliários;

VIII - outros contratos derivativos, independentemente dos ativos subjacentes;

IX - e, quando ofertados publicamente, quaisquer outros títulos ou contratos de investimento coletivo, que gerem direito de participação, de parceria ou de remuneração, inclusive resultante de prestação de serviços, cujos rendimentos advêm do esforço do empreendedor ou de terceiros".

Conforme Noronha (2004, p. 31), poder-se-ia definir tais títulos como:

"títulos negociáveis em massa, emitidos em série, por sociedades anônimas abertas, mediante registro da emissão na Comissão de Valores Mobiliários, fungíveis ou não, suscetíveis de negociação em bolsas de valores ou mercado de balcão, com cotação no mercado..., podendo o seu rol ser ampliado, a critério do próprio legislador pátrio, ou consoante o mérito, conveniência e oportunidade do Conselho Monetário Nacional".

O mercado de capitais desenvolvido é aquele que proporciona uma proteção legal aos investidores, por meio da existência de um conjunto de leis e regras de mercado transparentes. 
Ao longo das últimas décadas, os mercados financeiros vêm desenvolvendo diversas inovações financeiras com o objetivo de atender as necessidades das empresas, sejam elas globalizadas ou não.

Essas inovações podem ser caracterizadas como instrumentos financeiros que permitem lidar com os novos desafios que surgem nos mercados de capitais globalizados, sempre buscando formas mais eficientes de financiamento e de proteção aos investidores.

Como exemplo de inovação financeira, Benzin et al. (2003, p. 37) cita os derivativos de crédito, que são instrumentos usados para proteção do risco de crédito. Tais derivativos foram introduzidos pelos bancos dos EUA, na década de 1990, para ajudá-los a aproveitar os benefícios da concentração de ativos de crédito sem assumir o risco parcial ou total correspondente ao ativo de crédito.

Nesse contexto, a securitização de ativos, também é considerada inovação financeira, objeto central desse trabalho.

A securitização de recebíveis foi desenvolvida para possibilitar às empresas uma nova fonte de financiamento ou captação de recursos, porém é necessário que a empresa tenha créditos ou recebíveis em seu ativo.

De acordo com essa operação estruturada, os recebíveis são isolados ou segregados da empresa originadora e repassados a uma sociedade neutra (Sociedade de Propósito Específico - SPE) para, posteriormente, serem utilizados como lastro ou suporte de uma emissão de debêntures.

Nesse contexto, a empresa terá o ingresso de recursos em seu caixa e os investidores terão acesso a um investimento de baixo risco, com garantia dos recebíveis e não se submetendo ao risco da empresa emissora da debênture.

Essa estrutura possibilita que as empresas utilizem seu contas a receber como um instrumento de captação de recursos e à medida que a empresa tem acesso a esse capital, sem elevar os seus passivos onerosos, estará gerando recursos para seu financiamento, sem utilizar seu limite de crédito disponível junto aos bancos ou aumentar seu nível de endividamento. 
Diante do exposto, conforme Oda (2004, p. 14), os trabalhos sobre estrutura de capital demonstram que à medida que as dívidas aumentam, os ganhos dos acionistas tornam-se mais voláteis. O endividamento pode ser usado como uma medida de risco criado pela estrutura de capital da empresa e, conseqüentemente, a classificação do rating de crédito pode sofrer alterações negativas em relação ao status quo da empresa.

O tema do presente trabalho pode ser de amplo interesse à comunidade financeira e atende aos investidores do mercado de capitais, e, também, aos gestores financeiros das empresas. Tendo em vista que a alavancagem financeira multiplica o risco implícito em um negócio, a securitização de ativos pode ser uma alternativa para a redução dessa alavancagem financeira e, conseqüentemente, a redução do risco da empresa, mensurado pelo seu beta de mercado das ações.

\section{5 - Descrição dos Capítulos}

Essa tese está organizada em seis capítulos. O primeiro descreve e justifica o tema e o objetivo do trabalho. A seguir, a Fundamentação Teórica apresenta o corpo conceitual que sustenta o desenvolvimento da pesquisa e traz uma revisão da literatura sobre o tema abordado, destacando os principais testes empíricos já realizados. O terceiro capítulo descreve a Metodologia dos Ratings de Crédito utilizada pelas principais agências de classificação de rating de crédito que atuam no Brasil. O capítulo 4 demonstra a Metodologia da Pesquisa, justifica a amostra e o período escolhidos para a realização do estudo e trata os métodos e instrumentos empregados na coleta e análise dos dados, bem como de suas limitações. O Capítulo 5 apresenta a Análise e Discussão dos Resultados e o Capítulo 6 expõe as Considerações Finais, acompanhadas de recomendações de estudos futuros. 


\section{CAPÍTULO 2 - ESTRUTURA DA SECURITIZAÇÃO DE ATIVOS}

"Securitization is one of the most important innovations of modern finance".

J.David Cummins (The Wharton School)

No final dos anos de 1970, o mercado de bonds de empresas corporativas nos EUA presenciou a introdução de operações estruturadas, nas quais o risco de crédito da emissão desses títulos não era mais baseado no risco de crédito do emissor, ou seja, da empresa responsável pela emissão.

Os títulos (bonds) lançados nessa nova estrutura eram representados por um conjunto de recebíveis, especificamente originados por operações de empréstimos ou financiamentos, sendo que o fluxo de caixa dos títulos (bonds) correspondia exatamente ao fluxo de caixa dos recebíveis. Esse tipo de estrutura ficou conhecida nos EUA como Asset-Backed Securities (securitização de ativos).

Conforme Kothari (1999, p. 68), a primeira operação de securitização da história dos EUA foi realizada, no ano de 1970, como uma operação de securitização de ativos imobiliários (mortgage backed securities). Essa operação foi realizada pela Government National Mortgage Association, mais conhecida como Gennie Mae, empresa estatal criada especialmente para desenvolver o mercado secundário de hipotecas do setor de imóveis.

Fabozzi (2000, p.138) destaca que para os governos poderem intervir em prol do desenvolvimento do setor imobiliário residencial é necessário o reconhecimento de três grupos distintos participantes desse mercado:

aqueles que necessitam do financiamento imobiliário para a aquisição dos imóveis: os adquirentes;

aqueles que fornecem recursos para investimentos e financiamentos imobiliários e produtos correlatos: os investidores;

aqueles que desenvolvem e produzem o bem imobiliário: os empreendedores e construtores. 
Nesse sentido, o governo dos EUA, por meio da criação de agências governamentais ou entidades de economia mista influenciou efetivamente 0 comportamento dos três grupos citados, por meio da implantação de mecanismos de apoio:

fornecendo seguro ou garantia para os créditos imobiliários contra riscos de inadimplência;

desenvolvendo produtos financeiros atrativos tanto aos tomadores de recursos (adquirentes) quanto aos investidores;

criando padrões de originação de créditos imobiliários, incluindo contratos, documentação e prazos;

proporcionando liquidez ao mercado secundário, por meio da compra de créditos imobiliários e

subsidiando construções de moradias específicas à classe de baixa renda.

Conforme Brealey e Myers (2003, p. 273), ao invés de fazer empréstimos bancários, as empresas acumulam um grupo de ativos e depois vendem os fluxos de caixas desses ativos. Uma sociedade compra esses ativos e realiza a emissão de títulos. Esses títulos são conhecidos como ativos securitizados ou asset backed securities.

Por exemplo, em 1992, a Chrysler Motor Companie utilizou-se de uma estrutura de Asset Backed Securities, após passar por um Dow Grade do seu Rating de Crédito, ou seja, foi reduzido para $B+$. Outro exemplo foi uma operação estruturada pelo Banco Goldman Sachs para o Rockefeller Center, resultando na emissão de títulos no valor de 1,2 bilhões de dólares americanos, em que o recebível dessa operação foi a hipoteca do complexo de edifícios localizados em Manhattan. O risco dessa securitização foi classificado pelas agências de rating de crédito da época como rating "AAA" (a melhor classificação de risco possível).

Um outro exemplo de operação de asset-backed-securities aconteceu na Inglaterra, em 1977, quando David Bowie, um astro de rock britânico, estabeleceu uma empresa que comprava os royalties de seus álbuns atuais. A empresa financiou a compra desses royalties com a venda de $\$ 55$ milhões em notas de 10 anos a uma 
taxa de juros de $7,9 \%$ ao ano. Os recibos de royalties foram usados para fazer os pagamentos dos juros e do principal sobre as notas.

Mais recentemente, em 2002, o estúdio do diretor de cinema Steven Spielberg, lançou um fundo de investimentos chamado DW Funding LLC, atraindo vários investidores. Tal fundo possuia direitos creditórios das bilheterias e publicidade de diversos filmes consagrados desse diretor.

Atualmente, os instrumentos de securitização de ativos nas suas mais diversas formas, ABS - asset backed securities, MBS - mortgage backed securities e CDO colateralized debt obligation, que é um conjunto de obrigações de dívida, garantido por um conjunto diversificado de ativos, representam as operações realizadas no mercado americano e se destacam como o maior mercado de securitização mundial, conforme demonstrado nos dados da tabela a seguir.

Tabela 1 - Volume Anual Total de Securitização nos EUA

\begin{tabular}{|l|r|r|}
\hline & \multicolumn{1}{|c|}{$\begin{array}{c}2006 \\
\text { Issuance } \\
(\$ M i l .)\end{array}$} & $\begin{array}{c}\text { 2005 } \\
\text { Issuance } \\
\text { (\$Mil.) }\end{array}$ \\
\hline U.S. Public ABS & $\$ 543,597.6$ & $\$ 566,592.3$ \\
\hline U.S. Rule-144A ABS & $109,152.5$ & $60,059.9$ \\
\hline U.S. Public MBS & $417,782.5$ & $395,299.7$ \\
\hline U.S. Private ABS & 0.0 & $3,300.0$ \\
\hline Non-U.S. ABS and MBS & $255,195.9$ & $163,006.2$ \\
\hline U.S. Commercial MBS & $138,288.8$ & $114,516.4$ \\
\hline Non-U.S. Commercial MBS & $59,992.2$ & $50,036.4$ \\
\hline Worldwide CDOs & $298,520.2$ & $150,611.3$ \\
\hline Worldwide Total & $\mathbf{1 , 8 2 2 , 5 2 9 . 6}$ & $\mathbf{1 , 5 0 5 , 4 2 2 . 2}$ \\
\hline
\end{tabular}

Fonte: Asset-Backed Alert (2006)

O povo americano possui uma cultura tradicional de contrair dívidas de longo prazo, conforme destaca Saunders (1997, p. 58), bem como uma característica de comprar casas novas em vez de reformar, gerando uma considerável demanda por imóveis novos. 
De acordo com Vedrossi (2002, p. 79), pode-se somar a esse aspecto cultural, as seguintes questões referentes aos ambientes fiscal, regulatório e jurídico, que possuem uma participação importante nesse processo de aquisição imobiliária:

Contínuo estímulo para aquisição de imóveis, pois os juros pagos nas prestações são dedutíveis do imposto de renda;

A legislação aplicada ao setor imobiliário permite a rápida recuperação dos imóveis, nos casos de inadimplência dos mutuários;

Existência de farto banco de dados a respeito do histórico de pagamentos e inadimplência, facilitando a avaliação do risco de crédito das carteiras hipotecárias.

A associação desses fatores impulsionou e transformou o mercado americano de securitização de ativos imobiliários (mortgage backed securities) no mercado mais ativo e desenvolvido em todo o mundo. Conforme a FNMA - Federal National Mortgage Association (2006, p. 1), conhecida como Fannie Mae, empresa privada, que possui a função de comprar e vender hipotecas, estima-se que o volume total de emissão de títulos lastreados em hipotecas nos EUA atingiu, aproximadamente, US\$ 560 bilhões de dólares americanos (outstanding até setembro de 2006).

De acordo com Rabbat (2002, p. 3), os principais tipos de ativos securitizados nos EUA nas décadas de 1980 e 1990 foram:

Mortgages (hipotecas de imóveis);

Empréstimos de automóveis;

Empréstimos comerciais;

Recebíveis de cartão de crédito e

Empréstimos concedidos a países emergentes - Junk bonds (títulos de renda fixa com risco especulativo).

Ao longo das três últimas décadas, o uso das operações de asset backed securitiesABS e mortgage backed securities - MBS tem crescido rapidamente nos EUA, conforme demonstrado no gráfico 1 do balanço anual de hipotecas securitizadas, ou 
seja, o estoque (volume acumulado) de hipotecas securitizadas no mercado americano.

\section{Gráfico 1 - Balanço Anual de Hipotecas Securitizadas}

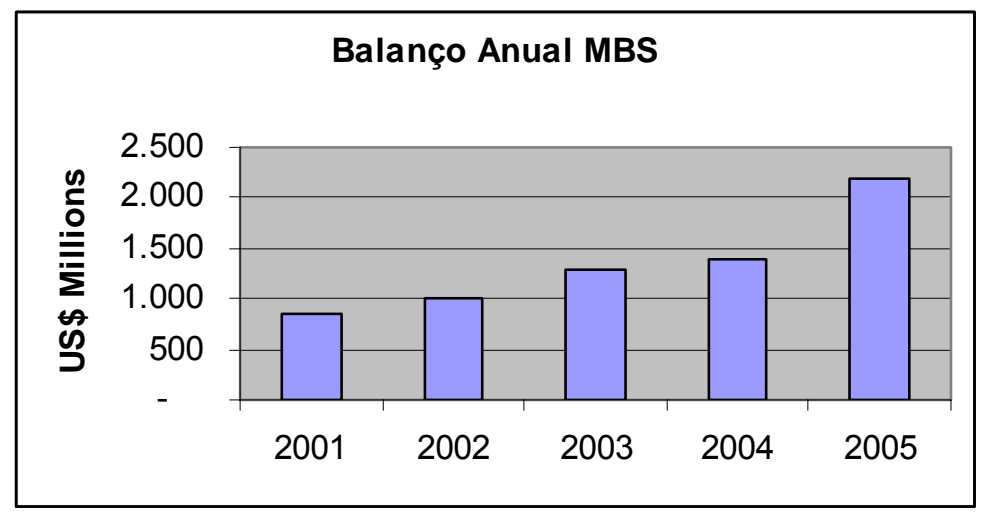

Fonte: FNMA (2006)

Segundo Kothari (1999, p. 145), o Reino Unido destaca-se como o mercado mais expressivo em relação às operações de securitização em toda a Europa incluindo, nessa estatística, as operações que envolvem recebíveis imobiliários, conforme demonstrado no gráfico a seguir.

Gráfico 2 - Ranking das operações de securitização fora dos EUA

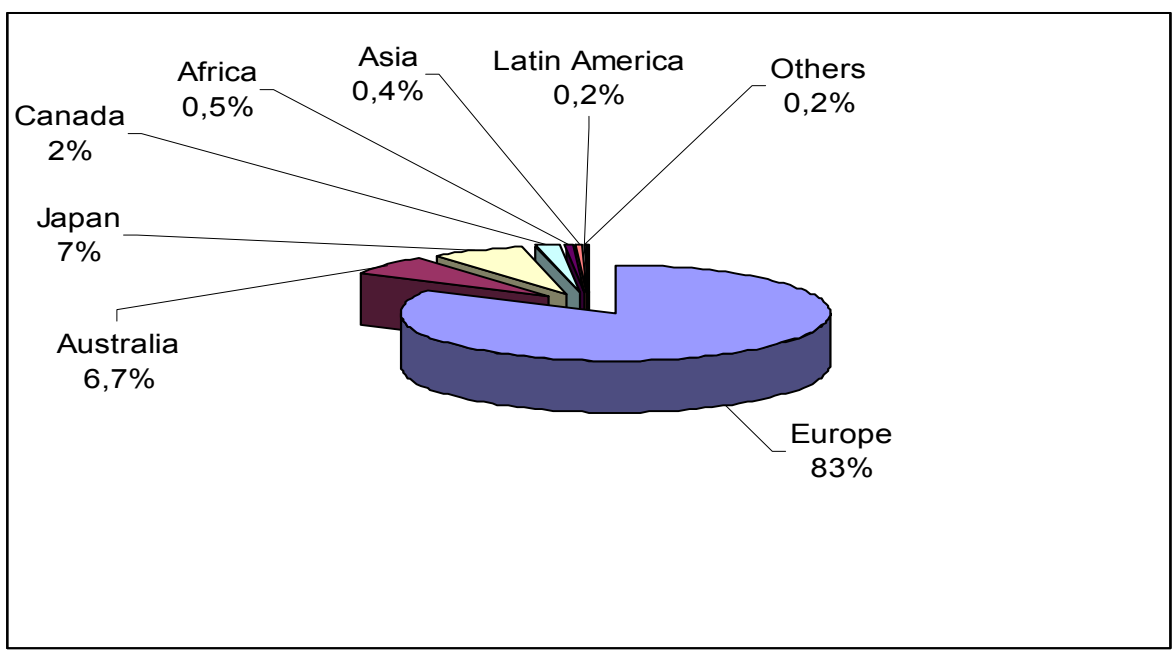

Fonte: Asset-Backed Alert (2006) 
No Brasil, as primeiras operações de securitização realizadas ocorreram na década de 1970, ou seja, o conceito de enhancement (fortalecimento ou reforço) de crédito começava a se propagar de forma limitada. Esse enhancement era realizado por meio de lançamento de títulos, ou seja, o principio básico envolvia a emissão do titulo e valor mobiliário pela própria sociedade comercial originadora dos créditos (recebíveis). Nessa modalidade, conhecida como securitização parcial, a sociedade comercial emitia no mercado de capitais, títulos e valores mobiliários. Em principio, eram debêntures com garantia real, por meio do penhor de direitos creditórios. Para a garantia do pagamento das debêntures eram dadas essas garantias do instrumento de penhor. São exemplos dessa operação as emissões de títulos que as empresas administradoras de cartões de crédito faziam, com a garantia dos recebíveis dos titulares dos cartões de crédito.

Contudo, essa forma de securitização, não se preocupava em segregar o ativo em questão dos demais ativos do originador, e, conseqüentemente, os investidores estariam assumindo o risco de falência da originadora dos recebíveis.

No início dos anos 1990, surgiu o conceito de segregação de ativos do originador por meio da cessão de direitos creditórios, ou seja, uma venda efetiva dos recebíveis, dando origem à estrutura de securitização de ativos utilizada atualmente.

De acordo com Dermine e Bissada (2005, p. 62), "a expressão securitização (securitization) tem por origem a palavra securities, que significa títulos. A securitização é um processo de acordo com o qual empréstimos se transformam em lastro para a emissão de valores mobiliários ou títulos". O lastro de um título corresponde ao ativo ao qual este título está vinculado.

Nesse tipo de operação, não ocorrendo a segregação dos direitos creditórios do patrimônio da empresa originadora, o investidor estará exposto ao risco de falência ou recuperação extra-judicial (antiga concordata) dessa empresa originadora. Essa operação é conhecida como securitização parcial.

Algumas operações com essas características foram também realizadas nos anos de 1970, ainda que de forma pontuais, especialmente por empresas prestadoras de serviços públicos, tais como: fornecimento de energia elétrica, serviço de telefonia e água. Nessas operações, somava-se ao penhor de direitos creditórios a opção dada 
ao investidor (comprador do título e valor mobiliário), a utilização do valor do seu crédito para o pagamento pelo serviço público prestado, em caso do não recebimento do título e valor mobiliário adquirido.

A securitização parcial não utiliza a SPE - Sociedade de Propósito Específico como veículo de segregação do risco inerente às atividades da sociedade emissora dos títulos e valores mobiliários. Conseqüentemente, os investidores, ao adquirirem os títulos e valores mobiliários emitidos, correm o risco de crédito da sociedade emissora do título e valor mobiliário.

Na securitização efetiva, ou seja, com a segregação do risco de crédito da empresa originadora, há uma transferência dos direitos creditórios gerados pela empresa originadora para uma SPE - Sociedade de Propósito Específico, utilizada como instrumento e veículo da operação, a qual realiza uma emissão pública de títulos e valores mobiliários, aplicando o produto dessa emissão na aquisição dos direitos creditórios originados pela sociedade originadora dos recebíveis.

Para dar segurança aos investidores, o valor total das emissões das debêntures deverá obedecer a determinados limites legais (quando a debênture emitida for subordinada não há qualquer obrigatoriedade de se atender ao requisito referido no artigo 60, da Lei $n^{\circ}$ 6404/76). O valor dos direitos creditórios dados em garantia real (recebíveis), por exigência legal, deve ser superior ao valor das debêntures emitidas, e produzir uma margem de segurança que sustentará uma eventual inadimplência da carteira dos créditos (recebíveis).

De acordo com Gaggini (2003, p. 19):

"consiste a securitização de recebíveis em uma operação na qual uma empresa, que chamaremos de originadora, transfere créditos seus para uma outra empresa, que chamaremos de securitizadora, constituída especificamente para a execução deste projeto. Essa empresa adquirirá os créditos da originadora e, tendo-os por lastro, emitira títulos e valores mobiliários, que serão ofertados publicamente no mercado de capitais. Com os recursos obtidos por meio dessa oferta pública de títulos e valores mobiliários, a securitizadora pagará a originadora pelos créditos a ela cedidos". 
A securitização efetiva deve propiciar a máxima segurança aos investidores, pois, ao invés desses adquirirem um valor mobiliário de emissão da sociedade originadora, correndo os riscos de crédito inerentes a essa pessoa jurídica, o título mobiliário adquirido será de emissão de uma SPE - Sociedade de Propósito Específico, que terá a finalidade específica de emissão do título e valor mobiliário e aquisição de direitos creditórios da sociedade comercial. O risco de crédito dos investidores se limitará à qualidade dos créditos de que a SPE é titular.

\section{1 - Financiamento do Capital de Giro}

O financiamento do capital de giro envolve um processo contínuo de tomada de decisões voltadas, principalmente, para a preservação da liquidez da empresa, que por sua vez, também afeta a rentabilidade.

De acordo com Sousa e Menezes (1997, p. 31), "os recursos financeiros à disposição da empresa são aplicados em ativos classificados genericamente como circulantes". Logo, a administração do capital de giro se ocupa principalmente dos ativos e dos passivos circulantes. Ativos circulantes são aqueles representados, basicamente, pelas disponibilidades financeiras, estoques e contas a receber. Passivos circulantes são aqueles compreendidos pelas obrigações de curto prazo.

As necessidades de capital de giro são as demandas de recursos financeiros que a empresa possui, no sentido de viabilizar suas operações normais e também ter assegurado um excedente de caixa suficiente para a segurança estabelecida pela direção da empresa. Essas necessidades de capital de giro são satisfeitas por recursos próprios e/ou recursos de terceiros, também chamados comumente de "cobertura do capital de giro".

Nesse sentido, de acordo com Ross et al. (1995, p. 298), "as empresas, de maneira geral, necessitam de financiamento para gastos de investimento, capital de giro e outras aplicações de longo prazo". 
Conforme Weston e Brigham (2000, p. 378), o capital de giro é o investimento de uma empresa em ativos de curto prazo, por meio de caixa, títulos negociáveis, estoques e contas a receber.

Conforme BID (2004, p. 5), a estabilidade do processo de oferta de crédito é fundamental para o desenvolvimento. Os projetos, de uma maneira geral, exigem acesso contínuo a fontes de financiamentos e uma interrupção na oferta de crédito pode levar à ruptura do investimento e do crescimento da economia.

O conceito de capital de giro, conforme explica Sousa et al. (1996, p.1), costuma apresentar diferentes interpretações, desde representar o valor total dos recursos demandados pela empresa para financiar o seu ciclo operacional, ou até no processo de planejamento, controle do nível e da composição dos ativos e passivos circulantes da empresa.

O objetivo principal da administração do capital de giro é administrar individualmente os ativos e passivos circulantes da empresa, de forma a manter um nível aceitável de capital circulante líquido.

Weston e Brigham (2000, p. 209) indicam três fatores que caracterizam a importância do capital de giro:

o tempo dedicado à administração do capital de giro;

o investimento em ativos circulantes (por exemplo, estoques);

a relação entre o crescimento de vendas e os ativos circulantes.

Logo, toda empresa possui uma política de capital de giro que procurará definir como financiar os ativos circulantes, haja vista estar relacionado diretamente com o ciclo operacional e com o giro dos negócios.

A sustentação da atividade operacional das empresas é mantida pela manutenção de determinados volumes de recursos aplicados no capital de giro, garantido a liquidez necessária. De acordo com Fama e Grava (2000, p. 2), a análise da liquidez das empresas passa pela compreensão de seus ativos e passivos de curto prazo. 
Conforme Assaf (2002, p. 190), o financiamento do capital de giro constitui-se no fundamento básico da avaliação do equilíbrio financeiro de uma empresa. Pela análise de seus elementos patrimoniais são identificados os prazos operacionais, o volume de recursos permanentes (longo prazo) que se encontra financiando o giro e as necessidades de investimento operacional.

Resumidamente, pode-se dizer que, em função da não sincronização entre produção, vendas e cobrança surge a necessidade do gerenciamento de capital de giro. Esse gerenciamento deverá requerer a obtenção de financiamento junto às instituições financeiras.

Por meio das instituições financeiras bancárias é que o planejamento de curto e longo prazos é executado na rotina diária das empresas.

Conforme destaca Sousa e Menezes (1997, p.1), o planejamento de longo prazo estabelece condições para decisões sobre investimentos de capital das empresas e uma estrutura de capital mais adequada ao tipo da empresa. Já, o planejamento de curto prazo deve produzir resultados que refletirão a saúde financeira da empresa, pois, tal planejamento é focado em ativos e passivos circulantes. Com isso, o processo de planejamento financeiro é uma grande fonte de contribuição para o sucesso organizacional.

As atividades de intermediação financeira passaram por uma grande transformação ocasionada pela moratória mexicana de 1982, isto é, a moratória decretada pelo México provocou uma mudança fundamental na gestão de crédito, possibilitando o acesso das corporações a recursos em forma de dívida corporativa.

A partir desse marco, uma série de operações não convencionais, conhecidas no mercado financeiro como operações estruturadas, passaram a ser realizadas permitindo, em um momento inicial, que as grandes corporações dos EUA financiassem seus projetos por meio da emissão de títulos de dívida corporativa, evitando dessa forma, o acesso ao crédito tradicional.

Logo, a necessidade de recursos para capital de giro ou compra de estoques pode ser obtida por duas formas de financiamento: Right Hand Side - RHS ou Left Hand 
Side - LHS, ou seja, o lado direito e o lado esquerdo do balanço patrimonial das empresas.

Os recursos obtidos pelo método RHS incluem os instrumentos de dívida (recursos de terceiros) ou aporte de capital (recursos próprios). Em contraste a essa forma, o método LHS busca obter recursos fixando-se na venda dos fluxos de caixa a receber, incluindo-se operações de leasing, factoring e, também, a securitização de ativos.

\section{2 - Fontes Tradicionais de Financiamento do Capital de Giro}

Existem diversas formas de financiamento do capital de giro, desde as mais tradicionais como os empréstimos bancários tanto de curto prazo quanto de longo prazo como, também, as emissões de títulos de dívida no chamado mercado de capitais e os financiamentos estruturados como o project finance e a securitização de ativos.

$\mathrm{Na}$ modalidade de empréstimo tradicional existe a figura central do financiador, caracterizada por uma instituição financeira que, realiza a captação de recursos de investidores e posteriormente, repassa esses recursos aos tomadores de empréstimos, que via de regra são as empresas.

Para melhor entendimento de cada alternativa de empréstimos utilizados pelas empresas, segue uma síntese de cada produto.

Empréstimos bancários de curto prazo:

Os tipos de empréstimos bancários, conforme o quadro a seguir, caracterizam-se pelo prazo de até um ano, comumente conhecidos como empréstimos de curto prazo. 


\section{Quadro 2 - Principais produtos de empréstimos e suas características}

\begin{tabular}{|c|c|}
\hline Tipo de Empréstimo & Principais Características \\
\hline Hot money & $\begin{array}{l}\text { Operação caracterizada por um empréstimo de curtíssimo prazo } \\
\text { (dinheiro rápido), normalmente contratado pelo prazo de } 1 \text { a } 10 \\
\text { dias, que as empresas tomam para suprir uma eventual } \\
\text { necessidade de caixa inesperada. Essa forma de empréstimo } \\
\text { possui um custo elevado, caso seja considerado o efeito da } \\
\text { CPMF-Contribuição Provisória sobre Movimentação Financeira. }\end{array}$ \\
\hline Capital de Giro (KG) & $\begin{array}{l}\text { Operações que visam a atender às necessidades de capital de } \\
\text { giro (NCG+) das empresas, representadas por empréstimos } \\
\text { vinculados a um contrato em que se estabelecem o prazo, } \\
\text { geralmente entre } 30 \text { e } 180 \text { dias, com taxas prefixadas e/ou } \\
\text { indexadas ao CDI, em que o principal e encargos serão } \\
\text { amortizados no vencimento. Esse tipo de empréstimo pode } \\
\text { possuir garantias exigidas pelos bancos. }\end{array}$ \\
\hline Conta Garantida & $\begin{array}{l}\text { Contrato de abertura de crédito rotativo no qual é aberta uma } \\
\text { conta de crédito a favor do cliente, destinando-se um limite que } \\
\text { pode ser livremente movimentado. Dessa forma, a conta } \\
\text { garantida passou a ser entendida como a que garante ao cliente } \\
\text { o acesso aos recursos estabelecidos por limite contratual, à } \\
\text { medida que deles necessita. Geralmente as instituições } \\
\text { bancárias exigem garantias, por meio de caução de duplicatas } \\
\text { e/ou notas promissórias. }\end{array}$ \\
\hline Desconto Duplicatas & $\begin{array}{l}\text { Operação pela qual a instituição financeira adianta ao cliente } \\
\text { recursos referentes a valores de duplicatas geradas em vendas } \\
\text { mercantis, recebendo como garantia essas duplicatas. O banco, } \\
\text { via de regra, baseia-se na qualidade do risco de crédito do } \\
\text { sacado da duplicata, para estabelecer a taxa de desconto. }\end{array}$ \\
\hline Vendor Finance & $\begin{array}{l}\text { De acordo com Ortolani (1999: p.95), conceito introduzido no } \\
\text { mercado financeiro brasileiro no início dos anos } 80 \text {. O vendor é } \\
\text { um programa de financiamento de vendas por meio do qual } \\
\text { clientes do banco, geralmente fornecedores de bens em geral, } \\
\text { utilizam a obtenção de recursos diretos do banco para seus } \\
\text { compradores - clientes, permitindo a esses pagar à vista pelas } \\
\text { compras efetuadas. A base de risco da operação para o banco é } \\
\text { o fornecedor (vendedor), que se compromete pelo cumprimento } \\
\text { das obrigações dos compradores perante o banco, concedendo- } \\
\text { lhes a fiança como garantia do empréstimo. }\end{array}$ \\
\hline ACC & $\begin{array}{l}\text { O adiantamento sobre contrato de câmbio, conhecido } \\
\text { comumente como ACC, é uma forma de antecipação de receita } \\
\text { direcionada a exportadores de bens ou serviços, que já tenham } \\
\text { fechado o contrato de venda de exportação e possuam uma data } \\
\text { prevista para o embarque das mercadorias e posterior ingresso } \\
\text { das divisas (moeda estrangeira). O contrato de câmbio, que } \\
\text { envolve o ingresso futuro de moeda estrangeira, será negociado } \\
\text { com um banco local, que adianta ao exportador os reais } \\
\text { equivalentes ao valor da exportação, mediante uma taxa de } \\
\text { desconto, que é via de regra a LIBOR - London Interbank } \\
\text { Offered Rate, acrescida do spread do banco que realizará o ACC. }\end{array}$ \\
\hline
\end{tabular}




\begin{tabular}{|l|l|}
\hline ACE & $\begin{array}{l}\text { O adiantamento sobre cambiais entregues, conhecido como } \\
\text { ACE, é idêntico ao ACC, porém, esse adiantamento é exclusivo } \\
\text { para as exportadoras que já embarcaram a mercadoria, ou seja, } \\
\text { é o adiantamento pós-embarque. }\end{array}$ \\
\hline Commercial Paper & $\begin{array}{l}\text { O commercial paper ou nota promissória comercial é um título de } \\
\text { crédito emitido exclusivamente por empresas de sociedade por } \\
\text { ações não financeiras, ou seja, empresas S/A. O commercial } \\
\text { paper é um título emitido e negociado no mercado de capitais, } \\
\text { possuindo prazo de vencimento entre 30 e 360 dias, podendo ser } \\
\text { pré-fixado ou pós-fixado (indexado à taxa do CDI-Cetip), } \\
\text { geralmente adquirido pelos investidores institucionais, ou seja, os } \\
\text { fundos de pensão, fundos de investimentos e seguradoras. }\end{array}$ \\
\hline
\end{tabular}

Fonte: Elaborado pelo Autor

Empréstimos bancários e financiamentos de longo prazo:

Os tipos de empréstimos e financiamentos, conforme o quadro a seguir, caracterizam-se pelo prazo acima de um ano, conhecidos como financiamentos de longo prazo.

\section{Quadro 3 - Tipos e Principais Características das Operações de} Financiamentos

\begin{tabular}{|l|l|}
\hline Tipo de Operação & Principais Características \\
\hline \multirow{5}{*}{ Leasing Financeiro } & $\begin{array}{l}\text { O leasing é uma operação de arrendamento mercantil, ou seja, } \\
\text { aluguel de bens duráveis (máquinas, equipamentos, caminhões, } \\
\text { veículos, motocicletas e equipamentos de informática), com } \\
\text { prazo mínimo de vencimento de } 24 \text { meses. É uma operação } \\
\text { realizada entre o arrendador (empresa de leasing) e o } \\
\text { arrendatário (empresa), pela qual o primeiro concede ao segundo } \\
\text { a utilização de um bem, por prazo determinado, mediante } \\
\text { pagamento de um aluguel e, em geral, com opção de compra do } \\
\text { bem em questão ao final do contrato, por meio do VRG-Valor } \\
\text { Residual Garantido. O VRG é o valor pelo qual o arrendatário } \\
\text { (empresa) se compromete a comprar o equipamento no final do } \\
\text { contrato de arrendamento. Leasing é o aluguel de um bem por } \\
\text { determinado período. Após tal período, a empresa usuária } \\
\text { poderá ou não adquirir a propriedade desse bem, por um } \\
\text { determinado preço, estabelecido em contrato. }\end{array}$ \\
\hline
\end{tabular}




\begin{tabular}{|c|c|}
\hline Resolução 63 & $\begin{array}{l}\text { A Resolução } n^{\circ} 63 \text {, de } 21 / 08 / 67 \text {, do } C M N \text { - Conselho Monetário } \\
\text { Nacional, revogada pela Resolução } n^{\circ} 2770 \text {, de } 0 / 08 / 00 \text { e a } \\
\text { Circular } n^{\circ} 3.027 \text { com seu regulamento anexo, de } 22 / 02 / 01 \text {, } \\
\text { consolidam todas as normas que disciplinam as operações de } \\
\text { empréstimos entre os residentes e domiciliados no País e os } \\
\text { residentes e domiciliados no exterior. Logo, os recursos externos } \\
\text { captados pelas instituições financeiras podem ser repassados, } \\
\text { mediante empréstimos em moeda estrangeira, às empresas no } \\
\text { País. }\end{array}$ \\
\hline Debêntures & $\begin{array}{l}\text { As debêntures são títulos de dívida emitidos exclusivamente por } \\
\text { sociedades por ações não financeiras, ou seja, empresas S/A, no } \\
\text { mercado de capitais, para obtenção de recursos de longo prazo, } \\
\text { geralmente acima de } 12 \text { meses, destinados normalmente a } \\
\text { financiamento de projetos de investimentos ou com o objetivo de } \\
\text { alongamento do perfil da estrutura de capital da empresa S/A. Os } \\
\text { compradores das debêntures são investidores institucionais } \\
\text { (fundos de pensão e seguradoras) que esperam receber juros } \\
\text { periódicos e reembolso do principal na data do vencimento da } \\
\text { debênture. }\end{array}$ \\
\hline Project Finance & $\begin{array}{l}\text { O project finance ou financimento de projetos é uma operação } \\
\text { financeira estruturada que permite às empresas } \\
\text { empreendedoras, também conhecidas na literatura internacional } \\
\text { como sponsor, obter recursos de longo prazo, para o } \\
\text { financiamento de projetos de implantação de unidades ligadas } \\
\text { geralmente à infra-estrutura e bens de capital. A vantagem do } \\
\text { project finance é a ruptura do modelo tradicional centrado na } \\
\text { empresa empreendedora que busca financiamento para a } \\
\text { implantação de um projeto próprio e a adoção de um conceito } \\
\text { mais amplo, ou seja, o do empreendimento (projeto) com vários } \\
\text { participantes, em que a estrutura ou engenharia financeira desse } \\
\text { tipo de operação permitirá o compartilhamento do risco e retorno } \\
\text { entre os diversos participantes. }\end{array}$ \\
\hline
\end{tabular}

Fonte: Elaborado pelo Autor

De acordo com os dados do Banco Central do Brasil, de 2006, seguem conforme o gráfico a seguir, as principais operações de empréstimos de curto prazo e longo prazos realizadas pelas instituições financeiras bancárias, junto às empresas. 


\section{Gráfico 3 - Ranking das Operações de Empréstimos e Financiamentos}

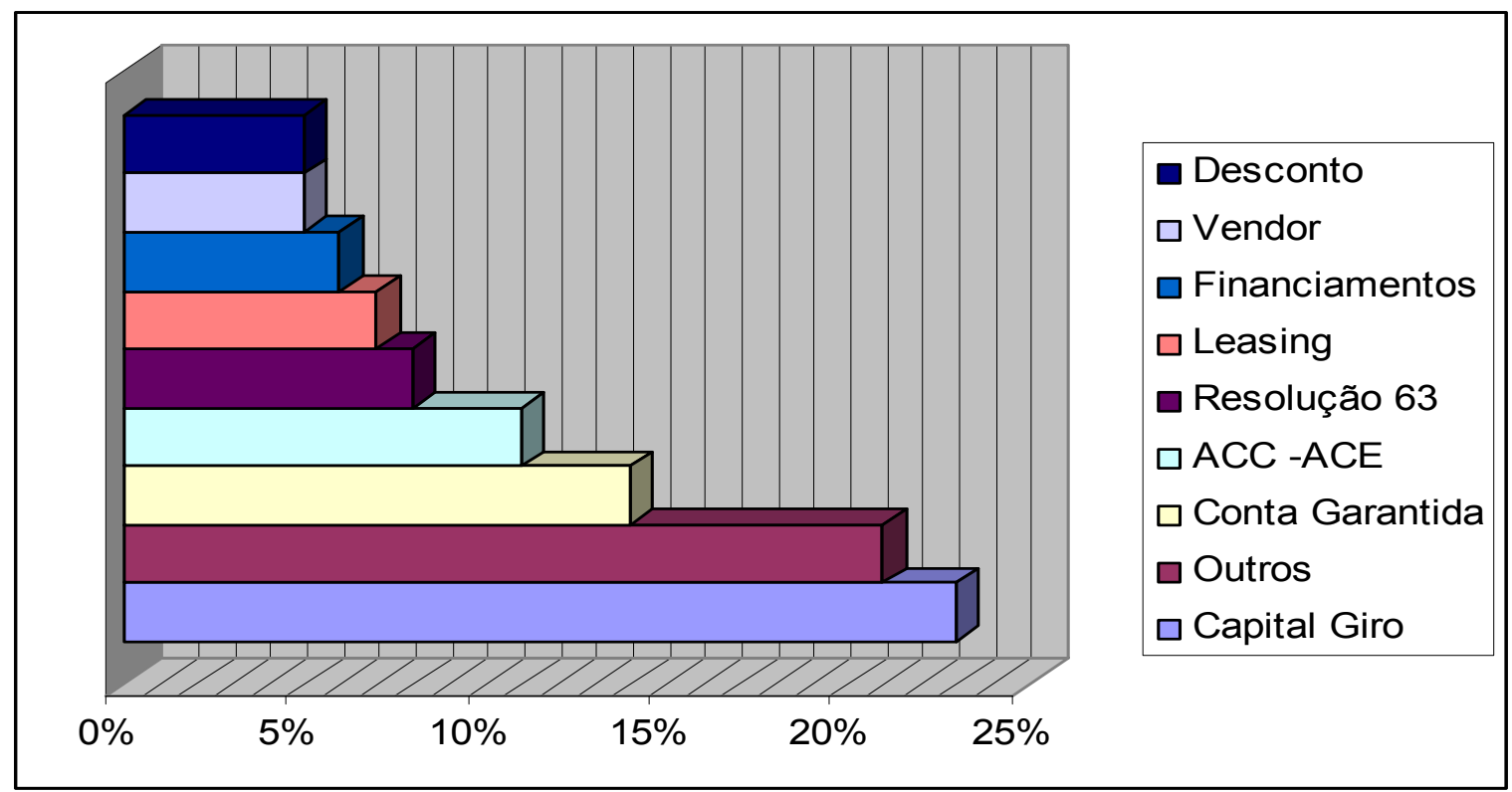

Fonte: Banco Central do Brasil (2006)

As taxas praticadas pelos bancos, nessas formas de financiamentos tradicionais, são estabelecidas, de acordo com o risco de crédito do tomador e, muitas vezes, requerem garantias, em função do risco de crédito oferecido.

Risco de crédito, em termos gerais, refere-se ao risco de perda decorrente da inabilidade do emitente e do devedor em cumprir as suas obrigações. Acredita-se que no Código de Hamurabi de, $1800 \mathrm{AC}$, se previam seções relativas à regulamentação do crédito na antiga Babilônia. Por isso, o risco de crédito é tão antigo quanto os próprios empréstimos e financiamentos.

De acordo com Securato (2002, p. 17), "o termo crédito estabelece uma relação de confiança entre duas (ou mais) partes em determinada operação".

Desse modo, segundo Altman et al. (2000, p.1), o risco de crédito é a mais antiga forma de risco nos mercados financeiros. Caso o crédito possa ser definido como a expectativa de receber uma certa quantia em dinheiro dentro de um intervalo de tempo limitado, o risco de crédito será a probabilidade dessa expectativa não se realizar. 
De acordo com Altman et al. (2000, p. 3), o risco de crédito é conseqüência de uma transação financeira contratada e/ou contigencial entre um fornecedor de recursos e uma empresa captadora desses recursos.

Para calcular o risco de crédito do emitente geralmente são considerados:

Probabilidade de inadimplência: A probabilidade de o devedor não cumprir as suas obrigações contratuais para honrar os seus débitos.

Taxa de recuperação: A probabilidade de que um valor nominal possa ser recuperado uma vez que o devedor esteja inadimplente.

Migração do crédito: Sem evento de inadimplência, a probabilidade da qualidade do devedor do recebível em melhorar ou piorar é representada por uma mudança na probabilidade desse devedor tornar-se inadimplente.

As taxas de juros cobradas nos empréstimos, de maneira geral, dependem da qualidade do risco de crédito do tomador. Segundo Saunders (2000, p.8), os especialistas analisam os cincos "Cs" do crédito, ou seja, caráter, capital, capacidade, collateral e condições econômicas, atribuindo para cada um dos cinco fatores-chave um peso subjetivamente, chegando-se a uma decisão de crédito.

Surge, assim, um grande desafio para os administradores financeiros: encontrar meios ou instrumentos de obtenção de crédito ou de financiamento, oferecendo maiores garantias e desvinculando o risco de crédito da empresa, de forma a se obter recursos com custos menores.

De acordo com Stewart (1990, p. 354), "um instrumento de financiamento criará valor quando for capaz de propiciar":

menor carga tributária;

redução de custos de transação e

diminuição do risco de falência. 
A fim de resolver tais desafios, os mercados de capitais buscam, constantemente, o desenvolvimento das chamadas inovações financeiras e, dentre elas, pode-se identificar a criação da operação de securitização de recebíveis, que surge como uma alternativa de financiamento do capital de giro das empresas.

\section{3 - Principais Aspectos e Características de Securitização}

Os bancos, de acordo com Dermine e Bissada (2005, p.62), "têm desenvolvido, nos últimos anos, técnicas para vender empréstimos aos investidores. Esse mecanismo é chamado de securitização".

Segundo o mesmo autor, a expressão securitização (securitization) tem por origem a palavra securities, que possui o significado de títulos. O termo security é definido em cinco leis federais norte-americanas, conforme descrição a seguir, compreendendo toda nota, ação, ação em tesouraria, obrigação, debênture, opções e vários outros tipos de títulos e certificados:

Securities Act de 1933;

Securities Exchange Act de 1934;

Public Utility Holding Company Act de 1935;

Investment Company Act de 1940;

Investment Advisers Act de 1940.

Elaborando um paralelo com o Brasil, o termo security utilizado nos EUA, em uma visão geral, possui o significado de valor mobiliário que, de acordo com o ordenamento jurídico por meio da edição da Lei do Conselho Monetário Nacional $n^{\circ}$ 10.303, de 2001:

Artigo $2^{\circ}$ "são valores mobiliários as ações, debêntures, bônus de subscrição, recibos de subscrição, as cédulas de debêntures, as notas comerciais, os contratos futuros, de opções e outros derivativos, as cotas de fundos de investimento e demais outros títulos". 
Conforme Gaggini (2003, p. 27), na França, as operações de securitização de ativos são denominadas titrisation, tendo sido praticadas desde o início da década de 80, do século XX, e o órgão fiscalizador dessa espécie de operação é a Commission des Operations de Bourse. As instituições financeiras francesas utilizam esse tipo de operação como meio eficaz de saneamento e melhoria de qualidade das carteiras de crédito. São utilizados como securitizadoras os fundos de investimento (fonds communs de créances) e as sociedades gestoras de fundos. A esse respeito menciona Matias (1998, p. 32):

\begin{abstract}
"A tritisation opera-se pela transferência do crédito para o fundo comum. $\mathrm{O}$ conjunto dos créditos assim transferidos por uma ou mais instituições deverá ser homogêneo e não pode integrar créditos litigiosos ou incobráveis. São, depois, emitidos títulos correspondentes a unidades de participação (são equiparadas às cotas de fundos de investimento brasileiros), representativos dos valores do fundo cuja aquisição confere titularidade, na parte proporcional, aos respectivos tomadores ".
\end{abstract}

$\mathrm{Na}$ Espanha, essa operação é conhecida como titulizacion, tendo sido praticada ao longo dos anos 80, do século XX. A Comissão Nacional do Mercado de Valores era o órgão responsável pela fiscalização dessas operações. Uma característica da titulizacion na Espanha, é que essa operação é utilizada pelas instituições financeiras que realizam financiamento imobiliário e tais créditos hipotecários serão utilizados como lastro das cédulas hipotecárias emitidas aos investidores.

Conforme Garcia e Molina (2001, p.1), desde os anos 1970, inicia-se um processo de transformação da atividade financeira por meio do desenvolvimento de novas tecnologias de produtos financeiros, negociados nos mercados organizados e voltados principalmente para os investidores institucionais (fundos de pensão e seguradoras), e gestores de patrimônio.

Securitizar tem o significado de converter determinados créditos em lastro para títulos ou valores mobiliários a serem emitidos posteriormente. A securitização serve, portanto, como suporte para a emissão de títulos ou valores mobiliários.

De acordo com publicação no Financial Times (1997, p. 247), a securitização de ativos obteve rápido crescimento nos EUA. Surgiu na década de 1970, ao passo que na maioria dos outros países seu uso foi restringido. Porém, no Reino Unido, a relativa liberdade do sistema financeiro promoveu seu crescimento. 
Uma maneira de exemplificar-se essa operação exige que uma empresa de qualquer setor econômico possua em suas contas a receber um fluxo de recebíveis, ou seja, aluguel de imóveis ou equipamentos, vendas a prazo, bem como, qualquer forma de recebimentos referentes à sua atividade operacional e que possa legalmente ser transferido a um terceiro.

Esse fluxo de contas a receber pode ser segregado, por meio da realização de um contrato de cessão de direitos creditórios, estabelecido entre a empresa e uma sociedade de propósito específico.

A partir dessa operação de cessão de crédito, a sociedade de propósito específico será a única e legitima credora do fluxo de recebíveis, de forma que esse fluxo deverá ser segregado pela utilização de uma conta corrente da sociedade de propósito específico.

O objetivo principal nas estruturas de securitização é procurar mitigar ou segregar os impactos que a eventual falência, moratória voluntária ou outro evento de reorganização societária da empresa (cedente dos créditos) possa ter nos créditos cedidos. Os recebíveis devem ser transferidos em caráter definitivo para a sociedade de propósito (cessionário dos créditos).

O próximo passo contemplará a emissão de um título de crédito, geralmente uma debênture, por parte da sociedade de propósito específico a favor dos investidores, que estarão aplicando recursos por meio da compra dessas debêntures.

As debêntures emitidas possuem como garantia o fluxo de recebíveis, constituindose para os investidores numa aplicação de recursos financeiros com risco de crédito atrelado ao pagamento ou liquidação do fluxo de recebíveis, ou seja, os investidores estarão assumindo o risco de crédito dos devedores do fluxo de recebíveis. Caso ocorra algum percentual de inadimplência dos recebíveis, a sociedade de propósito específico possuirá um fluxo adicional de recebíveis, que ficará como garantia complementar e como forma de proteger os investidores na hipótese de default.

Esse termo default é bastante usado na língua portuguesa e significa inadimplência, entende-se, aqui, um conjunto de acontecimentos que afetam o cumprimento das obrigações de uma empresa. 
Pode-se afirmar que a securitização é uma estrutura de suporte para a emissão de títulos ou valores mobiliários, conhecida nos EUA como Asset Backed Securities$A B S$, ou securitização lastreada por ativos, provocando dissociar seu rating de crédito do rating da empresa originadora.

Uma abordagem de Saunders (2000, p. 587) destaca a securitização de ativos como a combinação em pacotes e a venda de empréstimos e outros ativos sob a forma de títulos. Pela securitização têm permitido que as carteiras de ativos de instituições financeiras tornem-se cada vez mais liquidas.

Nesse sentido, de acordo com o Bank for International Settlements - BIS, já existe uma estrutura de securitização nos EUA que permite à instituição financeira possuidora de recebíveis proteger-se do risco de crédito desses recebiveis sem, necessariamente, precisar desfazer-se desses recebíveis, por meio da cessão de crédito.

Essa estrutura é conhecida nos EUA como securitização sintética (conforme a figura a seguir), pois os ativos continuam com a instituição financeira, porém, ela compra uma proteção de crédito junto a uma sociedade de propósito específico - SPE que emitirá títulos conhecidos como Credit Linked Notes, e têm como lastro a garantia dos recebíveis da instituição financeira. Com os recursos captados pela sociedade de propósito especifico - SPE, serão adquiridos títulos do Tesouro Americano, por exemplo, US-Treasury Bill, US-Treasury Notes ou Treasury Bonds, conforme demonstrado no fluxo a seguir, permitindo que a instituição financeira consiga a proteção contra o risco de crédito ou risco de default da sua carteira de empréstimos: 
Figura 1 - Fluxo de Securitização Sintética

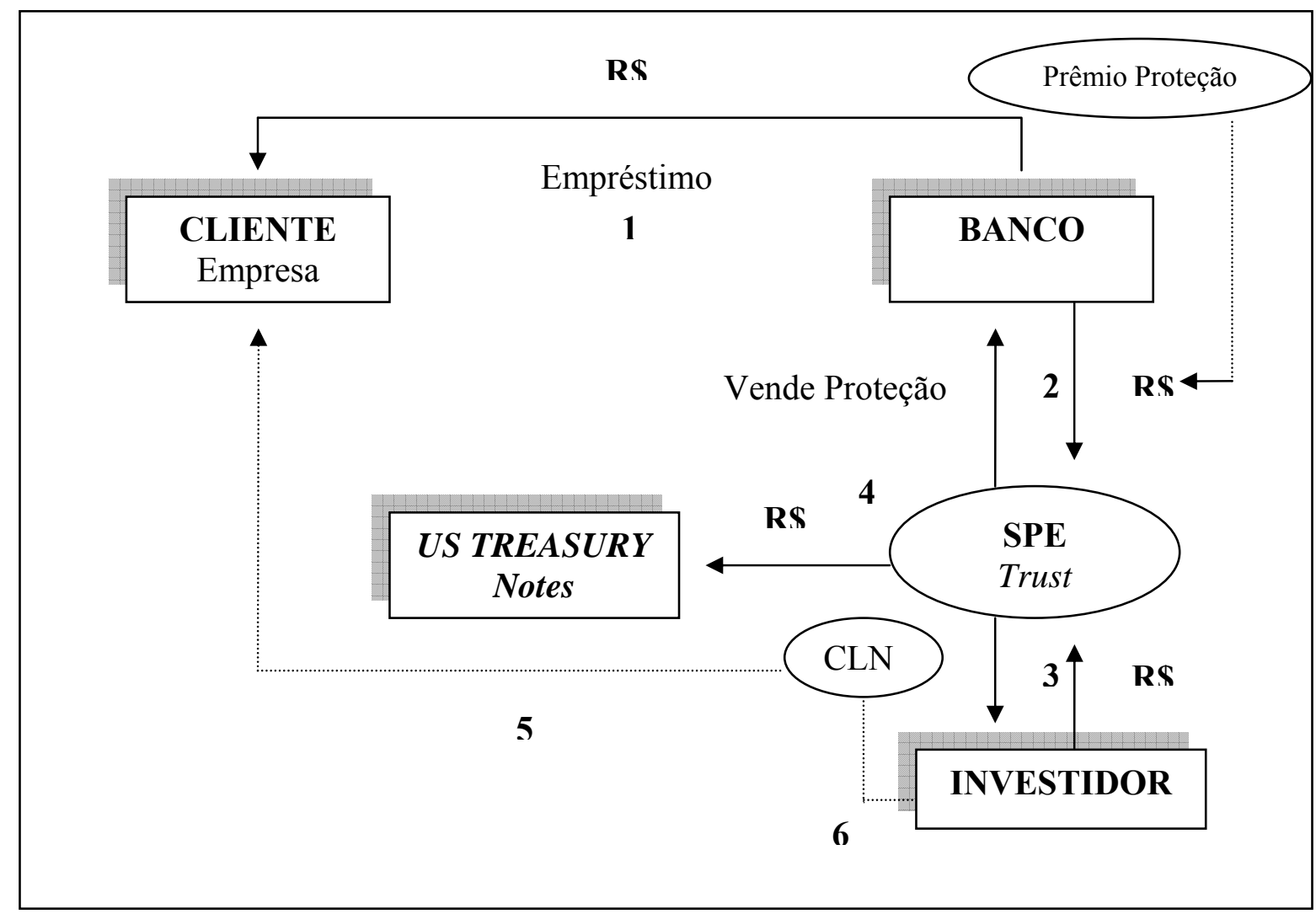

Fonte: Adaptado do BIS - Bank for International Settlements (2001)

em que:

instituição bancária realiza empréstimo;

instituição bancária compra proteção de crédito junto a SPE, pagando um prêmio;

SPE capta recursos junto a investidores, através da emissão de Credit Linked Note CLN;

SPE com os recursos da emissão da CLN compra US Treasury Notes;

CLN ficará ligada ao evento de default (inadimplência) do ativo de crédito e investidor assume o risco de crédito da CLN que está ligada ao evento de default.

A securitização bem-sucedida geralmente exige, pelo menos, uma classificação de risco de crédito "AA". Com o objetivo de exemplificação, um fabricante industrial com uma classificação de rating de crédito média de "B" possui dificuldades de financiar 
seu capital de giro junto aos bancos. Porém, esse fabricante vendeu bens de capital a clientes com uma classificação de rating de crédito forte "AA", gerando contas a receber em seu fluxo de caixa. Esse fluxo é geralmente denominado de recebíveis, podendo ser utilizado para estruturar uma operação de securitização, em que o fluxo de recebíveis será a garantia do pagamento do título emitido aos investidores, ou seja, não depende mais do risco do fabricante, mas, somente da capacidade dos devedores (clientes fortes) em saldar esse fluxo de recebíveis.

A securitização de ativos é uma operação financeira estruturada que possibilita a emissão de títulos mobiliários lastreados com ativos ou vinculados a um direito creditório ou simplesmente recebível, especialmente segregados, visando a eliminar ou minimizar o risco de crédito da companhia emissora dos títulos mobiliários.

Atualmente, diversos dispositivos legais disciplinam a securitização de ativos, securitização de créditos ou securitização de recebíveis, na maioria das vezes, decorrentes de empréstimos, financiamentos (inclusive imobiliários) e operações de arrendamento mercantil (leasing), realizadas no âmbito do mercado financeiro.

De acordo com Assaf (2001, p. 116), é notório o crescimento das operações de captações financeiras por meio de títulos emitidos pelos próprios tomadores de recursos.

Conforme Borges (1999, p. 126), dentre os vários motivos ou mesmo benefícios que as empresas devem obter, quando decidem pela realização de uma securitização de ativos podem-se destacar:

Necessidade de caixa (financiamento do capital de giro);

Obtenção de financiamento com altos volumes de recursos e prazos mais dilatados;

Custo de oportunidade mais atrativo do que as formas tradicionais de empréstimos bancários;

Diversificação dos financiadores, ou seja, ampliação da base de investidores (fundos de pensão e seguradoras) e

Melhoria da apresentação de suas demonstrações financeiras e índices financeiros. 
Dermine e Bissada (2005, p. 64), a securitização é o processo que permite a um determinado banco vender empréstimos a investidores, existem basicamente três motivos econômicos para que as instituições bancárias possam realizar a venda de empréstimos:

evitar o requerimento de capital, de acordo com a regulamentação definida do Comitê de Supervisão Bancária de Basiléia, sediado no BIS-Bank for International Settlements. O Banco Central do Brasil exige que os bancos tenham um nível mínimo de patrimônio (regulamentação de natureza prudencial), para absorver eventuais prejuízos no caso de inadimplência dos tomadores de crédito. A referida regulamentação sobre o patrimônio mínimo exigido para a cobertura de riscos de crédito é geralmente conhecida como Índice de Basiléia;

diversificação do risco de crédito e

obtenção de maior liquidez.

No caso das instituições financeiras bancárias, a securitização de ativos auxilia na economia de capital, uma vez que há redução dos ativos de empréstimos, e conseqüentemente, no processo de melhoria da liquidez e da diversificação do risco de crédito dos ativos que compõem a carteira de empréstimos. 


\section{Figura 2 - Estrutura Básica da Securitização de Ativos}

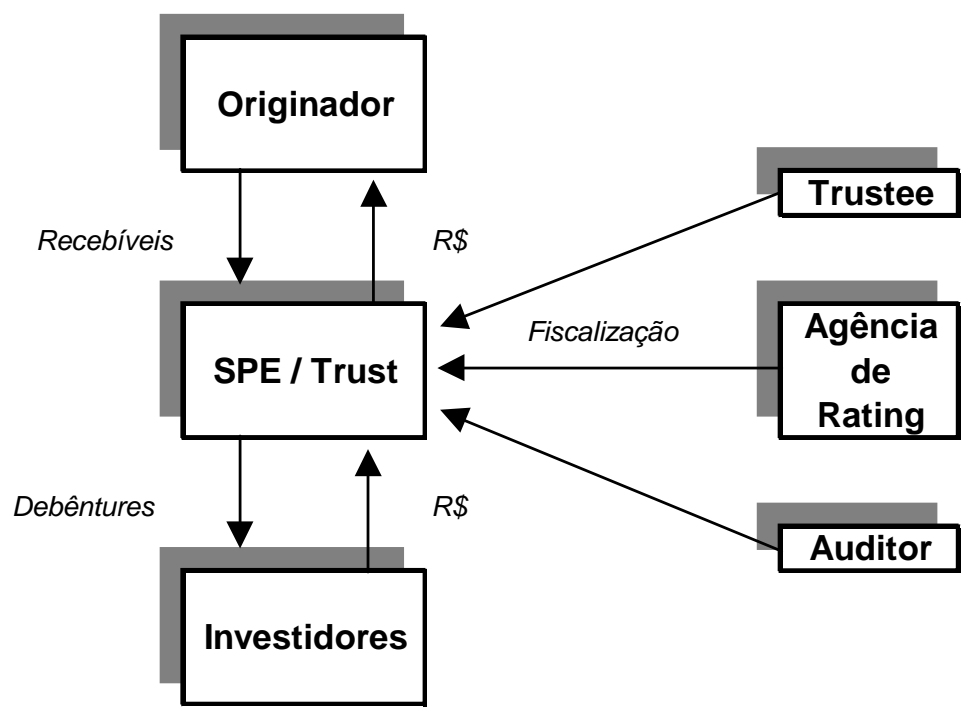

Fonte: Elaborada pelo Autor

A fundamentação da operação é que os valores mobiliários emitidos pela companhia securitizadora (trust) terão maior aceitação no mercado de capitais por não envolverem os riscos da empresa originadora, mas, somente os riscos dos recebíveis adquiridos pela securitizadora (trust), conforme demonstrado na figura acima.

A classificação de risco da operação se dará sobre o risco da securitizadora à medida que ela restringirá seu risco ao dos recebíveis que possui e ainda poderá contar com um garantidor. Desse modo, a securitizadora (trust) conseguirá obter melhor rating do que a originadora, conseguindo captar recursos a um custo inferior e oferecendo menor risco de crédito para os investidores.

De acordo com Gaggini (2003, p. 33), para melhor visualizar a diferença de riscos de crédito, sejam consideradas duas hipóteses em uma comparação ilustrativa:

Hipótese 1:

A companhia originadora opta pela captação de recursos por meio de uma emissão pública de debêntures quirografárias (sem garantia real). 


\section{Hipótese 2:}

A companhia originadora opta por uma operação de securitização de ativos, na qual o emissor das debêntures será uma sociedade de propósito específico - SPE, comumente denominada securitizadora.

Na primeira hipótese, a companhia originadora pretende captar recursos por meio da emissão própria de debêntures. Nesse caso, o risco das debêntures estará vinculado ao risco da sociedade emissora, ou seja, da companhia originadora. $\mathrm{Na}$ avaliação e análise de risco de crédito, serão consideradas todas as relações das quais a sociedade (companhia originadora) participa em função de seu negócio principal, influenciando diretamente a classificação de rating de crédito.

No caso de falência da companhia emissora das debêntures, os investidores concorrerão com os demais credores da empresa, habilitando seus créditos conforme a sua qualidade e aceitando a ordem de preferência de créditos de acordo com a lei de falência.

Assim, ocorrendo a falência da sociedade emissora das debêntures, os debenturistas terão de se submeter ao regime paritário, que será instaurado, sendo os bens da sociedade arrecadados para posterior venda em leilão judicial.

Com os recursos arrecadados por meio do leilão dos bens da companhia falida, serão pagos, primeiramente, os créditos de natureza trabalhista. Em seguida, serão pagos os créditos de natureza fiscal.

Restando ainda recursos, serão pagos os créditos quirografários. Exemplificando, seriam as debêntures emitidas sem garantias, bem como da maioria dos créditos habilitados na falência (concorrendo o debenturista com titulares de outros créditos simples, decorrentes de contratos em geral, duplicatas, notas promissórias, entre outros).

E, por último, na hipótese de ainda existirem recursos, serão pagos os créditos subordinados ou subquirografários como, por exemplo, a classe de debêntures subordinadas, que só prefere (antecede) aos acionistas da própria companhia falida. 
O risco de crédito de um investidor de debêntures estará centrado na qualidade do risco de crédito do emissor e, na hipótese de ocorrência da falência da companhia emissora das debêntures, existirá grande probabilidade de o debenturista não obter, sequer, a restituição do montante principal investido, devido ao grande número de credores que uma empresa possui, em decorrência da sua atividade de negócios diários.

Na segunda hipótese, a companhia originadora deverá optar por uma operação de securitização de ativos. Nesse caso, será constituída uma sociedade de propósito específico (sociedade securitizadora), que, será a emissora das debêntures. A companhia originadora utilizará a estrutura da securitização para segregar o risco dos recebíveis do seu próprio risco de crédito, com o objetivo de obter um custo menor de captação, pois, tal estrutura oferece um risco mitigado aos investidores.

Apesar de as debêntures emitidas pela sociedade de propósito especifico - SPE estarem submetidas ao mesmo regime jurídico das demais debêntures emitidas por qualquer empresa S/A, inclusive obedecendo à mesma ordem de preferência citada anteriormente, nesse caso, o risco de crédito será muito menor, restringindo-se ao eventual risco de inadimplência dos recebíveis.

Essa segregação do risco de crédito decorre do fato de que a sociedade de propósito específico - SPE é uma sociedade que tem como único objetivo adquirir os recebíveis, para posterior emissão das debêntures (ou outros valores mobiliários), não possuindo outros credores ou dívidas senão àquelas decorrentes da securitização, visto que essa sociedade não desempenha nenhuma outra atividade, diferentemente dos objetivos da companhia originadora.

Diante disso, somente existirão os investidores (debenturistas) como credores das debêntures da sociedade de propósito específico, sendo que terão seus créditos garantidos pelos recebíveis que a sociedade de propósito específico-SPE adquiriu da companhia originadora.

Na securitização, os recebíveis são baixados dos ativos da companhia originadora e com ela não guardam mais relação, de modo que, se esta vier a falir, tais recebíveis não serão arrecadados pela massa falida, visto que não mais pertencem à companhia originadora, mas, à sociedade de propósito específico-SPE, que os 
adquiriu (recebíveis), mediante o pagamento à vista do instrumento de cessão de crédito.

\section{4 - Principais Características dos Participantes da Estrutura de Securitização} Companhia Originadora:

É a empresa geradora de recebíveis ou qualquer pessoa jurídica que tenha fluxo de contas a receber, originados em vendas a prazo, por exemplo.

Esse fluxo de recebíveis será utilizado como lastro dos títulos a serem emitidos pela sociedade de propósito específico - SPE.

Exemplificando, pode-se destacar as lojas de departamentos, administradoras de cartão de crédito, empresas distribuidoras de água luz e gás, entre outras.

Os recebíveis são o fruto das vendas a prazo já realizadas, faturadas e ainda não vencidas, representando uma obrigação irretratável do sacado.

Sociedade de Propósito Específico - SPE

A Sociedade de Propósito Específico - SPE, também conhecida na literatura internacional como Special Purpose Company - SPC ou Special Purpose Vehicle SPV, é uma sociedade de grande importância e relevância na estrutura de securitização, pois é por meio dessa sociedade que se viabiliza a segregação dos riscos dos recebíveis dos riscos da companhia originadora.

A sociedade de propósito específico - SPE, também conhecida por Trust (de acordo com as leis inglesas a Trust é uma sociedade de propósito específico), refere-se a empresa especialmente constituída para comprar o fluxo de recebíveis e, utilizandose desse lastro (recebíveis), para a emissão títulos e valores mobiliários.

A sociedade de propósito específico - SPE tem duas funções no âmbito de uma securitização de recebíveis: comprar os recebíveis da companhia originadora e simultaneamente, fazer a emissão das debêntures para os investidores. Essa operação se assemelha ao trust, assim entendido por Salomão Neto (1996, p. 20): 
"Implica o trust a transferência de propriedade ou titularidade sobre um bem corpóreo, móvel ou imóvel, ou incorpóreo, como os direitos, a um terceiro denominado trustee, a quem incumbe exercer os direitos adquiridos em benefício de pessoas designadas expressamente no instrumento criador do trust, ou indicadas pela lei ou jurisprudência na falta de tal instrumento, chamadas de beneficiários. Alternativamente, podem se constituir trust em benefício de pessoas determinadas, mas, com vistas à perseguição de determinados objetivos".

Conforme Meirelles, toda a legislação brasileira que regulamentou a criação de Sociedades de Propósitos Específicos - SPE está sob a forma de Companhias Securitizadoras de Créditos Imobiliários - CSCls e Companhias Securitizadoras de Créditos Financeiros - CSCFs.

As CSCls são instituições não financeiras constituídas sob a forma de sociedades anônimas, tendo por finalidade a aquisição e securitização de créditos imobiliários, bem como a emissão e colocação, junto aos investidores, de Certificados de Recebíveis Imobiliários - CRIs. As CSCFs são passíveis de securitização de todos os créditos financeiros, inclusive os oriundos de operações de empréstimos, de financiamento e de arrendamento mercantil.

A respeito das vantagens proporcionadas pelas sociedades de propósito específico SPE, escreve Salomão Neto (1996, p. 26):

\begin{abstract}
"a sociedade de propósito específico que capta os recursos dos investidores, por meio da emissão de debêntures, não está contaminada por outras dívidas da sociedade alienante dos créditos (companhia originadora), nem pelos riscos de sua atividade empresarial, o que diminui os riscos para os investidores e, portanto, permite juros mais baratos".
\end{abstract}

A sociedade de propósito específico deve possuir a forma de sociedade anônima S/A, tipo societário, que permite a captação de recursos do público investidor mediante a negociação de suas debêntures no mercado de capitais.

Conforme Requião (1998, p. 87):

"a sociedade anônima, com efeito, tornou-se eficaz instrumento do capitalismo precisamente porque permite à poupança particular participar dos empreendimentos, sem que o investidor, modesto ou poderoso, se vincule à responsabilidade, além da soma investida, e pela possibilidade de, a qualquer momento, sem dar conta de seu ato a ninguém, negociar livremente os títulos, obtendo novamente a liquidez monetária desejada. Graças à tão simples mecanismo, a poupança privada pôde ingressar comodamente no mundo dos negócios, tornando-se a sociedade anônima o instrumento popular do capitalismo, fundamental para o seu predomínio, sem o qual não se poderia conceber sua expansão". 
De acordo com Gaggini (2003, p. 50), "a sociedade anônima, nos termos da Lei 6.404/76, modificada pela Lei $n^{0} 10.303 / 01$, é a sociedade que tem seu capital social dividido em ações, uma espécie de valor mobiliário, que igualmente aos demais valores mobiliários, pode ser ofertada publicamente como forma de obtenção de capitais".

São características das sociedades anônimas - S/A, a divisão do capital social em ações, a limitação da responsabilidade do acionista ao valor das ações subscritas ou adquiridas e a livre negociação de suas ações nas bolsas de valores e mercado de balcão, bem como dos demais valores mobiliários, visto tratar-se de sociedade de capital, em que a transferência de ações não afeta a estrutura da sociedade. $\mathrm{O}$ mercado de balcão compreende as operações do mercado de capitais celebradas fora das bolsas de valores, mas, com participação dos agentes do sistema de distribuição de valores mobiliários, ou seja, as corretoras de títulos e valores mobiliários - CTVM e as distribuidoras de títulos e valores mobiliários - DTVM.

A sociedade de propósito específico - SPE deve assumir a forma de companhia aberta, com o devido registro junto à CVM - Comissão de Valores Mobiliários, para que possa emitir títulos e valores mobiliários.

Trustee ou Agente Fiduciário:

O agente fiduciário é o representante legal da comunhão de interesses dos debenturistas, protegendo seus direitos junto à emissora. Sua presença é obrigatória nas emissões públicas de debêntures.

$\mathrm{Na}$ estrutura de securitização de ativos, o trustee é representado pelo agente fiduciário, que tem a função e obrigação de supervisionar a perfeita liquidação dos títulos da carteira.

O agente fiduciário será o responsável pela administração de todo o processo da securitização, representando legalmente os interesses dos investidores.

Sua função principal será emitir relatórios periódicos aos debenturistas (investidores das debêntures) sobre o desempenho da carteira, os índices de cobertura das garantias das debêntures e os resultados das auditorias internas. 
Outros Deveres e Atribuições do Agente Fiduciário:

fiscalizar a constituição das garantias;

intimar a companhia originadora a reforçar garantias, caso necessário;

declarar vencida a emissão de debêntures e executar suas garantias;

convocar assembléia (AGO e AGE) de debenturistas;

comparecer às assembléias de debenturistas para prestar-lhes informação e

renunciar à função de agente fiduciário na hipótese de situação de conflito de interesse em relação à empresa originadora dos recebíveis.

Agência de Classificação de Rating:

O rating é uma metodologia de classificação de risco de crédito, por meio da qual uma empresa independente se especializa na análise de governos, empresas, operações estruturadas, do tipo project finance e fundos de investimentos, entre outras entidades que ofereçam títulos publicamente, de modo a oferecer informações quanto à segurança e garantia dos emissores e títulos analisados.

De acordo com Securato (2002, p.183), uma empresa independente especializada em rating é denominada de agência de rating, que é uma organização que fornece serviços de análise, operando sob os princípios de independência, objetividade, credibilidade e disclousure. A observância desses princípios é essencial já que, em última instância, o reconhecimento de uma agência classificadora depende exclusivamente da disposição do investidor em acreditar e aceitar seu julgamento.

A indústria de classificação de bônus originou-se nos EUA, em 1900, por John Moody, o primeiro a publicar uma classificação de rating de crédito, quando fundou a Moody's Investors Service, e analisou o risco de crédito de mais de 250 ferrovias americanas da época. A Standard \& Poor's, por sua vez, foi fundada em 1860, com a finalidade de publicar informações financeiras e prestar serviços de pesquisa. 
Uma classificação de rating de crédito é uma avaliação do risco de inadimplência de um determinado bônus ou título, feita por uma agência privada independente. As classificações não refletem outros riscos, tais como o risco de taxa de juros, nem são recomendações para comprar ou vender bônus em particular.

Em 1993, a SR Rating iniciou suas operações, no Brasil, tornando-se a primeira agência de classificação de riscos do país. A decisão de introduzir tais serviços no mercado brasileiro coincidiu com o fim de um longo período inflacionário, viabilizando-se o principal ingrediente para a análise de riscos, que é a previsibilidade.

A estabilidade monetária trazida pelo Plano Real viabilizou os serviços de classificação de risco no Brasil. A primeira operação da SR Rating foi realizada em 1994, por meio da classificação de risco das debêntures da Mesbla Trust, uma sociedade de propósito específico - SPE. Essa operação se tornou um case study na história do rating brasileiro. A Mesbla Trust foi a primeira operação pública de securitização realizada no Brasil.

$\mathrm{Na}$ expansão de classificação de risco de crédito no Brasil, as três agências internacionais, Moody's Investors Service, Standard \& Poor's e Fitch Investors Service estabeleceram-se aqui. 
A agência de rating contratada deverá dar suporte na estruturação da securitização, sendo responsável pela divulgação do rating (classificação do risco de crédito) da empresa originadora dos recebíveis, durante toda a vida útil da securitização.

Dada à complexidade dessa estrutura, a presença de uma agência de rating indicará aos debenturistas uma avaliação especializada e independente sobre a segurança da estrutura da securitização, sua qualidade das garantias, o comportamento do fluxo dos recebíveis e os poderes do agente fiduciário (trustee) no zelo dos interesses dos debenturistas.

Devido à sofisticação do mercado de valores mobiliários nacional, o rating passou a ser exigência. Um exemplo disso é que, no FIDC, o rating é obrigatório, ou seja, a regulamentação da CVM para o FIDC obriga a contratação de uma empresa de rating, com o objetivo de que o FIDC seja avaliado e trimestralmente reavaliado.

A agência de rating estabelecerá uma classificação ou nota de crédito (conforme demonstrado nos quadros a seguir), geralmente, baseada nos principais aspectos destacados abaixo:

processos de concessão de crédito que a empresa originadora possui;

seus controles internos (compliance);

sua capacidade ou nível de seus sistemas de informática;

análise do nível de inadimplência histórica e atual do fluxo de recebíveis;

qualidade e eficácia do sistema de cobrança dos recebíveis;

nível de over-collateral (sobre-colaterização ou garantia adicional no fluxo de recebíveis), que a sociedade de propósito específico possui e

forma da segregação dos contratos originais do fluxo de recebíveis. 
Quadro 4 - Classificação de Títulos da Moody's e Standard \& Poor's

\begin{tabular}{|l|l|l|l|l|}
\hline & Alta Qualidade & $\begin{array}{l}\text { Grau } \\
\text { Investimento }\end{array}$ & Subpadrão & Especulativo \\
\hline \multirow{2}{*}{ Moody's } & Aaa & A & Ba & Caa \\
& Aa & Baa & B & C \\
\hline \multirow{2}{*}{ S \& P } & AAA & A & BB & CCC \\
& AA & BBB & B & D \\
\hline
\end{tabular}

Fonte: Brigham e Weston (2000, p. 800)

\section{Quadro 5 - Características da Classificação dos Títulos}

\begin{tabular}{|c|c|c|}
\hline Moody's & S \& Poor's & Características da Classificação dos Títulos \\
\hline Aaa & AAA & $\begin{array}{l}\text { Rating mais alto possível. A capacidade de pagamento de } \\
\text { juros e principal é muito forte. }\end{array}$ \\
\hline $\mathrm{Aa}$ & AA & $\begin{array}{l}\text { Rating com capacidade muito forte de pagamento. Esse } \\
\text { grupo compreende a classe de obrigações de elevada } \\
\text { qualidade. }\end{array}$ \\
\hline A & A & $\begin{array}{l}\text { Dívidas com esse rating possuem capacidade forte de } \\
\text { pagamento de juros e principal. Entretanto, são pouco mais } \\
\text { sucetíveis às mudanças adversas de circunstâncias e } \\
\text { condições econômicas. }\end{array}$ \\
\hline Baa & BBB & $\begin{array}{l}\text { Dívidas classificadas nessa categoria são consideradas } \\
\text { possuidoras de capacidade adequada de pagamento de } \\
\text { juros e restituição de principal. Porém, as condições } \\
\text { econômicas desfavoráveis ou mudanças de circunstâncias } \\
\text { podem levar a uma redução maior dessa capacidade de } \\
\text { pagamento em relação às categorias superiores. Essas } \\
\text { dívidas são obrigações de qualidade média. }\end{array}$ \\
\hline $\begin{array}{l}\text { Ba } \\
\text { B } \\
\text { Caa }\end{array}$ & $\begin{array}{l}\text { BB } \\
B \\
\text { CCC }\end{array}$ & $\begin{array}{l}\text { Dívidas classificadas nessa categoria são consideradas, em } \\
\text { geral, predominantemente especulativas. }\end{array}$ \\
\hline C & $\mathrm{C}$ & $\begin{array}{l}\text { Esse nível de rating é reservado para obrigações de renda } \\
\text { variável cujos juros não estão sendo pagos. }\end{array}$ \\
\hline D & D & $\begin{array}{l}\text { Dívidas nessa categoria encontram-se em situação de } \\
\text { inadimplência, e o pagamento de juros e/ou de restituição } \\
\text { do principal encontra-se em atraso. }\end{array}$ \\
\hline
\end{tabular}

Fonte: Adaptado de Ross et al. (2002, p. 466) 
Auditor Independente:

Os auditores independentes são empresas ou pessoas físicas especializadas no exame dos registros contábeis e demonstrações financeiras das companhias, procurando diagnosticar a consistência das informações prestadas pelas companhias. Trata-se de uma exigência legal para a obtenção e manutenção da condição de companhia aberta, devendo o auditor independente estar registrado na CVM - Comissão de Valores Mobiliários;

O Auditor será uma empresa de auditoria independente que terá a atribuição de comprovar todos os relatórios operacionais emitidos tanto pela empresa originadora quanto pelo agente fiduciário, bem como pelos relatórios emitidos pela instituição financeira responsável pela cobrança do fluxo de recebíveis e

Deverá, também, auditar os processos de concessão de crédito da empresa originadora durante a vida útil da operação, bem como auditar os valores de transferência dos recebíveis para a sociedade de propósito específico - SPE.

Investidor:

Os investidores são os compradores das debêntures de emissão da sociedade de propósito específico - SPE.

Geralmente os investidores são classificados como:

Fundos de Pensão (Públicos e Privados);

Fundos de Investimento (Asset Management);

Seguradoras;

Instituições Financeiras (Bancos e Private Bank) e

Empresas Superavitárias (caixa disponível para aplicações). 


\title{
2.5 - Cessão de Crédito
}

A aquisição dos recebíveis pela Sociedade de Propósito Específico será por meio da realização do instrumento de cessão de crédito.

A cessão de crédito, também conhecida por cessão de direitos creditórios, é um instrumento que pode ser utilizado pelas instituições financeiras (bancos múltiplos, bancos comerciais, bancos de investimento e sociedades de crédito financiamento e investimento), para a captação ou aplicação de recursos.

Stuber et al. (1999, p. 26) descreve que:

\begin{abstract}
"a securitização de recebíveis ocorre mediante a cessão, por parte de uma instituição financeira cedente, de determinados créditos (recebíveis) que aquela detém para com terceiros (devedores), oriundas de empréstimos, financiamentos e operações de arrendamento mercantil".
\end{abstract}

De acordo com Securato (2002, p. 328), "ressalta-se que a cessão de crédito é um instrumento contratual bancário criado pela Lei número 3.071 de 1916, tendo sido muito utilizado entre as décadas de 1960 e 1990, cujo objetivo principal é dar liquidez (gerar funding) às instituições de pequeno porte".

A cessão de crédito é regulada pelo Código Civil, nos artigos 1.065 e subseqüentes. Esse primeiro artigo dispõe que o credor pode ceder o seu crédito, se isso não se opuser à natureza da obrigação, à Lei ou à convenção com o devedor. Portanto, não será qualquer credor que será elegível para a realização da cessão.

Conforme Gaggini (2003, p. 44), a cessão de crédito, em sua modalidade convencional, ou seja, aquela que decorre do acordo de vontades entre cedente e cessionário, pode se efetuar a título gratuito ou oneroso. A onerosidade da cessão é fato determinante da operação, visto que mediante o pagamento da cessão dos créditos, recebido da sociedade de propósito específico pela companhia originadora, é que essa última consegue alcançar o seu objetivo final de toda a operação, ou seja, a captação de recursos obtidos com a conversão dos créditos em títulos e valores mobiliários (debêntures). 
Entre a sociedade de propósito específico - SPE e a companhia originadora, a cessão dos recebíveis é contratada de maneira irretratável e irrevogável, de modo que a SPE torna-se, em definitivo, a legítima titular dos créditos adquiridos.

De acordo com Toneto (1996, p. 56), a cessão de crédito tem sido também usada com a finalidade de aumentar o respaldo patrimonial de tomadores de crédito. Para tanto, separam-se ativos creditícios de uma sociedade que pretenda captar recursos, sendo tais ativos cedidos à sociedade específica criada com o propósito único de adquiri-los. Essa sociedade de propósito específico terá, então, os créditos como seu único ativo, sem obter a princípio, qualquer passivo que não o valor devido à cedente dos créditos. Em uma segunda etapa, a sociedade de propósito específico captará recursos e usará tais recursos para pagar pela cessão de crédito efetuada.

A cessão de crédito ficará subordinada a uma série de requisitos e formalidades, de acordo com o que consta no Cógido Civil Brasileiro:

"Na cessão, salvo disposição em contrário, estão abrangidos todos os seus acessórios (art. 1.066) e o devedor pode opor, tanto ao cessionário como ao cedente, as exceções que lhe competirem no momento em que tiver conhecimento da cessão, embora não possa opor ao cessionário de boa fé a simulação do cedente (art. 1.072)"; e

"A cessão do crédito deve ser necessariamente comunicada ao devedor (art. 1.069), e não vale em relação a terceiros se não for celebrada por instrumento público ou particular revestido das solenidades do art. 135 (art. 1.067)".

O Novo Código Civil, Lei $n^{\circ} 10.406$, de 10.01.2004, traz a seguinte redação para este dispositivo legal:

"Artigo 290 - A cessão do crédito não tem eficácia em relação ao devedor, senão quando a este notificada; mas por notificado se tem o devedor que, em escrito público ou particular, se declarou ciente da cessão feita".

Em uma primeira análise, tal dispositivo de notificação do devedor pode parecer um obstáculo à cessão de crédito realizada entre a sociedade de propósito específico SPE e a companhia originadora, à medida que os ativos de créditos (recebíveis), objetos da cessão, são decorrentes de grande número de contratos originados, de 
modo que a notificação de cada um dos devedores (sacados) desses contratos, torna-se operacionalmente difícil e mesmo com custos financeiros elevados.

Para solucionar tal questão, pode-se adotar o procedimento de incluir, no próprio contrato que será posteriormente objeto de cessão para a sociedade de propósito específico - SPE, cláusula notificando o devedor (sacado) de que o crédito poderá ser objeto de securitização de ativos ou ser cedido a terceiros. Dessa forma, o devedor é notificado antecipadamente, tomando ciência de tal situação e expressando sua concordância eliminando, portanto, a problemática da notificação do devedor prevista no Código Civil Brasileiro.

Nesse sentido, conforme Noronha (2004, p. 89), é destacado que:

\begin{abstract}
"diante de tal dipostivo legal, as indústrias e o comércio que objetivam realizar um contrato de securitização (cessão de lastro), já no ato da entrega da mercadoria ou no ato da compra da mercadoria, fazem com que o devedor aceite a cessão a qual vem declinada no boleto ou no carnê ou até em documento anexo ao recibo de entrega da mercadoria pela expressão inserida: "Este crédito será cedido para (designação do veículo securitizador)" ou, se ainda não houver sido constituído o veículo, a expressão será a seguinte: "Declaro estar ciente e em concordância de que o presente crédito é passível de cessão".
\end{abstract}

Com tal procedimento elimina-se a emissão de notificações para os devedores (sacado) da originadora dos ativos e, também, eventuais dúvidas e questionamentos dos clientes.

\title{
2.5.1 - Tipos de Cessão de Crédito
}

De acordo com o Código Civil Brasileiro, existem dois tipos de cessão de crédito, ou seja, a cessão de crédito com coobrigação do cedente e a cessão de crédito sem coobrigação do cedente.

Cessão de Crédito com cláusula "com a coobrigação do cedente":

Caracteriza-se pelo fato de o cedente responsabilizar-se perante o cessionário (comprador), pelo pontual pagamento dos créditos cedidos, independentemente de os devedores originais terem liquidado ou não as suas obrigações. 
Em uma cessão de crédito com cláusula de coobrigação do cedente, o cessionário possui o direito de regresso do crédito ao cedente, caso o devedor dos créditos torne-se inadimplente.

É comum realizar-se cessão com coobrigação do cedente (vendedor), quando tratar-se de créditos originados com pessoas físicas (crédito direto ao consumidor), pois se torna tarefa difícil a avaliação individual de cada crédito que venha a compor a carteira.

A taxa de juros negociada entre o cedente (vendedor) e o cessionário (comprador) na cessão com coobrigação do cedente geralmente é menor do que na cessão sem coobrigação do cedente, pois, o cessionário terá o direito de regresso dos créditos vencidos e não pagos, transferindo seu risco de crédito para o cedente. Portanto, a inadimplência (créditos não liquidados pelos sacados) recairá sobre o cedente (vendedor).

Cessão de crédito com cláusula "sem a coobrigação do cedente":

Também conhecida como venda definitiva ou sem direito de regresso, ou seja, o cedente (vendedor dos recebíveis) não terá nenhuma responsabilidade perante o cessionário (comprador dos recebíveis), no caso de os créditos tornarem-se inadimplentes.

Utiliza-se a cessão de crédito sem coobrigação, quando se tratar de créditos originados com empresas (pessoas jurídicas), em função de o cessionário poder avaliar o tipo de risco de crédito que estará assumindo, caso venha a comprar tais créditos em que os sacados serão empresas.

Nessa modalidade (cessão de crédito sem coobrigação), a taxa de juros negociada entre o cedente (vendedor) e o cessionário (comprador) deverá considerar o risco de inadimplência dos devedores (sacados), devido ao cessionário assumir sozinho o risco de crédito e nesse caso, exigirá uma taxa de juros maior.

Em ambas as modalidades de cessão de crédito, os créditos negociados serão diminuídos dos ativos do cedente, conforme classificação contábil específica. No caso da cessão de crédito com coobrigação, os créditos cedidos e não liquidados retornarão ao balanço do cedente (vendedor), em virtude da cláusula contratual de 
direito de regresso que o cessionário poderá exercer, em caso de inadimplência dos créditos.

\subsection{2 - Tipos de Coobrigação}

Por definição, a coobrigação é uma obrigação conjunta, podendo ser solidária ou subsidiária, e o Código Civil brasileiro, nos artigos 896 e 915, específica cada um desses dois tipos de coobrigação.

Coobrigação Solidária:

É considerada coobrigação solidária quando o cessionário (comprador) pode executar o devedor principal (crédito original adquirido) como o próprio coobrigado (cedente), indistintamente.

Juridicamente, pode-se equiparar a coobrigação solidária ao aval, ou seja, nesse caso, o credor (cessionário), tanto pode cobrar o devedor (sacado) como o avalista do crédito indistintamente, com o objetivo de receber os recursos a que tem direito.

Coobrigação Subsidiária:

É considerada coobrigação subsidiária quando o cessionário (comprador) executar primeiramente o devedor (sacado) e, após tal cobrança, não obtiver sucesso. Poderá, assim, cobrar o cedente que está coobrigado.

Juridicamente, pode-se também equiparar a coobrigação subsidiária ao instrumento de fiança, ou seja, nesse caso, o credor somente poderá acionar o fiador do crédito em segundo lugar, isto é, após primeiramente efetuar a cobrança do devedor original do crédito (sacado).

A cessão de crédito é o instrumento utilizado na transferência dos recebíveis da empresa ou instituição financeira, originadoras para as instituições financeiras compradoras desses recebíveis. As figuras (3 e 4) a seguir, demonstram as estruturas de cessão de crédito entre instituições financeiras bancárias, bem como a estrutura de cessão de crédito entre empresas e instituições financeiras. 
Figura 3 - Estrutura da Cessão de Crédito entre Instituições Bancárias

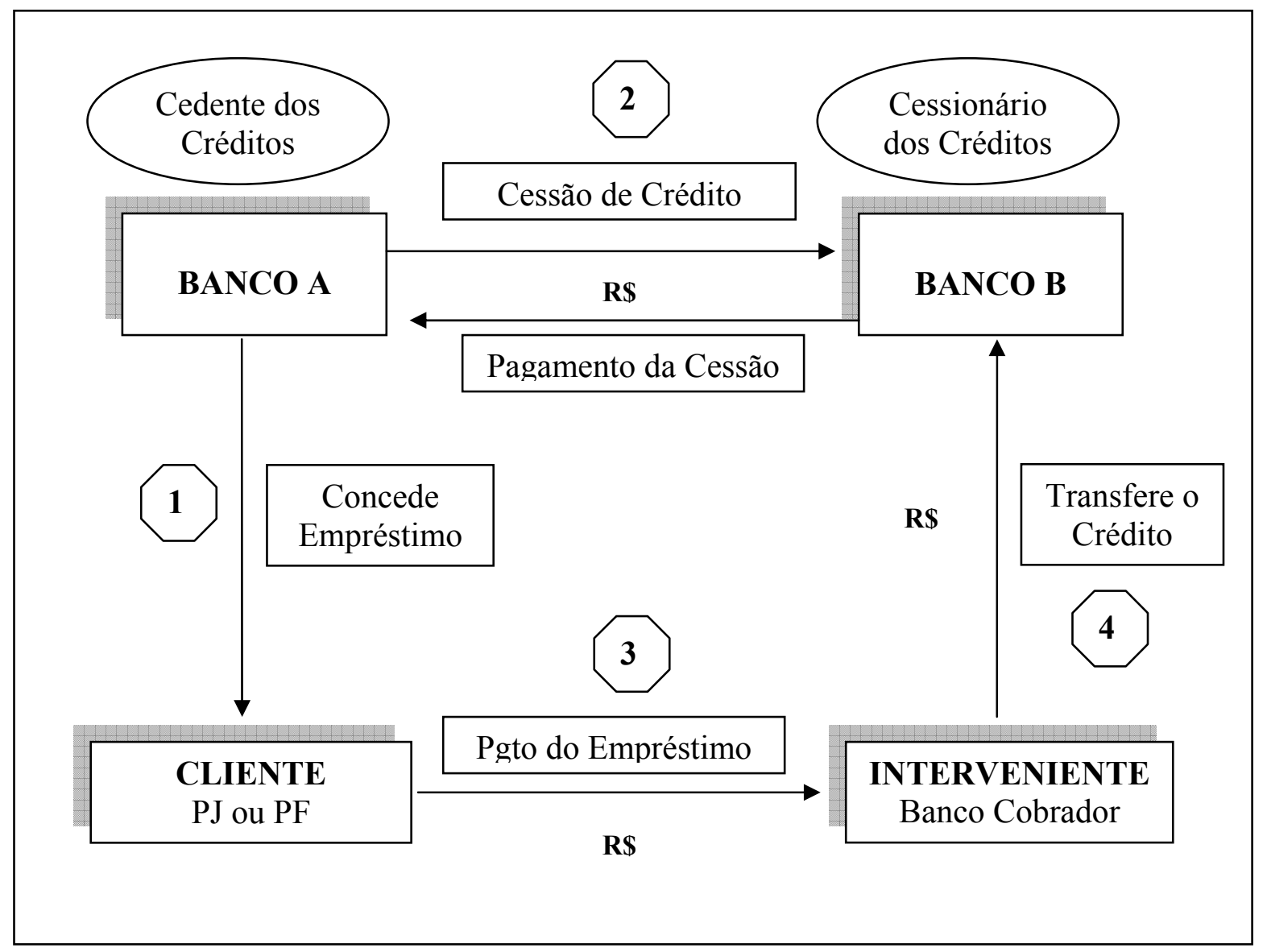

Fonte: Elaborada pelo Autor

em que:

O "Banco A" é o cedente (vendedor dos recebíveis), possui uma carteira de ativos de crédito e efetuará a sua venda por meio do instrumento de cessão de crédito ao "Banco B". O cedente ("Banco A") é uma instituição financeira que possui direitos creditórios originados por meio de empréstimos bancários a empresas (pessoa jurídica), ou créditos originados por meio de financiamentos de crédito direto ao consumidor - CDC e, realizando a cessão de crédito, e estará captando recursos por meio da venda desses créditos.

O "Banco B", que é o cessionário (comprador dos recebíveis), efetuará o pagamento em reais, correspondente ao valor presente dos créditos da cessão ao "Banco A". O cessionário é uma instituição financeira que será o comprador dos créditos, ou seja, estará aplicando recursos por meio da aquisição de direitos creditórios. 
O interveniente, geralmente é uma instituição financeira bancária, será o responsável pela cobrança dos recebíveis, ou seja, receber dos sacados e creditar o cessionário assumindo essa responsabilidade no contrato de cessão de crédito. Em alguns contratos de cessão, o interveniente poderá ser também uma empresa especializada em guarda de documentos e será responsável pela custódia dos documentos originais de cada crédito elegível do contrato de cessão.

No caso de uma cessão de crédito ser realizada com uma empresa (sociedade por quotas ou sociedade por ações), a empresa será a cedente dos créditos originados por ela junto aos seus clientes, ou seja, a cessão de crédito do seu respectivo contas a receber, será realizada, conforme demonstrado no fluxo a seguir:

\section{Figura 4 - Estrutura da Cessão de Crédito entre Bancos e Empresas}

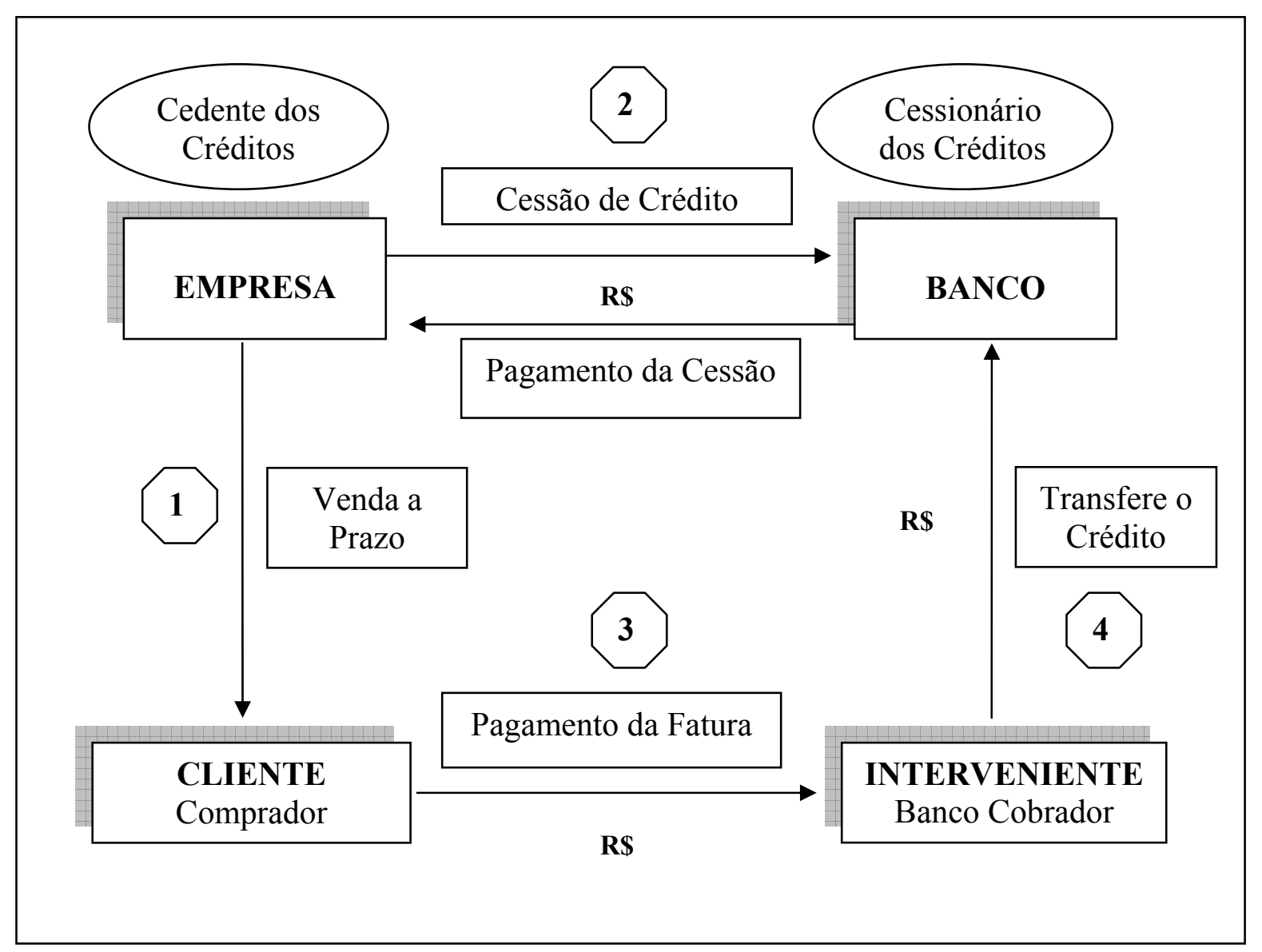

Fonte: Elaborada pelo Autor

As Resoluções do Conselho Monetário Nacional - CMN, nº 2686 e n 2836, autorizaram a cessão de crédito de operações praticadas pelas instituições financeiras e pelas sociedades de arrendamento mercantil às sociedades anônimas 
(S/A) que se caracterizem, exclusivamente, como companhias securitizadoras de créditos, e às sociedades de propósito específico.

De acordo com o quadro a seguir, destaca-se as principais normas regulamentares refrentes à cessão de direitos cerditórios:

Quadro 6 - Normas regulamentares referentes à Cessão de Crédito

\begin{tabular}{|c|c|c|}
\hline Resoluções & Finalidade & Data \\
\hline Resolução nº 1962 - Bacen & $\begin{array}{l}\text { Altera e consolida normas sobre } \\
\text { cessões de crédito }\end{array}$ & $27 / 08 / 1992$ \\
\hline Resolução n² 2561- Bacen & $\begin{array}{l}\text { Altera e consolida normas sobre } \\
\text { cessões de crédito }\end{array}$ & $05 / 11 / 1998$ \\
\hline Resolução nº 2686 - Bacen & $\begin{array}{l}\text { Estabelece condições para a } \\
\text { cessão de créditos a } \\
\text { sociedades anônimas de objeto } \\
\text { exclusivo e a companhias } \\
\text { securitizadoras de créditos } \\
\text { imobiliários }\end{array}$ & $26 / 01 / 2000$ \\
\hline Resolução nº 2836 - Bacen & $\begin{array}{l}\text { Altera e consolida normas sobre } \\
\text { cessões de crédito }\end{array}$ & $30 / 05 / 2001$ \\
\hline Resolução nº 2907 - Bacen & $\begin{array}{l}\text { Autoriza a constituição e } \\
\text { operação de Fundos de } \\
\text { Investimentos em Direitos } \\
\text { Creditórios - FIDCs }\end{array}$ & $29 / 11 / 2001$ \\
\hline Instrução Normativa nº 356 - CVM & Regulamenta os FIDCs & $24 / 01 / 2002$ \\
\hline
\end{tabular}

Fonte: Banco Central do Brasil

\section{6 - Os Modelos de Estruturas de Securitização de Ativos no Brasil}

No Brasil, o marco das operações off-balance (securitização de ativos) foi a constituição das sociedades de propósito específico, comumente chamadas de SPE. A primeira operação de securitização foi realizada em 1994, por meio da emissão de debêntures da Mesbla Trust que era uma sociedade de propósito específico, da operação de securitização da Mesbla Loja de Departamentos. 
De acordo com Chinen (2002, p. 32), "nos países de Direito Romano, como é o caso do Brasil, não existe a figura do trust", que é adotado nos EUA e demais países de direito Anglo-Saxão. Porém, para que as operações de securitização possam ser viabilizadas, foi necessária a criação de instituições semelhantes como, por exemplo, a Mappin Trust, Bahia Trust, entre outras, sendo chamadas de sociedade de propósito específico - SPE ou special purpose company - SPC.

A estrutura de securitização de ativos foi testada em seu limite, em função do caso da Mesbla Trust, pois, a Mesbla Loja de Departamentos (originadora dos recebíveis) entrou em concordata preventiva e, apesar disso, não provocou nenhum tipo de prejuízo financeiro aos investidores dos títulos emitidos pela Mesbla Trust, demonstrando que, esse tipo de estrutura é eficaz na segregação e mitigação dos riscos entre a empresa originadora e a sociedade de propósito específico - SPE.

De acordo com Meirelles e Bentivegna (2003, p. 53), existem alguns aspectos jurídicos relevantes que são imprescindíveis em todas as operações de securitização, para que haja uma efetiva segregação entre o risco inerente aos ativos e o risco atinente à empresa originadora. Para tanto, é recomendável que:

- a transferência dos direitos creditórios da originadora para a SPE seja absoluta, sem que a empresa originadora retenha titularidade legal sobre tais créditos transferidos à SPE;

- a SPE, assim como seus objetivos e relacionamento societário com a empresa originadora, deve ser estruturada de forma a evitar que ela seja tratada como parte dos ativos da empresa originadora, no caso de falência desta. Esse ponto é de crucial importância para as operações locais de securitização, ou seja, a efetiva segregação do risco de crédito entre a empresa originadora e a sociedade de propósito específico;

- além da total segregação societária entre a SPE e a empresa originadora, é preciso tomar as seguintes precauções (entre outras) relativamente à SPE, visando-a garantir que a SPE tenha poucas chances de se tornar insolvente ou de ser alvo de eventuais reclamações por parte de credores (em geral, tais precauções aplicam-se também aos Fundos de Recebíveis). 
- Nesse contexto, a SPE:

- deve ter objeto social específico e restrito;

- não deve participar de qualquer fusão, incorporação ou evento semelhante durante o prazo em que suas obrigações estejam em aberto;

- não deve contrair dívidas adicionais àquelas que sejam imprescindíveis à finalidade para a qual tenha sido criada e

- deve obrigar-se, entre outros, a: manter seus próprios livros e registros contábeis, separados de qualquer outra entidade; manter demonstrações financeiras independentes; pagar suas despesas com recursos próprios; observar todas as formalidades societárias; não garantir ou assumir divida de nenhuma outra entidade; não dar seus ativos em garantia, exceto no âmbito da operação de securitização estruturada e, de maneira geral, manter-se como uma empresa independente.

Em virtude de uma série de fatores de natureza macroeconômica e principalmente por questões relacionadas aos custos envolvidos nesse tipo de estruturação (securitização por meio da SPE) não houve uma ampliação expressiva do volume de emissões de títulos securitizados, ou seja, não existiu uma demanda por esse tipo de captação estruturada como ocorreu nos países desenvolvidos, principalmente nos EUA.

Conforme a Fitch Ratings (2002, p. 2), em muitos mercados, as securitizações normalmente utilizam um trust ou uma SPE. No Brasil, já citada, a utilização de SPEs iniciou-se nos anos 90, do século XX, por meio da Resolução n 2.493 do Banco Central, permitindo a securitização de operações financeiras. Porém, a criação de uma SPE é custosa do ponto de vista tributário. Não existem isenções tributárias, há sim considerável carga tributaria incidente sobre as SPE. Prova disso é que em uma securitização tradicional envolvendo a venda de ativos, a SPE estará sujeita a impostos sobre o valor da operação como, por exemplo, o PIS e Cofins, além da aplicação de Imposto de Renda sobre o lucro marginal, da contribuição social sobre o lucro líquido e da CPMF. 
Com o objetivo de tornar a estrutura de securitização de ativos no Brasil uma fonte alternativa de captação de recursos, porém, de maneira mais eficiente do ponto de vista de custos tributários, ao final de 2001, com base na Resolução $n^{\circ} 2907$, do Conselho Monetário Nacional, a Comissão de Valores Mobiliários - CVM publicou a Instrução Normativa $n^{\circ} 356$ regulando a constituição dos fundos de recebíveis que, posteriormente, foi aperfeiçoada pela instrução da própria Comissão de Valores Mobiliários - CVM n 393, de julho de 2003.

Os aspectos estruturais desses fundos de investimentos em direitos creditórios, bem como suas vantagens fiscais e operacionais, são descritos na seção a seguir.

\section{7 - Fundos de Investimentos em Direitos Creditórios - FIDC}

Tais fundos são considerados condomínios, não possuindo personalidade jurídica, não podem falir, não podem emitir instrumentos de divida e todo seu patrimônio pertence a seus cotistas e os recursos de seu patrimônio podem ser alocados na aquisição de direitos creditórios, que foram originados de operações dos segmentos financeiro, industrial, comercial, imobiliário, arrendamento mercantil, prestação de serviços e hipotecas.

Também foram normatizados pela Instrução Normativa $n^{\circ} 356$ da Comissão de Valores Mobiliários - CVM, de 17 de dezembro de 2001, os fundos de recebíveis denominados FICFIDC - Fundos de Investimento em Cotas de Fundos de Investimento em Direitos Creditórios, apelidados pelo mercado de FAC de recebíveis. Esses fundos devem alocar $95 \%$ de seu patrimônio em cotas de fundos de recebíveis.

O fundo de recebível pode ser administrado por banco múltiplo, comercial, de investimento, Caixa Econômica Federal, sociedades de crédito, financiamento e investimento, distribuidoras e corretoras de títulos e valores mobiliários.

Os Fundos de Recebíveis na forma de condomínios são uma comunhão de recursos que destina parcela preponderante (é aquela que excede $50 \%$ do PL do fundo) do respectivo patrimônio líquido para a aplicação em direitos creditórios. 
Os direitos creditórios são originários de operações realizadas nos segmentos financeiro, industrial, comercial, imobiliário, de arrendamento mercantil, de prestação de serviços, bem como de hipotecas.

Exemplos de recebíveis (direitos creditórios):

- Vendas de varejo - CDC (crédito direto ao consumidor);

- Crédito consignado;

- Financiamento de veículos;

- Financiamento imobiliário;

- Mensalidades escolares;

- Empréstimos a pessoas jurídicas;

- Recebíveis comerciais;

- Faturas de cartão de crédito;

- Contratos de locação de galpão indústrial e

- Contratos de compra e venda de energia.

Além dos direitos creditórios (no mínimo $50 \%$ da carteira), os fundos de recebíveis podem aplicar em títulos públicos, CDBs, RDBs e demais ativos de renda fixa, exceto cotas do Fundo de Desenvolvimento Social - FDS.

Os fundos de recebíveis possuem dois tipos de cotas, ou seja, as cotas Seniores, que têm preferência sobre as demais classes para efeitos de amortização e resgate, e as cotas Subordinadas, que podem ser várias, com direitos diversos, sempre subordinadas às cotas Seniores.

A distribuição das operações de securitização com a utilização dos FIDCs no ano de 2006 demonstra, conforme o gráfico abaixo, que existe uma concentração com recebíveis do setor de energia, bem como o setor financeiro, ou seja, recebíveis de 
bancos e financeiras, porém, outros setores da economia, principalmente indústria e imobiliário estão começando a destacar-se e com a perspectiva de crescimento econômico sustentado. Esse tipo de operação de captação de recursos deverá ser mais utilizada nesses segmentos da cadeia produtiva.

\section{Gráfico 4 - Distribuição Setorial de Operações de Securitização por Ativo- Lastro em 2006}

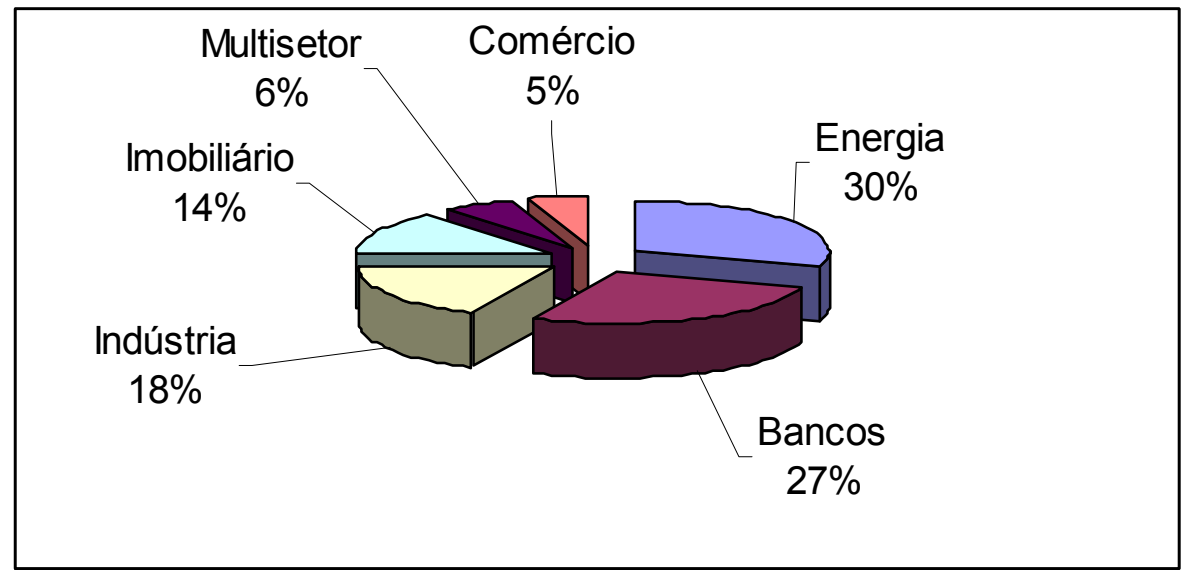

\section{Fonte: CVM (2006)}

Os fundos de recebíveis na forma de condomínios, de acordo com a instrução da Comissão de Valores Mobiliários - CVM poderão ser abertos ou fechados.

Fundos abertos:

Condomínio em que os investidores podem solicitar resgate de cotas, em conformidade com o disposto no regulamento do fundo, ou seja, são exemplo dos Fundos de Investimento Financeiro (FIF), aqueles em que os cotistas podem solicitar o resgate de suas cotas a qualquer momento.

Fundos Fechados:

Condomínio cujas cotas somente são resgatadas ao término do prazo de duração do fundo ou em virtude de sua liquidação, admitindo-se a amortização de cotas por disposição do regulamento ou por decisão da assembléia geral de cotistas. Esse tipo de fundo é ideal para operações em que a carteira de recebíveis não tenha liquidez satisfatória, e, portanto, permitirá o planejamento do fluxo de caixa. 
Os Fundos de Recebíveis (abertos e fechados) somente poderão receber aplicações, bem como ter cotas negociadas no mercado secundário, quando o subscritor ou o adquirente das cotas for investidor qualificado.

A administração do fundo deverá ser exercida por banco múltiplo, banco comercial, banco de investimento, Caixa Econômica Federal, sociedade de crédito, financiamento e investimento, por sociedade corretora de títulos e valores mobiliários ou por sociedade distribuidora de títulos e valores mobiliários.

A instituição financeira administradora terá poderes para praticar todos os atos necessários à administração do fundo e para exercer os direitos inerentes aos direitos creditórios que integrem a carteira do fundo.

Todos os fundos de recebíveis serão obrigatoriamente classificados por agência classificadora de risco em funcionamento no País, ou seja, as chamadas agências de rating. A nota conferida pela agência de rating deverá ser atualizada trimestralmente e, em caso de alteração, publicada como fato relevante, além disso, as taxas, as despesas e os prazos adotados pelo fundo devem ser idênticos para todos os condôminos.

Todo fundo de direitos creditórios deverá, obrigatoriamente, divulgar o regulamento do fundo prevendo, no mínimo, o seguinte:

- forma de constituição, se condomínio aberto ou fechado;

- taxa de administração e critério para sua fixação;

- taxa de desempenho ou de performance, quando for o caso, e critério detalhado sobre a sua cobrança;

- demais taxas e despesas;

- política de investimento, discriminando inclusive os critérios de elegibilidade dos direitos creditórios e

- condições para emissão, negociação, amortização e resgate de cotas. 


\section{Figura 5 - Estrutura dos Fundos de Direitos Creditórios - FIDC}

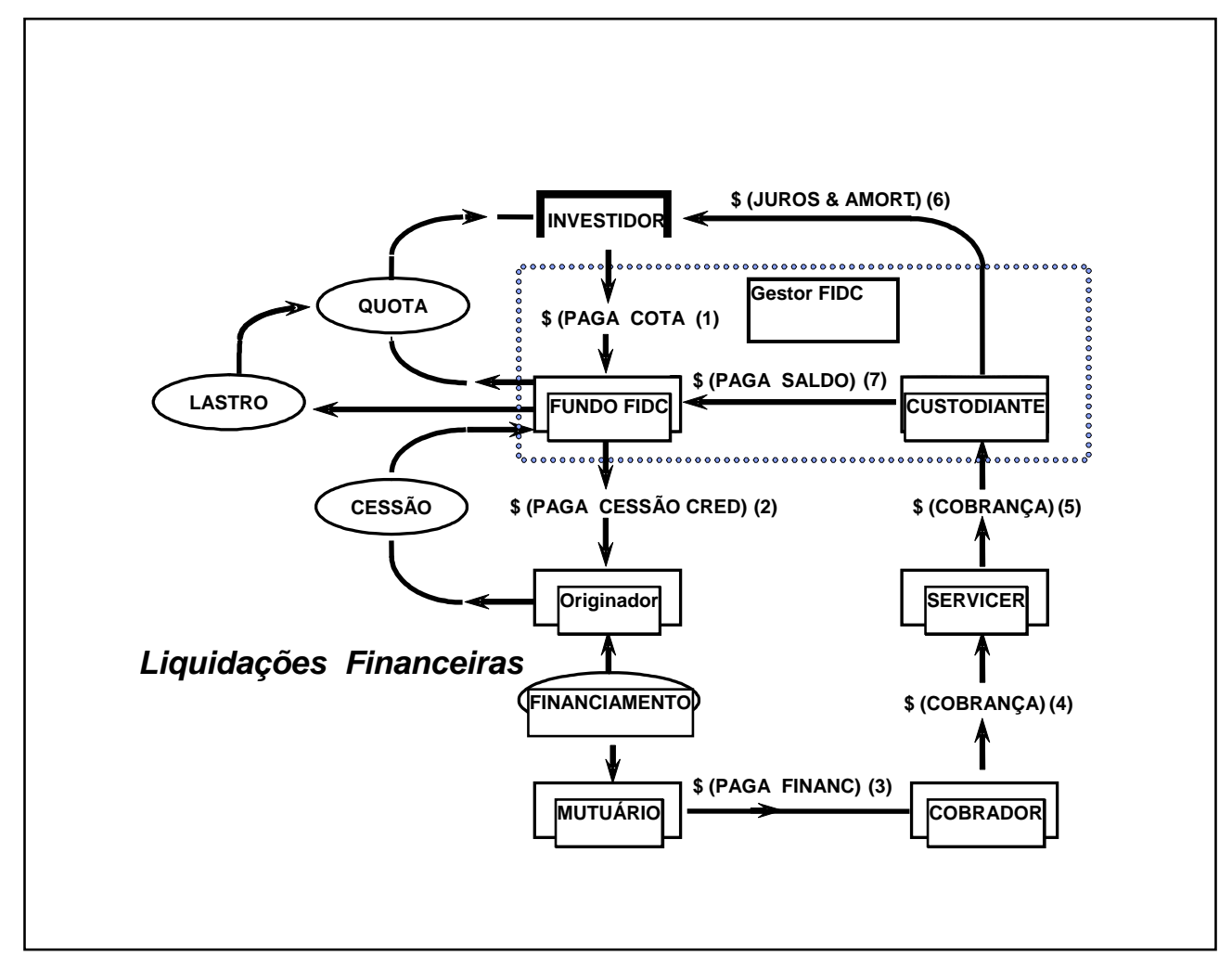

Fonte: Integral Trust (2006, p. 45)

Como demonstrado na figura (estrutura do FIDC), o Fundo de Recebíveis é um tipo de fundo que tem características especiais e cujos principais aspectos que devem merecer a atenção do estruturador e do originador são:

1. Documentação:

- Formalização dos créditos (rotinas e processos);

- Sistema de processamento de dados do originador (hardware e software) e

- Rotinas e procedimentos de aprovação de crédito.

2. Estatística de Cobrança:

- Transferência das informações (independência);

- Atrasos, default (não pagamentos) e

- Recuperação de crédito (cobrança extra-judicial). 
3. Operacionalização do Fundo de Recebível:

- Troca de informação com o banco responsável pela cobrança (meios de transmissão de arquivos eletrônicos);

- Custodiante e administrador;

- Política de liquidez e

- Estrutura de garantias (over-collateral).

A figura a seguir, indica a segregação de risco de crédito entre o originador dos recebíveis e o FIDC. O objetivo dessa segregação é de proteção ao investidor, em relação há eventual falência ou recuperação extra-judicial da empresa originadora dos recebíveis. Logo, essa estrutura permite que o FIDC possa obter uma classificação de rating de crédito satisfatória ou de baixo risco. 


\section{Figura 6 - Fluxo Operacional dos Fundos de Direitos Creditórios}

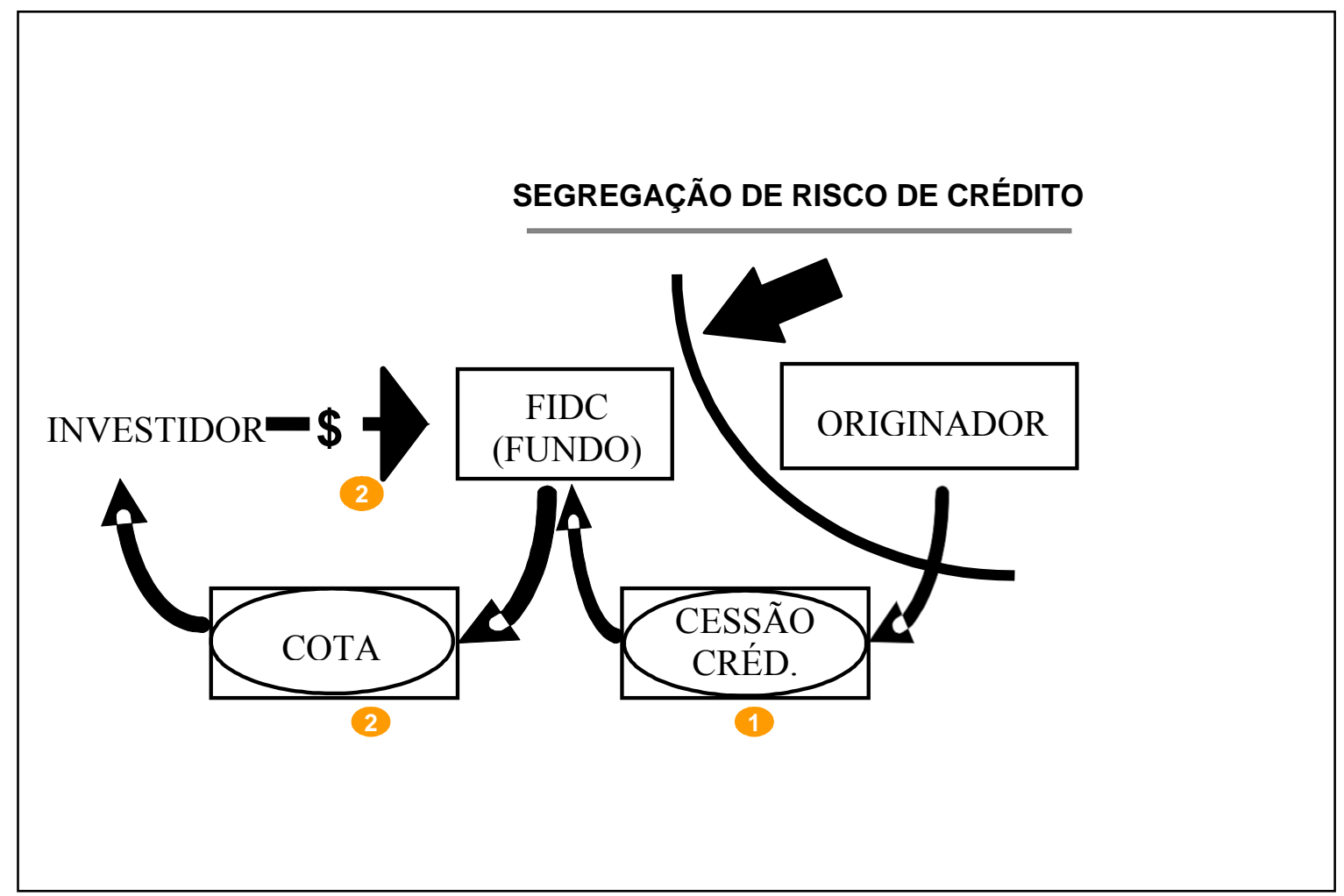

Fonte: Integral Trust (2006, p. 47)

Os fundos de recebíveis forneceram o arcabouço legal e operacional necessários para a segregação do risco do originador, garantindo ao investidor que, no vencimento dos recebíveis, estará assegurado o retorno do investimento do cotista investidor. Um exemplo da mitigação de risco por parte do investidor foi o caso Parmalat, que mesmo em caso extremo de crise na empresa cedente dos créditos (Parmalat), os cotistas dos Fundos de Recebíveis saíram protegidos pelo sistema de proteção e segregação de riscos que a estrutura de securitização oferecem.

Nesse caso, o Fundo Parmalat era composto por recebíveis performados, ou seja, de vendas já realizadas e obteve o rating "AAA" da agência Standard \& Poor's. Após a descoberta da fraude contábil da controladora italiana e iniciada a crise da Parmalat no Brasil, que chegou a suspender os pagamentos aos fornecedores e também o fornecimento de leite, a agência Standard \& Poor's reavaliou o rating de crédito do fundo e manteve a mesma nota estabelecida inicialmente, ou seja, a nota de rating "AAA". Não houve alteração em relação à segurança dos recebíveis que faziam parte da carteira do fundo. 
Por meio dos Fundos de Recebíveis, as empresas poderão utilizar, de acordo com suas estratégias de gestão financeira, as quatro principais premissas:

- fonte de recursos para suprir as necessidades de capital;

- alavancagem de novos recursos;

- nova alternativa para a mudança do perfil de endividamento e

- possibilidade de maior eficiência operacional.

Existem benefícios para o originador utilizar a estrutura de securitização, ou seja, os recursos captados podem custar menos do que um empréstimo direto no seu balanço, por meio de dívida bancária ou emissão de debêntures, por exemplo. Isso é possível graças à segregação do risco e do reforço de crédito (over-collateral) que a estrutura permite, fazendo com que o rating de crédito da securitização seja melhor do que o rating de crédito da empresa originadora dos recebíveis, além de viabilizar investimentos por parte de um grupo de investidores que é novo para muitas empresas: os investidores institucionais (fundos de pensão e seguradoras).

Conforme o quadro, a seguir, é demonstrado o expressivo crescimento das operações estruturadas de Fundos de Recebíveis - FIDC, realizadas no período entre 2000 a 2006.

Os dados reforçam o acentuado crescimento da securitização de recebíveis, por meio da operação de FIDC, em relação aos demais instrumentos de captação de recursos no mercado de capitais nos últimos 4 anos.

\section{Quadro 7 - Distribuição das Operações Registradas na CVM - em \%}

\begin{tabular}{|l|c|c|c|c|c|c|c|}
\hline \multicolumn{1}{|c|}{ Tipos de Underwriting } & $\mathbf{2 0 0 0}$ & $\mathbf{2 0 0 1}$ & $\mathbf{2 0 0 2}$ & $\mathbf{2 0 0 3}$ & $\mathbf{2 0 0 4}$ & $\mathbf{2 0 0 5}$ & $\mathbf{2 0 0 6}$ \\
\hline \hline Emissão Primária de Ações & $4,00 \%$ & $5,06 \%$ & $4,16 \%$ & $1,87 \%$ & $16,85 \%$ & $6,36 \%$ & $25,85 \%$ \\
BDRs / Bônus & $13,64 \%$ & $0,00 \%$ & $0,00 \%$ & $0,00 \%$ & $0,00 \%$ & $0,00 \%$ & $0,00 \%$ \\
Distribuição Secundária de Ações & $34,43 \%$ & $17,06 \%$ & $20,20 \%$ & $20,30 \%$ & $17,65 \%$ & $14,25 \%$ & $27,92 \%$ \\
Debêntures Simples & $20,76 \%$ & $54,44 \%$ & $57,70 \%$ & $42,45 \%$ & $33,86 \%$ & $60,53 \%$ & $22,77 \%$ \\
Debêntures Conversíveis a Ações & $4,07 \%$ & $2,19 \%$ & $0,26 \%$ & $0,56 \%$ & $2,39 \%$ & $0,00 \%$ & $0,00 \%$ \\
Notas Promissórias & $21,55 \%$ & $19,67 \%$ & $15,35 \%$ & $17,32 \%$ & $8,45 \%$ & $3,83 \%$ & $8,01 \%$ \\
CRI & $1,54 \%$ & $1,58 \%$ & $1,55 \%$ & $4,95 \%$ & $1,52 \%$ & $3,06 \%$ & $1,20 \%$ \\
FIDC - Fundo de Recebíveis & $0,00 \%$ & $0,00 \%$ & $0,79 \%$ & $12,54 \%$ & $19,29 \%$ & $11,97 \%$ & $14,25 \%$ \\
\hline \multicolumn{1}{|c|}{ Total } & $100,00 \%$ & $100,00 \%$ & $100,00 \%$ & $100,00 \%$ & $100,00 \%$ & $100,00 \%$ & $100,00 \%$ \\
\hline
\end{tabular}

Fonte: CVM / Anbid (2006) 
Quadro 8 - Empresas que lançaram FIDCs no mercado de capitais

\begin{tabular}{|c|c|c|c|}
\hline Empresas Originadoras & $\begin{array}{ll}\text { Data } & \text { de } \\
\text { lançamento } & \\
\end{array}$ & Setor & $\begin{array}{l}\text { Volume } \\
\mathrm{R} \$ \text { milhões }\end{array}$ \\
\hline Sadia S/A & Maio-2003 & Alimentos & 150.000 \\
\hline Telesp Celular S/A & Julho-2003 & Telefonia & 100.000 \\
\hline Pão de Acucar & Junho-2003 & Varejo & 400.000 \\
\hline Perdigão & Setembro-2003 & Alimentos & 80.000 \\
\hline Parmalat & Setembro-2003 & Alimentos & 150.000 \\
\hline Caterpillar & Novembro-2003 & Automotivo & 60.000 \\
\hline Concórdia / Grupo Sadia & Janeiro-2004 & Financeiro & 5.000 \\
\hline Copesul & Fevereiro-2004 & Petroquimica & 125.000 \\
\hline CPFL Piratininga & Fevereiro-2004 & Energia & 300.000 \\
\hline Sansuy & Outubro-2004 & Indústria & 20.250 \\
\hline Gradiente Eletrônica & Outubro-2004 & Eletrônica & 41.250 \\
\hline CESP & Dezembro-2004 & Energia & 450.000 \\
\hline Lojas Colombo & Dezembro-2004 & Moda & 160.000 \\
\hline FICAP - Cabos Elétricos & Abril-2005 & Indústria & 40.000 \\
\hline Furnas II & Maio-2005 & Elétrica & 900.000 \\
\hline Quality Energia & Junho-2005 & Energia & 1.000 .000 \\
\hline Cataguazes Leopoldina & Julho-2005 & Papel & 210.000 \\
\hline Telefônica & Julho-2005 & Telefonia & 120.000 \\
\hline GPAetatis/GP Investment & Agosto-2005 & Ivestimentos & 84.000 \\
\hline Zoomp & Setembro-2005 & Moda & 48.000 \\
\hline Gradiente Eletrônica & Setembro-2005 & Eletrônica & 37.500 \\
\hline CESP & Outubro-2005 & Energia & 650.000 \\
\hline Motorola Industrial & Outubro-2005 & Eletrônica & 538.000 \\
\hline Anhanguera/Grupo Siemens & Novembro-2005 & Eletrônica & 600.000 \\
\hline Caiuá - Grupo Rede & Janeiro-2006 & Elétrica & 110.100 \\
\hline Cemig & Janeiro-2006 & Energia & 900.000 \\
\hline CEEE & Fevereiro-2006 & Energia & 115.450 \\
\hline Sabesp & Março-2006 & Saneameno & 250.000 \\
\hline Grupo Brasil & Março-2006 & Indústria & 85.000 \\
\hline Fornecedores Petrobrás & Março-2006 & Petrôleo & 100.000 \\
\hline Tigre Industrial & Março-2006 & Indústria & 127.500 \\
\hline Marcopolo & Abril-2006 & Automotivo & 96.000 \\
\hline CESP & Agosto-2006 & Energia & 650.000 \\
\hline Dedini-Dulcini & Agosto-2006 & Mecânica & 76.000 \\
\hline Saneamento Sergipe & Setembro-2006 & Saneamento & 50.000 \\
\hline Cobra Comercial & Outubro-2006 & Informática & 250.200 \\
\hline Finexia Telecom & Novembro-2006 & Telefonia & 200.000 \\
\hline FIEP Industrial & Novembro-2006 & Indústria & 130.000 \\
\hline Petrobrás & Dezembro-2006 & Petrôleo & 100.000 \\
\hline
\end{tabular}

\section{Fonte: CVM (2007)}

Os dados desse quadro 8, indicam que, empresas de diversos setores econômicos estão utilizando os fundos de recebíveis como alternativa de captação de recursos no mercado de capitais brasileiro. 


\section{8 - Estudo Comparativo entre a Sociedade de Propósito Específico e os Fundos de Recebíveis - FIDC}

Nesse estudo comparativo foram levantados alguns pontos que favoreceram os fundos de recebíveis em detrimento das estruturas convencionais de securitização de ativos, conforme destacam-se no quadro a seguir:

\section{Quadro 9 - Comparação de Custos Iniciais e de Manutenção}

\begin{tabular}{|l|l|}
\hline Securitização Convencional & Fundos de Recebíveis \\
\hline Custos (\$) & Custos (\$) \\
\hline Constituição da SPC & Taxa do Administrador \\
\hline Contratação do Agente Fiduciário & Contratação do Agente Fiduciário \\
\hline Contratação de Auditoria & Contratação de Auditores \\
\hline Contratação de Agência de Rating & Contratação de Agencia de Rating \\
\hline Contratação de Banco Servicer & Não necessário \\
\hline Assessoria Jurídica & Assessoria Jurídica \\
\hline Registro das Debêntures (CVM) & Não necessário \\
\hline Publicações Legais & Publicações Legais \\
\hline Despesas de Marketing e Road Show & Marketing e Road Show \\
\hline Impressão de Prospectos & Impressão de Prospectos \\
\hline Parecer Legal (casos especiais) & Não necessário \\
\hline Registro das Debêntures (CETIP) & Não necessário \\
\hline Despesas Gerais & Despesas Gerais \\
\hline
\end{tabular}

Fonte: Elaborado pelo Autor

Em relação às Despesas Tributárias foram destacados os itens descritos, conforme o quadro a seguir:

\section{Quadro 10 - Despesas Tributárias}

\begin{tabular}{|l|l|}
\hline Securitização Convencional & Fundos de Recebíveis \\
\hline Despesas & Despesas \\
\hline Impacto na SPE: & Impacto no Fundo: \\
\hline PIS/COFINS = 3,65\% & PIS/COFINS = Isento \\
\hline $\begin{array}{l}\text { IRRF = **Tabela do IR de Renda Fixa } \\
\text { (incidência nas aplicações financeiras } \\
\text { das sobras de caixa) }\end{array}$ & IRRF = Isento \\
\hline IRPJ e CSSL =34\% & IRPJ e CSLL = Isento \\
\hline $\begin{array}{l}\text { CPMF = 0,38\% (sobre o giro da } \\
\text { carteira na SPC) }\end{array}$ & CPMF = Alíquota Zero \\
\hline Impacto para os Investidores: & Impacto para os Quotistas: \\
\hline $\begin{array}{l}\text { IRRF = de 22,5\% à 15\%, conforme a } \\
\text { Tabela do IR de Renda Fixa (sobre o } \\
\text { ganho nominal das Debêntures) }\end{array}$ & $\begin{array}{l}\text { IRRF = de 22,5\% à 15\%, conforme a } \\
\text { Tabela do IR de Renda Fixa (sobre o } \\
\text { rendimento nominal da cota sênior) }\end{array}$ \\
\hline
\end{tabular}

Fonte: Elaborado pelo Autor 
Pode-se concluir que os fundos de recebíveis possuem uma vantagem financeira em relação à Sociedade de Propósito Específico - SPE, ou seja, os fundos de recebíveis acabam sendo constituídos por meio de uma estrutura mais "leve", com custos administrativos e custos fiscais inferiores aos custos de uma securitização de ativos convencional.

Conseqüentemente, as operações de fundos de recebíveis vêm sendo cada vez mais utilizadas pelo mercado, apesar de ser um produto relativamente novo, demonstrando estar-se diante de uma nova estrutura operacional com grande potencial de utilização pelas empresas, ou seja, como uma nova forma de captação de recursos, bem como pelos investidores institucionais na aplicação de recursos nesses próximos anos.

Nesse sentido, o aparecimento dos fundos de recebíveis, no mercado de capitais brasileiro, registra o fim dos obstáculos para o pleno desenvolvimento do mercado de securitização, ampliando substancialmente o potencial de captação de recursos, tanto para as empresas de elevado risco de crédito como para as empresas de baixo risco de crédito, podendo inclusive, ser empresas de capital aberto ou capital fechado.

Devido à expansão das operações de securitização por meio dos FIDCs, a CVM Comissão de Valores Mobiliários publicou, em 08 de dezembro de 2006, a Instrução CVM N ${ }^{\circ} 444$, que dispõe sobre o funcionamento de Fundos de Investimento em Direitos Creditórios Não-Padronizados (FIDC-NP), ou seja, que permite a securitização de ativos exóticos e, com isso, o objetivo foi o de ampliar os tipos de recebíveis (lastro para a securitização).

A referida Instrução dispõe sobre a constituição e o funcionamento dos FIDCs. Considera-se Não-Padronizado o FIDC cuja política de investimento permita a realização de aplicações, em quaisquer percentuais de seu patrimônio líquido, em direitos creditórios do tipo: 
I. Que estejam vencidos e pendentes de pagamento quando de sua cessão de crédito para o fundo;

II. Decorrentes de receitas públicas originárias ou derivadas da União, dos Estados, do Distrito Federal e dos Municípios, bem como de suas autarquias e fundações;

III. Que resultem de ações judiciais em curso, constituam seu objeto de litígio, ou tenham sido judicialmente penhorados ou dados em garantia;

IV. Cuja constituição ou validade jurídica da cessão para o FIDC seja considerada um fator preponderante de risco;

V. Originados de empresas em processo de recuperação judicial ou extrajudicial;

VI. De existência futura e montante desconhecido, desde que emergentes de relações já constituídas e

VII. De natureza diversa, não enquadráveis no disposto no inciso $\mathrm{I}$, do art. $2^{\circ}$, da Instrução CVM n 356, de 17 de dezembro de 2001.

De acordo com essa Instrução da CVM, somente poderá receber aplicações, e obter cotas negociadas em mercado secundário, o adquirente das cotas que for investidor qualificado e o valor nominal unitário das cotas for de, no mínimo, de $\mathrm{R} \$$ 1.000.000,00 (um milhão de reais).

Nos Fundos de Investimentos em Direitos Ceditórios Não Padronizados (FIDCs-NP), será permitido incluir recebíveis de alto risco de crédito, como dívidas contra o setor público ou empresas em liquidação judicial, entre outros créditos duvidosos. Nesse sentido esse novo fundo de recebíveis permitirá que os investidores qualificados obtenham melhor rentabilidade para seus investimentos de longo prazo. 


\title{
CAPÍTULO 3 - METODOLOGIAS DE AVALIAÇÃO E RATING DE EMPRESAS BRASILEIRAS
}

\begin{abstract}
"Mecanismos de mejora del crédito, evaluados a través del rating dado por las agencias de clasificación. Esta evaluación tiene como finalidad ser um instrumento analítico del que se sirven los inversores de renta fija"...

Susana Blanco García (Universidad Complutense de Madrid)
\end{abstract}

Nesse capítulo será apresentada a revisão da literatura aplicada às metodologias de rating e avaliação de empresas, bem como uma síntese dos trabalhos científicos publicados recentemente. O termo rating significa índice, indicador, ou seja, um processo de classificação por meio de comparações. O rating pode ser do emitente, refletindo sua capacidade em honrar qualquer compromisso, de uma maneira geral, ou de uma emissão de um título específico, em que é considerada apenas a capacidade do emitente em honrar o título ou obrigação financeira.

Por rating de crédito entende-se, segundo Altman (2000, p. 75), a avaliação da capacidade creditícia de empresas corporativas. É função da empresa de rating informar aos investidores ou credores a probabilidade de não receberem todos os pagamentos do principal e juros, em relação a determinado título, por exemplo.

Portanto, a classificação do rating de crédito é uma medida utilizada mundialmente para a avaliação do risco de não-pagamento (inadimplência ou default) de uma empresa. As empresas especializadas na elaboração de rating de crédito corporativo possuem metodologias próprias, que serão abordadas mais adiante.

Segundo Sanvicente e Minardi (1999, p.1), "quando se concede um crédito, uma preocupação importante está associada com a possibilidade de que o cliente entre em recuperação extrajudicial, e não honre os compromissos assumidos".

Conforme Altman et al. (2000, p. 75), em mercados como os EUA, por exemplo, os mercados de capitais tomaram o lugar dos bancos como fonte de financiamento de capital, e as agências de rating assumiram grande importância na administração de risco de crédito. 
Logo, o rating de crédito é um mecanismo de classificação da qualidade de crédito de uma empresa, ou país. O rating de uma empresa (ou país) tem como objetivo classificar o risco da empresa (ou do país) não ser capaz de cumprir com suas obrigações financeiras.

As cinco maiores empresas, especializadas em classificação de rating de crédito, em termos de participação de mercado, e que atuam no Brasil são: (1) Standard \& Poor's; (2) Fitch Atlantic Rating; (3) Moody's Investors Service; (4) Austin Asis e (5) SR Rating, que são também conhecidas como agências de classificação de riscos ou agências de rating.

Nesse trabalho, procurou concentrar a análise das três maiores empresas estrangeiras de classificação de rating de crédito presentes no Brasil, ou seja, as metodologias das empresas (1) Standard \& Poor's, (2) Fitch e (3) Mody's.

Atualmente, a atividade de classificação de risco ao redor do mundo é concentrada nas três empresas citadas acima.

De acordo com Costa (2005, p. 51), essas agências de classificação de riscos desenvolvem seus trabalhos para empresas do setor financeiro e não-financeiro, entidades do setor público e, organizações interessadas em classificar suas operações estruturadas.

O mecanismo de rating de crédito é benéfico tanto para as empresas, pois a classificação de risco tem um impacto direto no custo do financiamento, quanto para investidores, pois a classificação do risco facilita a tomada de decisão de investimento. Outro ponto importante é que as agências de classificação de risco são entidades independentes e o mecanismo de rating de crédito auxilia na melhora da transparência das operações no mercado de capitais.

O rating de crédito não trata diretamente de outro risco que o de crédito. Em particular, não trata, por exemplo, de risco de perdas por mudança em taxas de juros e outras variáveis de mercado. 


\section{1 - Rating de Empresas}

Ao redor do mundo, a atividade de rating vem sendo desenvolvida por agências como Standard \& Poor's Corporation, Moody's Investors Service e Fitch IBCA, dentre outras, que estão estabelecidas no Brasil, desde a década passada e classificam a qualidade dos ativos (títulos) oferecidos aos investidores, sendo um instrumento auxiliar na tomada de decisão para a concessão de crédito.

Conforme Costa (2005, p. 38), o rating corporativo pode representar o risco de crédito de uma organização como um todo e não especificamente de uma única operação.

Altman et al. (2000, p.1) destaca que "o risco de crédito é a mais antiga forma de risco nos mercados financeiros", ou seja, pode-se definir crédito como a "expectativa de uma quantia em dinheiro, dentro de um espaço de tempo limitado". Logo, o risco de crédito é a probabilidade de que essa expectativa não se cumpra. Ainda segundo o mesmo autor, os Bardi de Peruzzi, e os Acciaiulli dominaram o cenário bancário entre 1300 e 1345 DC, porém, os dois faliram em virtude de créditos inadequadamente concedidos e, provavelmente, foram as primeiras vítimas do risco de default.

Considerando que a palavra risco pode representar a probabilidade de ocorrer um evento de perda e que o rating é o seu processo de análise, então, o resultado final do processo de avaliação da qualidade do risco de crédito de uma empresa indicará a probabilidade de a empresa não cumprir suas obrigações junto aos credores. Portanto, segundo Costa (2005: p. 38), "o rating corporativo pode ser considerado como parâmetro importante no relacionamento contratual entre dois agentes econômicos".

Conforme Damodaran (2004, p.156), "o risco em um investimento pode ser mensurado pela variância nos retornos reais em relação ao retorno esperado", conforme demonstrado na figura a seguir: 
Figura 7 - Definição gráfica de risco

\section{Investimento livre de risco}

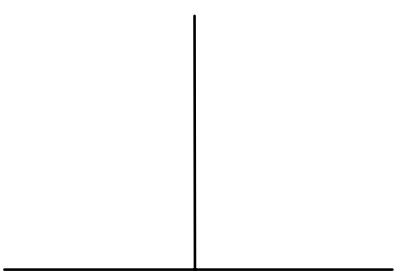

$\mathbf{R}(\mathbf{E})$
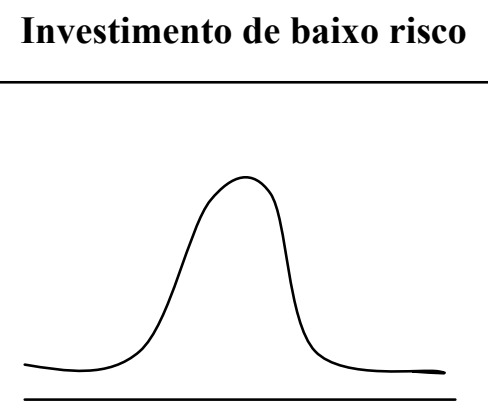

$\mathbf{R}(\mathbf{E})$
Investimento de alto risco

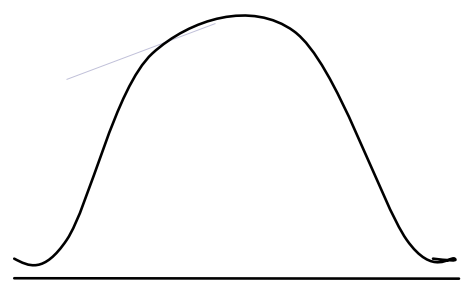

$\mathbf{R}(\mathbf{E})$

Fonte: Damodaran (2004, p. 156)

As empresas contratam as agências de classificação de riscos com o objetivo de divulgar o seu nível de risco ao mercado, funcionando como um sinalizador aos agentes de mercado, ou seja, analistas de investimentos e investidores. As instituições bancárias e investidores, antes de ceder crédito, necessitam conhecer o rating de uma empresa, porém, esse deve ser mensurado por uma empresa especializada e com total isenção, em que o produto final seja a obtenção de informações confiáveis e sintéticas garantindo, assim, maior nível de confiabilidade na transação e buscando menor assimetria de informação. Nesse sentido, opiniões independentes, geralmente disponibilizadas por agências classificadoras, também conhecidas como agências de rating, exercem papel fundamental para se medir o valor adicional do rendimento ou spread que o investidor deverá exigir, a fim de ser recompensado pelo risco potencial de crédito.

De acordo com análise de Altman et al. (2000, p. 3), é mais fácil desenhar um molde de um terno para um cliente que você já conhece. Com isso a gestão de risco de crédito continua a ser substancialmente uma atividade quase caseira, em que as decisões quanto a empréstimos são feitas sob medida, operação por operação, e as agências de classificação de crédito acabam auxiliando a gestão desse processo.

Conforme Securato (2002, p. 183): "classificar um crédito é, a partir de um conjunto de informações e de determinados parâmetros previamente selecionados, identificar 
em qual categoria de risco de crédito o cliente ativo ou potencial - pessoa jurídica ou física - se insere". O grau de risco é uma qualificação atribuída aos indicadores financeiros associados a informações de caráter puramente qualitativo, que indica com que severidade a empresa deverá ser tratada, tanto no momento do estabelecimento dos limites de crédito ou de aprovação de uma operação específica quanto no posterior gerenciamento do risco.

Em relação aos fatores qualitativos, são analisados:

- Características do setor e

- Posição competitiva da empresa.

\subsection{1 - Características do Setor}

Em várias situações, o desempenho do setor possui um papel preponderante sobre o perfil de risco da empresa. Portanto, devem ser analisadas as seguintes questões referentes ao setor: perspectiva de crescimento; grau de estabilidade; suscetibilidade a cenários macroeconômicos adversos e a ciclos econômicos; vulnerabilidade a mudanças tecnológicas e a interferências regulatórias; disponibilidade e fonte das matérias-primas requeridas; nível de investimento requerido em bens de capital e em pesquisa e desenvolvimento; grau de alavancagem operacional e natureza e intensidade da competição.

\subsection{2 - Posição Competitiva da Empresa}

Alguns fatores-chave de sucesso levam as empresas a serem bem sucedidas no setor e tais fatores são relacionados a seguir: perfil de seus acionistas e grau de suporte tecnológico e financeiro; market-share detido; eficiência operacional, associada à estrutura de custos; estado de conservação e grau de modernidade da planta industrial; disponibilidade e qualidade da mão-de-obra; tamanho ou capacidade instalada; grau de diversificação das atividades desenvolvidas, ou seja, diversificação para redução de risco; necessidade de novos investimentos e nível de recursos exigido; qualidade do gerenciamento e dos controles, das estratégias 
competitivas formuladas e das políticas de atuação da empresa e, sua aderência aos indicadores financeiros projetados.

A análise histórica do desenvolvimento do crédito elaborada por Barreto Filho (1975, p. 37) indica que, associada à aceitação do cheque como instrumento de crédito, a denominação inglesa Triple " $A$ " (ou três As) surgiu de uma declaração feita por Lloyd, na Inglaterra em 1840, afirmando que o "bilhete do banco deveria ser recebido a todo o momento, entre todas as pessoas e em todos os lugares" - "All the times, Between all persons and in all places". Com isso, o conceito Triple " $A$ " (AAA), muito utilizado por bancos, tem sido recentemente associado aos créditos que representam a menor probabilidade de inadimplência pelas agências de rating.

As agências de rating são organizações que fornecem serviços de análise, baseadas em informações disponíveis publicamente, embora informações particulares fornecidas pela empresa para a agência de rating tenham sua importância destacada, operando sob os princípios de independência, objetividade, credibilidade e disclosure.

Segundo a Moody's (2002, p. 48), as vantagens que uma empresa pode obter possuindo uma boa classificação de rating são destacadas como: menor valor de prêmio ou spread em suas operações; maior valorização de suas ações; maior atratividade de investimento externo; melhoria de imagem institucional; e maior facilidade na obtenção de empréstimos ou financiamentos.

\section{2 - O Processo de Classificação}

Conforme Damodaran (2004, p. 159), o processo de classificação do risco de crédito inicia-se quando uma empresa corporativa solicita a classificação a uma agência de rating. Essa, então, reúne informações de fontes disponíveis publicamente e demonstrações financeiras da própria empresa. A partir daí, toma uma decisão referente à classificação do rating. Caso a empresa discorde da classificação, ela poderá apresentar informações adicionais, visando à melhoria ou não da classificação. 
Como observado anteriormente, as classificações feitas por agências de rating utilizam o emprego de letras, ou seja, uma classificação "AAA" da Standard \& Poor's e "Aaa" da Moody's representam o mais alto nível classificatório, concedido a empresas com risco mais baixo de não pagamento. A medida que o risco de não pagamento aumenta, as classificações diminuem para " $D$ ", considerando-se que a empresa será inadimplente. Uma classificação acima de "BBB" da Standard \& Poor's é nivelada como investimento superior, refletindo a visão da agência de rating, que possui pouco risco de não pagamento ou risco de default.

Tanto a Moody's quanto a Standard \& Poor's utilizam indicadores para títulos classificados de Triple "A". A Standard \& Poor's utiliza um sistema de mais (+) e menos(-); assim, "A+" designa os títulos de classificação mais fortes e "A-" os mais fracos. A Moody's utiliza uma designação 1, 2 ou 3. Em que, 1 denota o mais forte e 3 o mais fraco. Em relação a categoria de duplo "A", "Aa1" é a melhor, "Aa2" é a média e "Aa3" é o mais fraco.

Segundo Hull (2002, p. 610), apenas títulos com rating "Baa" ou acima deste, são considerados com grau de investimento (investment grade). O autor, apresenta, ainda, o seguinte diagrama, evidenciando que quanto pior o rating maior será o spread sobre o título do Tesouro Americano.

\section{Gráfico 5 - Spread de Risco Sobre o Título do Tesouro Americano}

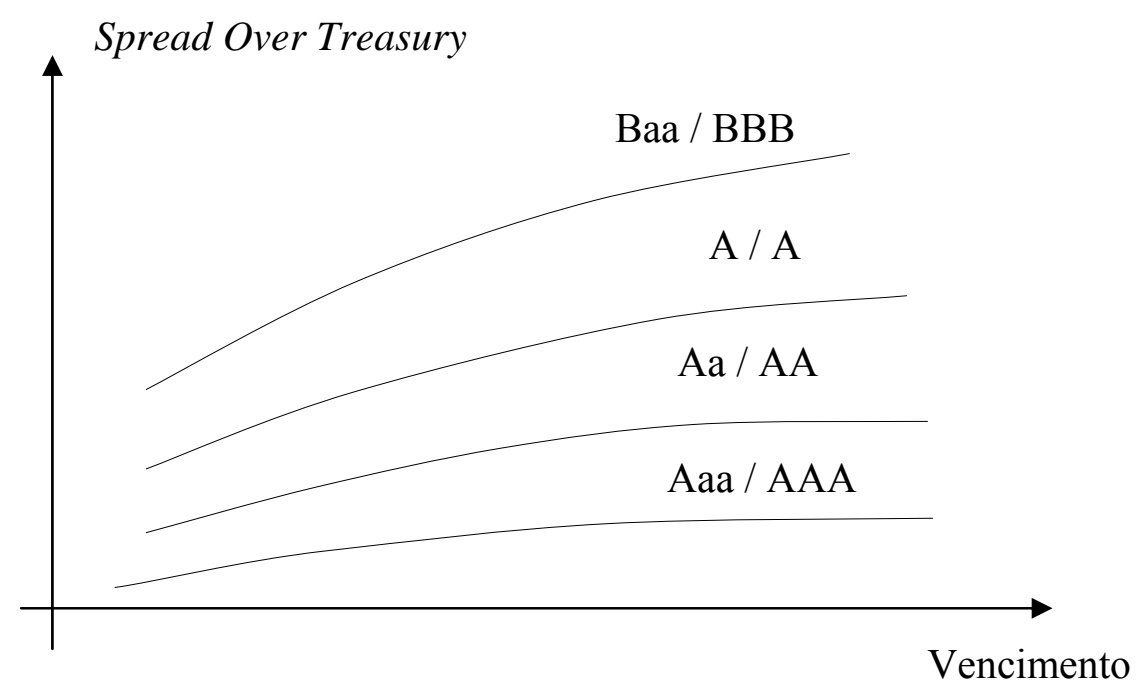

Fonte: Hull (2002, p. 611) 
De acordo com o esse gráfico demonstrado por Hull, percebe-se que quanto mais distante for o vencimento, maior será o spread sobre o título do Tesouro Americano, ou seja, o spread cresce acentuadamente com o aumento do vencimento para os títulos de rating de crédito menores.

O rating de crédito tornou-se uma medida de avaliação da qualidade do risco de crédito, utilizada para a tomada de decisão de investimentos tanto para títulos de renda fixa quanto para operações de empréstimos ou financiamentos. 
Figura 8 - Fluxograma do processo de classificação de rating de crédito
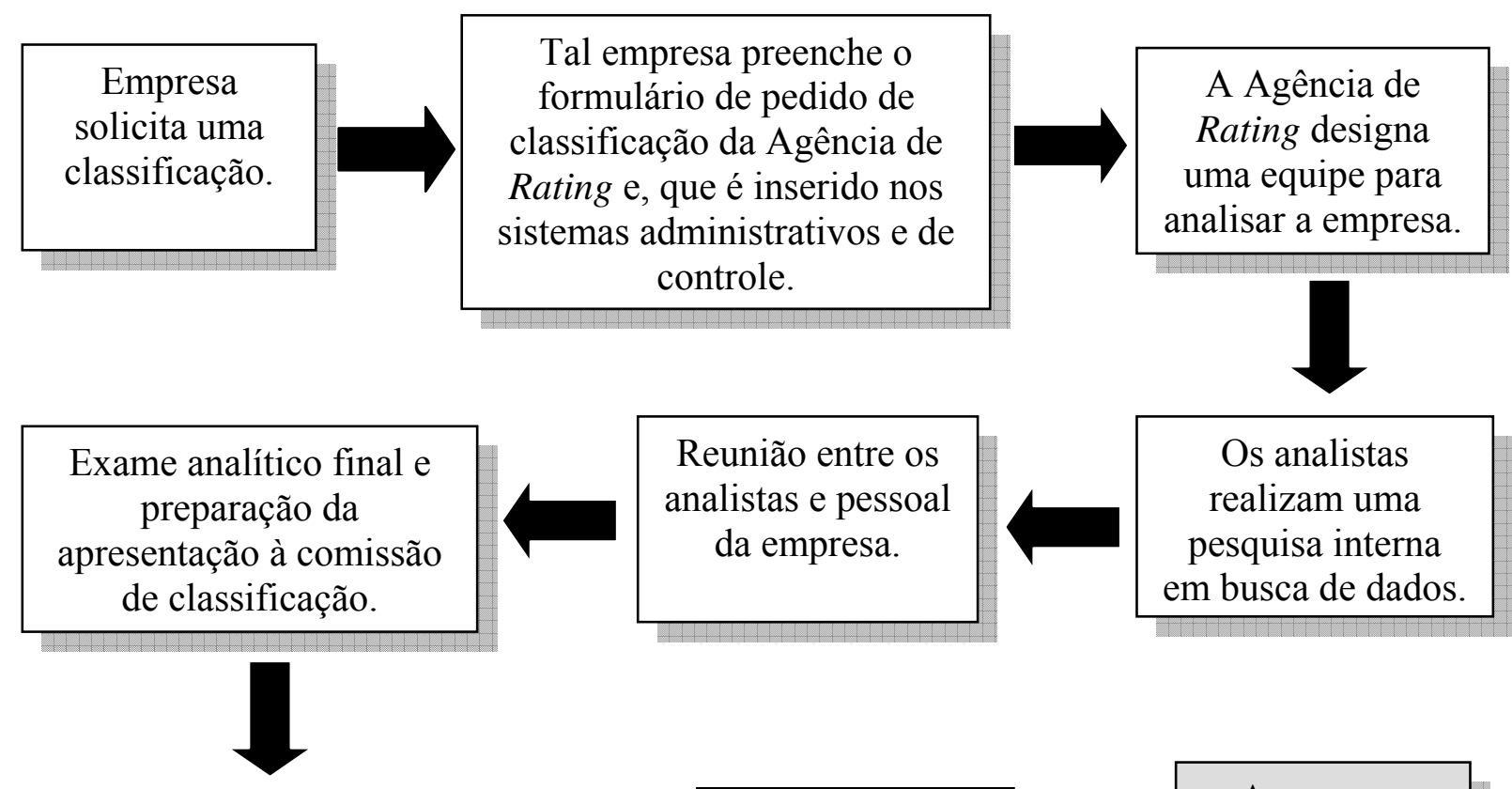

Apresentação da análise para o comitê de classificação da Agência de Rating e discussão e votação para determinar a classificação do crédito.

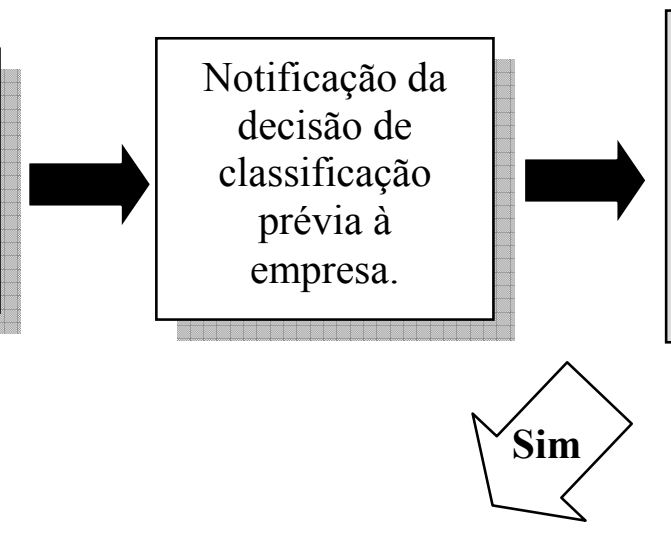

A empresa gostaria de fornecer informações adicionais?
Apresentação de informações adicionais à comissão de classificação da agência de rating.

Discussão e votação para confirmar ou modificar a classificação prévia.
Notificação formatada.

Classificação é tornada pública.

Fonte: Adaptada de Damodaran (2004, p. 159)

No decorrer do processo (conforme demonstrado na acima), são efetuadas due diligences (equivalentes à auditoria), que são visitas às empresas em que se observam aspectos administrativos, operacionais, tecnológicos, mercadológicos e estratégicos. Ao final da fase de apuração das informações, essas são compiladas 
em um relatório preliminar desenvolvido pela equipe de analistas da due diligence. Esse relatório preliminar é apresentado pelos analistas responsáveis aos membros do comitê de classificação. A partir da reunião da comissão de classificação, são atribuídas notas que variam de acordo com as diversas escalas de classificação existentes.

Após a atribuição da nota, o relatório preliminar é encaminhado à empresa analisada. A partir desse relatório, são feitos comentários, sugestões, apelações ou esclarecimentos. As reivindicações do cliente são encaminhadas pelo analista responsável ao comitê que julga sua procedência podendo ou não, com base em informações adicionais, alterar a nota inicialmente estabelecida.

Ao final desse processo, caso a empresa a ser analisada autorize, a nota é publicada e inicia-se o processo de monitoramento, ou seja, os ratings divulgados pelas agências são monitorados constantemente, incorporando novas informações à medida que se tornam disponíveis. Além disso, é usual realizar-se uma due diligence anual às empresas que passaram por processo de avaliação.

Segundo Securato (2002, p. 184), a classificação de risco é uma opinião sobre a capacidade futura, a responsabilidade jurídica e vontade do tomador do empréstimo de efetuar, dentro do prazo acordado, o pagamento de juros e principal das obrigações por ele assumidas.

Essa classificação avalia a probabilidade de default do tomador do empréstimo, com base no histórico de inadimplência (armazenados pelas agências de rating) das empresas e no seu perfil.

Conforme demonstrado na figura a seguir, por meio de seu banco de dados, a Moody's é capaz de verificar que, em média, apenas 0,2\% dos devedores com classificação "Aaa" (a maior nota atribuída por essa agência de rating) tornaram-se inadimplentes em um período de 5 anos e, em um período de 10 anos, pouco mais de $1 \%$. Em média, cerca de $21 \%$ dos tomadores, com classificação "B", tornaram-se inadimplentes após 5 anos e $32 \%$ após 10 anos: 
Gráfico 6 - Taxa Média de Inadimplência após 5, 10, 15 e 20 anos

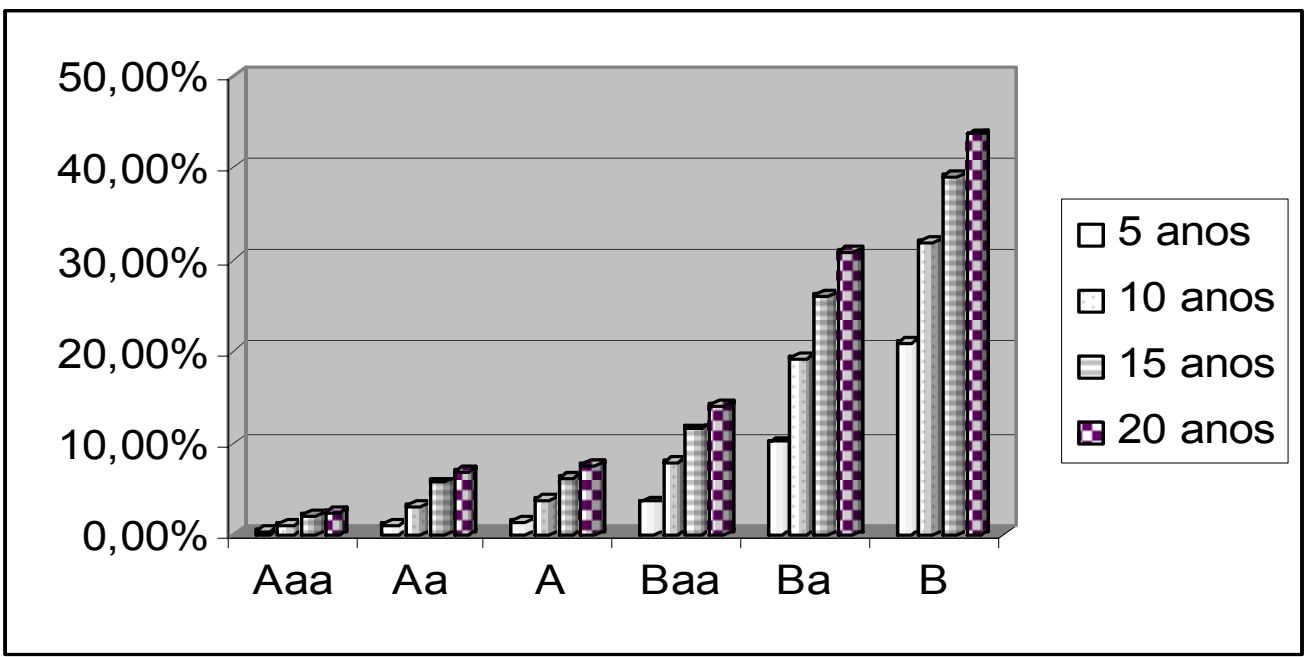

\begin{tabular}{|c|cccccc|}
\cline { 2 - 7 } \multicolumn{1}{c|}{} & Aaa & Aa & A & Baa & Ba & B \\
\hline $\mathbf{5}$ anos & $0,20 \%$ & $0,97 \%$ & $1,37 \%$ & $3,51 \%$ & $10,04 \%$ & $20,88 \%$ \\
anos & $1,09 \%$ & $3,10 \%$ & $3,61 \%$ & $7,92 \%$ & $19,05 \%$ & $31,89 \%$ \\
\hline $\mathbf{1 5}$ anos & $1,89 \%$ & $5,61 \%$ & $6,13 \%$ & $11,46 \%$ & $25,95 \%$ & $39,15 \%$ \\
\hline $\mathbf{2 0}$ anos & $2,38 \%$ & $6,75 \%$ & $7,47 \%$ & $13,95 \%$ & $30,82 \%$ & $43,69 \%$ \\
\hline
\end{tabular}

Fonte: Moody's Investor Service (1999, p. 85)

O rating de crédito informa a probabilidade de uma empresa não saldar o empréstimo obtido dentro do prazo esperado, isto é, a probabilidade de tornar-se inadimplente. Pode-se, por exemplo, utilizar a tabela, a seguir, como parâmetro, conforme a probabilidade de default de uma empresa: 
Tabela 2 - Probabilidade de default de uma empresa

\begin{tabular}{|c|c|}
\hline Rating & $\begin{array}{c}\text { Probabilidade de } \\
\text { Default }\end{array}$ \\
\hline Aaa & $0,00 \%$ \\
\hline Aa1 & $0,02 \%$ \\
\hline Aa2 & $0,05 \%$ \\
\hline Aa3 & $0,10 \%$ \\
\hline A1 & $0,19 \%$ \\
\hline A2 & $0,35 \%$ \\
\hline A3 & $0,54 \%$ \\
\hline Baa1 & $0,83 \%$ \\
\hline Baa2 & $1,20 \%$ \\
\hline Baa3 & $2,38 \%$ \\
\hline Ba1 & $4,20 \%$ \\
\hline Ba2 & $6,80 \%$ \\
\hline Ba3 & $9,79 \%$ \\
\hline B1 & $13,85 \%$ \\
\hline B2 & $18,13 \%$ \\
\hline B3 & $24,04 \%$ \\
\hline Caa1 & $32,86 \%$ \\
\hline Caa2 & $43,88 \%$ \\
\hline Caa3 & $66,24 \%$ \\
\hline
\end{tabular}

Fonte: Moody's Investors Service (2002, p. 4) 
De acordo com Damodaran (2004, p.158), o risco de inadimplência de uma empresa é uma função de duas variáveis: a primeira diz respeito à capacidade da empresa de gerar fluxos de caixa sobre operações e a segunda diz respeito às obrigações financeiras ou obrigações onerosas, ou seja, obrigações incluindo pagamentos do principal e de juros. Empresas que possuem elevados fluxos de caixa em relação às suas obrigações financeiras tendem a possuir um risco de inadimplência menor do que as empresas com baixa geração de fluxos de caixa.

O fluxo de caixa sobre operações é também conhecido por fluxo de caixa operacional livre, que é igual aos lucros operacionais após os impostos da empresa, menos desembolsos de capital e menos variações no capital de giro.

Logo, o índice financeiro usado para mensurar o risco de inadimplência é:

$$
\frac{\text { Fluxode caixa operacional livre }}{\text { Dívida total }}=
$$

Lucro operacional - Desembolsos de capital - Variação no capital de giro

Dívida total

Fonte: Adaptado de Damodaram (2004, p. 160)

Após analisados todos os fatores que podem influenciar o rating, as empresas avaliadas recebem uma classificação que varia de "AAA" ou "Aaa" para segurança máxima nos recebimentos, até " $D$ " que inclui empresas em processo de recuperação judicial (antiga concordata) ou falência. 
A tabela, a seguir, compara a classificação de risco usada pelas três maiores agências de classificação de risco internacionais, ou seja, Standard \& Poor's, Moody's e Fitch:

Tabela 3 - Classificação de risco da Standard \& Poor's, Moody's e Fitch

\begin{tabular}{|c|c|c|c|}
\hline \multirow{2}{*}{ Explicação sobre Rating } & \multicolumn{3}{|c|}{ Serviço de Rating } \\
\hline & $\begin{array}{l}\text { Standard } \\
\text { \& Poor's }\end{array}$ & Moody's & Fitch \\
\hline Segurança Máxima & AAA & Aaa & AAA \\
\hline \multirow{3}{*}{ Alta Segurança } & $\mathrm{AA}+$ & Aa1 & $\mathrm{AA}+$ \\
\hline & AA & $\mathrm{Aa} 2$ & AA \\
\hline & AA- & Aa3 & AA- \\
\hline \multirow{3}{*}{ Segurança Média Alta } & $\mathrm{A}+$ & A1 & $\mathrm{A}+$ \\
\hline & A & $\mathrm{A} 2$ & $\mathrm{~A}$ \\
\hline & A- & A3 & A- \\
\hline \multirow{3}{*}{ Segurança Média Baixa } & $\mathrm{BBB}+$ & Baal & $\mathrm{BBB}+$ \\
\hline & BBB & Baa2 & BBB \\
\hline & BBB- & Baa3 & BBB- \\
\hline \multicolumn{4}{|c|}{ Investment Grade } \\
\hline \multirow{3}{*}{ Especulativo } & $\mathrm{BB}+$ & Ba1 & $\mathrm{BB}+$ \\
\hline & $\mathrm{BB}$ & $\mathrm{Ba} 2$ & $\mathrm{BB}$ \\
\hline & BB- & $\mathrm{Ba} 3$ & BB- \\
\hline \multirow{3}{*}{ Altamente Especulativo } & $\mathrm{B}+$ & B1 & $\mathrm{B}+$ \\
\hline & $\mathrm{B}$ & B2 & $\mathrm{B}$ \\
\hline & B- & B3 & B- \\
\hline Risco de Insolvência & $\mathrm{CCC}$ & Caa & $\mathrm{CCC}$ \\
\hline Risco Substancial & $\mathrm{CC}$ & $\mathrm{Ca}$ & $\mathrm{CC}$ \\
\hline Probabilidade de Insolvência & $\mathrm{C}$ & $\mathrm{C}$ & $\mathrm{C}$ \\
\hline \multirow{3}{*}{ Alto risco de Insolvência } & DDD & & DDD \\
\hline & DD & & DD \\
\hline & $\mathrm{D}$ & & $\mathrm{D}$ \\
\hline
\end{tabular}

Fonte: Standard \& Poor's, Fitch Ibca e Moody's 
Os investidores e gestores de fundos, em geral, utilizam os ratings para a tomada de decisão de compra dos títulos para as suas carteiras, porém, existe a possibilidade de alterações nas classificações de ratings efetuados pelas empresas de rating de crédito, em função de possíveis mudanças das perspectivas atribuídas aos ratings atuais. Tais alterações poderão provocar revisões dos ratings por meio da ocorrência das respectivas descrições da tabela a seguir:

Tabela 4 - Revisões dos ratings por meio de ocorrências

\begin{tabular}{|c|c|c|}
\hline Perspectiva & Rating & Simbologia \\
\hline Positiva & $\begin{array}{c}\text { Pode ser } \\
\text { elevado }\end{array}$ \\
\hline Negativa & $\begin{array}{c}\text { Pode ser } \\
\text { rebaixado }\end{array}$ \\
\hline Estável & Alteração pouco \\
provável & \\
\hline
\end{tabular}

Fonte: Moody's Investor Service (1999, p. 78)

\section{3 - Descrição da Metodologia de Rating da Fitch Rating}

A Fitch Ratings foi fundada em dezembro de 1913 por John Knowles Fitch, por meio da publicação de estatísticas financeiras de empresas de consumo e que passaram a ser utilizadas pela comunidade financeira da cidade de New York. Publicou, também, Fitch Bond Book e Fitch Stock and Bond Manual. Desde, então, a Fitch Ratings vem crescendo por meio de aquisições de empresas de rating possuindo, atualmente, mais de 49 escritórios espalhados pelo mundo.

A Fitch Ratings começou a operar no mercado brasileiro no início da década de 80, tendo estabelecido uma subsidiária local, em 1997, que sucedeu o escritório de representação e passou a atribuir, também, ratings nacionais aos bancos e empresas brasileiras. Em abril de 2003, a Fitch adquiriu à Atlantic Rating a maior 
agência nacional de rating, com atuação no Brasil, desde 1992. A fusão das duas empresas originou a agência de classificação de risco líder no mercado nacional.

De acordo com a Fitch Ratings (2004, p. 57), a metodologia utilizada tem como objetivo emitir um parecer sobre a capacidade da empresa analisada pagar o principal e juros no período pré-determinado. Esse parecer será estabelecido mediante o processo adotado de forma a coletar da empresa corporativa todas as informações necessárias para estabelecer o rating de crédito.

As informações fornecidas pela empresa são tanto quantitativas quanto qualitativas e serão utilizadas para a elaboração do rating de crédito.

A análise qualitativa deve abordar os seguintes tópicos: risco da indústria; ambiente operacional; gestão, posicionamento de mercado e contabilidade.

Basicamente, os ratings de crédito da Fitch Ratings constituem uma opinião quanto às condições de uma empresa corporativa honrar seus compromissos financeiros, tais como pagamentos de juros, dividendos e de pagamento do principal, no prazo pré-estabelecido. Os ratings de crédito da Fitch Ratings são também aplicáveis a uma variedade de emissores: países, estados, municípios, operações estruturadas e instituições financeiras podendo, inclusive, medir a capacidade de empresas seguradoras e garantidores honrarem suas obrigações.

As informações mais importantes para a elaboração do rating de crédito dizem respeito a estratégias empresariais; estratégias de aquisições; estrutura organizacional; operações da empresa; perspectivas de mercado; posição competitiva; estratégias financeiras; lucratividade; capacidade de geração de fluxo de caixa; estrutura de capital; liquidez financeira e procedimentos de gerenciamento do risco operacional.

As empresas que obtêm o mesmo rating de crédito apresentam qualidade de crédito similar, mas, não necessariamente idêntica, pois as categorias de rating não refletem as pequenas diferenças relacionadas aos graus de risco de crédito. 
O ratings de crédito, conforme a Fitch Ratings (2004, p. 45), não constituem recomendação de compra, venda ou manutenção de um título. O rating é atribuído baseado em informações obtidas junto às empresas analisadas, além de outros devedores, underwriters, consultores e outras fontes que a Fitch Rating julgue fidedignas. Não é atribuição da Fitch Rating realizar a tarefa de auditoria ou mesmo a verificação de as informações analisadas serem verdadeiras ou exatas. O rating pode ser mudado ou descontinuado como resultado de alterações nas informações, sua indisponibilidade, ou por outras razões.

\section{Tabela 5 - Relação das informações analisadas pela Fitch Rating}

\begin{tabular}{|c|l|}
\hline Itens Analisados & \multicolumn{1}{|c|}{ Avaliações } \\
\hline Fluxo de caixa & Como é utilizado o recurso \\
& Estrutura de Capital \\
& Medidas para manter a estabilidade da receita \\
& Medidas para manter o fluxo de caixa \\
& Provisões e reservas de contingências \\
\hline \multirow{5}{*}{ Politicas da Contabilidade } & Avaliação dos demonstrativos financeiros \\
& Fechamento de balanço \\
& Indicadores de lucratividade \\
& Metodologia de custos \\
& Metodologia de depreciação \\
& Política de avaliação contábil \\
& Práticas de reconhecimento de rendas e \\
& reservas \\
& Princípios de consolidação das contas \\
& Provisões \\
\hline \multirow{5}{*}{ Gerenciamento da Empresa } & Estratégias de aquisições \\
& Existência de estratégias empresariais \\
& Flexibilidade financeira \\
& Foco da empresa direcionado para as metas \\
& O perfil do gestor em assumir riscos \\
\hline \multirow{2}{*}{ Ambiente Operacional } & Capacidade da empresa em influenciar os \\
& preços \\
\hline \multirow{5}{*}{ Posicionamento de Mercado } & Capacidade da empresa para resistir às \\
& pressões competitivas \\
& Diversificação de produtos \\
& Lucro das vendas por área de atuação \\
& Posicionamento de custos \\
& Tamanho da empresa \\
\hline & Existência de oportunidades e ameaças \\
& Medidas de proteção à lucratividade \\
& Existência de ciclos de volatilidade \\
& Grau de crescimento da indústria \\
& Necessidade de utilização de capital \\
& Nivel de competitividade \\
\hline & \\
&
\end{tabular}

Fonte: Fitch Ibca, Duff\&Phelps (2001, p. 54) 
Conforme demonstrado na tabela apresentada, a base da metodologia da Fitch Rating para a classificação de rating de crédito consiste na análise dos seguintes itens: fluxo de caixa; políticas da contabilidade; gerenciamento da empresa; posicionamento de mercado; ambiente operacional e risco da indústria. Os dados financeiros, descritos no fluxo de caixa e políticas da contabilidade possuem uma relevância no resultado do rating de crédito.

\section{4 - Descrição da Metodologia de Rating da Standard \& Poor's}

A Standard \& Poor's foi fundada em 1860, quando Henry Varnum Poor publicou a história das Ferrovias e Canais dos EUA (history for railroads and canals of the United States) com a finalidade de publicar informações financeiras e prestar serviços de pesquisa alicerçadas no seguinte princípio "o investidor tem o direito de saber". Atualmente, a Standar\& Poor's é a maior provedora global de dados, avaliações e opiniões independentes sobre investimentos e sua metodologia visa a diagnosticar a probabilidade de ocorrência de falta de pagamento pela empresa avaliada. Geralmente, os ratings de emissões de títulos com distribuição pública são monitorados durante, pelo menos, três anos.

A Standard \& Poors é uma organização que elabora ratings, ou seja, opiniões sobre a qualidade creditícia de empresas emissoras de títulos e valores mobiliários no mercado de capitais, e trabalha com os seguintes princípios indicados na figura a seguir: 
Figura 9 - Princípios para se atingir qualidade creditícia

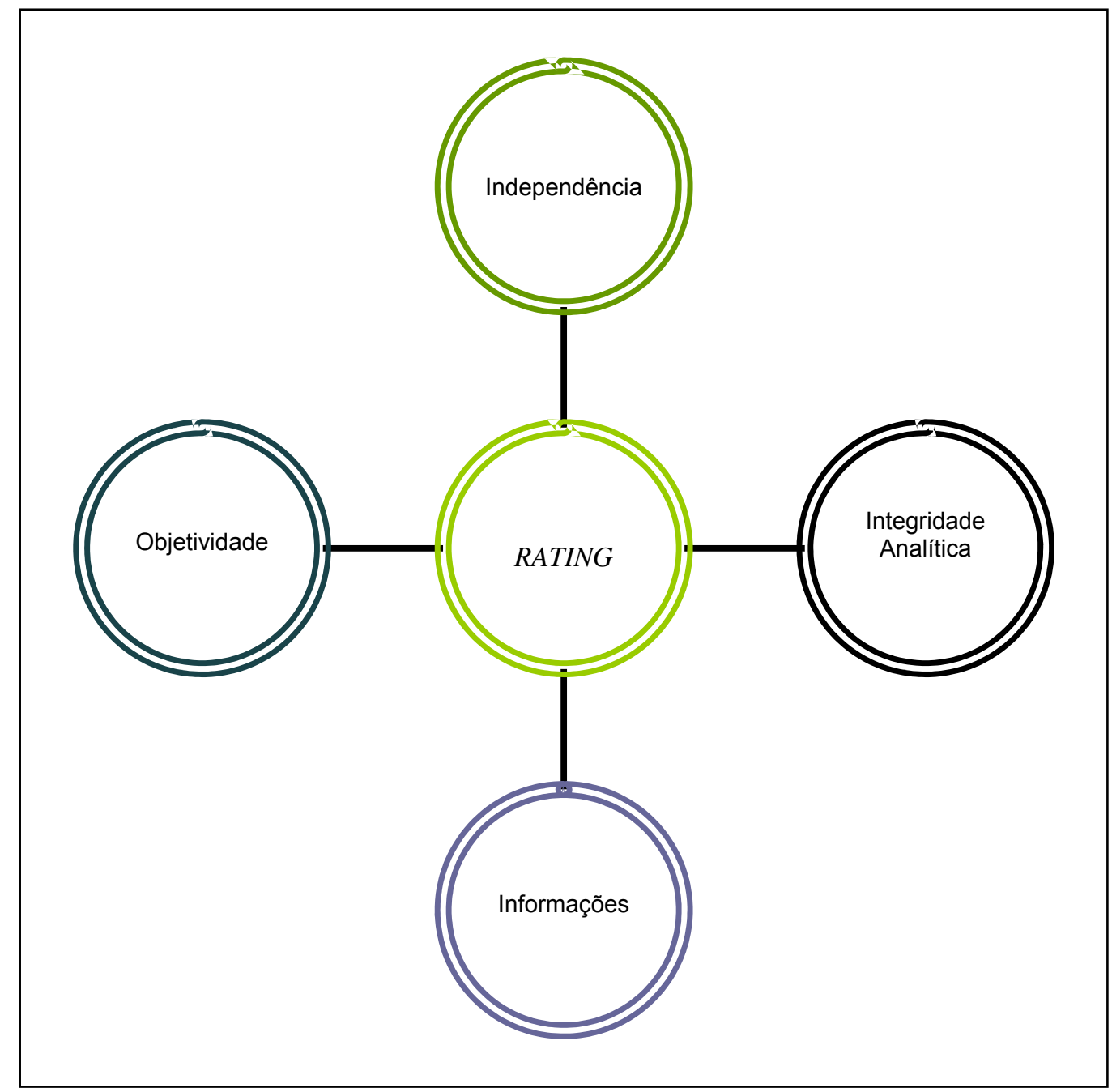

Fonte: Standard \& Poors (2003, p. 1)

Conforme demonstrado nessa figura, nos princípios para se atingir qualidade creditícia utilizado pela Standard \& Poors, percebe-se que, o rating de crédito é estabelecido de acordo, com variáveis decisivas para a boa prática de governança corporativa e consequentemente, a recompensa pela transparência e qualidade das informações. Essa recompensa é traduzida como, taxas de financiamentos menores. 
Ainda conforme a Standard \& Poor's (2003, p. 3), o padrão de metodologia de rating para realizar a avaliação da qualidade de crédito segue a análise do risco do setor ao qual a empresa pertence, bem como sua posição competitiva, associadas à análise do seu perfil financeiro e suas políticas, desde que essas informações estejam disponíveis. Os ratings são baseados em informações fornecidas pelas empresas que estão sendo analisadas ou obtidas pela Standard \& Poor's por outras fontes de sua confiança.

A metodologia analítica da Standard \& Poor's para a análise do rating de crédito das empresas é focada em dois componentes principais, ou seja, o primeiro está direcionado à análise dos fundamentos do negócio, e também à posição competitiva da empresa, e o segundo componente possui um foco na análise funcional, ou seja, na avaliação de seu corpo administrativo e de suas estratégias.

Geralmente, as análises são baseadas em indicadores e resultados históricos dos últimos cinco anos, bem como na projeção de resultados em um horizonte futuro de dois ou três anos.

O rating de crédito final é uma síntese dos fatores quantitativos e qualitativos analisados e discutidos por um comitê de analistas especialistas do setor ao qual a empresa corporativa analisada pertence.

De acordo com a Standard \& Poor's (2002, p.1) os ratings de emissões de empresas são baseados nas seguintes considerações:

1. Probabilidade de pagamento ou capacidade e vontade da empresa emissora de honrar seus compromissos financeiros, de acordo com os termos definidos pela obrigação assumida;

2. Natureza e provisões das obrigações e

3. Proteção dada pela obrigação, no caso de falência, reorganização e outros acordos previstos pela lei de falência, ou outras leis que possam afetar os direitos do credor, bem como sua posição relativa a outras obrigações contraídas pela empresa emissora. 
$\mathrm{Na}$ tabela a seguir, estão dispostos os itens a serem analisados pela equipe de analistas da Standard \& Poor's:

Tabela 6 - Relação das informações analisadas pela Standard \& Poor's

\begin{tabular}{|c|c|}
\hline Itens Analisados & Avaliações \\
\hline Características e Risco do Setor & $\begin{array}{l}\text { O ambiente e as perspectivas de crescimento, } \\
\text { estabilidade ou declínio. } \\
\text { O padrão dos ciclos de negócios. } \\
\text { Vulnerabilidade às mudanças tecnológicas, } \\
\text { questões trabalhistas, ou interferências } \\
\text { regulatórias. } \\
\text { Níveis de intensidade do capital fixo ou de giro. } \\
\text { Necessidades de gastos atuais com ativo ou } \\
\text { com pesquisa e desenvolvimento. } \\
\text { A natureza e a intensidade do ambiente } \\
\text { competitivo. } \\
\text { Análise específica de sua composição } \\
\text { geográfica e de seus negócios. } \\
\text { Os fatores relativos à oferta e à demanda } \\
\text { doméstica e mundial. }\end{array}$ \\
\hline Posição Competitiva & $\begin{array}{l}\text { Participação no mercado. } \\
\text { Eficiência operacional. } \\
\text { Tamanho. } \\
\text { Diversificação. } \\
\text { Qualidade do corpo administrativo. }\end{array}$ \\
\hline Risco Financeiro & $\begin{array}{l}\text { Estrutura de capital. } \\
\text { As demonstrações financeiras são } \\
\text { consolidadas? } \\
\text { Riscos cambiais - flutuação da moeda. } \\
\text { Controle familiar por meio de um grupo. } \\
\text { Potenciais controles de preços. } \\
\text { Efeitos da Inflação sobre os preços praticados. }\end{array}$ \\
\hline $\begin{array}{l}\text { Qualidade da Contabilidade e } \\
\text { Análise dos Dados }\end{array}$ & $\begin{array}{l}\text { Base de consolidação. } \\
\text { Reconhecimento da receita. } \\
\text { Depreciação. } \\
\text { Reservas para indenizações de funcionários e } \\
\text { planos de pensão. } \\
\text { Conversão para moedas estrangeiras. } \\
\text { Avaliação de inventário. } \\
\text { Obrigações fora do orçamento, incluindo } \\
\text { arrendamentos, financiamentos, dívidas } \\
\text { garantidas pelo emissor que não são } \\
\text { consolidadas e dívidas de controladas e } \\
\text { afiliadas. } \\
\text { Provisões de impostos, descontos e } \\
\text { obrigações futuras. }\end{array}$ \\
\hline
\end{tabular}




\begin{tabular}{|c|c|}
\hline Política Financeira & $\begin{array}{l}\text { Métodos de avaliação do desempenho da } \\
\text { diretoria financeira. } \\
\text { Relacionamento bancário. } \\
\text { Tratamento dos impostos sobre juros e } \\
\text { dividendos. } \\
\text { Políticas de aquisições. } \\
\text { Planos de investimentos. }\end{array}$ \\
\hline Rentabilidade & $\begin{array}{l}\text { Retorno sobre o capital. } \\
\text { Margens de lucros. } \\
\text { Lucros sobre os ativos do segmento de } \\
\text { negócio. } \\
\text { Índice de cobertura dos juros. }\end{array}$ \\
\hline $\begin{array}{l}\text { Alavancagem Financeira e } \\
\text { Proteção dos Ativos }\end{array}$ & $\begin{array}{l}\text { Financiamento da dívida. } \\
\text { Mix de dívidas (taxas fixas e flutuantes). } \\
\text { Posição de liquidez (nível de capital de giro). } \\
\text { Natureza dos empréstimos. } \\
\text { Revaloração dos ativos. }\end{array}$ \\
\hline Adequação do Fluxo de Caixa & $\begin{array}{l}\text { Necessidade de capital para ativos fixos e } \\
\text { capital de giro. } \\
\text { Índices de pagamento de dividendos. } \\
\text { Índices de fluxo de caixa, após o pagamento } \\
\text { de impostos. }\end{array}$ \\
\hline Flexibilidade Financeira & $\begin{array}{l}\text { Capacidade de cumprir seu programa de } \\
\text { financiamento, durante períodos de } \\
\text { adversidade econômica. } \\
\text { Acesso rápido ao financiamento bancário. } \\
\text { Acesso ao mercado de capitais - títulos de } \\
\text { dívida e ações. } \\
\text { Acesso às fontes externas de financiamento. }\end{array}$ \\
\hline Blocos Locais de Propriedade & $\begin{array}{l}\text { Benefícios de relacionamentos operacionais ou } \\
\text { maior acesso a financiamentos. } \\
\text { Responsabilidade direta ou indireta de fornecer } \\
\text { apoio a empresas mais fracas do grupo. }\end{array}$ \\
\hline
\end{tabular}

Fonte: Adaptado de Standard \& Poor's (2000, p. 21) 
Conforme demonstrado na tabela apresentada, a base da metodologia da Standard \& Poor's para a classificação de rating de crédito consiste na análise mais detalhada dos seguintes itens: Características e Risco do Setor; Posição Competitiva; Blocos Locais de Propriedade; Política Financeira e, principalmente, do Risco Financeiro; Qualidade da Contabilidade e Análise dos Dados; Rentabilidade, Alavancagem Financeira e Proteção dos Ativos; Adequação do Fluxo de Caixa, e Flexibilidade Financeira. Os dados financeiros, descritos na alavancagem financeira e rentabilidade, possuem uma relevância no resultado do rating de crédito.

\section{5 - Descrição da Metodologia de Rating da Moody's}

De acordo com a própria Moody's (1999, p. 2), John Moody introduziu ratings no mercado norte-americano de títulos de dívida, em 1909, quando foram publicados os primeiros ratings de dívida no Manual de Títulos de Dívida Ferroviários. John Moody iniciava no setor de análise de ações e bônus das companhias ferroviárias dos EUA e, com essa iniciativa, tornou-se o primeiro a classificar títulos e valores mobiliários lançados publicamente no mercado.

Os ratings da Moody's são indicadores ou probabilidade do potencial de perda de crédito, ou seja, o diferencial entre o que a empresa assumiu como dívida e o que foi efetivamente liquidado. Os ratings da Moody's medem a perda efetiva de crédito, incluindo tanto a probabilidade de uma empresa corporativa entrar em default como o grau de probabilidade esperada depois que um default ocorre.

Os ratings da Moody's são determinados inicialmente por comitês, que incluem um diretor gerente ou outro profissional designado e o analista líder, para analisar as informações já contidas nos relatórios da empresa, bem como coletar formalmente junto à empresa, quando houver necessidade de outras informações qualificadas, e analisá-las integralmente para o processo final de rating de crédito. 
Esse processo de rating de crédito da Moody's reúne informações suficientes para se avaliar o risco dos investidores que possam adquirir ou comprar um determinado título da empresa analisada, ou seja, vários investidores e gestores de fundos utilizam o rating para determinar se um determinado título é adequado ao perfil de risco de sua carteira. A Moody's desenvolve uma conclusão em comitê sobre o rating apropriado; monitora continuamente para determinar se o rating deve ser alterado e informa ao mercado e seus participantes sobre as ações que deverá tomar.

Conforme destacado na Moody's (1999, p. 3), a base da sua metodologia para a classificação de dívida de empresas no mundo inteiro se apóia em duas questões principais: a primeira é o risco de o detentor da dívida (investidor) não receber pontualmente o pagamento do principal e dos juros dessa dívida, ou seja, o rating de crédito estará medindo a capacidade de uma empresa gerar caixa no futuro. A segunda é a comparação entre o nível de risco da empresa e o nível de risco das demais oportunidades de investimento disponíveis no mercado financeiro, seja por meio de títulos ou empréstimos.

O foco principal da análise da Moody's é a determinação da previsibilidade da geração futura de caixa, que é construída sobre uma cuidadosa análise da empresa, tanto dos seus pontos fortes quanto dos seus pontos fracos comparando-se com as demais empresas do mesmo setor mundial, bem como com um exame de fatores externos à empresa, tais como tendências de setor ou de país que possam influenciar negativamente a capacidade da empresa de cumprir suas obrigações de dívida de curto e longo prazos.

De acordo com a Moody's (1998, p. 3), "a qualidade de crédito é algo dinâmico e não estático", ou seja, após a análise de classificação de rating de crédito de uma empresa, os analistas da Moody's permanecem com o sentimento de responsabilidade perante $\mathrm{o}$ investidor por fornecer opiniões de classificação continuamente, ou seja:

1. Monitoramento das classificações;

2. Anúncio de qualquer alteração na perspectiva para a classificação; 
3. Proposta de medidas apropriadas de rating para o respectivo comitê de classificação da Moody's, quando os analistas acreditam que uma alteração seja necessária e

4. Sinalização para o mercado das alterações ocorridas, conforme decisão do comitê de classificação.

As revisões das classificações são necessárias para uma possível atualização para cima, para baixo, ou com direção incerta em qualquer dos vários cenários descritos a seguir:

1. A empresa analisada divulgou planos que poderão afetar de forma substancial, a qualidade de crédito, embora não exista uma certeza da sua realização. $A$ direção da revisão da classificação do rating para cima ou para baixo indica a opinião do comitê de analistas: como esse crédito poderia ser afetado, positivamente ou negativamente, caso esses planos ocorram;

2. A possibilidade de surgimento de tendências nas operações ou qualidade financeira da empresa analisada, em seu setor ou nos fundamentos macroeconômicos de seu país, que possam afetar - positivamente ou negativamente - a disposição e a capacidade da empresa saldar suas dívidas pontualmente e

3. Ocorrência repentina de evento que possa alterar o ambiente operacional da empresa, não se certificando da magnitude de seu efeito. E nesse caso, a revisão se concentrará em classificação atual inadequada, devido à provável alteração da classificação (rating). 
Tabela 7 - Relação das informações analisadas pela Moody's

\begin{tabular}{|c|c|}
\hline Itens Analisados & Avaliações \\
\hline Tendências do Setor & $\begin{array}{l}\text { Vulnerabilidade a ciclos econômicos. } \\
\text { Preços de commodities globalizados. } \\
\text { Concorrência interna e global. } \\
\text { Barreiras à entrada. } \\
\text { Fatores de custo. } \\
\text { Vulnerabilidade a alterações tecnológicas. }\end{array}$ \\
\hline $\begin{array}{l}\text { Ambiente Nacional Político } \\
\text { e Regulatório }\end{array}$ & $\begin{array}{l}\text { Práticas de negócios do país de origem. } \\
\text { Tendências regulatórias e desregulatórias. } \\
\text { Garantias e apoio governamentais. } \\
\text { Política monetária e taxas de câmbio. }\end{array}$ \\
\hline $\begin{array}{l}\text { Qualidade da } \\
\text { Administração }\end{array}$ & $\begin{array}{l}\text { Direção estratégica. } \\
\text { Filosofia financeira. } \\
\text { Conservadorismo. } \\
\text { Desempenho passado. } \\
\text { Relação matriz-subsidiária. } \\
\text { Planejamento sucessório. } \\
\text { Sistema de controle. }\end{array}$ \\
\hline $\begin{array}{l}\text { Posição Operacional e } \\
\text { Competitiva Básica }\end{array}$ & $\begin{array}{l}\text { Perspectiva de participação de mercado relativa. } \\
\text { Diversificação por linhas de negócios e por fluxos } \\
\text { de receitas. } \\
\text { Estrutura de custos. }\end{array}$ \\
\hline $\begin{array}{l}\text { Situação Financeira e } \\
\text { Fontes de Liquidez }\end{array}$ & $\begin{array}{l}\text { Avaliando a flexibilidade financeira } \\
\text { Avaliação da importância crítica de liquidez de } \\
\text { apoio. } \\
\text { Avaliação da necessidade relativa de fontes de } \\
\text { apoio. } \\
\text { Avaliação da qualidade de linhas de apoio. } \\
\text { Avaliação da fonte. } \\
\text { Cronometragem de recursos disponíveis. } \\
\text { Valores mobiliários como liquidez alternativa. } \\
\text { Uso de securitização em planejamento de liquidez } \\
\text { alternado. }\end{array}$ \\
\hline Estrutura da Empresa & $\begin{array}{l}\text { Importância da subsidiária para a entidade global. } \\
\text { Situação financeira relativa. } \\
\text { Ambiente jurídico. } \\
\text { Sócios de joint ventures e acordos de cooperação. } \\
\text { Subordinação estrutural e prioridade de } \\
\text { reivindicação. } \\
\text { Cláusulas contratuais. }\end{array}$ \\
\hline Garantias da Matriz & $\begin{array}{l}\text { Garantias da matriz. } \\
\text { Contratos de manutenção. } \\
\text { Exeqüibilidade e pontualidade de pagamento. } \\
\text { Termos e condições do contrato. }\end{array}$ \\
\hline Risco de Evento Especial & $\begin{array}{l}\text { Evento especial adverso. } \\
\text { Redução de riscos de eventos. }\end{array}$ \\
\hline
\end{tabular}

Fonte: Moody's Investors Service (1999, p. 4) 
Conforme apresentado na tabela anterior, para uma avaliação da capacidade isolada da empresa de amortizar suas obrigações de principal e juros, a Moody's realiza uma investigação nas seguintes áreas: tendências do setor; ambiente nacional político e regulatório; qualidade da administração; posição operacional e competitiva básica; estrutura da empresa; garantias da matriz e contratos de manutenção; risco de evento especial e, principalmente, a situação financeira e fontes de liquidez que possuem relevância no resultado do rating de crédito.

\section{6 - Síntese das Metodologias de Rating}

De acordo com cada metodologia analisada, foi possível averiguar que o processo de elaboração do rating de crédito varia conforme cada empresa de classificação de rating, bem como, com a atividade de cada empresa analisada, setor de atuação e localização. As notações da classificação diferem em forma de letras e/ou números, e/ou significado.

A forma de definir essas notas demanda um tratamento estatístico, para identificar quais variáveis deveriam ser utilizadas, bem como para estabelecer os níveis de peso ou pontuação mais adequados para cada empresa analisada. Entretanto, nas três metodologias estudadas, não foi possível identificar quais seriam essas variáveis e qual o modelo estatístico utilizado.

Esses fatores ou itens analisados são obtidos de forma quantitativa e qualitativa.

O quadro, a seguir, foi desenvolvido de acordo com a síntese das informações utilizadas pelas agências de classificação de rating, destacando-se a sobreposição entre os itens analisados: 
Tabela 8 - Classificação de ratings

\begin{tabular}{|c|c|}
\hline Itens Analisados & $\begin{array}{c}\% \\
\text { Sobreposição }\end{array}$ \\
\hline $\begin{array}{c}\text { Fluxo de caixa } \\
\text { liquidez }\end{array}$ & $100 \%$ \\
\hline $\begin{array}{c}\text { Políticas financeiras e da } \\
\text { contabilidade }\end{array}$ & $100 \%$ \\
\hline $\begin{array}{c}\text { Alavancabilidade } \\
\text { proteção de ativos }\end{array}$ & $100 \%$ \\
\hline $\begin{array}{c}\text { Gerenciamento da empresa } \\
\text { Posicionamento de mercado / } \\
\text { posição competitiva }\end{array}$ & $100 \%$ \\
\hline $\begin{array}{c}\text { Ambiente operacional, político } \\
\text { e regulatório }\end{array}$ & $100 \%$ \\
\hline $\begin{array}{c}\text { Características e risco do setor } \\
\text { Garantias da matriz }\end{array}$ & $100 \%$ \\
\hline $\begin{array}{c}\text { Risco de evento especial } \\
\text { Gisance }\end{array}$ & $33 \%$ \\
\hline
\end{tabular}

Fonte: Elaborada pelo Autor

Os principais itens analisados pelas agências de classificação de rating de crédito, conforme destacados na acima, são comuns e utilizados para a definição da classificação do rating de crédito e cada item, receberá um peso definido subjetivamente pelas agências de rating. Potencialmente, os pesos subjetivos atribuídos a cada item analisado podem variar de uma agência de rating e outro especialista de classificação de risco de crédito. Esses pesos não são divulgados pelas agências de rating em função: dos ajustes necessários (pesos atribuídos) para cada tipo (tamanho e setor) de empresa em análise e de uma estratégia confidencial desenvolvida por cada agência de rating, de acordo com as experiências das inúmeras análises realizadas. 
São utilizadas informações qualitativas, bem como quantitativas, na análise global para a elaboração do rating de crédito. A parte qualitativa está relacionada com a averiguação das características do ambiente operacional e tendências do setor. A quantitativa está relacionada ao desempenho econômico-financeiro da empresa analisada.

Nesse trabalho, para testar a hipótese secundária: é possível melhorar o rating de crédito das empresas que utilizam a securitização de recebíveis, utilizou-se: apenas os dados quantitativos, referentes aos itens analisados pelas agências de rating, ou seja, fluxo de caixa, rentabilidade e alavancagem financeira, disponíveis nos balanços patrimoniais, pois os demais itens analisados possuem peso específico e determinado individualmente pelas agências de rating e não divulgado, por questões estratégicas de cada agência. 


\section{CAPÍTULO 4 - METODOLOGIA DA PESQUISA}

"Desde a antiguidade os homens tiveram a preocupação de conhecer os fenômenos da natureza, descobrir os meandros do pensamento de seus semelhantes, encontrar soluções para problemas que deveriam ser explicados e os processos de transmissão dos resultados de suas indagações, utilizando diferentes meios de comunicação".

Saul Goldenberg (Escola Paulista de Medicina)

\section{1 - O Método da Pesquisa}

A pesquisa realiza-se por meio do estudo de um problema que tenha despertado o interesse de investigação do pesquisador.

Conforme Demo (1995, p.11), a pesquisa é o trabalho de coletar dados, sistematizálos e fazer uma descrição da realidade. Nesse sentido, formular o problema de pesquisa consiste em determinar, com precisão, o objetivo central da investigação.

Contudo, a atividade investigativa tem como pressuposto a abordagem científica fundamentada nos princípios da metodologia que, de acordo com Kaplan (1975, p. 25), descreve e analisa os métodos, lançando luz às limitações, realçando a utilidade, esclarecendo em que se baseiam e as conseqüências que acarretam, e indicando suas potencialidades nas nebulosas áreas das fronteiras do conhecimento. Todas as ciências caracterizam-se pela utilização de métodos científicos.

Nesse contexto, acrescenta Ferreira (1992, p. 85): o método científico é definido como um instrumento utilizado pela ciência na sondagem da realidade de um conjunto de proposições explícitas, atitudes e normas, com as quais o investigador ou pesquisador:
a. "coleta dados por meio de observações sistemáticas;
b. avalia os dados obtidos;
c. analisa e infere conclusões; 
d. divulga os resultados, as conclusões e as interpretações;

e. apresenta os resultados de forma a possibilitar a repetição da pesquisa ou do estudo;

f. integra os resultados aos obtidos por diferentes pesquisadores, reformula ou inova os conhecimentos anteriores e realiza novos estudos a partir dos resultados alcançados nas diferentes áreas do conhecimento e

g. generaliza os conhecimentos alcançados, isto é, conclui leis gerais universalmente válidas para todos os casos da mesma espécie."

Nesse sentido, o método é o conjunto de atividades sistemáticas e racionais que, com maior segurança e economia, permite alcançar os objetivos.

Segundo Demo (1995, p.11), a metodologia tem o significado, na origem do termo, do estudo dos caminhos, dos instrumentos para se fazer ciência. Ainda, segundo o autor, "existem quatro tipos delineáveis de pesquisa intercomunicados":

- teórica: formula quadros de referência, estuda teorias, burila conceitos da realidade ou discute abordagens teórico-práticas;

- metodológica: indaga por instrumentos, caminhos, modos de fazer ciência, produz técnicas de tratamento da realidade e discute abordagens teórico-praticas;

- empírica: codifica a face mensurável da realidade social;

- prática: intervém na realidade social, pesquisa participante, avaliação qualitativa, pesquisa-ação.

Para responder às hipóteses apresentadas serão desenvolvidas as pesquisas metodológica e empírica, contemplando as operações de securitização de ativos realizadas pelas empresas, durante o período de 2000 a 2005.

O tipo de metodologia empírica desse projeto, segundo a classificação de Mattar (1996, p. 24), é o de uma pesquisa conclusiva descritiva: a pesquisa descritiva é 
utilizada quando o propósito for descrever características de grupos, estimar a proporção de elementos numa população específica que tenha determinadas características ou comportamentos, e descobrir ou verificar a existência de relação entre as variáveis.

De acordo com Selltiz et al. (1965, p. 60), "a pesquisa exploratória objetiva a formulação de um problema para a investigação ou para a criação de hipóteses". Ainda, segundo esses autores, esse tipo de estudo também apresenta as funções de aumentar o conhecimento sobre uma situação em que se pretende realçar tal estudo, esclarecer conceitos, e estabelecer prioridades para futuras pesquisas. Seguindo essa linha de raciocínio, o ponto de partida para o presente trabalho é a necessidade de se desenvolver modelos, que determinem o impacto que as operações de securitização de recebíveis possam provocar nos indicadores financeiros das empresas.

Específicamente, conforme Lakatos e Mraconi (2001, p.83), a metodologia serve de instrumento para definir o caminho a ser seguido, detectando erros e auxiliando nas decisões do cientista, permitindo a ele a geração de conhecimentos válidos e verdadeiros.

A metodologia empregada para responder às hipóteses e questões apresentadas, será uma variação do arcabouço dos fundamentos dos indicadores financeiros e o beta das empresas, implicando as operações de securitização de recebíveis realizadas pelas empresas brasileiras, durante o período citado.

O problema estudado apresenta fundamentação teórica, além de evidências empíricas que sustentam as hipóteses de pesquisa formuladas.

Para atender aos objetivos do método de pesquisa foi utilizada uma amostra que representou quase a totalidade da população de empresas que já realizaram operações de securitização de recebíveis no mercado brasileiro, no período de 2000 a 2005. 


\section{2 - Hipóteses Formuladas}

Conforme Demo (1995, p.163), "um experimento é o teste de uma hipótese, que tenta relacionar mutuamente dois fatores em uma relação causal, por pesquisa em situações diversas". As hipóteses são suposições aceitáveis, no sentido de poderem ser argumentadas.

De acordo com Sousa et al. (1976, p. 80), o método hipotético-dedutivo compreende as seguintes etapas:

1. Formulação das hipóteses, a partir de um fato-problema;

2. Inferência das conseqüências preditivas das hipóteses e

3. Teste das conseqüências preditivas, por meio da experimentação, a fim de confirmar ou recusar as hipóteses.

Segundo Leme (Apud Securato, 1996, p. 17), “a previsão é o processo pelo qual a partir de informações existentes, admitidas certas hipóteses e por meio de algum método de geração, chegamos a informações sobre o futuro, com uma determinada finalidade".

O principal objetivo do presente trabalho é o de apresentar evidências empíricas do impacto que a securitização pode causar nos indicadores financeiros e no beta das empresas que utilizam essa forma estruturada de captação de recursos.

Para atingir os objetivos da pesquisa e orientar o procedimento de análise e tratamento dos dados, serão formuladas algumas hipóteses, apresentadas na fórmula nula:

$H_{O, 1}$ : existem relações entre a alavancagem (financeira, operacional e total) e o beta;

$H_{O, 2}$ : existe relação entre a alavancagem (financeira, operacional e total) e o beta alavancado;

$H_{O, 3}$ : existem relações entre a alavancagem (financeira, operacional e total) e as lucratividades (economica e financeira); 
$H_{O, 4}$ : existe impacto da securitização de ativos nas três hipóteses anteriores.

O objetivo secundário é o de examinar o comportamento do rating de crédito das empresas corporativas que realizaram operações de securitização.

Essa hipótese é secundária devido ao pequeno número de dados disponíveis para a realização de um teste efetivo da relação entre a securitização de recebíveis e o rating de crédito das empresas corporativas.

$H_{O, 5}$ : é possível melhorar o rating de crédito das empresas que utilizam a securitização de ativos.

Com o propósito de responder a essas questões, as hipóteses apresentadas foram testadas utilizando-se diferentes medidas e períodos de análise, como demonstrado no quadro a seguir, adaptado do modelo sugerido por Oda (2004, p. 76):

\section{Quadro 11 - Hipóteses e indicadores das variáveis utilizadas na pesquisa}

\begin{tabular}{|c|c|c|c|}
\hline Hipótese & Variáveis & Indicadores & $\begin{array}{l}\text { Períodos de } \\
\text { análise }\end{array}$ \\
\hline Hipótese 1 & $\begin{array}{c}\text { Beta } \\
\text { Graus de alavancagem }\end{array}$ & $\begin{array}{c}\text { Beta de mercado das ações } \\
\text { Grau de alavancagem operacional } \\
\text { Grau de alavancagem financeira } \\
\text { Grau de alavancagem total }\end{array}$ & 6 anos \\
\hline Hipótese 2 & $\begin{array}{c}\text { Beta alavancado } \\
\text { Graus de alavancagem }\end{array}$ & $\begin{array}{c}\text { Beta alavancado das empresas } \\
\text { Grau de alavancagem operacional } \\
\text { Grau de alavancagem financeira } \\
\text { Grau de alavancagem total }\end{array}$ & 6 anos \\
\hline Hipótese 3 & Índices de lucratividade & $\begin{array}{l}\text { Índice de lucratividade financeira } \\
\text { Índice de lucratividade econômica } \\
\text { Grau de alavancagem operacional } \\
\text { Grau de alavancagem financeira } \\
\text { Grau de alavancagem total }\end{array}$ & 6 anos \\
\hline
\end{tabular}




\begin{tabular}{|c|c|c|c|}
\hline Hipótese 4 & $\begin{array}{c}\text { Beta } \\
\text { Beta alavancado } \\
\text { Graus de alavancagem } \\
\text { Índices de lucratividade }\end{array}$ & $\begin{array}{l}\text { Mesmos indicadores das } \\
\text { hipóteses } 1,2 \text { e } 3 \text { após o início da } \\
\text { securititização }\end{array}$ & 3 anos \\
\hline Hipótese 5 & $\begin{array}{l}\text { Indicadores financeiros de } \\
\text { rating de crédito }\end{array}$ & $\begin{array}{c}\text { Índice de liquidez corrente } \\
\text { Índice de liquidez imediata } \\
\text { Índice de liquidez seca } \\
\text { Índice de liquidez geral } \\
\text { Índice de lucratividade financeira } \\
\text { Índice de alavancagem } \\
\text { Índice de endividamento total } \\
\text { Índice de cobertura dos juros } \\
\text { Retorno sobre ativos totais } \\
\text { Retorno sobre o patrimônio líquido }\end{array}$ & 6 anos \\
\hline
\end{tabular}

Fonte: Elaborado pelo Autor

\section{3 - População e Amostra}

A população a ser pesquisada será composta pelas empresas que realizaram operações de securitização ou fundos de recebíveis, no mercado doméstico brasileiro, bem como no mercado externo, realizadas no período compreendido entre 2000 e 2005. As empresas selecionadas, conforme a relação do quadro 12 a seguir, foram aquelas que possuíam ações negociadas na BOVESPA, totalizando 18 empresas pesquisadas. 
Quadro 12 - Relação de Empresas Selecionadas

\begin{tabular}{|l|l|}
\hline Nome da Empresa & Nome completo da empresa \\
\hline Acesita & Acesita S.A. \\
\hline Aracruz & Aracruz Celulose SA \\
\hline Braskem & Braskem S.A. \\
\hline Cataguazes & Cataguazes Leopoldina \\
\hline Cesp & Cesp - Cia. Energetica de Sao Paulo \\
\hline CBD & Cia Brasileira de Distribuição \\
\hline Copesul & Copesul - Cia. Petroquimica do Sul \\
\hline CPFL Piratininga & Cia. Piratininga de Forca e Luz \\
\hline Gradiente & Gradiente Eletronica s a \\
\hline Perdigao & Perdigao S.A. \\
\hline Petroflex & Petroflex Industria e Comercio S.A. \\
\hline Sadia & Sadia S.A. \\
\hline Sansuy & Sansuy S.A Insdútria de Plásticos \\
\hline CST & Cia Sid Tubarao \\
\hline Telesp & Telec. de Sao Paulo S/A-Telesp \\
\hline Triken & Triken S/A \\
\hline Telefônica & Telefônica SA \\
\hline Vale Rio Doce & Cia Vale do Rio Doce \\
\hline
\end{tabular}

\section{Fonte: Elaborado pelo Autor}

Essas empresas selecionadas configuram-se como cedentes dos recebíveis, ou seja, os recebíveis que faziam parte do contas a receber, tanto de recebíveis locais quanto de recebíveis de exportações.

A escolha desse período foi estabelecida em função das principais empresas utilizarem esse tipo de operação, somente a partir de 2000, bem como do surgimento dos Fundos de Investimentos de Direitos Creditórios - FIDC, a partir de 2001, por meio da autorização do Banco Central do Brasil - BACEN e da Comissão de Valores Mobiliários - CVM.

Para atender aos objetivos do método de pesquisa, foi utilizada amostra composta pelos balanços patrimoniais disponíveis e referentes às empresas que já realizaram operações de securitização de ativos no mercado brasileiro e externo no período em análise, e que possuem ações negociadas em bolsa. Somente foram selecionadas as empresas que possuem capital aberto e serão calculados alguns indicadores financeiros e respectivas correlações, a fim de responder às hipóteses.

Os recebíveis são originados pelas vendas a prazo de bens ou serviços das empresas e esses recebíveis serão utilizados como lastro dos títulos a serem 
emitidos pela sociedade de propósito específico - SPE. Os recebíveis podem ser de vendas locais (mercado brasileiro) ou vendas de exportação.

\section{4 - Coleta de Dados}

Os dados utilizados na pesquisa são secundários e foram obtidos por meio do sistema Economática, disponível no Laboratório de Finanças - Labfin da Fundação Instituto de Administração - FIA. Foram também obtidos dados de rating de crédito por meio das empresas de classificação de rating de crédito que atuam no Brasil, ou seja, Moody's Investors Service, Fitch IBCA Investors Service e Standard \& Poor's.

\section{5 - Indicadores Financeiros}

\subsection{1 - Grupos de Índices Financeiros}

A análise por meio de índices financeiros pode ser usada para comparar o desempenho e a situação de uma empresa em relação aos índices de outras empresas, bem como para analisar sua performance em um determinado período de tempo. Os dados foram obtidos a partir dos balanços patrimoniais publicados.

Índice de liquidez Corrente $\left(\mathrm{I}_{\mathrm{LC}}\right)$ :

- Mensura a capacidade da empresa pagar suas obrigações a curto prazo com suas disponibilidades financeiras, contas a receber e estoques.

O índice de liquidez corrente é apurado pela fórmula:

$$
\mathrm{I}_{\mathrm{LC}}=\frac{\text { Ativo Circulante }}{\text { Passivo Circulante }}
$$


Índice de Liquidez Imediata $\left(\mathrm{I}_{\mathrm{LI}}\right)$ :

- Mensura a capacidade da empresa de pagar suas obrigações a curto prazo com suas disponibilidades financeiras (caixa + aplicações financeiras).

- O índice de liquidez imediata pode ser apurado pela fórmula:

$$
I_{L I}=\frac{\text { Disponibilidades }}{\text { Passivo Circulante }}
$$

Índice de liquidez seca ( $\left.\mathrm{I}_{\mathrm{LS}}\right)$ :

- Mensura a capacidade da empresa pagar suas obrigações a curto prazo com suas disponibilidades financeiras e contas a receber. Esse índice exclui o estoque, que é geralmente o Ativo Circulante menos Líquido.

- O índice de liquidez seca pode ser apurado pela fórmula:

$$
\mathrm{I}_{\mathrm{LS}}=\frac{\text { Ativo Circulante-Estoque }}{\text { Passivo Circulante }}
$$

Índice de Liquidez Geral $\left(\mathrm{I}_{\mathrm{LG}}\right)$ :

- Mensura a capacidade da empresa de pagar suas obrigações totais com seus ativos de curto e longo prazos.

- O índice de liquidez geral pode ser apurado pela fórmula:

$$
I_{L G}=\frac{\text { Ativo Circulante+Ativo Realizável a Longo Prazo }}{\text { Passivo Circulante+Passivo Exigível a Longo Prazo }}
$$




\subsection{2 - Análise do Endividamento}

A situação de endividamento de uma empresa indica o montante de recursos de terceiros (recursos onerosos) que está sendo utilizado na tentativa de gerar resultados positivos. Nesse sentido, o administrador financeiro deverá possuir uma estratégia de endividamento, visando à alavancagem financeira e, conseqüentemente, proporcionará um retorno maior.

Índice de Endividamento Total $\left(\mathrm{I}_{\mathrm{ET}}\right)$ :

- Demonstra a participação percentual de recursos de terceiros no financiamento do ativo ou investimento total.

- Quanto maior esse índice, maior será a alavancagem financeira da empresa.

- O índice de endividamento total pode ser apurado pela fórmula:

$$
\mathrm{I}_{\mathrm{ET}}=\frac{\text { Passivo Circulante Oneroso }+ \text { Exígivel de Longo Prazo Oneroso }}{\text { Ativo Total }}
$$

Índice de Endividamento Bancário no Curto Prazo ( $\left.\mathrm{I}_{\mathrm{EBCP}}\right)$

- Demonstra quanto os empréstimos bancários de curto prazo representam percentualmente do total das dívidas de curto prazo.

- O índice de endividamento bancário, no curto prazo, pode ser apurado pela fórmula:

$$
\mathrm{I}_{\mathrm{EBCP}}=\frac{\text { Empréstimos Bancários de Curto Prazo }}{\text { Passivo Circulante }}
$$


Índice de Alavancagem $\left(\mathrm{I}_{\mathrm{A}}\right)$ :

- Demonstra a proporção entre dívidas e capital dos proprietários no financiamento dos ativos.

- O índice de alavancagem pode ser apurado pela fórmula:

$$
\mathrm{I}_{\mathrm{A}}=\frac{\text { Passivo Circulante Oneroso+Exígivel de Longo Prazo Oneroso }}{\text { Patrimônio Líquido }}
$$

\section{6 - Alavancagem Financeira}

$\mathrm{Na}$ área financeira, o termo alavancagem é aplicado como uma analogia às propriedades das alavancas estudadas pela física clássica. Nesse sentido, a alavancagem financeira é o efeito de tomar recursos de terceiros a determinado custo (taxa de juros) e, aplicando-os em ativos operacionais a uma determinada taxa de retorno: como conseqüência, a diferença entre essas duas taxas será a remuneração dos proprietários (acionistas) e pode alterar o retorno sobre o patrimônio líquido, para mais ou para menos do que aquele que seria obtido, caso todo o investimento fosse feito apenas com recursos próprios.

Figura 10 - Alavancagem Financeira

Não

Alavancada Alavancada

\begin{tabular}{|c|c|c|}
\hline EBIT esperado (inalterado) & 45.000 & 45.000 \\
\hline Juros ( $20 \%$ sobre $\$ 90.000$ de dívida) & 0 & 18.000 \\
\hline LAIR & 45.000 & 27.000 \\
\hline Impostos (35\%) & 15.750 & 9.450 \\
\hline Lucro Líquido & 29.250 & 17.550 \\
\hline
\end{tabular}

Fonte: Adaptada de Brighan e Weston (2001, p. 571)

A alavancagem financeira reflete a determinação do resultado e, consequentemente, aumenta o risco dos investidores, porém, de forma positiva, o uso de capital de terceiros é importante, pois oferece vantagem fiscal significativa, por meio da 
redução da base tributária, devido ao reconhecimento do custo da dívida, conforme demonstrado na figura 10.

Ross, et al. (2002, p. 48) enfatizam :

"A alavancagem financeira está associada à intensidade com a qual a empresa utiliza recursos de terceiros (...) quanto mais endividada estiver uma empresa, mais provável é que se torne incapaz de cumprir suas obrigações contratuais. Em outras palavras, muita dívida pode levar a uma probabilidade maior de insolvência e dificuldades financeiras".

Note-se que a alavancagem financeira, também conhecida na literatura financeira como sendo grau de alavancagem financeira, depende da relação: capital de terceiros / capital próprio e do diferencial de taxas que por sua vez, é dada por:

$$
\mathrm{GAF}=\frac{\mathrm{ROA}+(\mathrm{ROA}-\mathrm{Ki}) \times \frac{\mathrm{P}}{\mathrm{PL}}}{\mathrm{ROA}}
$$

em que:

GAF = Grau de alavancagem financeira;

ROA = Retorno sobre ativos;

$\mathrm{k}_{\mathrm{I}}=$ Custo de capital de terceiros;

$\mathrm{P}=$ Passivo oneroso e

PL = Patrimônio líquido .

Como roposição a, quanto mais recursos de terceiros uma empresa tenha em relação ao capital próprio, maior rentabilidade terá proporcionalmente a seus próprios recursos investidos, porém, dependerá da variável taxa de juros (custo do capital de terceiros) vis-à-vis a taxa de retorno dos ativos. Quanto menor a participação de capital próprio, maior a dificuldade de obter empréstimos e maior tenderá a própria taxa de captação de recursos, em razão do maior risco financeiro assumido pela empresa. 
De acordo com Brigham e Houston (1999, p. 469), o grau de alavancagem financeira (GAF) é também definido como a variação percentual no lucro por ação (LPA) que resulta de uma dada variação percentual no lucro antes dos juros e impostos (LAJIR) e é dada como:

$\mathrm{GAF}=\frac{\text { variação percentual no LPA }}{\text { variação percentual no LAJIR }}$

Deduzindo a equação (4.2) tem-se:

$\mathrm{LPA}=\frac{[(\text { LAJIR-J })(1-\mathrm{T})]}{\mathrm{N}}$

sendo:

$\mathrm{J}$ : os juros pagos ou custo de capital de terceiros

T: a alíquota do imposto de renda

N: o número de ações em circulação

O LAJIR é dado como:

$\mathrm{LAJIR}=\mathrm{Q}(\mathrm{P}-\mathrm{V})-\mathrm{F}$

sendo:

$Q$ : quantidade de unidades vendidas

$\mathrm{P}$ : o preço por unidade

V: o custo variável por unidade

$\mathrm{F}$ : os custos fixos totais

Logo, a variação no LPA é dado como:

$\Delta \mathrm{LPA}=\frac{(\Delta \mathrm{LAJIR}-\Delta \mathrm{J})(1-\mathrm{T})}{\mathrm{N}}$ 
Considerando-se que $\mathrm{J}$ é uma constante, $\log \mathrm{J}=0$ :

$\Delta \mathrm{LPA}=\frac{\Delta \mathrm{LAJIR}(1-\mathrm{T})}{\mathrm{N}}$

Por definição, a variação percentual no LPA é a variação no LPA dividida pelo LPA original; portanto, tem-se:

$\Delta \mathrm{LPA}=\frac{\frac{\Delta \mathrm{LAJIR}(1-\mathrm{T})}{\mathrm{N}}}{\frac{(\mathrm{LAJIR}-\mathrm{J})(1-\mathrm{T})}{\mathrm{N}}}=\left[\frac{\Delta \operatorname{LAJIR}(1-\mathrm{T})}{\mathrm{N}}\right]\left[\frac{\mathrm{N}}{(\text { LAJIR-J })(1-\mathrm{T})}\right] \Leftrightarrow$

$\Delta \mathrm{LPA}=\frac{\Delta \mathrm{LAJIR}}{\text { LAJIR-J }}$

Substituindo (4.6) em (4.2), tem-se:

$\mathrm{GAF}=\frac{\frac{\Delta \text { LAJIR }}{\text { LAJIR-J }}}{\frac{\text { ALAJIR }}{\text { LAJIR }}}=\left(\frac{\Delta \text { LAJIR }}{\text { LAJIR-J }}\right)\left(\frac{\text { LAJIR }}{\Delta \text { LAJIR }}\right)$

Logo, o Grau de Alavancagem Financeira é dado como:

$\mathrm{GAF}=\frac{\text { LAJIR }}{\text { LAJIR-J }}$

\section{7 - Alavancagem Operacional}

O grau de alavancagem operacional é uma função da estrutura de custo da empresa e é normalmente definido, segundo Damodaran (2004, p.103), em termos da relação entre custos fixos e custos totais.

Por definição, a expressão do grau de alavancagem operacional (GAO) pode ser definido como a variação percentual no lucro operacional (ou LAJIR), que resulta de uma dada variação percentual nas vendas: 
GAO $=\frac{\text { Variação no lucro operacional }}{\text { Variação no volume de atividade }}$ ou $\mathrm{GAO}=\frac{\text { Variação_\%_do_LAJIR }}{\text { Variação_\%_nas_Vendas }}$

Podendo ser reescrita como:

$\mathrm{GAO}=\frac{\frac{\Delta \text { LAJIR }}{\text { LAJIR }}}{\frac{\Delta \mathrm{Q}}{\mathrm{Q}}}$

Conforme Brigham e Houston (1999, p. 467), o GAO é variação percentual no LAJIR, resultante de uma dada variação percentual nas vendas, ou seja, é um número índice que mede o efeito de uma variação nas vendas sobre o lucro operacional, ou LAJIR.

Em forma de equação tem-se o LAJIR como: LAJIR=Q(P-V)-F

sendo:

Q: quantidade de unidades vendidas

P: o preço por unidade

V: o custo variável por unidade

F: os custos fixos totais

Considerando-se que a variação do LAJIR é:

$\Delta \mathrm{LAJIR}=\Delta \mathrm{Q}(\mathrm{P}-\mathrm{V})-\mathrm{F}$

De modo que a varição percentual do LAJIR é:

$\% \Delta \mathrm{LAJIR}=\frac{\Delta \mathrm{Q}(\mathrm{P}-\mathrm{V})}{\mathrm{Q}(\mathrm{P}-\mathrm{V})-\mathrm{F}}$ 
Substituindo (4.11) em (4.9), tem-se:

$\mathrm{GAO}=\frac{\frac{\Delta \mathrm{Q}(\mathrm{P}-\mathrm{V})}{\mathrm{Q}(\mathrm{P}-\mathrm{V})-\mathrm{F}}}{\frac{\Delta \mathrm{Q}}{\mathrm{Q}}}=\left(\frac{\Delta \mathrm{Q}(\mathrm{P}-\mathrm{V})}{\mathrm{Q}(\mathrm{P}-\mathrm{V})-\mathrm{F}}\right)\left(\frac{\mathrm{Q}}{\Delta \mathrm{Q}}\right)$

Logo, o Grau de Alavancagem Operacional é dado como:

$\mathrm{GAO}=\frac{\mathrm{Q}(\mathrm{P}-\mathrm{V})}{\mathrm{Q}(\mathrm{P}-\mathrm{V})-\mathrm{F}}$

O grau de alavancagem operacional é determinado pela estrutura de custos (despesas) da empresa, apresentando maior capacidade de alavancar os lucros, ou seja, aquela empresa que apresentar maiores custos (despesas) fixos em relação aos custos (despesas) totais. Logo, empresas com estrutura mais elevada de custos (despesas) fixos assumem também maiores riscos, em razão da maior variabilidade de seus resultados operacionais.

Conforme Weston e Brigham (2.000, p. 353), a equação do GAO (4.8) pode ser reescrita como sendo:

$\mathrm{GAO}=\frac{\text { Receita }- \text { Custos Variáveis }}{\text { Receita }- \text { Custos Variáveis }- \text { Custos Fixos }}$

De acordo com Oda (2004, p. 84) a utilização dessa equação do GAO, requer a identificação dos custos fixos e variáveis das empresas, porém esses custos não são apresentados nas demonstrações financeiras de publicação obrigatória. Foi utilizada, nesse trabalho, a equação do GAO, apresentada em (4.9), que requer apenas a observação das variações de lucros e receitas de um trimestre para o seguinte.

\section{8 - Alavancagem Total}

A alavancagem total também conhecida na literatura financeira como Grau de Alavancagem Total ou GAT demonstra os efeitos combinados da alavancagem 
operacional e da alavancagem financeira. O GAT mostra como uma dada variação nas vendas afetará o lucro por ação (LPA).

Por definição, a equação do GAT postula que:

$\mathrm{GAT}=(\mathrm{GAO})(\mathrm{GAF})$

Deduzindo-se a partir das equações GAO (4.12) e GAF (4.7), tem-se:

$\mathrm{GAT}=\left[\frac{\mathrm{Q}(\mathrm{P}-\mathrm{V})}{\mathrm{Q}(\mathrm{P}-\mathrm{V})-\mathrm{F}}\right]\left[\frac{\mathrm{Q}(\mathrm{P}-\mathrm{V})-\mathrm{F}}{\mathrm{Q}(\mathrm{P}-\mathrm{V})-\mathrm{V}-\mathrm{J}}\right] \Leftrightarrow$

Logo, o Grau de Alavancagem Total é dado como:

$\mathrm{GAT}=\frac{\mathrm{Q}(\mathrm{P}-\mathrm{V})}{\mathrm{Q}(\mathrm{P}-\mathrm{V})-\mathrm{F}-\mathrm{J}}$

Conforme Brighan e Houstom (1999, p. 471), o conceito de grau de alavancagem também é útil para os investidores, por exemplo, caso as empresas de um determinado setor sejam ordenadas de acordo com o grau de alavancagem total, um investidor mais otimista acerca das perspectivas de tal setor poderia preferir as empresas com alta alavancagem. Ocorreria o inverso, caso se espere uma queda nas vendas.

Paradoxalmente, a rentabilidade esperada de uma carteira é igual à média ponderada das rentabilidades esperadas dos títulos e valores mobiliários que a compõem, conforme destaca Brealey e Myers (2003, p. 107). A rentabilidade esperada de uma carteira formada por todos os títulos e valores mobiliários da empresa pode ser descrita a partir da equação do Custo Médio Ponderado de Capital - CPMC que, por definição, é dado por:

$\mathrm{CMPC}=\left(\frac{\mathrm{D}}{\mathrm{D}+\mathrm{E}}\right) \mathrm{K}_{\mathrm{d}}+\left(\frac{\mathrm{E}}{\mathrm{D}+\mathrm{E}}\right) \mathrm{K}_{\mathrm{e}}$

sendo:

Ke = custo do capital próprio; 
$\mathrm{Kd}=$ custo do capital de terceiros

$\mathrm{D}$ = valor de mercado da dívida

$\mathrm{E}=$ valor de mercado do capital próprio

Logo, a partir da equação do CMPC, a rentabilidade esperada de uma carteira formada por todos os títulos e valores mobiliários da empresa pode ser descrita como:

$r_{A}=\left(\frac{D}{D+E}\right) r_{D}+\left(\frac{E}{D+E}\right) r_{E}$

Assumindo essa equação, pode-se refazê-la para obter-se o retorno esperado do capital próprio de uma empresa alavancada:

$r_{E}=r_{A}+\frac{D}{E}\left(r_{A}-r_{D}\right)$

sendo:

$\mathrm{r}_{\mathrm{E}}=$ retorno esperado sobre o patrimônio;

$\mathrm{r}_{\mathrm{A}}=$ retorno esperado sobre os ativos;

$\frac{\mathrm{D}}{\mathrm{E}}=$ índice de dívida sobre o patrimônio;

$r_{D}=$ retorno esperado sobre a dívida.

De acordo com Brealey e Myers (1998, p. 455), a taxa esperada de remuneração das ações de uma empresa com dívida (capital de terceiros), aumenta proporcionalmente ao índice de endividamento $\left(\frac{\mathrm{D}}{\mathrm{E}}\right)$, em que $\mathrm{D}$ é o valor da dívida e E o valor do capital próprio. Logo, a taxa de aumento depende do spread entre $r_{A}$, a taxa de retorno esperada sobre uma carteira de todos os títulos da empresa, e $r_{D}$, o retorno esperado sobre a dívida. Caso a empresa não tenha dívida: $\mathrm{r}_{\mathrm{E}}=\mathrm{r}_{\mathrm{A}}$. 
Modigliani e Miller (1965, p.135) argumentam que o valor do crescimento capitalizado depende da rentabilidade das oportunidades futuras, de seu montante e do período de tempo durante o qual irão perdurar.

Dessa feita, as obrigações da empresa são essencialmente livres de risco em níveis de endividamento baixos. Assim, $r_{D}$ é independente de $\frac{D}{E}$ e $r_{E}$ aumenta linearmente à medida que $\frac{\mathrm{D}}{\mathrm{E}}$ aumenta. Conforme a empresa realiza mais empréstimos, o risco de crédito aumenta e a empresa é forçada a pagar taxas de juros sobre os empréstimos maiores.

Via de regra, de acordo com rop et al. (2001, p.73), o capital de terceiros é mais barato do que o capital próprio, uma vez que o primeiro implica uma obrigação contratual de pagamentos por parte da empresa enquanto o último constitui um direito residual sobre o fluxo de caixa.

Uma influente escola de pensamento que argumenta que decisões sobre estrutura de capital não afetam realmente o valor da empresa. As hipóteses deste argumento foram lançadas no artigo inicial de (MODIGLIANI e MILLER, 1958), conhecida como roposição I, em que a base do teorema desses autores foi que o ambiente das empresas era livre de impostos, de custos de transação e de possibilidade de inadimplência. Neste ambiente, os autores concluíram que o valor de uma empresa nãi era afetado por sua alavacagem financeira e que decisões sobre investimentos e financiamentos poderiam ser segregadas.

Em um estudo posterior, (MODIGLIANI e MILLER, 1963), mantiveram o ambiente utilizado anteriormente porém fizeram uma modificação, permitindo benefícios do imposto de renda para a dívida.

Em Modigliani e Miller (1958, p.268), é previsto que quanto mais dívida a empresa tiver, menos sensível é o $\mathrm{r}_{\mathrm{E}}$ para novos empréstimos. Isso ocorre, porque os portadores de dívidas assumem os riscos do negócio da empresa e, conforme a empresa efetua mais empréstimos, mais desse risco é transferido dos acionistas 
para os credores. Tal afirmação pode ser observada no Quadro 13 a seguir, que demonstra a diminuição da inclinação da linha $r_{E}$, à medida que $0 \frac{D}{E}$ aumenta.

\section{Quadro 13 - Relação entre a Estrutura de Capital e o CMPC no Ambiente de Modgliani e Miller}

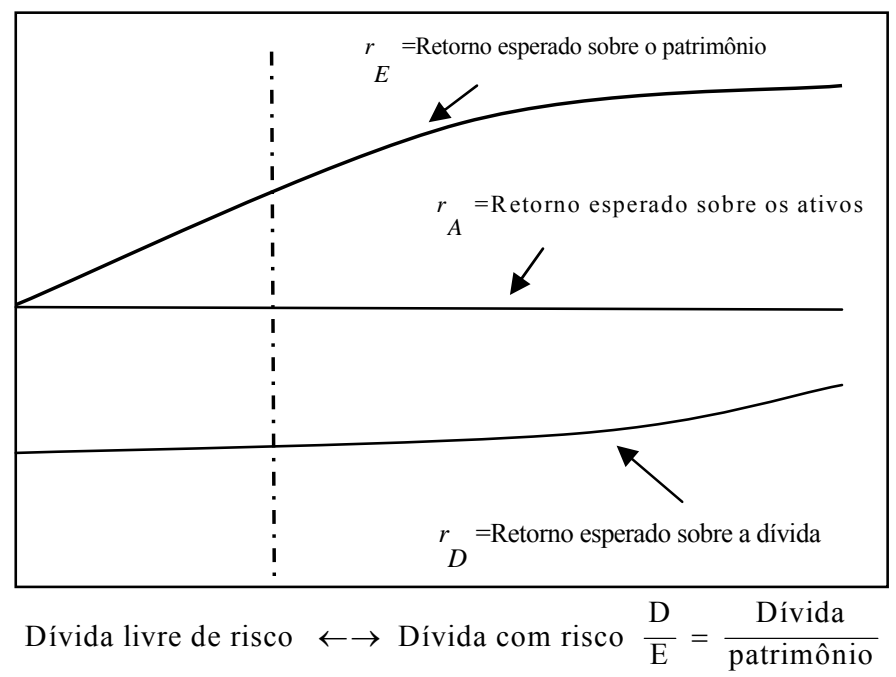

Fonte: Adaptado de Brealey e Myers (1998, p. 456)

Esse quadro demonstra a proposição II de Modigliani e Miller (1958, p.268), ou seja, o retorno esperado sobre o patrimônio $r_{E}$ aumenta linearmente com o índice dívida/patrimônio $\left(\frac{\mathrm{D}}{\mathrm{E}}\right)$ enquanto a dívida estiver livre de risco. Mas se a alavancagem aumentar o risco da dívida, os credores exigem um retorno mais alto sobre a dívida. Isso faz com que a taxa de aumento em $r_{E}$ desacelere.

Paradoxalmente, de acordo com a teoria tradicional, modificações no uso de capitais de terceiros ocasionarão modificações nos lucros por ação (LPA) e conseqüentemente no lucro por ação. Nesse sentido, de acordo com Damodaran (2002, p. 28), os pontos mais forte e o mais fraco das finanças corporativas é o seu foco centrado sobre a maximização do valor da empresa. O efeito de maximizar o valor da empresa dependerá de três decisões:

1. A decisão sobre o investimento: investir em projetos que ofereçam um retorno maior do que a taxa mínima de atratividade; 
2. A decisão sobre financiamento: selecionar um conjunto de financiamentos (inclui dívida e capital próprio) que maximize os valores dos projetos selecionados e que exista um casamento entre os prazos dos financiamentos e os ativos financiados e

3. A decisão sobre dividendos: se não há investimentos suficientes que superem a taxa mínima de atratividade, então se devolve a totalidade dos lucros aos acionistas.

\section{Gráfico 7 - Relação entre a Estrutura de Capital e o CMPC no Ambiente Tradicional}

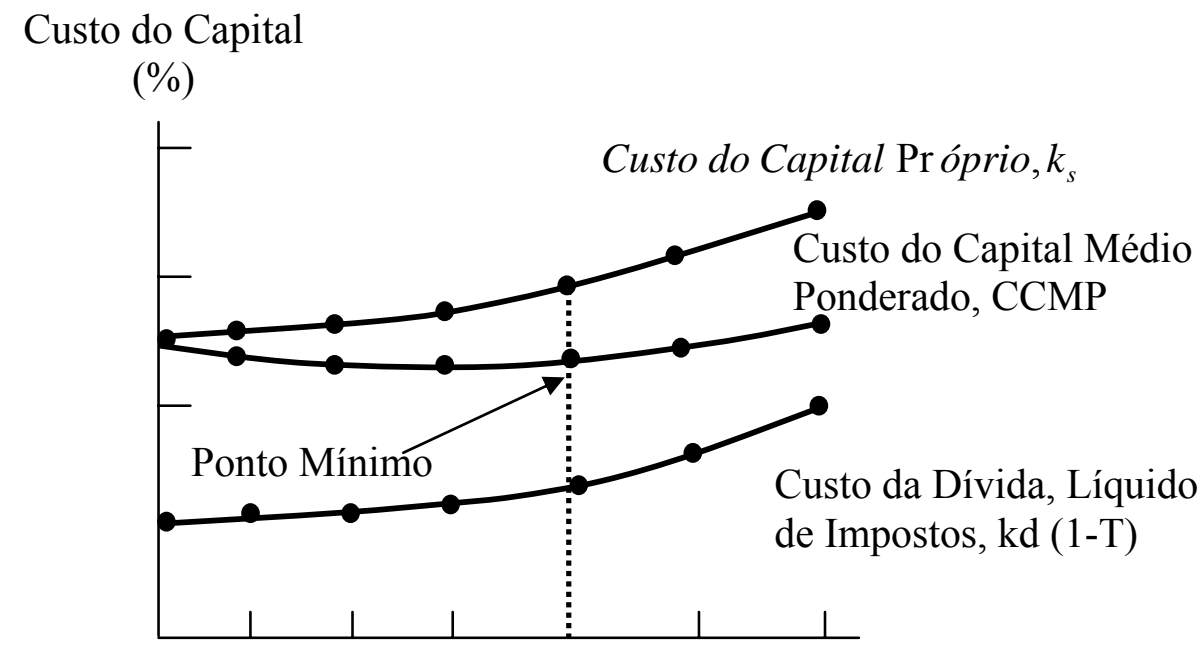

Capital de Terceiros/Ativos (\%)

Fonte: Adaptado de Brigham e Houston (1999, p. 466)

Nesse gráfico, demonstra-se que no ponto mínimo indicado, o preço esperado da ação é maximizado (Ks) e, o custo do capital médio ponderado é minimizado (CMPC). Portanto, esse ponto mínimo estabelece a estrutura ótima de capital que a empresa deverá seguir, visando-se maximização da relação entre a estrutura de capital, seu LPA, custo de capital e consequentemente, o preço das ações.

Segundo Famá et al. (2001, p.73), o trabalho inicial (Proposição I) de (MODIGLIANI e MILLER, 1958) baseia-se na formulação de demonstração de duas proposições 
acerca do relacionamento entre a estrutura de capital e o valor da empresa, bem como entre a estrutura de capital e as decisões de investimento da empresa. Sua proposição I foi, assim, formulada (MODIGLIANI e MILLER 1958, p. 268):

"...the market value of any firm is independent of its capital structure and is given by capitalizing its expected return at the rate $p_{k}$ appropriate to its class".

Em outros termos, a Proposição I afirma que a proporção de capital de terceiros em relação ao capital próprio utilizado por uma empresa é completamente irrelevante para a determinação de seu valor de mercado. Tal afirmação é demonstrada conforme a equação abaixo:

$$
i_{s}=\rho+\left(\rho-i_{d}\right) \frac{D}{S}
$$

\section{Gráfico 8 - CMPC e Custo do Capital próprio na ausência de impostos}

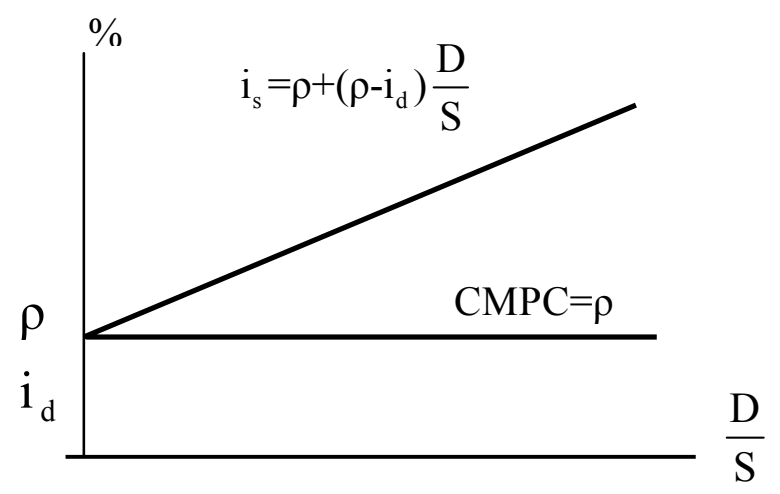

Fonte: Copeland et al. (1988, p. 250)

Posteriormente, entretanto Modigliani e Miller (1963, p. 53) corrigem seu raciocínio, apontando para um erro no trabalho original e propondo uma nova alíquota de imposto corporativo maior do que zero. Nesse artigo de 1963, Modigliani e Miller demonstram como o custo do capital próprio se relaciona com a alavancagem financeira na presença de uma alíquota de imposto de renda corporativo maior do que zero. Tal afirmação pode ser demonstrada de acordo com a equação abaixo:

$$
i_{s}=\rho+\left(1-\tau_{c}\right)\left(\rho-i_{d}\right) \frac{D}{S}
$$


Gráfico 9 - CMPC e Custo do capital próprio quando $\tau_{c}>0$

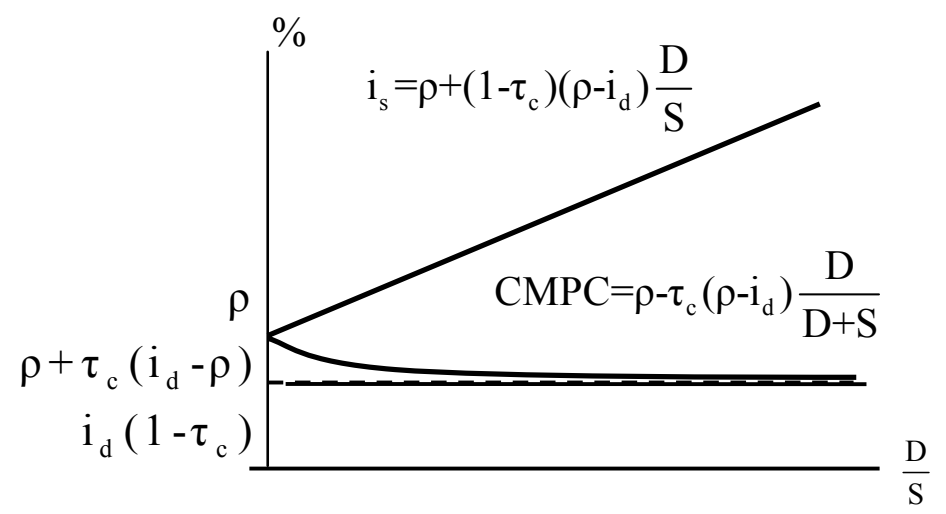

Fonte: Copeland e Weston (1988, p. 250)

Nesse gráfico vê-se que o CMPC cairá sempre com o aumento da alavancagem, até o limite de $\rho+\tau_{c}\left(i_{d}-\rho\right)$ quando $D \rightarrow \infty$.

De acordo com Famá et al. (2001, p. 72), uma teoria de equilíbrio de mercado que permitia calcular o custo do capital próprio surgiu somente com a publicação do trabalho de Sharpe (1964) e Lintner (1965) e seu Capital Asset Princing Model CAPM. Embora também envolto em controvérsias, o CAPM permanece como modelo mais utilizado no mercado de capitais para o cálculo do retorno exigido pelos acionistas de uma empresa, de maneira a compensá-los pelo risco de seu investimento.

\section{9 - Beta de Mercado}

O beta de mercado das ações das empresas analisadas, ou beta corrente, pode ser calculado a partir dos betas diários ou trimestrais. A escolha, nesta pesquisa, foi pelos betas de mercado trimestrais, e deu-se em função das observações de Oda (2004, p.106) que destaca dois fatores principais, para a utilização dos betas trimestrais:

1. "permitem maior flexibilidade na utilização dos resultados da pesquisa, possibilitando que sejam aplicados a ações de menor liquidez, para as quais eventualmente não seja possível obter uma série completa de dados diários e 
2. são apurados em prazo compatível com a menor periodicidade obrigatória de publicação de demonstrativos financeiros das empresas de capital aberto negociadas na Bovespa".

O beta corrente para uma empresa pode ser estimado a partir de uma regressão, mas ele é determinado por decisões fundamentais que a empresa tenha tomado. Essas decisões podem ser tanto operacionais quanto de investimentos, logo terão impacto na alavancagem operacional ou alavancagem financeira, respectivamente.

O procedimento-padrão definido por Damodaran (2004, p. 93) para se estimar betas é fazer a regressão dos retornos de ações $\left(R_{a}\right)$ sobre os retornos de mercado $\left(R_{m}\right)$

$\mathrm{R}_{\mathrm{a}}=\mathrm{a}+\mathrm{b} \mathrm{R}_{\mathrm{m}}$ (equação da regressão)

em que:

$a=$ intersecção da regressão

$\mathrm{b}=$ inclinação da regressão = Covariância $\left(\mathrm{R}_{\mathrm{j}}, \mathrm{R}_{\mathrm{m}}\right) /$

A inclinação da regressão corresponde ao beta da ação e mensura o risco do ativo. Já a intersecção da regressão fornece uma medida simples do desempenho durante o período da regressão, em relação ao modelo de precificação de ativos de capital (CAPM - Capital Asset Pricing Model), conforme a equação a seguir:

$\mathrm{R}_{\mathrm{j}}=\mathrm{R}_{\mathrm{f}}+\beta\left(\mathrm{R}_{\mathrm{m}}-\mathrm{R}_{\mathrm{f}}\right)$

Logo:

$\mathrm{R}_{\mathrm{f}}(1-\beta)+\beta \mathrm{R}_{\mathrm{m}}$

Pelo exposto, uma comparação da intersecção (a) com $R_{f}$ (1-beta) deve proporcionar uma medida do desempenho da ação, pelo menos relativamente ao modelo de precificação de ativos de capital (CAPM), sendo que a regressão é calculada, algumas vezes, utilizando retornos extras da taxa livre de risco, tanto para a ação quanto para o mercado. Nesse caso, a intersecção da regressão deve ser: 
a) zero se os retornos reais forem iguais aos retornos esperados do CAPM, logo a $=\mathrm{R}_{\mathrm{f}}(1-$ beta $)$;

b) maior do que zero se a ação for melhor do que o esperado, logo a $>R_{f}$ (1beta);

c) menor do que zero se a ação for pior do que o esperado, logo $a<R_{f}$ (1-beta).

Assim como o retorno esperado sobre os ativos da empresa é a média ponderada dos retornos esperados sobre os títulos individuais, conforme demonstrado em (4.2) neste capítulo, do mesmo modo o beta dos ativos de uma empresa por definição é a média ponderada dos betas da estrutura de capital, dada pela seguinte equação:

$$
\beta_{A}=\left(\frac{\mathrm{D}}{\mathrm{D}+\mathrm{E}} X \beta_{D}\right)+\left(\frac{\mathrm{E}}{\mathrm{D}+\mathrm{E}} X \beta_{E}\right)
$$

em que:

$$
\begin{aligned}
& \beta_{A}=\text { beta dos ativos; } \\
& \frac{\mathrm{D}}{\mathrm{D}+\mathrm{E}}=\text { proporção da dívida; } \\
& \beta_{D}=\text { beta da dívida; } \\
& \frac{\mathrm{E}}{\mathrm{D}+\mathrm{E}}=\text { proporção do patrimônio e } \\
& \beta_{E}=\text { beta do patrimônio. }
\end{aligned}
$$

Sendo:

- o beta dos ativos a média ponderada dos betas individuais dos recursos de terceiros (dívida) e recursos próprios (patrimônio);

- o beta da dívida é calculado de acordo com o custo da dívida após o imposto de renda, em relação a média do custo de dívida do mercado e 
- o beta do patrimônio é calculado de acordo com as taxas de retorno das ações, em relação a media das taxas de retorno do índice do mercado.

Pode-se refazer essa equação para dar uma expressão para $\beta_{E}$, o beta das ações de uma empresa alavancada. Segundo Oda (2004, p. 22), "as expressões empresa alavancada e beta alavancado, são de uso corrente em finanças e se referem a empresas que apresentam dívidas financeiras”. Portanto, essa expressão será:

$$
\beta_{E}=\beta_{A}+\frac{\mathrm{D}}{\mathrm{E}}\left(\beta_{A}-\beta_{D}\right)
$$

Partindo-se da hipótese que, todos os riscos da economia são assumidos pelos acionistas, ou seja, o beta da dívida é zero, e a dívida traz um benefício de impostos para a empresa, logo:

$$
\beta_{L}=\beta_{U}\left(1+(1-t)\left(\frac{\mathrm{D}}{\mathrm{VM}}\right)\right.
$$

em que:

$\beta_{L}=$ beta alavancado para a ação da empresa;

$\beta_{U}=$ beta não-alavancado da empresa, ou seja, o beta da empresa sem dívida;

$t=$ taxa de imposto de renda de grandes empresas e

$\frac{\mathrm{D}}{\mathrm{VM}}=$ índice de dívida / valor de mercado da ação.

Cabe ressaltar que o beta-não-alavancado de uma empresa é determinado pelo setor de atuação e também por sua alavancagem operacional. Logo, o beta da ação de uma empresa é determinado tanto pelo risco do setor de sua atuação quanto pelo montante de risco de alavancagem financeira que ela assumiu.

Tendo em vista que a alavancagem financeira multiplica o risco implícito em um negócio, acredita-se, conforme Damodaran (2004, p. 106), que as empresas que 
atuam em setores relativamente estáveis devem estar muito mais dispostas a buscar alavancagem financeira.

Nesse sentido, para demonstrar a relação entre alavancagem financeira e o risco conjuntural (risco sistemático) da empresa, Hamada (1972, p. 437) parte da fórmula dos ganhos auferidos pelos acionistas ordinários de uma empresa alavancada em um período qualquer:

$\mathrm{DIV}+\mathrm{GC}=(\mathrm{X}-\mathrm{J})(1-\mathrm{t})-\mathrm{DIVP}+\Delta \mathrm{G}$

sendo:

DIV: Dividendos pagos aos acionistas ordinários ;

GC: Ganho (ou perda) de capital dos acionistas ordinários, correspondente à variação no preço das ações ordinárias;

X: Lucro operacional do período;

J: Juros incorridos durante o período;

t: Alíquota de imposto de renda;

DIVP: Dividendos pagos aos acionistas preferenciais;

$\Delta \mathrm{G}$ : Variação no crescimento capitalizado (capitalized growth) da empresa. O crescimento capitalizado corresponde ao valor presente dos fluxos de caixa futuro dos investimentos realizados antes do período que ainda não se realizaram, mas já estão refletidos nos preços das ações. Conforme Modigliani e Miller (1966, p. 371), o valor do crescimento capitalizado depende da rentabilidade das oportunidades futuras, de seu montante e do período de tempo durante o qual irão perdurar.

Portanto, é de se esperar que, durante o período, parte desses fluxos se realizem, assim como novos investimentos sejam realizados e, dessa forma, ocorra uma variação no crescimento capitalizado.

O beta da empresa alavancada $\left(\beta_{\mathrm{L}}\right)$ é dado por: 
$\beta_{\mathrm{L}}=\frac{\operatorname{cov}\left(i_{L} ; \dot{i}_{M}\right)}{\operatorname{var}\left(i_{M}\right)}$

em que:

$i_{L}$ : Taxa de retorno das ações ordinárias da empresa alavancada e

$i_{M}$ : Taxa de retorno do portfolio de mercado.

A taxa de retorno das ações ordinárias da empresa alavancada é dada por:

$$
i_{L}=\frac{\mathrm{DIV}+\mathrm{GC}}{\mathrm{n}_{\mathrm{L}} \cdot \mathrm{p}_{\mathrm{L}}}=\frac{(\mathrm{X}-\mathrm{J})(1-\mathrm{t})-\mathrm{DIVP}+\Delta \mathrm{G}}{\mathrm{n}_{\mathrm{L}} \cdot \mathrm{p}_{\mathrm{L}}}
$$

em que:

$\mathrm{n}_{\mathrm{L}}$ : quantidade de ações ordinárias da empresa alavancada e

$\mathrm{p}_{\mathrm{L}}$ : preço das ações ordinárias da empresa alavancada no início do período.

Substituindo (4.27) em (4.26), tem-se:

$\beta_{\mathrm{L}}=\frac{\operatorname{cov}\left(\frac{\mathrm{DIV}+\mathrm{GC}}{\mathrm{n}_{\mathrm{L}} \cdot \mathrm{p}_{\mathrm{L}}}\right)}{\operatorname{var}\left(\mathrm{i}_{\mathrm{M}}\right)}=\frac{\left.\operatorname{cov}(\mathrm{X}-\mathrm{J})(1-\mathrm{t})-\mathrm{DIVP}+\Delta \mathrm{G} ; \mathrm{i}_{\mathrm{M}}\right)}{\mathrm{n}_{\mathrm{L}} \cdot \mathrm{p}_{\mathrm{L}} \cdot \operatorname{var}\left(\mathrm{i}_{\mathrm{M}}\right)}$

Analogamente, se a empresa não tivesse dívidas nem ações preferenciais, o seu beta não-alavancado $\left(\beta_{U}\right)$ seria dado por:

$$
\begin{aligned}
& \beta_{U}=\frac{\operatorname{cov}\left(\frac{D I V+G C}{n_{U} \cdot p_{U}} ; i_{M}\right)}{\operatorname{var}\left(i_{M}\right)}=\frac{\operatorname{cov}\left(X(1-t)+\Delta G ; \dot{1}_{M}\right)}{n_{U} \cdot p_{\cup} \cdot \operatorname{var}\left(i_{M}\right)} \hat{U} \\
& \Leftrightarrow n_{U} \cdot p_{U} \cdot \beta_{U}=\frac{\operatorname{cov}\left(X(1-t) i_{M}\right)}{\operatorname{var}\left(i_{M}\right)}+\frac{\operatorname{cov}\left(\Delta G ; i_{M}\right)}{\operatorname{var}\left(i_{M}\right)}
\end{aligned}
$$


em que:

$\mathrm{n}_{\mathrm{U}}$ : quantidade de ações ordinárias da empresa não-alavancada e

$\mathrm{p}_{\mathrm{u}}$ : preço das ações ordinárias da empresa não-alavancada no início do período.

Expandindo a equação (4.29), tem-se para a empresa não-alavancada:

$\mathrm{n}_{\mathrm{L} .} \mathrm{p}_{\mathrm{L} .} \beta_{\mathrm{L}}=\frac{\operatorname{cov}\left(\mathrm{X}(1-\mathrm{t}) ; \dot{\mathrm{i}}_{\mathrm{M}}\right)}{\operatorname{var}\left(\mathrm{i}_{\mathrm{M}}\right)}-\frac{\operatorname{cov}\left(\mathrm{j}(1-\mathrm{t}) ; \dot{\mathrm{i}}_{\mathrm{M}}\right)}{\operatorname{var}\left(\mathrm{i}_{\mathrm{M}}\right)}-\frac{\operatorname{cov}\left(\mathrm{DIVP} ; \dot{\mathrm{i}}_{\mathrm{M}}\right)}{\operatorname{var}\left(\mathrm{i}_{\mathrm{M}}\right)}+\frac{\operatorname{cov}\left(\Delta \mathrm{G} ; \dot{\mathrm{i}}_{\mathrm{M}}\right)}{\operatorname{var}\left(\mathrm{i}_{\mathrm{M}}\right)}$

Mas, considerando que os juros e os dividendos preferenciais são fixos e conhecidos no inicio do período, tem-se que suas covariâncias com o retorno do portfolio de mercado são zero. Assim:

$\mathrm{n}_{\llcorner.} \mathrm{p}_{\mathrm{L} .} \beta_{\mathrm{L}}=\frac{\operatorname{cov}\left(\mathrm{X}(1-\mathrm{t}) ; \dot{\mathrm{i}}_{\mathrm{M}}\right)}{\operatorname{var}\left(\mathrm{i}_{\mathrm{M}}\right)}+\frac{\operatorname{cov}\left(\Delta \mathrm{G} ; \dot{\mathrm{i}}_{\mathrm{M}}\right)}{\operatorname{var}\left(\mathrm{i}_{\mathrm{M}}\right)}$

Assumindo-se que o resultado operacional e o crescimento capitalizado não dependem da estrutura de capital da empresa, tem-se que o lado direito das equações (4.29) e (4.31) é igual e portanto:

$\mathrm{N}_{\mathrm{U}} \cdot \mathrm{p}_{\mathrm{U}} \cdot \beta_{\mathrm{L}}=\mathrm{n}_{\mathrm{L}} \cdot \mathrm{p}_{\mathrm{L}} \cdot \beta_{\mathrm{L}}$

O produto da quantidade de ações ordinárias por seu preço corresponde ao valor da empresa pertencente aos acionistas ordinários (VA). Assim:

$V A_{U} \cdot \beta_{U}=V A_{L} \cdot \beta_{L}$

em que:

$V A_{L}$ : valor das ações ordinárias da empresa alavancada; e

VA $A_{U}$ valor das ações ordinárias caso a empresa não tivesse dívidas.

Como se partiu de uma empresa com dívidas, VA não pode ser observado. No entanto, a primeira (I) proposição de Modigliani e Miller (1963, p. 437) com impostos postula que: 
$V A_{U}=V E_{L}-t . D$

em que:

D: valor de mercado das dívidas da empresa alavancada;

$V_{\mathrm{L}}$ : valor da empresa alavancada e

t: alíquota de imposto de renda aplicada à empresa.

Logo, o valor da empresa alavancada é dado pela soma dos valores de mercado das ações ordinárias, preferenciais e das dívidas:

$V E_{L}=V A_{L}+V P_{L}+D$

em que:

$\mathrm{VP}_{\mathrm{L}}$ : valor das ações preferenciais da empresa alavancada

Substituindo (4.34) e (4.35) em (4.33), tem-se:

$$
\begin{aligned}
& \left(\mathrm{VA}_{\mathrm{L}}+\mathrm{VP}_{\mathrm{L}}+\mathrm{D}-\mathrm{t} . \mathrm{D}\right) . \beta_{\mathrm{U}}=\mathrm{VA}_{\mathrm{L}} \cdot \beta_{\mathrm{L}} \Leftrightarrow \\
& \Leftrightarrow \beta_{\mathrm{L}}=\beta_{\mathrm{U}}\left(1 \frac{\mathrm{VP}_{\mathrm{L}}+\mathrm{D}(1-\mathrm{t})}{\mathrm{VA}_{\mathrm{L}}}\right)
\end{aligned}
$$

A equação (4.36) demonstra de acordo com Oda (2004, p. 26), que quanto maior a relação entre ações preferenciais + dividas e o capital próprio, maior será o beta das ações ordinárias. Segundo o mesmo autor, "considerando que a empresa tenha estrutura de capital composta apenas por ações ordinárias e dívida, tem-se a tradicional fórmula de "alavancagem do beta", bastante utilizada na pratica em trabalhos de avaliação de empresas", conforme Copeland et al. (2002, p. 316):

$$
\beta_{\mathrm{L}}=\beta_{\mathrm{U}}\left(1+\frac{\mathrm{D}}{\mathrm{VA}_{\mathrm{L}}}(1-\mathrm{t})\right)
$$

em que: 
$\beta_{u}$ : beta da empresa não-alavancada;

$\beta_{\mathrm{L}}$ : beta da empresa alavancada;

D: valor de mercado das dívidas da empresa alavancada e

$V A_{L}$ : valor das ações ordinárias da empresa alavancada.

Nesse sentido, Mandelker e Rhee (1984, apud Garrod e Mramor, 2000) concluíram um modelo teórico onde o beta alavancado da empresa é função de seu grau de alavancagem operacional e financeira e do risco intrínseco do negócio.

Reforçando essa teoria, o beta de uma empresa, conforme Damodaran (2004, p. 102), é determinado por três variáveis:

1) tipo de negócio em que a empresa está investindo;

2) grau de alavancagem operacional e

3) grau de alavancagem financeira.

1) Tipo de negócio: Tendo em vista que os betas mensuram o risco intrínseco de uma empresa em relação a um índice de mercado, quanto mais sensível for um negócio em relação às condições de mercado, mais alto será o seu beta.

Portanto, as empresas que são menos sensíveis a ciclos conjunturais da atividade econômica (risco sistemático), devem possuir betas mais baixos, em relação às empresas que são mais sensíveis a ciclos conjunturais da economia. Seguindo essa linha de pensamento, afirma-se que o grau em que um produto é supérfluo afetará o beta da empresa que fabrica esse produto.

2) Grau de alavancagem operacional: Uma empresa que tem uma elevada alavancagem operacional, ou seja, custos fixos altos relativos à soma total de custos, também terá uma volatilidade mais alta em receitas antes dos juros e 
do imposto de renda, termo conhecido em finanças como EBIT (Earning Before Interest Taxes).

É importante ressaltar que os custos e despesas fixos não significam valores constantes (fixos). Sua relação não está vinculada com o volume de atividade (vendas e produção) e sim com o tempo. Mantendo-se inalterados diante de variações nas vendas ou da produção, os gastos são considerados fixos mesmos que seus valores sofram modificações periódicas.

3) Grau de alavancagem financeira: Não havendo alteração de fatores, a elevação na alavancagem financeira aumentará o beta das ações de uma empresa. Ora, automaticamente os pagamentos da dívida aumentam a variância do lucro líquido, com uma alavancagem maior elevando o lucro durante os momentos de crescimento econômico e diminuindo o lucro durante períodos de baixo crescimento econômico.

Logo, o uso da alavancagem financeira normalmente reflete a expectativa de maiores retornos esperados pelos investidores, ao mesmo tempo em que, conseqüentemente, aumenta seu risco.

\subsection{0 - Dados Obtidos da Demonstração de Resultados do Exercício}

Índice de Cobertura de Juros $\left(\mathrm{I}_{\mathrm{CJ}}\right)$ :

- Demonstra a capacidade da empresa de atender às suas obrigações com despesas financeiras. Logo, é o índice do lucro antes dos juros e impostos (LAJIR) em relação às despesas financeiras.

- O índice de cobertura de juros pode ser apurado pela fórmula:

$$
\mathrm{I}_{\mathrm{CJ}}=\frac{\text { LAJIR }}{\text { Despesas Financeiras }}
$$


Índices de Lucratividade:

- Demonstram o retorno obtido sobre o investimento realizado pelos supridores de capital. O objetivo é avaliar o lucro da empresa com o patrimônio líquido e investimento. Logo, os índices de lucratividade constituem uma série de índices que mostram os efeitos combinados da liquidez, da administração de ativos e da administração da dívida sobre os resultados operacionais.

Os principais índices de lucratividade analisados são:

Retorno sobre os Ativos Totais ou Return on Asset - ROA

- Mensura a eficiência global da empresa em gerar lucros com seus ativos, ou seja, é o índice da renda líquida para com os ativos totais e mede o retorno sobre os ativos totais.

- O retorno sobre os ativos totais pode ser apurado pela fórmula:

$$
\text { ROA }=\frac{\text { Lucro Líquido }}{\text { Ativo Total }}
$$

Retorno sobre o Patrimônio Líquido ou Return on Equity - ROE

- Mensura a eficiência global da empresa em gerar lucros sobre o investimento realizado pelos acionistas, ou seja, mede a taxa de retorno sobre o capital próprio.

- O retorno sobre o patrimônio líquido pode ser apurado pela fórmula:

$$
\text { ROE }=\frac{\text { Lucro Líquido }}{\text { Patrimônio Líquido }}
$$




\subsection{1 - As Demonstrações dos Fluxos de Caixa da Empresa}

O fluxo de caixa visa a demonstrar o acréscimo financeiro da empresa em determinado período, no qual o seu saldo contemplará todos os valores que se realizam a curto prazo, isto é, em menos de noventa dias (caixa ou equivalente de caixa), podendo ser apurado de forma direta ou indireta.

Pelo método direto são apuradas as variações nos saldos das contas patrimoniais que representaram ingresso ou saída de caixa.

Pelo método indireto, mais utilizado, a base é o lucro líquido do período, ajustando-o aos valores econômicos (que não representaram ingresso ou saída de recursos), bem como às variações nas contas patrimoniais modificativas de caixa.

\subsection{1 - Fluxo de Caixa Operacional (FCO)}

As atividades operacionais estão diretamente relacionadas às operações da empresa, como aos valores econômicos apresentados no resultado líquido (despesas com depreciação e amortização, resultado de equivalência patrimonial, despesas com créditos de liquidação duvidosa), variações nos saldos de contas a receber, a pagar, estoques e salários a pagar.

O fluxo de caixa operacional define a liquidez das empresas, ou seja, se elas são capazes de gerar, a partir de suas operações internas, dinheiro suficiente para realizar o serviço de suas dívidas.

Sendo que o FCO: mede o caixa gerado ou consumido pela empresa como resultado de sua produção e venda de bens e serviços e a geração de fluxos de caixa operacionais positivos é essencial para a sobrevivência da empresa. 
Quadro 14 - Estrutura da Demonstração do Fluxo de Caixa Operacional

\begin{tabular}{|l|}
\hline Fluxo de Caixa Operacional (FCO) \\
Lucro Líquido do Período \\
+ Despesas Não Desembolsáveis (Depreciação, Amortização) \\
+Variações nas Contas Operacionais \\
-(Aumento) + (Diminuição) Contas a Receber \\
-(Aumento) + (Diminuição) Estoques \\
-(Diminuição) + (Aumento) Contas a Pagar \\
-(Diminuição) + (Aumento) Impostos a Pagar \\
-(Diminuição) + (Aumento) Adiantamento Consumidores
\end{tabular}

Fonte: Adaptado de Assaf (2002, p. 42)

\subsection{2 - Fluxo de Caixa de Financiamento (FCF)}

Nas atividades de financiamento encontram-se os valores captados pela empresa visando à aplicação desses recursos obtidos na atividade interna do seu negócio, como empréstimos bancários e emissão de títulos de dívida.

Sendo que o FCF: representa o fluxo de caixa decorrente das decisões de estrutura de capital da empresa (dívida/capital próprio) e inclui as receitas provenientes de novas captações e os gastos com pagamento de dívidas e dividendos.

Quadro 15 - Estrutura da Demonstração do Fluxo de Caixa de Financiamento

\begin{tabular}{|l|}
\hline Fluxo de Caixa de Financiamento (FCF) \\
\hline -(Diminuição) + (Aumento) Dívidas de Curto Prazo \\
-(Diminuição) + (Aumento) Dívidas de Longo Prazo \\
-(Diminuição) + (Aumento) Ações Ordinárias \\
-Dividendos Pagos \\
-(Diminuição) + (Aumento) PL (exceto lucros retidos)
\end{tabular}

Fonte: Adaptado de Assaf (2002, p. 42) 


\subsection{2 - Operacionalização das Variáveis}

Os dados necessários à realização da pesquisa serão, para cada empresa que realizou a securitização de recebíveis, os dados da DRE - Demonstração de Resultados e respectivos Balanços Patrimoniais.

As variáveis utilizadas para a pesquisa serão os principais indicadores financeiros, os graus de alavancagem (GAT,GAF e GAO) e beta de mercado e o comportamento do rating de crédito estabelecido pelas empresas de classificação de rating.

Os rating de crédito pesquisados nessa pesquisa, foram os ratings disponíveis e mensurados pelas empresas que oferecem tais serviços no mercado brasileiro, ou seja, os divulgados por Moody's Investors Service, Fitch IBCA Investors Service e Standard \& Poor's.

Foram calculados os indicadores, descritos a seguir, de acordo com os dados coletados na pesquisa no sistema Economática, para cada ano. A partir disso, foram calculados os mesmos indicadores, considerando o impacto do efeito da securitização nos respectivos indicadores analisados, ou seja, antes da realização da securitização e após o início da securitização de ativos.

\subsection{3 - Tratamento dos Dados}

O tratamento dos dados envolveu o cálculo de todos os indicadores descritos na seção anterior utilizando, para isso, as planilhas eletrônicas Microsoft Excel. As análises estatísticas foram realizadas utilizando-se os softwares SPSS-12 e o Matlab-15.

\subsection{4 - Modelos Estatísticos Utilizados}

\subsection{1 - Coeficiente de Correlação de Pearson}

Conforme Stevenson (2001, p. 368), a forma mais comum de análise de correlação envolve dados contínuos. O grau de relacionamento entre duas variáveis contínuas 
é sintetizado por um coeficiente de correlação conhecido como " $R$ de Pearson", em homenagem ao grande matemático Karl Pearson, que desenvolveu essa metodologia.

O coeficiente de correlação de Pearson mede "o grau de dispersão conjunta e de associação linear entre duas varáveis aleatórias" (FONSECA e MARTINS, 1996, p. 57). Nesse sentido, para dados paramétricos, a análise estatística mais utilizada, para obtenção da correlação entre variáveis é o coeficiente de (Karl) Pearson.

Segundo Stvenson (2001, p. 368), essa técnica é válida quando se verificam duas condições:

(1) Tanto $X$ com $Y$ são variáveis aleatórias contínuas. Isto é, ao contrário da análise de regressão, não se aceita selecionar certos valores de $x \mathrm{e}$ depois avaliar $Y$ : tanto $Y$ como $X$ devem variar livremente (isto é, serem considerados "como são") e

(2) A distribuião de freqüência conjunta (isto é, a distribuição de valores dos pares $X, Y$ ) é normal. É o que se chama distribuição normal bivariada.

De acordo com Oda (2004, p. 92), "o valor desse coeficiente vária entre -1 e +1 , sendo que quanto maior o valor absoluto maior é a associação entre variáveis". Por exemplo, valores de $R$ próximos de $-1,00$ ou $+1,00$ indicam que tais valores estão muito próximos da reta, ou mesmo sobre a reta, enquanto os valores mais próximos de zero, ou $R=0$ sugerem maior dispersão.

Exemplo: Valor de $R+1,00$

Gráfico 10 - Diagrama de dispersão: Relacionamento positivo, perfeito y

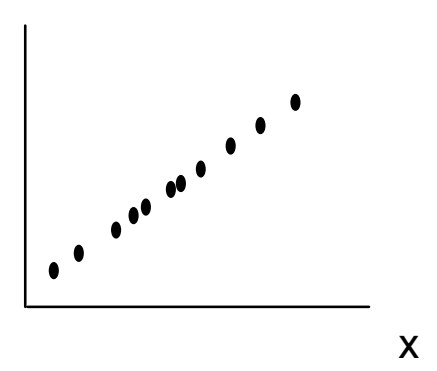

Fonte: Stevenson (2001, p. 369) 
Variáveis com correlação positiva ( $R$ é + ), indicam que a valores altos (baixos) de uma das variáveis correspondem a valores altos (baixos) da outra.

Exemplo: Valor de $R$ cerca de $+0,70$

Gráfico 11 - Diagrama de dispersão: Relacionamento positivo, moderado y

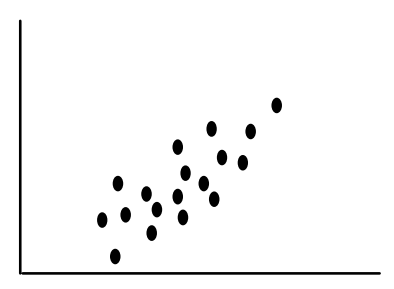

$\mathrm{X}$

Fonte: Stevenson (2001, p. 369)

Variáveis com correlação negativa ( $R$ é -), indicam que valores altos (baixos) de uma variável correspondem a valores baixos (altos) da outra.

Exemplo: Valor de $R$ cerca de $-0,70$

Gráfico 12 - Diagrama de dispersão: Relacionamento negativo, moderado

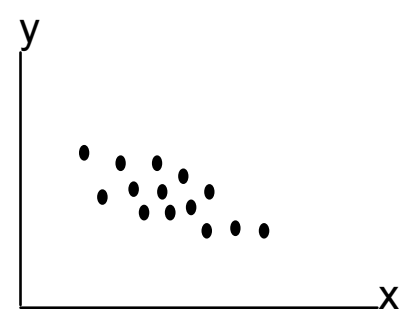

Fonte: Stevenson (2001, p. 369)

Variáveis com correlação igual a zero $(R=0)$ indicam que alguns valores altos estão em correspondência com valores baixos e outros estão em correspondência com valores altos. 
Exemplo: Valor de $R=0$

\section{Gráfico 13 - Diagrama de dispersão: Ausência de relacionamento}

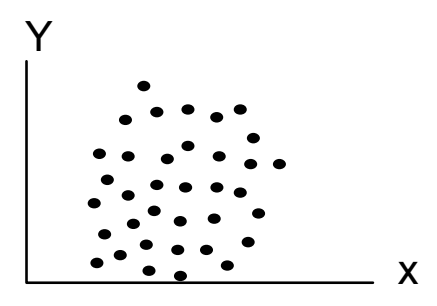

Fonte: Stevenson (2001, p. 369)

Conforme Stvenson (2001, p. 368), o coeficiente de correlação possui duas propriedades que caracterizam a natureza de uma relação entre duas variáveis. Uma é o seu sinal (+ ou -) e a outra é sua magnitude de $R$ que indica como próximos da reta estão os pontos individuais. Nesse sentido, um valor absoluto próximo de zero indica nenhuma associação linear. Enquanto um valor absoluto próximo de 1 indica uma forte associação, e um valor absoluto próximo a -1 indica uma fraca associação linear entre as variáveis.

A covariância e o coeficiente de correlação medem a intensidade da relação linear (eventualmente) existente entre duas variáveis aleatórias.

O coeficiente de Pearson mede o grau de assimetria por meio da correlação de média e da moda. Sua fórmula está apresentada, a seguir:

$$
\rho_{\mathrm{XY}}=\frac{\operatorname{Cov}(\mathrm{X}, \mathrm{Y})}{\sqrt{\operatorname{Var}(\mathrm{X}) \operatorname{Var}(\mathrm{Y})}}
$$

em que:

$$
\begin{aligned}
& \left|\rho_{X Y}\right|=1 \Rightarrow \quad \text { Variáveis linearmente dependentes; } \\
& \rho_{X Y}=\operatorname{Cov}(X, Y)=0 \Rightarrow \text { Variáveis linearmente independentes. }
\end{aligned}
$$


A equação anterior pode ser reescrita como:

$$
\mathrm{A}_{\mathrm{s}}=\frac{\mathrm{N} \sum \mathrm{xy}-\left(\sum \mathrm{y}\right)\left(\sum \mathrm{x}\right.}{\left.\sqrt{\left[\mathrm{N} \sum \mathrm{x}^{2}\right.}-\left(\sum \mathrm{x}\right)^{2}\right]\left[\mathrm{N} \sum \mathrm{y}^{2}-\left(\sum \mathrm{y}\right)^{2}\right]}
$$

em que:

\begin{tabular}{|l|}
\hline $\mathrm{A}_{\mathrm{s}}=0$ a distribuição é simétrica \\
\hline $\mathrm{A}_{\mathrm{s}}>0$ a distribuição é assimétrica positiva \\
\hline $\mathrm{A}_{s}<0$ a distribuição é assimétrica negativa \\
\hline
\end{tabular}

Quando não se dispõe da média nem do desvio-padrão, Pearson definiu um outro coeficiente que permite calcular o grau de assimetria de uma distribuição utilizando, apenas, os quartis da distribuição e sua fórmula é descrita, a seguir:

$$
\mathrm{A}_{\mathrm{s}}=\frac{\left(\mathrm{Q} 3+\mathrm{Q} 1-2 \mathrm{M}_{\mathrm{d}}\right)}{\mathrm{Q} 3-\mathrm{Q} 1}
$$

Nessa pesquisa, o coeficiente de correlação de Pearson foi empregado diversas vezes para verificar se existe associação entre variáveis, no entanto, a utilização dessa técnica pressupõe a assunção da hipótese distribuição normal bivariada para as variáveis em estudo. Desse modo, para aumentar a confiabilidade dos testes optou-se, também, pela inclusão de uma medida de associação não-paramétrica (ordinais): o coeficiente de correlação de Spearman. 


\subsection{2 - Coeficiente de Correlação de Spearman}

O coeficiente de correlação de Spearman mede a associação linear entre:

- Duas variáveis qualitativas $X$ e $Y$ ordinais.

- Duas variáveis quantitativas que não seguem uma Distribuição Normal.

Uma variável qualitativa é classificada segundo sua mensuração em: nominal ou ordinal. Uma variável qualitativa é nominal quando suas categorias não apresentam uma relação de ordem entre si. O número de categorias de uma variável indica a quantidade de classes utilizadas na sua observação no teste de hipóteses.

Esse teste de hipóteses é realizado para avaliar a associação entre duas variáveis qualitativas e ordinais, sendo expresa essa associação pelo coeficinete de correlação de Spearman $\left(R_{s p}\right)$.

Nesse sentido, esse teste trabalha com as seguintes hipóteses:

- $\quad \mathrm{H}_{0}$ : as variáveis não estão associadas, isto é, $R_{s p}=0$.

- $\quad \mathrm{H}_{1}$ : as variáveis estão associadas, isto é, $R_{s p}$ é diferente de zero.

No teste de hipóteses se houver um sentido esperado da associação, ou seja, ou associação positiva ou associação negativa, então o teste é considerado unilateral. Caso não houver um sentido esperado para a associação das variáveis, então o teste é considerado bilateral.

De acordo com Stevenson (2001, p. 382), "a correlação por postos de Spearman é uma técnica não-paramétrica para avaliar o grau de relacionamento entre observações emparelhadas de duas variáveis, quando os dados se dispõem em postos". O objetivo do cálculo de um coeficiente de correlação é determinar até que ponto dois conjuntos de postos concordam ou discordam. Norusis (1998, p. 411) complementa que o coeficiente de Spearman $\left(R_{s p}\right)$ é uma medida à ser utilizada quando os valores nominais são substituídos por posições relativas, por exemplo, rankings, e não requerem a hipótese de normalidade.

Segundo Stevenson (2001, p. 382), o cálculo da correlação utiliza a fórmula: 


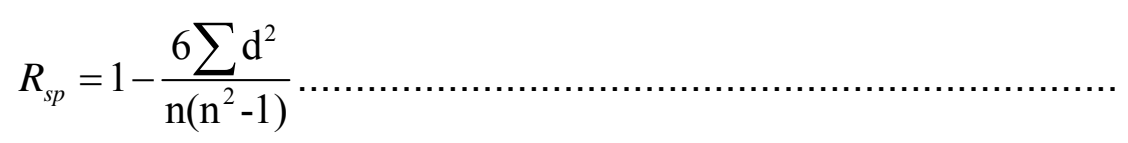

em que:

$R_{s p}=R$ de Spearman $=$ coeficiente de correlação das observações $\left(\mathrm{x}_{\mathrm{i}} ; \mathrm{y}_{\mathrm{i}}\right)$

$\mathrm{n}=$ número de observações

$\sum d^{2}=$ soma dos quadrados das diferenças entre as observações $\left(x_{i}-y_{i}\right)$

De acordo com Oda (2004, p. 93), "essa medida também varia entre -1 e +1 e sua interpretação é análoga à do coeficiente de correlação de Pearson", demonstrada na seção (4.12.1) anterior.

A decisão estatística pór uma das hipóteses testadas, se dá pela comparação adequada da probabilidade de significância ( $p$-value), calculada a partir dos dados amostrais, bem como pelo nível de significância $(\alpha)$ adotado na pesquisa. Após a obtenção dos resultados, conclui-se que:

- $\quad$ Se $p$-value for menor ou igual ao nível de significância $(\alpha)$, então rejeita-se $H_{0}$ e conclui-se que as variáveis estão associadas.

- $\quad$ Se $p$-value for maior que o nível de significância $(\alpha)$, então aceita-se $\mathrm{H}_{0}$ e não pode ser afirmada a associação das variáveis.

Esse coeficiente foi utilizado nesta pesquisa para verificar se existe relação entre: indicadores financeiros, beta de mercado e securitização de recebíveis.

\subsection{3 - Regressão por Mínimos Quadrados Ordinários}

Segundo Stevenson (2001, p. 347), "o método mais usado para ajustar uma linha reta a um conjunto de pontos é conhecido como técnica dos mínimos quadrados". Encontrar, ou estimar na verdade, a reta de regressão significa encontrar estimadores para $\alpha$ e $\beta$. 
Esse método é uma técnica de otimização matemática que busca encontrar o melhor ajuste para um conjunto de dados tentando minimizar a soma dos quadrados das diferenças entre a curva ajustada e os dados.

De acordo com Sartoris (2003, p. 236), as variáveis $X$ e $Y$ podem ser definidas da seguinte forma:

$$
\begin{aligned}
& x=X-\bar{X} \\
& y=Y-\bar{Y}
\end{aligned}
$$

As variáveis $X$ e $Y$ são centradas na média. Como a média dos erros é zero temse que, tomando as médias da equação da reta:

$$
\begin{aligned}
& Y_{i}=\alpha+\beta X_{i}+\varepsilon_{i} \\
& \bar{Y}=\alpha+\beta \bar{X}+0
\end{aligned}
$$

E se for subtraída a segunda equação da primeira:

$$
\begin{aligned}
& Y_{i}-\bar{Y}=(\alpha-\alpha)+\beta\left(X_{i}-\bar{X}\right)+\varepsilon_{i} \\
& y_{i}=\beta X_{i}+\varepsilon_{i}
\end{aligned}
$$

Logo, o método utilizado pressupõe que se quer estimar uma reta que tenha menos erro. Então, a melhor reta será aquela cuja soma dos quadrados dos erros for mínima. Daí decorre o nome: método dos mínimos quadrados, Sartoris (2003, p. 236).

Da equação da reta, usando as variáveis centradas, os erros serão dados por:

$$
\varepsilon_{\mathrm{i}}=\mathrm{y}_{\mathrm{i}}-\beta \mathrm{x}_{\mathrm{i}}
$$

A soma dos quadrados dos erros será:

$$
\sum_{\mathrm{i}=1}^{\mathrm{n}}\left(\varepsilon_{\mathrm{i}}\right)^{2}=\sum_{\mathrm{i}=1}^{\mathrm{n}}\left(\mathrm{y}_{\mathrm{i}}-\beta \mathrm{x}_{\mathrm{i}}\right)^{2}
$$

Ou, omitindo os índices i $=1$ a n ter-se-á: 


$$
\begin{aligned}
& \sum \varepsilon_{\mathrm{i}}^{2}=\sum\left(\mathrm{y}_{\mathrm{i}}-\beta \mathrm{x}_{\mathrm{i}}\right)^{2} \\
& \sum \varepsilon_{\mathrm{i}}^{2}=\sum\left(\mathrm{y}_{\mathrm{i}}^{2}+\beta^{2} \mathrm{x}_{\mathrm{i}}^{2}-2 \beta \mathrm{x}_{\mathrm{i}} \mathrm{y}_{\mathrm{i}}\right)
\end{aligned}
$$

Utilizando as propriedades da soma resulta:

$$
\sum \varepsilon_{\mathrm{i}}^{2}=\sum \mathrm{y}_{\mathrm{i}}^{2}+\sum \beta^{2} \mathrm{x}_{\mathrm{i}}^{2}-2 \sum \beta \mathrm{x}_{\mathrm{i}} \mathrm{y}_{\mathrm{i}}
$$

Sendo beta uma constante em todo o somatório obtêm-se:

$$
\sum \varepsilon_{\mathrm{i}}^{2}=\sum \mathrm{y}_{\mathrm{i}}^{2}+\beta^{2} \sum \mathrm{x}_{\mathrm{i}}^{2}-2 \beta \sum \mathrm{x}_{\mathrm{i}} \mathrm{y}_{\mathrm{i}}
$$

Para encontrar o valor de $\beta$ que forneça o mínimo dessa soma, o procedimento é derivar e igualar a zero. Como esse valor de $\beta$ é um estimador, será utilizado o $\widehat{\beta}$.

Ter-se-á, então:

$$
2 \widehat{\beta} \sum \mathrm{x}_{\mathrm{i}}^{2}-2 \sum \mathrm{x}_{\mathrm{i}} \mathrm{y}_{\mathrm{i}}=0
$$

Dividindo por dois em ambos os lados:

$$
\begin{aligned}
& \hat{\beta} \sum \mathrm{x}_{\mathrm{i}}^{2}-\sum \mathrm{x}_{\mathrm{i}} \mathrm{y}_{\mathrm{i}}=0 \\
& \hat{\beta}=\frac{\sum \mathrm{x}_{\mathrm{i}} \mathrm{y}_{\mathrm{i}}}{\sum \mathrm{x}_{\mathrm{i}}^{2}}
\end{aligned}
$$

O estimador para $\alpha$ pode ser encontrado na equação da reta para as médias:

$$
\overline{\mathrm{Y}}=\alpha+\beta \overline{\mathrm{X}}
$$

Substituindo pelos respectivos estimadores:

$$
\overline{\mathrm{Y}}=\widehat{\alpha}+\widehat{\beta} \overline{\mathrm{X}}
$$

Portanto:

$$
\bar{\alpha}=\bar{Y}-\bar{\beta} \bar{X}
$$

Segundo, Stevenson (2001, p. 347), o método mais utilizado para ajustar uma linha reta a um conjunto de pontos é conhecido como Técnica dos Mínimos Quadrados. 
Conforme Johnston e Dinardo (1999, p. 69), o método de Mínimos Quadrados Ordinários - MQO ou (Ordinary Least Squares - OLS) é o método mais simples e tradicional de estimação, em que se identificam $K-1$ variáveis explanatórias (regressores) $X_{2}, X 3, \ldots \ldots X_{n}$, que influenciam a variável dependente $Y$ e $E$ é o termo de erro. Logo, a reta resultante terá duas características importantes: (1) a soma dos desvios verticais dos pontos em relação à reta é zero e (2) a soma dos quadrados desses desvios será mínima.

De acordo com Oda (2004, p. 94), "há 5 considerações necessárias para que as estimativas pelo método dos mínimos quadrados sejam consistentes e, se não forem respeitadas, podem levar a estimativas enviesadas":

1) O relacionamento pode ser expresso de forma linear;

2) Os erros são não-correlacionados com os regressores;

3) Os regressores são linearmente independentes (não-multicolinearidade);

4) Os erros são não-autocorrelacionados e apresentam variância constante e

5) A distribuição dos erros é normal.

Ainda, segundo o mesmo autor, "se isso não ocorrer, os intervalos de confiança dos coeficientes estarão comprometidos, uma vez que o nível de significância ou a rejeição estará comprometida".

\subsection{4 - Análise Estatística Fuzzy e Implicativa}

A lógica fuzzy é baseada na teoria dos conjuntos nebulosos. É a lógica que serve de base para expressar as formas vagas e imprecisas, ao invés das formas matemáticas convencionais precisas. Os conceitos de lógica fuzzy podem ser usados para traduzir informações inexatas, contidas na linguagem natural, para termos matemáticos abstratos.

Nesse contexto, a lógica fuzzy, de acordo com Zadeh (1965, p. 338) é baseada na teoria dos conjuntos nebulosos, ou seja, é a lógica que serve de base para as 
formas de raciocínio que são nebulosas, ao invés de precisas. Os conceitos de lógica fuzzy podem ser usados para traduzir informação inexata, contida na linguagem natural, para termos matemáticos. A abordagem fuzzy foi aplicada, por exemplo, no modelo econômico de Deinichenko et al. (1996, p. 157) e em finanças, de acordo com Couturier (2000, p. 17), bem como em contabilidade conforme Antunes (2006, p. 80).

$\mathrm{Na}$ lógica tradicional proposicional, premissas não relacionadas entre si podem ser combinadas para formar uma implicação, mesmo que não exista nenhuma relação causa-efeito, mas, relações causa-efeito acontecem no mundo real e em aplicações da engenharia, finanças e outras áreas. A extensão da lógica tradicional para a lógica fuzzy foi possível por meio da simples substituição das funções de relevância de primeiro grau por funções de relevância fuzzy, até a semelhança de extensão de conjuntos usuais para conjuntos nebulosos. A função de relevância mede o grau de verdade da relação de implicação entre $x$ e $y$.

De acordo com Antunes (2006, p.83) "a proposta da lógica nebulosa é assumir uma premissa que varia em grau de pertinência, no intervalo de 0 a 1 , o que leva o elemento do conjunto nebuloso a ser parcialmente verdadeiro, ou parcialmente falso".

Os operadores de implicação (relação) são usados para implementar regras de inferência (limitações relacionais): "se (premissa) então (conclusão)" conforme Zadeh (1973, p. 29). Para verificar até que ponto a premissa implica na conclusão, dados os valores reais, será possível constatar o grau de implicação. Por serem mais gerais do que funções, elas permitem que dependências entre variáveis sejam capturadas sem necessariamente pertencerem a nenhuma caracterização direcional específica dessas variáveis.

Observa-se que o uso de expressões de implicação convencionais, inspirado na lógica tradicional, tira conclusões sem sentido quando a abordagem relaciona-se a aplicações da engenharia, em que a noção de causa-efeito é importante, conforme destacado em Mendel (1995, p. 355). Devido a isso, a necessidade fez com que essas implicações fossem definidas para capturar e preservar causa e efeito, criando a ruptura com a lógica proposicional tradicional. Os primeiros problemas de 
aplicação da lógica fuzzy, conforme Lee (1990, p. 410) apareceram na área de Engenharia de Controle, quando min e prod (produto) passaram a representar as implicações que têm sido, desde então, extremamente usadas na engenharia.

A implicação, segundo Gras et al. (1997, p. 412) é apresentada como uma nova abordagem com suas próprias características. A noção de implicação estatística é baseada na comparação estatística entre a inclusão de conjuntos observados em uma população e outra que teria conjuntos comparáveis, mas, escolhidos casualmente na mesma população.

Entretanto, a perda de discriminação da intensidade da implicação, no caso de amostras significativamente grandes levou Gras (1996, p. 38) a definir outra medida da implicação, levando em conta o seu oposto. Destaca-se a necessidade de referirse em um só momento à implicação direta e ao seu oposto, caso alguém tenta colocar em evidência não somente a função descritiva que a implicação direta assegura, mas, também, a função causal associada à noção comum de implicação. De acordo com Spagnolo e Gras (2004, p. 3), isso permite influenciar a intensidade da implicação com maior poder de discriminação, com mais informação e de uma maneira mais próxima do senso do coeficiente moderador de implicação.

A pesquisa de regras parciais entre atributos observados numa população é geralmente expressa em termos de probabilidade condicional $(P(B / A))$. A intuição de Gras sugere o seguinte modelo de implicação: uma variável "A" que tem sobre outra variável "B" (regra $a=>$ b) e não seria totalmente satisfatória pode ser aceita como especialmente válida, uma vez que o conjunto dos sujeitos que estão presentes em "A" contenha tópicos que estejam presentes em "B".

As declarações condicionais são denominadas regras (lingüísticas) e são, normalmente, frases da forma Se ( $x$ é A) então (y é B). Essa frase, normalmente denominada implicação, pode ser reduzida a uma proposição fuzzy binária $((x, y)$ é $R A-B)$ ).

Quando uma declaração condicional apresenta mais de uma variável antecedente ( $\mathrm{x}$ é A), essas variáveis são combinadas por meio do conectivo E. Algumas declarações podem ser combinadas por meio do conectivo OU. 
Relações fuzzy, conforme descritas em Zadeh (1973, p. 32), são uma implicação e uma relação diretas, ainda que generalizações altamente convincentes das relações. Por serem mais gerais do que funções, elas permitem que dependências entre variáveis sejam capturadas sem necessariamente pertencerem a nenhuma caracterização direcional específica dessas variáveis.

Zadeh (2005, p. 4) forneceu uma classificação das diferentes abordagens relacionadas à lógica fuzzy. O ponto de vista preferido de Zadeh é o lingüístico. Tal abordagem é próxima do comportamento humano e permite a melhor forma de aplicação de sistemas inteligentes. A consideração principal é que, quando os dados de observação são nebulosos e as variáveis têm algumas formalidades nebulosas, mas lingüisticamente ou numericamente as definimos, podem ser investigadas algumas abordagens diferentes, tais como:

1. a possibilística;

2. a probabilística e

3. a verídica.

Toda abordagem, expressa de forma lingüística, é numericamente traduzida por:

1. Possibilística e realista: análise estatística descritiva. Essa é a forma de traduzir as palavras em variáveis de freqüência. A diferença entre probabilística e a verídica é que, na possibilística, algumas disjunções são usadas e, na probabilística, não; a abordagem verídica é um caso específico da probabilística;

2. Probabilística: nesse caso, a variância é usada no domínio da função implicativa.

Da mesma forma que no tratamento das variáveis binárias, as variáveis modais freqüências, mais recentemente variável-intervalo, são acrescentadas.

Em relação à classificação das várias abordagens relacionadas à lógica fuzzy de Zadeh (possibilística, probabilística e verídica), a implicação, segundo Gras et al. 
(1997, p. 412) é apresentada como uma nova abordagem, com suas próprias características. A noção de implicação estatística é baseada na comparação estatística entre a inclusão de conjuntos observados em uma população e outra que teria conjuntos comparáveis, mas, escolhidos casualmente na mesma população. Tal abordagem relaciona-se, em particular, com variáveis-intervalos. De acordo com Spagnolo e Gras (2004, p.103) é apropriada para representar implicações fuzzy.

Essa nova perspectiva epistemológica produz interessantes perspectivas de aplicação. A implicação de variáveis de intervalo de Gras não é nem completamente descritiva nem completamente inferencial. Está-se na presença de uma nova abordagem epistemológica para implicação fuzzy. A implicação de Gras implica uma semântica mais rica quando é experimentalmente comparada com outras implicações clássicas, tais como as de Kleene, Reichenbach e Lukasiewicz.

A variedade na natureza das aplicações levou Gras et al. (1997, p. 415) a considerar outros tipos de variáveis: as variáveis modais ordinais (quantificação de níveis de aderência e de satisfação) e a variável de freqüência (número de tantas repetições variáveis por assunto, por exemplo), cujos valores são normatizados em [0,1].

\subsection{5 - Operador de Implicação}

A construção de relações (implicações) conforme Couturier e Fioleau (2000, p. 18), na lógica fuzzy, requer que todas as variáveis usadas estejam contidas no intervalo $[0,1]$ para que se possam representar todas as situações classificadas do 0 (falso) a 1 (verdadeiro). Confrontado com dados brutos, o especialista precisa primeiramente resolver o problema de como transformar ou codificar os dados, antes de escolher uma família de operadores nebulosos para medir a implicação entre critérios.

Considerem-se duas variáveis codificadas: $\mathbf{X}$ e $\mathbf{Y}$. Segundo o teorema de Klir e Yuan (1995, p. 49): "Deixe-se F ser a função definida no intervalo [0, 1] e verificando as seguintes propriedades: $F(0)=0$; F é contínuo e estritamente crescente".

Pode-se, então, definir os operadores de negação e implicação: não $(x)=F[1-F(x)]$; $\operatorname{imp}(x, y)=\inf \{1, F[F(1)-F(x)+F(y)]\}$ (implicação de Lukasiewicz). 
Tomando-se $F(x)=x$ como um caso especial, esses operadores se tornam, conforme Couturier (2000, p. 20):

não $(x)=1-x\left(\right.$ ou $\left.x^{\prime}\right) ; \operatorname{imp}(x, y)=\inf (1,1-x+y)=\{1$ or, if $x>y$, is $1-x+y\}[15]$.

A tabela a seguir, apresenta alguns dos principais operadores de implicações encontrados na literatura.

Tabela 9 - Principais Operadores de Implicação

\begin{tabular}{|l|l|}
\hline Implicação & Nome \\
\hline $\max (1-\mathrm{x}, \mathrm{y})$ & Kleene \\
\hline $\min (1-\mathrm{x}+\mathrm{x} \cdot \mathrm{y}, 1)$ & Reichenbach \\
\hline $\min (1-\mathrm{x}+\mathrm{y}, 1)$ & Lukasiewicz \\
\hline $\begin{array}{l}1, \text { se } x \leq y \\
\text { se não, } \mathrm{y}\end{array}$ & Gödel \\
\hline $\min (\mathrm{x}, \mathrm{y})$ & Mandani \\
\hline$x \cdot y$ & Larsen \\
\hline
\end{tabular}

\section{Fonte: Elaborada pelo Autor}

Nesse trabalho, somente as implicações de Kleene, Reinchenbach e Lukasiewicz serão usadas.

Por outro lado, quando se analisa uma relação (implicação) entre duas variáveis é importante determinar a região de rejeição dessa relação. Tal fato é crucial para se determinar a implicação de GRAS. A figura seguir, indica essa região. 
Figura 11 - Região de rejeição de três tipos (baixo, médio e alto)

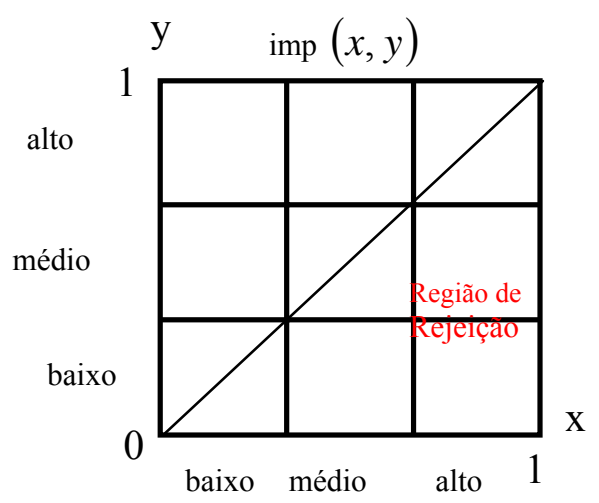

A partir dessa figura, no contexto desse tipo de implicação (semântica da implicação), considera-se que a medida de implicação (imp (x, y)) é igual ou próxima a 1:

1. se o valor de $x$ é fraco, o valor de y pode ser qualquer valor;

2. se o valor de $\mathrm{x}$ é médio, o valor de y só pode ser médio ou forte;

3. se o valor de $\mathrm{x}$ é forte, o valor de y é sempre forte.

Uma forma equivalente de estabelecer isso seria dizer que um valor de y fraco não pode ser obtido por um valor médio ou forte de $\mathrm{x}$.

De acordo com Couturier e Fioleau (2000) [15], a medida da força de uma implicação e.g. imp $(x, y)$, baseada em uma amostragem $[(x 1, y 1),(x n, y n)]$ é:

$\mathrm{m}[\operatorname{imp}(\mathrm{x}, \mathrm{y})]=\frac{\operatorname{card} \mathrm{D}}{\mathrm{n}}$

em que:

card é a cardinalidade;

D denota todos os pares (xi, yi) na região de aceitação. 
A validação, uma espécie de $p$-value pode ser feita usando o teste $p$-value sugerido por Gras (1996) [29]. Então, X tem um nível de confiança $1-\alpha$, se e somente se, $\mathrm{X} \geq 1-\alpha$. A medição da relação implicativa depende do número de casos que a cancelam. Logo, a implicação $\mathrm{a} \Rightarrow \mathrm{b}$ tem um nível de confiança 1- $\alpha$, se e somente se, $\mathrm{X} \geq 1-\alpha$.

\subsection{6 - Validação da Implicação}

A validação pode ser realizada usando o teste sugerido por Gras (1996, p. 67), no qual $n$ é o tamanho da amostragem, $\mathrm{n}_{\mathrm{b}}$ é o número de itens na região de aceitação e $\mathrm{n}_{\mathrm{a}}$ é o número de itens na região de não aceitação. A figura a seguir ilustra esse conceito de análise estatística implicativa. A medida da implicação $A \Rightarrow B$, de acordo com Gras (1996, p. 68), é: ou as amostras $X$ e $Y \in U$, escolhidas aleatória e independentemente, e com a mesma cardinalidade de $\mathrm{A}$ e $\mathrm{B} \in \mathrm{U}$; e $\overline{\mathrm{Y}} \mathrm{e} \overline{\mathrm{B}}$, os complementos de $Y$ e $B$, respectivamente, com $n_{b}=n-n_{b}$.

Figura 12 - As regiões de rejeição foram escurecidas (não-implicação de A sobre B)

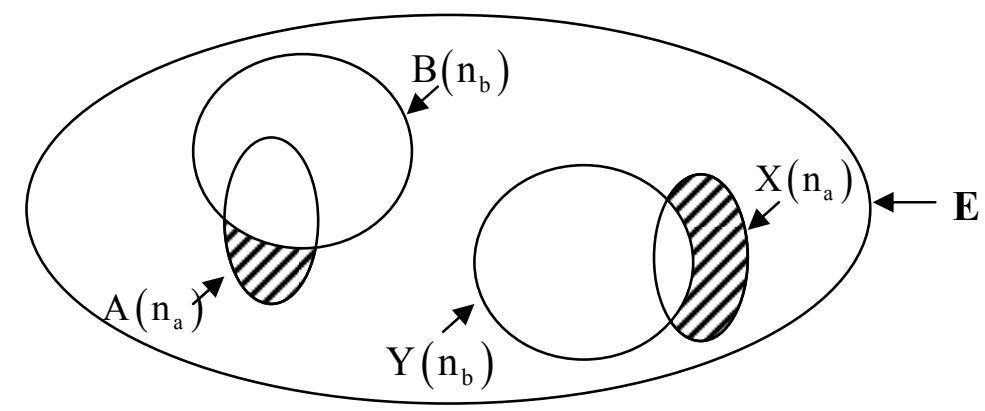

Fonte: Conturier e Fioleau (2000, p. 25) 


\section{CAPÍTULO 5 - RESULTADOS OBTIDOS}

"Pode-se afirmar, em geral, que não há questões esgotadas, senão homens esgotados nas questões".

Ramón Y Cajal (Universidade de Barcelona)

O objetivo principal desta pesquisa foi 0 de verificar se existe impacto da securitização de ativos, nos indicadores financeiros e beta de mercado das empresas, que realizaram operações de securitização no mercado de capitais brasileiro.

Tendo sido encontrado algum impacto, o objetivo secundário foi examinar se esse impacto provocou alguma alteração na classificação do rating de crédito das empresas que realizaram a securitização de ativos.

Para atingir esses objetivos são utilizadas as técnicas regressivas, correlações linear de Pearson e linear/não linear de Spearman e implicações fuzzy nas análises dos dados. Busca-se identificar relações (intensidade e sinal) entre as variáveis analisadas que representam a lucratividade (econômica e financeira) e os riscos (beta de mercado e beta alavancado). Este capítulo foi organizado como segue. $\mathrm{Na}$ Seção 5.2 apresenta-se a análise de regressão. A análise das correlações é realizada na Seção 5.3. Na Seção 5.4 estimam-se as implicações fuzzy.

As próximas seções indicam os resultados obtidos e respondem às hipóteses deste trabalho.

\section{1 - Cálculos dos Indicadores Financeiros Utilizando-se o Balanço Sem e Com a Securitização de Ativos}

Os resultados, a seguir, estabelecem somente as relações específicas entre dois critérios para a análise do balanço, com e sem a securitização de ativos. 
Para a análise dos dados considerando o balanço com a securitização, foram coletados os dados dos balanços dos três exercícios fiscais seguintes à realização da securitização. O critério utilizado de três balanços foi estabelecido de acordo com o mesmo prazo médio das securitizações de ativos realizadas no mercado de capitais, ou seja, as operações de securitização das empresas pesquisadas foram realizadas com prazo médio de 3 anos de vencimento. Foi também estabelecido que: para as empresas da amostra que realizaram a securitização no primeiro semestre de um determinado ano, foi utilizado o balanço daquele próprio ano e, consequentemente, os dois seguintes balanços publicados e, nessa situação esses balanços foram considerados com o efeito da securitização. Já para as empresas que realizaram a securitização no segundo semestre, foram utilizados os balanços dos três anos seguintes.

Em relação à análise dos dados dos balanços sem a securitização, foram utilizados os balanços dos três anos anteriores ao ano da realização da securitização, mantendo-se o mesmo critério demonstrado anteriormente, ou seja, quando a securitização foi realizada no primeiro semestre, foi utilizado o balanço do ano anterior e, quando a securitização foi realizada no segundo semestre, foi utilizado o balanço do próprio ano do início da securitização.

\section{2 - Análise de Regressão}

A partir da análise de regressão, também pode ser possível verificar a existência de relações entre duas variáveis. A equação (4.46) a seguir é utilizada para se implementar as regressões que irão investigar estas relações.

$Y_{i}=a_{i}+b_{i} x_{i}+\varepsilon_{i}$

em que:

$y=$ variável dependente (beta, rentabilidade etc) i no instante $t$;

$a_{i}=$ coeficiente de interseção i no instante $t$;

$x_{i}=$ variável independente $(G A F, G A O$ e GAT) i no instante $t$; 
$b_{i}=$ coeficiente de variação que sinaliza a existência ou não da relação;

$\varepsilon_{\mathrm{i}}=$ termo de erro da regressão, assumindo que se trata de um modelo determinista.

Nessa equação, será utilizado, por exemplo, o beta como sendo a variável dependente $y$, e a alavancagem (GAF) como variável explicativa $x$. São implementadas regressões simples para cada variável.

Por definição, o coeficiente de explicação $R^{2}$ explica a variabilidade do modelo encontrado, ou seja, o quanto o modelo de regressão está explicando o modelo linear encontrado.

Sendo SQR a soma do quadrado da regressão e SQT a soma de quadrado total, tem-se:

$R^{2}=\frac{S Q R}{S Q T}, 0 \leq R^{2} \leq 1$

em que:

$S Q R=\sum_{i=1}^{n}\left(Y_{i}-\bar{Y}\right)^{2} \quad e \quad S Q T=\sum_{i=1}^{n}\left(\hat{Y}_{i}-\bar{Y}\right)^{2}$

$Y_{i}$ :estimado e $\hat{Y}_{i}$ :observado

$\bar{Y}:$ média

Já o coeficiente de explicação $R^{2}$ ajustado capta a influência dos graus de liberdade na qualidade da regressão, ou seja, considera o número de variáveis preditoras ou independentes do modelo. Logo, o $\mathrm{R}^{2}$ ajustado é adequado para comparar modelos com diferentes quantidades de variáveis preditoras. A fórmula é dada por:

A correlação de Pearson é a raiz quadrada do coeficiente de explicação $R^{2}$, sendo de caráter eminentemente linear, não captando as possíveis não linearidades existentes nos dados (NETER et al. 1996, p. 232). Já o coeficiente de explicação 
$\mathrm{R}^{2}$ ajustado capta a influência dos graus de liberdade na qualidade da regressão. Logo, o $\mathrm{R}^{2}$ ajustado foi criado para captar esses efeitos dos graus de liberdade do modelo regressivo e pode ser estimado por:

$$
R_{\text {ajustado }}^{2}=1-\left(1-\mathrm{R}^{2}\right) \frac{(\mathrm{n}-1)}{(\mathrm{n}-\mathrm{k}-1)}
$$

em que:

- $\mathrm{n}$ é o número de amostras e

- $\mathrm{k}$ é o número de graus de liberdade

Com o objetivo de minerar relações, as regressões foram estimadas também com a normalização das variáveis (dependentes e independentes) e também foram forçadas a passar pela origem. As transformações são comuns na área de regressões, como as de Box-Cox, bem como da extração da raiz da variável independente $\left(x^{\prime}=\sqrt{x}\right)($ NETER, 1996). Posteriormente, o valor original da variável pode ser recuperado por meio de uma anti-transformação. Esta transformação pode atenuar alguma não linearidade. Dessa forma, uma função com característica exponencial pode ter esta característica atenuada ao se aplicar uma transformação do tipo $x^{\prime}=\sqrt{x}$. No caso deste trabalho, optou-se pela normalização entre $-1 \mathrm{e}+1$ para tentar captar possíveis efeitos de escalas e para que os valores ficassem próximos dos nebulosos que serão utilizados nas análises via lógica nebulosa (fuzzy).

Estabeleceu-se também na análise dos dados a passagem forçada pela origem, que por sua vez, foi utiliza para minerar alguma possível relação, principalmente entre as variáveis normalizadas. Entretanto, as análises a partir deste tipo de resultado devem ser realizadas com bastante cuidado. Assim, os resíduos devem ser analisados criteriosamente e possivelmente a soma deles não será zero porque a curva verdadeira não passa exatamente pela origem. Outra questão é que podem ocorrer valores negativos de $\mathrm{R}^{2}$ ajustado e sem sentidos (negativos). Entretanto, alguns pacotes estatísticos conseguem obter valores sempre positivos, mas que não 
possibilitam uma interpretação consistente. Optou-se por utilizar esta técnica, mesmo sabendo que a mesma apresenta possíveis limitações porque a mesma não é utilizada isoladamente, mas em conjunto com outros tipos de análises.

\subsection{1 - Resultados das Regressões Lineares}

O primeiro indicador definido foi o beta de mercado, conforme demonstrado na seção 4.9. A partir dos cálculos dos betas observados, foram realizadas as regressões entre os betas de mercado e os três graus de alavancagem, para testar a primeira hipótese desta pesquisa, ou seja, existem relações entre a alavancagem (financeira, operacional e total) e o beta (risco). Com o objetivo de minerar relações, as regressões foram testadas sem e com a normalização das variáveis, conforme demonstrado nas tabelas (10 até 13).

\subsection{2 - Relação entre os Graus de Alavancagem (GAT,GAF e GAO) e o Beta}

A tabela a seguir, apresenta os coeficientes de associações encontrados para as variáveis via regressão passando pelo zero, sem securitização, sem e com normalização.

Tabela 10 - Regressões dos betas em relação aos três graus de alavancagem (GAT, GAF e GAO), passando pela origem: sem securitização

\begin{tabular}{|c|c|c|c|c|c|c|}
\hline \multirow[t]{2}{*}{ Sem Norm } & & \multicolumn{2}{|c|}{ Beta } & \multicolumn{2}{|c|}{ DesvPad } & \multirow[t]{2}{*}{ R2_adj } \\
\hline & & $\mathbf{a}$ & b & $a$ & $\mathrm{~b}$ & \\
\hline InEndTot & Beta & 0 & 0.0365 & 0 & 0.0040 & -0.128 \\
\hline GAT & Beta & 0 & 0.0138 & 0 & 0.0014 & 0.0044 \\
\hline GAF & Beta & 0 & 0.0039 & 0 & 0.0078 & -1.0 \\
\hline GAO & Beta & 0 & 0.1143 & 0 & 0.0401 & -1.0 \\
\hline
\end{tabular}

\begin{tabular}{|c|c|c|c|c|c|c|}
\hline \multirow[t]{2}{*}{ Com Norm } & & \multicolumn{2}{|c|}{ Beta } & \multicolumn{2}{|c|}{ DesvPad } & \multirow[t]{2}{*}{ R2_adj } \\
\hline & & $\mathrm{a}$ & $b$ & $a$ & $\mathrm{~b}$ & \\
\hline InEndTot & Beta & 0 & 0.4531 & 0 & 0.0501 & -0.128 \\
\hline GAT & Beta & 0 & 0.7579 & 0 & 0.0744 & 0.0044 \\
\hline GAF & Beta & 0 & 0.7047 & 0 & 0.1823 & -0.899 \\
\hline GAO & Beta & 0 & 0.8868 & 0 & 0.3114 & -1.0 \\
\hline
\end{tabular}

Fonte: Elaborada pelo Autor 
A partir das regressões dessa tabela, sem normalização, não se pode concluir sobre a existência de alguma relação entre as variáveis.

Entretanto, observa-se na tabela com normalização, alguns valores interessantes de coeficientes de associação apareceram nas regressões, como: o valor de $b$ para o GAF é $(0,7047)$, mas o $R^{2}$ ajustado é negativo e o desvio-padrão é relativamente baixo. Predominou a presença significativa de coeficientes no intervalo de 0,5 e 1 , com valores indicando relações entre as variáveis, mas somente os indicadores GAF e GAO apresentaram desvio-padrão aceitáveis. A normalização permitiu a localização destas relações.

A tabela a seguir, apresenta os coeficientes de associações encontrados para as variáveis via regressão passando pelo zero e com valores securitizados.

Tabela 11 - Regressões dos betas em relação aos três graus de alavancagem (GAT, GAF e GAO), passando pela origem: com securitização

\begin{tabular}{|l|l|l|l|l|l|l|}
\hline \multirow{2}{*}{ Sem Norm } & \multirow{2}{*}{} & \multicolumn{2}{|c|}{ Beta } & \multicolumn{2}{c|}{ DesvPad } & \multirow{2}{*}{ R2_adj } \\
\cline { 3 - 7 } & & $\mathrm{a}$ & $\mathrm{b}$ & $\mathrm{a}$ & $\mathrm{b}$ & \\
\hline InEndTot_sec & Beta & 0 & 0.0365 & 0 & 0.0040 & -0.128 \\
\hline GAT_sec & Beta & 0 & 0.0138 & 0 & 0.0014 & 0.0044 \\
\hline GAF_sec & Beta & 0 & 0.1253 & 0 & 0.0324 & -0.899 \\
\hline GAO_sec & Beta & 0 & 0.2481 & 0 & 0.0572 & -1.0 \\
\hline
\end{tabular}

\begin{tabular}{|c|c|c|c|c|c|c|}
\hline \multirow[t]{2}{*}{ Com Norm } & & \multicolumn{2}{|c|}{ Beta } & \multicolumn{2}{|c|}{ DesvPad } & \multirow[t]{2}{*}{ R2_adj } \\
\hline & & $\mathrm{a}$ & $\mathrm{b}$ & $\mathrm{a}$ & $\mathrm{b}$ & \\
\hline InEndTot_sec & Beta & 0 & 0.4728 & 0 & 0.0586 & -0.179 \\
\hline GAT_sec & Beta & 0 & 0.8314 & 0 & 0.0824 & 0.0048 \\
\hline GAF sec & Beta & 0 & 0.7985 & 0 & 0.0947 & -0.925 \\
\hline GAO_sec & Beta & 0 & 0.9263 & 0 & 0.2596 & -1.0 \\
\hline
\end{tabular}

Fonte: Elaborada pelo Autor

Conforme essa tabela, sem normalização, somente os indicadores GAF e GAO apresentaram desvio-padrão $(0.0324)$ e $(0,572)$ respectivamente, aceitáveis, porém o $b$ que indica a associação das relações entre as variáveis, são muito baixos. Revelando, portanto, a baixa associação entre as variáveis. 
Nessa mesma tabela com normalização, os mesmos indicadores GAF e GAO destacaram-se e apresentaram desvio-padrão aceitáveis, mas com o $R^{2}$ ajustados baixos. A normalização permitiu a localização de relações mais intensas. Observa-se que a reta de regressão foi forçada a passar pela origem.

A tabela a seguir, apresenta os coeficientes de associações encontrados para as variáveis das regressões dos betas em relação ao índice de endividamento e aos três graus de alavancagem (GAO, GAF e GAT) não forçadas a passar pela origem e sem securitização.

Tabela 12 - Regressões dos betas em relação aos três graus de alavancagem (GAT, GAF e GAO), não passando pela origem: sem securitização

\begin{tabular}{|l|l|l|c|c|c|l|}
\hline \multirow{2}{*}{$\begin{array}{l}\text { Sem Norm } \\
\text { Const }=1\end{array}$} & & \multicolumn{2}{|c|}{ Beta } & \multicolumn{2}{c|}{ DesvPad } & \multirow{2}{*}{ R2_adj } \\
\cline { 3 - 6 } & & $\mathrm{a}$ & $\mathrm{b}$ & $\mathrm{a}$ & $\mathrm{b}$ & \\
\hline InEndTot & Beta & 1.2625 & 0.0008 & 0.3786 & 0.0065 & 0.0 \\
\hline GAT & Beta & 1.0167 & 0.0016 & 0.1778 & 0.0007 & 0.0603 \\
\hline GAF & Beta & 1.3483 & -0.0076 & 0.1303 & 0.0053 & 0.0246 \\
\hline GAO & Beta & 1.3105 & -0.0011 & 0.1409 & 0.0307 & 0.0 \\
\hline
\end{tabular}

\begin{tabular}{|l|l|l|l|l|c|l|}
\hline \multirow{2}{*}{$\begin{array}{l}\text { Com Norm } \\
\text { Const }=1\end{array}$} & \multirow{2}{*}{} & \multicolumn{2}{|c|}{ Beta } & \multicolumn{2}{c|}{ DesvPad } & \multirow{2}{*}{ R2_adj } \\
\cline { 3 - 6 } & & $\mathrm{a}$ & $\mathrm{b}$ & $\mathrm{a}$ & $\mathrm{b}$ & \\
\hline InEndTot & Beta & 0.252 & 0.014 & 0.0757 & 0.1105 & 0.0002 \\
\hline GAT & Beta & 0.2033 & 0.4097 & 0.0356 & 0.1776 & 0.0603 \\
\hline GAF & Beta & 0.2697 & -0.268 & 0.0261 & 0.1855 & 0.0246 \\
\hline GAO & Beta & 0.2621 & -0.008 & 0.0282 & 0.2383 & 0.0001 \\
\hline
\end{tabular}

Fonte: Elaborada pelo Autor

A partir das regressões dessa tabela sem normalização, não se pode concluir sobre a existência de alguma relação entre as variáveis. Entretanto, já é possível observar os sinais das relações (dos b's do beta de mercado). Neste caso, os resultados indicam baixa associação entre as alavancagens e os betas de mercado das ações.

Os resultados com normalização, não indicam relação entre as variáveis, os $\mathrm{R}^{2}$ ajustados permanecem muito baixos, logo não se pode concluir que estes 
coeficientes indiquem alguma associação, apesar de que o coeficiente entre o beta e o GAT seja relativamente médio $(0,4097)$.

Assim, em resposta à primeira hipótese da pesquisa, pode-se afirmar a possibilidade de baixa relação estatisticamente significante apenas entre o beta de mercado e os graus de alavancagem financeira (GAF) e operacional (GAO).

A tabela a seguir, apresenta os coeficientes de associações encontrados para as variáveis com valores securitizados via regressão não forçada a passar pela origem.

Tabela 13 - Regressões dos betas em relação aos três graus de alavancagem (GAT, GAF e GAO), não passando pela origem: com securitização

\begin{tabular}{|l|l|c|c|c|c|l|}
\hline \multirow{2}{*}{$\begin{array}{l}\text { Sem Norm } \\
\text { Const }=1\end{array}$} & & \multicolumn{2}{|c|}{ Beta } & \multicolumn{2}{c|}{ DesvPad } & \multirow{2}{*}{ R2_adj } \\
\cline { 3 - 6 } & & $\mathrm{a}$ & $\mathrm{b}$ & $\mathrm{a}$ & $\mathrm{b}$ & \\
\hline InEndTot_sec & Beta & 0.9792 & 0.0110 & 0.2742 & 0.0081 & 0.0217 \\
\hline GAT_sec & Beta & 0.7726 & 0.0082 & 0.1554 & 0.0016 & 0.2329 \\
\hline GAF_sec & Beta & 1.2673 & 0.0159 & 0.1460 & 0.0267 & 0.0042 \\
\hline GAO_sec & Beta & 1.3105 & -0.001 & 0.1409 & 0.0307 & 0.0 \\
\hline
\end{tabular}

\begin{tabular}{|l|l|c|c|c|c|l|}
\hline \multirow{2}{*}{$\begin{array}{l}\text { Com Norm } \\
\text { Const = 1 }\end{array}$} & & \multicolumn{2}{|c|}{ Beta } & \multicolumn{2}{c|}{ DesvPad } & \multirow{2}{*}{ R2_adj } \\
\cline { 3 - 6 } & & $\mathrm{a}$ & $\mathrm{b}$ & $\mathrm{a}$ & $\mathrm{b}$ & \\
\hline InEndTot_sec & Beta & 0.1958 & 0.1360 & 0.0548 & 0.1003 & 0.0217 \\
\hline GAT_sec & Beta & 0.1545 & 0.4510 & 0.0311 & 0.0898 & 0.2329 \\
\hline GAF_sec & Beta & 0.2535 & 0.0892 & 0.0292 & 0.1499 & 0.0042 \\
\hline GAO_sec & Beta & 0.2983 & -0.027 & 0.0367 & 0.1749 & 0.0038 \\
\hline
\end{tabular}

Fonte: Elaborada pelo Autor

Conforme os resultados apresentados nessa tabela, sem normalização, indicam que os $\mathrm{R}^{2}$ ajustados estão muito baixos, logo não se pode concluir que estes coeficientes indiquem alguma relação. Já nessa mesma tabela com normalização observa-se uma relação com grau de associação médio (0.4510) para o GAT, porém o $\mathrm{R}^{2}$ ajustado observado é muito baixo. 
Assim, em resposta à primeira hipótese da pesquisa, não se pode afirmar que existe associação entre as variáveis não securitizadas e securitizadas e o beta de mercado.

Potanto, em resposta à quarta hipótese da pesquisa, se existe impacto da securitização de recebíveis entre os graus de alavancagem e o beta de mercado, pode-se afirmar somente que, existe a possibilidade de uma baixa relação entre as alavancagens (GAT, GAF e GAO) e o beta de mercado das ações.

\subsection{3 - Relação entre os graus de alavancagem (GAT, GAF e GAO) e o Beta Alavancado}

A segunda hipótese de pesquisa deste trabalho, diz respeito à relação entre a os três graus de alavancagem (GAT, GAF, e GAO) da empresa e o beta alavancado. Logo, o resultado das regressões, de acordo com as tabelas (14 até 17) a seguir, foi testado utilizando-se o beta alavancado.

Tabela 14 - Regressões dos betas alavancados em relação aos três graus de alavancagem (GAT, GAF e GAO), passando pela origem: sem securitização

\begin{tabular}{|c|c|c|c|c|c|c|}
\hline \multirow{2}{*}{ Sem Norm } & \multirow{2}{*}{} & \multicolumn{2}{|c|}{ Beta Alavanc } & \multicolumn{2}{c|}{ DesvPad } & \multirow{2}{*}{ R2_adj } \\
\cline { 3 - 6 } & & $\mathrm{a}$ & $\mathrm{b}$ & $\mathrm{a}$ & $\mathrm{b}$ & \\
\hline InEndTot & Beta_a & 0 & 0.0129 & 0 & 0.0008 & -0.268 \\
\hline GAT & Beta_a & 0 & 0.0025 & 0 & 0.0004 & -1 \\
\hline GAF & Beta_a & 0 & 0.0064 & 0 & 0.0038 & -1 \\
\hline GAO & Beta_a & 0 & 0.0609 & 0 & 0.0197 & -1 \\
\hline
\end{tabular}

\begin{tabular}{|c|c|c|c|c|c|c|}
\hline \multirow{2}{*}{ Com Norm } & \multirow{2}{*}{} & \multicolumn{2}{|c|}{ Beta Alavanc } & \multicolumn{2}{c|}{ DesvPad } & \multirow{2}{*}{ R2_adj } \\
\cline { 3 - 6 } & & $\mathrm{a}$ & $\mathrm{b}$ & $\mathrm{a}$ & $\mathrm{b}$ & \\
\hline InEndTot & Beta_a & 0 & 0.5985 & 0 & 0.0409 & -0.268 \\
\hline GAT & Beta_a & 0 & 1.0685 & 0 & 0.1522 & -1 \\
\hline GAF & Beta_a & 0 & 0.6147 & 0 & 0.3637 & -1 \\
\hline GAO & Beta_a & 0 & 1.2908 & 0 & 0.4177 & -1 \\
\hline
\end{tabular}

Fonte: Elaborada pelo Autor

Os resultados dessa tabela, sem normalização, indicam associação com baixa intensidade entre GAT, GAF e GAO e os betas alavancados. Os $\mathrm{R}^{2}$ ajustados são baixos (sem sentidos) e a inclinação da regressão (b's) tem sinal positivo. 
Nessa mesma tabela com normalização, o valor de associação entre o indice de endividamento total e o beta alavancado foi sempre maior que 0,5985 , com desvio padrão baixo para o índice, e a inclinação da regressão (b's) com sinal positivo. Mas o $\mathrm{R}^{2}$ ajustado é baixo para todas as variáveis.

A tabela a seguir, apresenta os coeficientes de associações encontrados para as regressões dos betas alavancados em relação aos três graus de alavancagem (GAT, GAF e GAO) forçadas a passar pela origem e sem securitização.

Tabela 15 - Regressões dos betas alavancados em relação aos três graus de alavancagem (GAT, GAF e GAO), não passando pela origem: sem securitização

\begin{tabular}{|l|l|l|c|c|c|l|}
\hline \multirow{2}{*}{$\begin{array}{l}\text { Sem Norm } \\
\text { Const }=1\end{array}$} & & \multicolumn{2}{|c|}{ Beta Alavanc } & \multicolumn{2}{c|}{ DesvPad } & \multirow{2}{*}{ R2_adj } \\
\cline { 3 - 6 } & & $\mathrm{a}$ & $\mathrm{b}$ & $\mathrm{a}$ & $\mathrm{b}$ & \\
\hline InEndTot & Beta_a & 0.6137 & 0.0030 & 0.1339 & 0.0023 & 0.0242 \\
\hline GAT & Beta_a & 0.8775 & -0.001 & 0.0715 & 0.0003 & 0.0420 \\
\hline GAF & Beta_a & 0.7798 & 0.0000 & 0.0469 & 0.0017 & 0 \\
\hline GAO & Beta_a & 0.7808 & -0.001 & 0.0497 & 0.0100 & 0 \\
\hline
\end{tabular}

\begin{tabular}{|l|l|c|c|c|c|l|}
\hline \multirow{2}{*}{$\begin{array}{l}\text { Com Norm } \\
\text { Const }=1\end{array}$} & & \multicolumn{2}{|c|}{ Beta Alavanc } & \multicolumn{2}{c|}{ DesvPad } & \multirow{2}{*}{ R2_adj } \\
\cline { 3 - 6 } & & $\mathrm{a}$ & $\mathrm{b}$ & $\mathrm{a}$ & $\mathrm{b}$ & \\
\hline InEndTot & Beta_a & 0.3354 & 0.1401 & 0.0732 & 0.1063 & 0.0136 \\
\hline GAT & Beta_a & 0.4795 & -0.2397 & 0.0391 & 0.1368 & 0.0244 \\
\hline GAF & Beta_a & 0.4261 & 0.0001 & 0.0257 & 0.1677 & 0 \\
\hline GAO & Beta_a & 0.4267 & -0.0103 & 0.0272 & 0.2131 & 0 \\
\hline
\end{tabular}

Fonte: Elaborada pelo Autor

De acordo com essa tabela, sem normalização e com normalização, os resultados são suficientes para afirmar que se verifica a presença de uma relativa associação positiva entre as variáveis, apesar disso $\circ R^{2}$ e $\circ R^{2}$ ajustado indicam baixa significância estatística. Logo, eses resultados indicam que não se pode afirmar que existe a presença de uma associação entre os graus de alavancagem e o beta alavancado. 
A tabela a seguir, apresenta os coeficientes de associações encontrados para as regressões dos betas alavancados em relação aos três graus de alavancagem (GAT, GAF e GAO) forçadas a passar pela origem e com securitização.

Tabela 16 - Regressões dos betas alavancados em relação aos três graus de alavancagem (GAT, GAF e GAO), passando pela origem: com securitização

\begin{tabular}{|l|c|c|c|c|c|c|}
\hline \multirow{2}{*}{ Sem Norm } & \multirow{2}{*}{} & \multicolumn{2}{c|}{ Beta Alavanc } & \multicolumn{2}{c|}{ DesvPad } & \multirow{2}{*}{ R2_adj } \\
\cline { 3 - 6 } & & $\mathrm{a}$ & $\mathrm{b}$ & $\mathrm{a}$ & $\mathrm{b}$ & \\
\hline InEndTot_sec & Beta_a & 0 & 0.0206 & 0 & 0.0016 & -0.533 \\
\hline GAT_sec & Beta_a & 0 & 0.0046 & 0 & 0.0009 & -1 \\
\hline GAF_sec & Beta_a & 0 & 0.0587 & 0 & 0.0164 & -1 \\
\hline GAO_sec & Beta_a & 0 & 0.0825 & 0 & 0.0241 & -1 \\
\hline
\end{tabular}

\begin{tabular}{|l|c|c|c|c|c|c|}
\hline \multirow{2}{*}{ Com Norm } & \multirow{2}{*}{} & \multicolumn{2}{|c|}{ Beta Alavanc } & \multicolumn{2}{c|}{ DesvPad } & \multirow{2}{*}{ R2_adj } \\
\cline { 3 - 6 } & & $\mathrm{a}$ & $\mathrm{b}$ & $\mathrm{a}$ & $\mathrm{b}$ & \\
\hline InEndTot_sec & Beta_a & 0 & 0.5985 & 0 & 0.0409 & -0.268 \\
\hline GAT_sec & Beta_a & 0 & 1.0685 & 0 & 0.1522 & -1 \\
\hline GAF_sec & Beta_a & 0 & 0.6147 & 0 & 0.3637 & -1 \\
\hline GAO_sec & Beta_a & 0 & 1.2908 & 0 & 0.4177 & -1 \\
\hline
\end{tabular}

Fonte: Elaborada pelo Autor

Conforme essa tabela, sem normalização, os resultados indicam que se verifica a presença de uma relação entre os graus de alavancagem e o beta alavancado de baixa intensidade, com inclinações das regressões com sinais positivos, porém os e $\mathrm{R}^{2}$ ajustados são negativos.

Nessa mesma tabela com normalização das variáveis, ilustra que o beta alavancado não tem relação com a securitização, essa indicação decorre principalmente pelos resultados apresentados pelo $\mathrm{R}^{2}$ ajustado. 
A tabela a seguir, apresenta os coeficientes de associações encontrados para as variáveis via regressão não forçadas a passar pela origem, com securitização e com normalização.

Tabela 17 - Regressões dos betas alavancados em relação aos três graus de alavancagem (GAT, GAF e GAO), não passando pela origem: com securitização

\begin{tabular}{|l|l|c|c|c|c|l|}
\hline \multirow{2}{*}{$\begin{array}{l}\text { Sem Norm } \\
\text { Const }=1\end{array}$} & & \multicolumn{2}{|c|}{ Beta Alavanc } & \multicolumn{2}{c|}{ DesvPad } & \multirow{2}{*}{ R2_adj } \\
\cline { 3 - 6 } & & $\mathrm{a}$ & $\mathrm{b}$ & $\mathrm{a}$ & $\mathrm{b}$ & \\
\hline InEndTot_sec & Beta_a & 0.6424 & 0.0044 & 0.1004 & 0.0028 & 0.0324 \\
\hline GAT_sec & Beta_a & 0.8756 & -0.0010 & 0.0597 & 0.0006 & 0.0745 \\
\hline GAF_sec & Beta_a & 0.7924 & -0.0040 & 0.0516 & 0.0089 & 0.0038 \\
\hline GAO_sec & Beta_a & 0.7973 & -0.0005 & 0.0359 & 0.0158 & 0 \\
\hline
\end{tabular}

\begin{tabular}{|l|l|c|c|c|c|l|}
\hline \multirow{2}{*}{$\begin{array}{l}\text { Com Norm } \\
\text { Const }=1\end{array}$} & \multirow{2}{*}{$\mathbf{1}$} & \multicolumn{2}{|c|}{ Beta Alavanc } & \multicolumn{2}{c|}{ DesvPad } & \multirow{2}{*}{ R2_adj } \\
\cline { 3 - 6 } & & $\mathrm{a}$ & $\mathrm{b}$ & $\mathrm{a}$ & $\mathrm{b}$ & \\
\hline InEndTot_sec & Beta_a & 0.3354 & 0.1401 & 0.0732 & 0.1063 & 0.0136 \\
\hline GAT_sec & Beta_a & 0.4795 & -0.239 & 0.0391 & 0.1368 & 0.0244 \\
\hline GAF_sec & Beta_a & 0.4261 & 0.009 & 0.0257 & 0.1677 & 0 \\
\hline GAO_sec & Beta_a & 0.4267 & -0.010 & 0.0272 & 0.2131 & 0 \\
\hline
\end{tabular}

Fonte: Elaborada pelo Autor

Esses resultados são suficientes para afirmar que se verifica a presença de uma relativa associação positiva entre as variáveis, apesar disso os $R^{2}$ ajustados são baixo e portanto, indicam baixa significância estatística.

A segunda hipótese da pesquisa, diz respeito sobre a relação entre o beta alavancado e os três graus de alavancagem (GAT, GAF e GAO), assim, os resultados encontrados conforme a tabela 17 acima com normalização, não são suficientes para afirmar que existe forte associação positiva entre o beta alavancado e os graus de alavancagem (GAT, GAF e GAO). Portanto, esse resultado confirma a segunda hipótese desta pesquisa. 
Os resultados apresentados de acordo com a quarta hipótese desta pesquisa, mostra que o beta alavancado possui elevada siginificância estatística, pelo menos para o período analisado nesta pesquisa e para a amostra dos indicadores financeiros estudados, verifica-se a presença de uma forte associação positiva entre o beta alavancado e os graus de alavancagem (GAT, GAF e GAO) conforme observado na tabela 19 com normalização. Entretanto, os $\mathrm{R}^{2}$ ajustados são baixos e não se pode afirmar que a quarta hipótese desta pesquisa seja verdadeira.

As tabelas a seguir, apresentam os resultados obtidos das regressões, utilizando-se os índices de lucratividade econômica e lucratividade financeira em relação aos três graus de alavancagem (GAT,GAF e GAO), com o objetivo de testar a terceira hipótese desta pesquisa, ou seja, existem relações entre a alavancagem (financeira, operacional e total) e as rentabilidades (economica e financeira). Primeiramente, foi testada a lucratividade econômica, conforme demonstrado nas tabelas (18 a 21).

\subsection{4 - Relação entre os graus de alavancagem (GAT, GAF e GAO) e os índices de lucratividade economico e financeiro}

Tabela 18 - Regressões do índice de lucratividade economica em relação aos três graus de alavancagem (GAT, GAF e GAO), passando pela origem: sem securitização

\begin{tabular}{|l|l|l|c|c|c|c|}
\hline \multirow{2}{*}{ Com Norm } & \multirow{2}{*}{} & \multicolumn{2}{|c|}{ LucEconomic } & \multicolumn{2}{c|}{ DesvPad } & \multirow{2}{*}{ R2_adj } \\
\cline { 3 - 7 } & & $\mathrm{a}$ & $\mathrm{b}$ & $\mathrm{a}$ & $\mathrm{b}$ & \\
\hline InEndTot & Yi_eco & 0 & 0.2000 & 0 & 0.0458 & -0.095 \\
\hline GAT & Yi_eco & 0 & 0.4507 & 0 & 0.1668 & -0.238 \\
\hline GAF & Yi_eco & 0 & 0.1735 & 0 & 0.2471 & -0.339 \\
\hline GAO & Yi_eco & 0 & 0.3932 & 0 & 0.2912 & -0.318 \\
\hline
\end{tabular}

Fonte: Elaborada pelo Autor

Pode-se observar nessa tabela que, a regressão da lucratividade econômica em relação ao GAT, foi de $(0,4507)$ demonstrando média significância estatística e com desvio padrão relativamente baixo $(0,1668)$, porém o $R^{2}$ ajustado também indica baixa correlação entre as variáveis. Observa-se o mesmo para o GAO. 
A tabela a seguir, apresenta os coeficientes de associações encontrados para as regressões das rentabilidades econômicas em relação aos três graus de alavancagem (GAO, GAF e GAT) não passando pela origem e com normalização.

Tabela 19 - Regressões do índice de lucratividade economica em relação aos três graus de alavancagem (GAT, GAF e GAO), não passando pela origem: sem securitização

\begin{tabular}{|l|l|c|c|c|c|l|}
\hline \multirow{2}{*}{$\begin{array}{l}\text { Com Norm } \\
\text { Const }=1\end{array}$} & & \multicolumn{2}{|c|}{ LucEconomic } & \multicolumn{2}{|c|}{ DesvPad } & \multirow{2}{*}{ R2_adj } \\
\cline { 3 - 6 } & & $\mathrm{a}$ & $\mathrm{B}$ & $\mathrm{a}$ & $\mathrm{b}$ & \\
\hline InEndTot & Yi_eco & 0.2773 & -0.180 & 0.0871 & 0.1271 & 0.0237 \\
\hline GAT & Yi_eco & 0.1960 & -0.245 & 0.0423 & 0.2115 & 0.0160 \\
\hline GAF & Yi_eco & 0.1632 & -0.072 & 0.0307 & 0.2184 & 0.0013 \\
\hline GAO & Yi_eco & 0.1700 & -0.187 & 0.2765 & 0.0327 & 0.0055 \\
\hline
\end{tabular}

Fonte: Elaborada pelo Autor

O resultado observado da regressão da rentabilidade econômica em relação ao GAT, com normalização foi semelhante ao sem normalização, mas o coeficiente foi um pouco maior. O desvio padrão ficou um pouco maior e o $\mathrm{R}^{2}$ ajustado diminuiu em termos absolutos. O GAF e GAO apresentaram relações com a rentabilidade econômica e os sinais das relações são positivos.

Esses resultados observados, não são suficientes para afirmar que se verifica a presença de uma forte associação positiva entre estas variáveis.

Assim, como resposta à terceira hipótese desta pesquisa, os resultados das tabelas 18 e 19, são consistentes e suficientes para afirmar que não se verifica a presença de associação positiva entre o índice de lucratividade econômica e os três graus de alavancagem.

A tabela a seguir, apresenta os coeficientes de associações encontrados para as regressões das rentabilidades econômicas em relação aos três graus de alavancagem (GAO, GAF e GAT) forçadas a passar pela origem e com securitização. 
Tabela 20 - Regressões do índice de lucratividade economica em relação aos três graus de alavancagem (GAT, GAF e GAO), passando pela origem: com securitização

\begin{tabular}{|c|c|c|c|c|c|c|}
\hline \multirow{2}{*}{$\begin{array}{l}\text { Com Norm } \\
\text { Const }=1\end{array}$} & & \multicolumn{2}{|c|}{ LucEconomic } & \multicolumn{2}{|c|}{ DesvPad } & \multirow[t]{2}{*}{ R2_ad } \\
\hline & & $\mathrm{a}$ & $\mathrm{b}$ & $\mathrm{a}$ & $\mathrm{b}$ & \\
\hline InEndTot_sec & Yi_eco_se & 0 & 0.2474 & 0 & 0.0410 & -0.303 \\
\hline GAT_se & Yi_eco_se & 0 & 0.3724 & 0 & 0.0662 & -0.356 \\
\hline GAF sec & $\mathrm{Yi}$ eco_se & 0 & 0.4647 & 0 & 0.1283 & -0.617 \\
\hline GAO sec & Yi ecosse & 0 & 0.4917 & 0 & 0.2210 & -0.767 \\
\hline
\end{tabular}

Fonte: Elaborada pelo Autor

O resultado observado da regressão do índice de lucratividade econômica em relação aos graus de alavancagem (GAT, GAF e GAO), indicam média significância estatística, com $\mathrm{R}^{2}$ ajustados negativos. Nesse sentido, os resultados indicam que não se pode afirmar que existe associação estatisticamente significante entre o índice de lucratividade econômica e os graus de alavancagem (GAF e GAO).

A tabela a seguir, apresenta os coeficientes de associações encontrados para as regressões das rentabilidades econômicas em relação aos três graus de alavancagem (GAO, GAF e GAT) não forçadas a passar pela origem e com securitização.

Tabela 21 - Regressões do índice de lucratividade economica em relação aos três graus de alavancagem (GAT, GAF e GAO), não passando pela origem: com securitização

\begin{tabular}{|l|c|c|c|c|c|c|}
\hline \multirow{2}{*}{$\begin{array}{l}\text { Com Norm } \\
\text { Const= 1 }\end{array}$} & & \multicolumn{2}{|c|}{ LucEconomic } & \multicolumn{2}{|c|}{ DesvPad } & \multirow{2}{*}{ R2_adj } \\
\cline { 3 - 6 } & & $\mathrm{a}$ & $\mathrm{B}$ & $\mathrm{a}$ & $\mathrm{b}$ & \\
\hline InEndTot_sec & Yi_eco_se & 0.2201 & -0.108 & 0.0418 & 0.0764 & 0.0239 \\
\hline GAT_sec & Yi_eco_se & 0.1494 & 0.0757 & 0.0269 & 0.0778 & 0.0113 \\
\hline GAF_sec & Yi_eco_se & 0.1605 & 0.0750 & 0.0223 & 0.1142 & 0.0052 \\
\hline GAO_sec & Yi_eco_se & 0.1720 & -0.096 & 0.0215 & 0.1814 & 0.0034 \\
\hline
\end{tabular}

Fonte: Elaborada pelo Autor 
Esses resultados observados, não são suficientes para afirmar que se verifica a presença de uma forte associação positiva entre as variáveis. De certa forma, esse resultado confirma o encontrado na tabela 19, que mostram pouca relação do índice de lucratividade econômica com os graus de alavancagem e mesmo com securitização.

Assim, como resposta à terceira hipótese da pesquisa, ou seja, existe relação entre o índice de lucratividade econômica e os três graus de alavancagem (GAT,GAF e GAO), pode-se afirmar que, não foi encontrada associação significante entre as variáveis testadas, ou seja, correlação entre a lucratividade econômica e os graus de alavancagem (GAT,GAF e GAO) conforme observado nas tabelas 18 e 19 .

Portanto, em resposta à quarta hipótese da pesquisa, não se pode afirmar que, foi encontrada evidências de associação significante entre as variáveis testadas, ou seja, existe correlação entre o índice de lucratividade econômica e os graus de alavancagem (GAF e GAO), considerando-se o efeito da securitização, conforme observado na tabela 20.

Ainda, a terceira hipótese testada desta pesquisa, ou seja, existem relações entre a alavancagem (financeira, operacional e total) e as rentabilidades (economica e financeira). A tabela a seguir, apresenta os coeficientes de associações encontrados para as regressões do índice de lucratividade financeira em relação aos três graus de alavancagem (GAO, GAF e GAT) forçadas a passar pela origem e sem securitização.

Tabela 22 - Regressões dos índices de lucratividade financeira em relação aos três graus de alavancagem (GAT, GAF e GAO), passando pela origem: sem securitização

\begin{tabular}{|l|l|l|c|c|c|c|}
\hline \multirow{2}{*}{ Com Norm } & \multirow{2}{*}{} & \multicolumn{2}{|c|}{ LucFinanc } & \multicolumn{2}{c|}{ DesvPad } & \multirow{2}{*}{ R2_adj } \\
\cline { 3 - 6 } & & $\mathrm{a}$ & $\mathrm{B}$ & $\mathrm{a}$ & $\mathrm{b}$ & \\
\hline InEndTot & Yi_fin & 0 & 0.1172 & 0 & 0.0403 & -0.018 \\
\hline GAT & Yi_fin & 0 & 0.3193 & 0 & 0.1404 & -0.056 \\
\hline GAF & Yi_fin & 0 & 0.1442 & 0 & 0.2057 & -0.116 \\
\hline GAO & Yi_fin & 0 & -0.055 & 0 & 0.2440 & -0.122 \\
\hline
\end{tabular}

Fonte: Elaborada pelo Autor 
O resultado observado, da regressão da rentabilidade financeira em relação aos graus de alavancagem (GAT, GAF e GAO) indicam que esses resultados não são suficientes para afirmar que se verifica a presença de uma forte associação positiva entre as variáveis.

A tabela a seguir, apresenta os coeficientes de associações encontrados para as regressões da rentabilidade financeira em relação aos três graus de alavancagem (GAO, GAF e GAT) não forçadas a passar pela origem e com securitização.

Tabela 23 - Regressões dos índices de lucratividade financeira em relação aos três graus de alavancagem (GAT, GAF e GAO), não passando pela origem: sem securitização

\begin{tabular}{|l|l|c|c|c|c|l|}
\hline \multirow{2}{*}{$\begin{array}{l}\text { Com Norm } \\
\text { Const = 1 }\end{array}$} & & \multicolumn{2}{|c|}{ LucFinanc } & \multicolumn{2}{c|}{ DesvPad } & \multirow{2}{*}{ R2_adj } \\
\cline { 3 - 6 } & & $\mathrm{a}$ & $\mathrm{B}$ & $\mathrm{a}$ & $\mathrm{b}$ & \\
\hline InEndTot & Yi_fin & 0.1008 & -0.021 & 0.0803 & 0.1172 & 0.0 \\
\hline GAT & Yi_fin & 0.0845 & 0.0190 & 0.0389 & 0.1943 & 0.0 \\
\hline GAF & Yi_fin & 0.0868 & 0.0135 & 0.0280 & 0.1992 & 0.0 \\
\hline GAO & Yi_fin & 0.1074 & -0.422 & 0.0294 & 0.2485 & 0.0337 \\
\hline
\end{tabular}

Fonte: Elaborada pelo Autor

Esses resultados observados, não são suficientes para afirmar que se verifica a presença de uma forte associação positiva entre as variáveis. De certa forma, esse resultado confirma o encontrado na tabela 22 , que mostram pouca relação do índice de lucratividade financeira com os graus de alavancagem.

Assim, em resposta à terceira hipótese da pesquisa, pode-se afirmar que, de acordo com os dados da amostra das empresas pesquisadas, não envidenciou-se associação estatisticamente significante entre as variáveis testadas.

A tabela a seguir, apresenta os coeficientes de associações encontrados para as regressões dos índices de lucratividade financeira em relação aos três graus de alavancagem (GAO, GAF e GAT) forçadas a passar pela origem e com securitização. 
Tabela 24 - Regressões dos índices de lucratividade financeira em relação aos três graus de alavancagem (GAT, GAF e GAO), passando pela origem: com securitização

\begin{tabular}{|l|l|l|l|l|l|l|}
\hline \multirow{2}{*}{ Com Norm } & & \multicolumn{2}{|c|}{ LucFinanc } & \multicolumn{2}{c|}{ DesvPad } & \multirow{2}{*}{ R2_adj } \\
\cline { 3 - 6 } & & $\mathrm{a}$ & $\mathrm{b}$ & $\mathrm{a}$ & $\mathrm{b}$ & \\
\hline InEndTot_sec & Yi_fin_se & 0 & 0.3119 & 0 & 0.0439 & -0.133 \\
\hline GAT_sec & Yi fin_se & 0 & 0.6034 & 0 & 0.0580 & 0.2091 \\
\hline GAF_sec & Yi_fin_se & 0 & 0.6162 & 0 & 0.1409 & -0.479 \\
\hline GAO_sec & Yi_fin_se & 0 & 0.6191 & 0 & 0.2484 & -0.694 \\
\hline
\end{tabular}

Fonte: Elaborada pelo Autor

O resultado da regressão do índice de lucratividade financeira em relação aos graus de alavancagem, com securitização apresentou para o GAF médio coeficiente de associação de $(0,6162)$, maior que o observado na regressão sem securitização que foi de $(0,1442)$, mas com $R^{2}$ ajustados baixos e negativos. Em relação ao GAO, obaserva-se também, um médio coeficiente de associação $(0,6191)$, muito maior que o observado na regressão sem securitização $(0,055)$, mas com baixos $\mathrm{R}^{2}$ ajustados.

O resultado da regressão da rentabilidade financeira com securitização em relação ao índice de endividamento de longo prazo apresentou um coeficiente de associação de (0.3119), maior que o observado na regressão sem securitização que foi de $(0,1172)$, com desvio padrão menor que $(0,0439)$ e ainda com $R^{2}$ ajustado considerado baixo. Já os graus de alavancagem (GAT, GAF, GAO) apresentaram coeficientes de associação em torno de $(0,6191)$, mas os $R^{2}$ ajustados não foram satisfatórios. Logo, os resultados não indicam que existe relação entre a lucratividade financeira e os graus de alavancagem (GAF e GAO), com os efeitos da securitzação.

A tabela a seguir, apresenta os coeficientes de associações encontrados para as regressões dos índices de lucratividade financeira em relação aos três graus de alavancagem (GAO, GAF e GAT) não forçadas a passar pela origem e com securitização. 
Tabela 25 - Regressões do índice de lucratividade financeira em relação aos três graus de alavancagem (GAT, GAF e GAO), não passando pela origem: com securitização

\begin{tabular}{|l|l|l|l|l|l|l|}
\hline \multirow{2}{*}{$\begin{array}{l}\text { Com Norm } \\
\text { Const = 1 }\end{array}$} & \multicolumn{2}{|c|}{ LucFinanc } & \multicolumn{2}{c|}{ DesvPad } & \multirow{2}{*}{ R2_adj } \\
\cline { 3 - 6 } & \multicolumn{2}{|c|}{$\mathrm{a}$} & $\mathrm{b}$ & $\mathrm{a}$ & $\mathrm{b}$ & \\
\hline $\begin{array}{l}\text { InEndTot_se } \\
\text { c }\end{array}$ & Yi_fin_se & 0.1634 & 0.0474 & 0.0485 & 0.0886 & 0.0034 \\
\hline GAT_se & Yi fin_se & 0.0813 & 0.4419 & 0.0261 & 0.0756 & 0.2917 \\
\hline GAF_sec & Yi_fin_se & 0.1669 & 0.2110 & 0.0252 & 0.1294 & 0.0310 \\
\hline GAO_sec & Yi_fin_se & 0.1873 & -0.0210 & 0.0247 & 0.2086 & 0.0 \\
\hline
\end{tabular}

Fonte: Elaborada pelo Autor

Esses resultados observados nessa tabela, não são suficientes para afirmar que se verifica a presença de uma forte associação positiva entre as variáveis testadas.

Portanto, em resposta à quarta hipótese da pesquisa, pode-se afirmar que existe possibilidade de associação estatisticamente significante apenas entre os graus de alavancagem financeira (GAF), de alavancagem operacional (GAO) e o índice de lucratividade financeira, quando a empresa utiliza a securitização de recebíveis, mas com $\mathrm{R}^{2}$ ajustado baixo, sinal positivo e com a reta forçada a passar pela origem, conforme indicam os resultados da tabela 25 desta seção.

Outro resultado decorrente desses testes indicam, pelo menos para a amostra de empresas analisada, baixa associação estatística entre o índice de endividamento total (InEndTot), e as variáveis testadas, ou seja, beta e indicadores de lucratividade, tanto sem securitização, quanto após o início da securitização. Porém, foi observada satisfatória associação estatística com o beta alavancado. Demonstrando, a correlação existente entre o endividamento e o risco alavancado. Mas apresentando os $\mathrm{R}^{2}$ ajustados baixos.

\subsection{5 - Resumo das relações encontradas no teste de hipóteses da pesquisa}

Os quadros das regressões a seguir, demonstram um resumo dos resultados estatísticos encontrados nesta pesquisa: 
Quadro 16 - Regressão do Beta em relação ao GAT,GAF e GAO

\begin{tabular}{|l|l|}
\hline \multicolumn{1}{|c|}{ Beta } & \multicolumn{1}{|c|}{ Resultados Sem Securitização } \\
\hline Passando pela origem $(a=0)$ & $\begin{array}{l}\mathrm{R}^{2} \text { ajustado baixo para os graus de } \\
\text { alavancagem. }\end{array}$ \\
\hline Não passando pela origem (const $=1)$ & $\begin{array}{l}\mathrm{R}^{2} \text { ajustado baixo para os graus de } \\
\text { alavancagem. }\end{array}$ \\
\hline
\end{tabular}

\begin{tabular}{|l|l|}
\hline \multicolumn{1}{|c|}{ Beta } & \multicolumn{1}{|c|}{ Resultados Com Securitização } \\
\hline Passando pela origem $(a=0)$ & $\begin{array}{l}\text { Elevada significância estatística para os } \\
\text { graus de alavancagem GAF e GAO, mas } \\
\mathrm{R}^{2} \text { ajustado baixo para os graus de } \\
\text { alavancagem }\end{array}$ \\
\hline Não passando pela origem (const=1) & $\begin{array}{l}\text { Baixa sigificância estatística para os três } \\
\text { graus de alavancagem e com } \mathrm{R}^{2} \\
\text { ajustado baixo. }\end{array}$ \\
\hline
\end{tabular}

Fonte: Elaborado pelo Autor

A primeira hipótese de pesquisa diz respeito à relação entre o beta de mercado e os graus de alavancagem (GAT, GAF e GAO), assim, os resultados das regressões indicam baixa relação entre estas variáveis sem securitização.

Assim, em resposta à quarta hipótese da pesquisa, considerando o efeito da securitização, não se pode afirmar que existe relação entre os graus de alavancagem (GAF e GAO) de uma empresa e o beta de mercado das ações. 
Quadro 17- Regressão do Beta Alavancado em relação ao GAT,GAF e GAO

\begin{tabular}{|c|c|}
\hline Beta alavancado & Resultados Sem Securitização \\
\hline Passando pela origem $(a=0)$ & $\begin{array}{c}\text { Satisfatória relação entre os graus de } \\
\text { alavancagem e o beta alavancado, com } \\
\text { sinal positivo, mas } \mathrm{R}^{2} \text { ajustado baixo } \\
\text { para os graus de alavancagem. }\end{array}$ \\
\hline Não passando pela origem (const=1) & $\begin{array}{c}\text { Sem relação entre os graus de } \\
\text { alavancagem e o beta alavancado e } \mathrm{R}^{2} \\
\text { ajustado baixo para os graus de } \\
\text { alavancagem. }\end{array}$ \\
\hline
\end{tabular}

\begin{tabular}{|c|c|}
\hline Beta alavancado & Resultados Com Securitização \\
\hline Passando pela origem $(a=0)$ & $\begin{array}{c}\text { Elevada relação entre os graus de } \\
\text { alavancagem e o beta alavancado, com } \\
\text { sinal positivo, mas } \mathrm{R}^{2} \text { ajustado baixo } \\
\text { para os graus de alavancagem. }\end{array}$ \\
\hline Não passando pela origem (const=1) & $\begin{array}{c}\text { Sem relação entre os graus de } \\
\text { alavancagem e o beta alavancado e } \mathrm{R}^{2} \\
\text { ajustado baixo para os graus de } \\
\text { alavancagem. }\end{array}$ \\
\end{tabular}

Fonte: Elaborado pelo Autor

A segunda hipótese da pesquisa, diz respeito a relação entre o beta alavancado e os graus de alavancagem (GAT,GAF e GAO), sem securitização, assim, os resultados encontrados não são suficientes para afirmar que existe satisfatória associação entre o beta alavancado e os graus de alavancagem, com sinal positivo. Isso não confirma a segunda hipótese desta pesquisa.

Os resultados utilizados para testar a quarta hipótese desta pesquisa mostram que o beta alavancado possui elevada relação, pelo menos para o período 2000-2005 e para a amostra dos indicadores financeiros estudados e, verifica-se a presença de uma forte associação positiva entre o beta alavancado e os graus de alavancagem (GAT, GAF e GAO), com securitização, mas apresentando os $\mathrm{R}^{2}$ ajustados baixos para os graus de alavancagem. Assim, de acordo com os dados apresentados, não se pode afirmar que a quarta hipótese desta pesquisa é verdadeira. 
Quadro 18 - Regressão do índice de lucratividade econômica em relação aos três graus de alavancagem GAT, GAF e GAO

\begin{tabular}{|l|l|}
\hline \multicolumn{1}{|c|}{ Índice de Lucratividade Economica } & \multicolumn{1}{|c|}{ Resultados Sem Securitização } \\
\hline Passando pela origem $(a=0)$ & $\begin{array}{l}\text { Sem relação entre graus de } \\
\text { alavancagem e a lucratividade } \\
\text { econômica e } \mathrm{R}^{2} \text { ajustado baixo para os } \\
\text { graus de alavancagem. }\end{array}$ \\
\hline Não passando pela origem (const $=1)$ & $\begin{array}{l}\text { Sem relação entre graus de } \\
\text { alavancagem e a lucratividade } \\
\text { econômica e } \mathrm{R}^{2} \text { ajustado baixo para os } \\
\text { graus de alavancagem. }\end{array}$ \\
\hline
\end{tabular}

\begin{tabular}{|l|l|}
\hline \multicolumn{1}{|c|}{ Índice de Lucratividade Economica } & \multicolumn{1}{|c|}{ Resultados Com Securitização } \\
\hline Passando pela origem $(a=0)$ & $\begin{array}{l}\text { Satisfatória relação entre os graus de } \\
\text { alavancagem GAF e GAO o o índice de } \\
\text { lucratividade econômica, mas } \mathrm{R} 2 \\
\text { ajustado baixo para os graus de } \\
\text { alavancagem. }\end{array}$ \\
\hline Não passando pela origem (const $=1)$ & $\begin{array}{l}\text { Sem relação entre graus de } \\
\text { alavancagem e a lucratividade } \\
\text { econômica e } \mathrm{R}^{2} \text { ajustado baixo para os } \\
\text { graus de alavancagem. }\end{array}$ \\
\hline
\end{tabular}

Fonte: Elaborado pelo Autor

Assim, em resposta à terceira hipótese da pesquisa, não foi encontrada associação entre as variáveis testadas, ou seja, a relação entre a lucratividade econômica e os graus de alavancagem, sem securitização.

Em resposta à quarta hipótese da pesquisa, não se pode afirmar que foi encontrada associação entre as variáveis testadas, ou seja, satisfatória relação entre a lucratividade econômica e os graus de alavancagem (GAF e GAO), considerando-se o efeito da securitização. 
Quadro 19 - Regressão do índice de lucratividade financeira em relação aos três graus de alavancagem GAT, GAF e GAO

\begin{tabular}{|l|l|}
\hline \multicolumn{1}{|c|}{ Índice de Lucratividade Financeira } & \multicolumn{2}{|c|}{ Resultados Sem Securitização } \\
\hline Passando pela origem $(a=0)$ & $\begin{array}{l}\text { Sem relação entre os graus de } \\
\text { alavancagem e a lucratividade financeira }\end{array}$ \\
\hline Não passando pela origem (const=1) & $\begin{array}{l}\text { Sem relação entre os graus de } \\
\text { alavancagem e a lucratividade financeira }\end{array}$ \\
\hline
\end{tabular}

\begin{tabular}{|l|l|}
\hline \multicolumn{1}{|c|}{ Índice de Lucratividade Financeira } & \multicolumn{1}{|c|}{ Resultados Com Securitização } \\
\hline Passando pela origem $(a=0)$ & $\begin{array}{l}\text { Satisfatória relação entre os graus de } \\
\text { alavancagem GAF e GAO e o índice de } \\
\text { lucratividade financeira, mas R 2 } \\
\text { ajustado baixo para os graus de } \\
\text { alavancagem. }\end{array}$ \\
\hline Não passando pela origem (const=1) & $\begin{array}{l}\text { Sem relação entre graus de } \\
\text { alavancagem e a lucratividade financeira }\end{array}$ \\
\hline
\end{tabular}

Fonte: Elaborado pelo Autor

Em resposta à terceira hipótese da pesquisa pode-se afirmar que, não foi encontrada associação significante entre as variáveis testadas, considerando-se sem o efeito da securitização.

Assim, em resposta à quarta hipótese da pesquisa, não se pode afirmar que existe satisfatória relação entre os graus de alavancagem (GAF e GAO) e o indicador de rentabilidade financeira, quando é realizada a securitização de recebíveis.

Resumidamente, nas análises das relações por meio da regressão linear, observouse que nenhuma hipótese foi confirmada. Portanto, observa-se que as intensidades dessas relações aumentam geralmente com a securitização e a normalização das variáveis. 


\section{3 - Relação entre os Indicadores Financeiros e a Securitização}

As tabelas 26 e 27 a seguir, demonstram a matriz de correlação de Pearson entre as variáveis analisadas sem os efeitos da securitização, sendo que as variáveis da Tabela 29 foram normalizados. Os indicadores analisados são: beta de mercado, beta alavancado, graus de alavancagem (operacional, financeira e total) e o índice (índice de endividamento total ). Esses índices estão apresentados no Capítulo 4.

Caso seja feita uma regressão múltipla, não haverá problemas de correlações entre variáveis independentes já que não se aproximam da unidade, ficando mais próximos de zero do que de um.

Tabela 26 - Correlações de Pearson sem os efeitos da securitização

\begin{tabular}{|c|c|c|c|c|c|c|c|c|}
\hline & Beta & Beta_a & GAO & GAF & GAT & Índice & Luc_fin & Luc_eco \\
\hline Beta & 1 & $\begin{array}{c}-0.1277 \\
(0.2920)\end{array}$ & $\begin{array}{l}-0.0040 \\
(0.9713)\end{array}$ & $\begin{array}{l}-0.1567 \\
(0.1571)\end{array}$ & $\begin{array}{l}0.2455 \\
(0.0253)\end{array}$ & $\begin{array}{l}0.0141 \\
(0.8990)\end{array}$ & $\begin{array}{c}-0.1365 \\
(0.2185)\end{array}$ & $\begin{array}{l}-0.0098 \\
(0.9299)\end{array}$ \\
\hline Beta_a & & 1 & $\begin{array}{l}-0.0058 \\
(0.9622)\end{array}$ & $\begin{array}{l}0.0001 \\
(0.9993)\end{array}$ & $\begin{array}{l}-0.2050 \\
(0.0887)\end{array}$ & $\begin{array}{l}0.1556 \\
(0.1984)\end{array}$ & $\begin{array}{l}0.0304 \\
(0.8027)\end{array}$ & $\begin{array}{l}0.1091 \\
(0.3685)\end{array}$ \\
\hline GAO & & & 1 & $\begin{array}{l}-0.0156 \\
(0.8888) \\
\end{array}$ & $\begin{array}{l}0.0259 \\
(0.8161)\end{array}$ & $\begin{array}{l}0.0360 \\
(0.7469)\end{array}$ & $\begin{array}{l}-0.1835 \\
(0.0969) \\
\end{array}$ & $\begin{array}{l}-0.0743 \\
(0.5045) \\
\end{array}$ \\
\hline GAF & & & & 1 & $\begin{array}{l}0.0546 \\
(0.6237)\end{array}$ & $\begin{array}{l}0.0483 \\
(0.6646)\end{array}$ & $\begin{array}{l}0.0074 \\
(0.9469)\end{array}$ & $\begin{array}{l}-0.0363 \\
(0.7447)\end{array}$ \\
\hline GAT & & & & & 1 & $\begin{array}{l}0.1168 \\
(0.2930)\end{array}$ & $\begin{array}{l}0.0107 \\
(0.9232)\end{array}$ & $\begin{array}{l}-0.1264 \\
(0.2549)\end{array}$ \\
\hline Índice & & & & & & 1 & $\begin{array}{l}-0.0197 \\
(0.8594)\end{array}$ & $\begin{array}{l}-0.1540 \\
(0.1644)\end{array}$ \\
\hline Luc_fin & & & & & & & 1 & $\begin{array}{l}0.0391 \\
(0.7257)\end{array}$ \\
\hline Luc_eco & & & & & & & & 1 \\
\hline
\end{tabular}

Fonte: Elaborada pelo Autor

Essa tabela indica uma associação somente entre o beta e o GAT, significante a 5\%, com sinal positivo. 
Tabela 27 - Correlações de Pearson sem os efeitos da securitização Normalizada

\begin{tabular}{|c|c|c|c|c|c|c|c|c|}
\hline $\begin{array}{l}\text { Com } \\
\text { Norm }\end{array}$ & Beta & Beta_a & GAO & GAF & GAT & Índice & Luc_fin & Luc_eco \\
\hline Beta & 1 & $\begin{array}{l}-0.1277 \\
(0.2920)\end{array}$ & $\begin{array}{l}-0.0025 \\
(0.9838)\end{array}$ & $\begin{array}{l}-0.1786 \\
(0.1390)\end{array}$ & $\begin{array}{l}0.2455 \\
(0.0253)\end{array}$ & $\begin{array}{l}0.0141 \\
(0.8990)\end{array}$ & $\begin{array}{l}-0.1365 \\
(0.2185)\end{array}$ & $\begin{array}{l}-0.0073 \\
(0.9520)\end{array}$ \\
\hline Beta_a & & 1 & $\begin{array}{l}0.0 \\
(0.9993)\end{array}$ & $\begin{array}{l}-0.0058 \\
(0.9622)\end{array}$ & $\begin{array}{l}0.1556 \\
(0.1984)\end{array}$ & $\begin{array}{l}0.0304 \\
(0.8027)\end{array}$ & $\begin{array}{l}-0.2050 \\
(0.0887)\end{array}$ & $\begin{array}{l}0.1091 \\
(0.3685)\end{array}$ \\
\hline GAO & & & 1 & $\begin{array}{l}-0.0376 \\
(0.6274)\end{array}$ & $\begin{array}{l}0.2247 \\
(0.0032)\end{array}$ & $\begin{array}{l}-0.0270 \\
(0.7256)\end{array}$ & $\begin{array}{l}-0.1043 \\
(0.1725)\end{array}$ & $\begin{array}{l}-0.1784 \\
(0.0194)\end{array}$ \\
\hline GAF & & & & 1 & $\begin{array}{l}0.1437 \\
(0.0573)\end{array}$ & $\begin{array}{l}0.0849 \\
(0.2619)\end{array}$ & $\begin{array}{l}0.1422 \\
(0.0599)\end{array}$ & $\begin{array}{l}0.1229 \\
(0.1040)\end{array}$ \\
\hline GAT & & & & & 1 & $\begin{array}{l}0.0749 \\
(0.3178)\end{array}$ & $\begin{array}{l}-0.0423 \\
(0.5739)\end{array}$ & $\begin{array}{l}-0.1284 \\
(0.0864)\end{array}$ \\
\hline Índice & & & & & & 1 & $\begin{array}{l}0.0329 \\
(0.6624)\end{array}$ & $\begin{array}{l}-0.0861 \\
(0.2508)\end{array}$ \\
\hline Luc_fin & & & & & & & 1 & $\begin{array}{l}0.0770 \\
(0.3047)\end{array}$ \\
\hline Luc_eco & & & & & & & & 1 \\
\hline
\end{tabular}

Fonte: Elaborada pelo Autor

Quase a totalidade das correlações apresenta valores baixos de associações estatisticamente significantes, mas os sinais dos valores podem indicar se a relação é direta ou inversa. As únicas medidas que apresentaram correlações estatisticamente significantes a $5 \% \mathrm{com}$ sinal positivo foram: GAT em relação ao beta; GAO em relação ao GAT e à lucratividade econômica (com sinal negativo).

As tabelas 28 e 29 a seguir apresentam a matriz de correlação entre as variáveis analisadas com os efeitos da securitização de recebíveis. Estes dados também sugerem que, caso seja feita uma regressão múltipla, não haverá problemas de correlações entre variáveis independentes já que não se aproximam da unidade, ficando mais próximos de zero do que de um. 
Tabela 28 - Correlações de Pearson com os efeitos da securitização

\begin{tabular}{|c|c|c|c|c|c|c|c|c|}
\hline Sem Norm & Beta & Beta_a & GAO_sec & GAF_sec & GAT_sec & Índ_sec & Lu_fi_sec & Lu_ec_sec \\
\hline Beta & $\begin{array}{l}1 \\
(0)\end{array}$ & $\begin{array}{l}-0.1277 \\
(0.2920)\end{array}$ & $\begin{array}{l}-0.0040 \\
(0.9713)\end{array}$ & $\begin{array}{l}0.0652 \\
(0.5583)\end{array}$ & $\begin{array}{l}0.4826 \\
(0.0000)\end{array}$ & $\begin{array}{l}0.1473 \\
(0.1840)\end{array}$ & $\begin{array}{l}0.4320 \\
(0.0000)\end{array}$ & $\begin{array}{l}0.2176 \\
(0.0481)\end{array}$ \\
\hline Beta_a & & $\begin{array}{l}1 \\
(0)\end{array}$ & $\begin{array}{l}-0.0058 \\
(0.9622)\end{array}$ & $\begin{array}{l}-0.0620 \\
(0.6103)\end{array}$ & $\begin{array}{l}-0.2729 \\
(0.0223)\end{array}$ & $\begin{array}{l}0.1801 \\
(0.1358)\end{array}$ & $\begin{array}{l}-0.1541 \\
(0.2027)\end{array}$ & $\begin{array}{l}-0.1086 \\
(0.3708)\end{array}$ \\
\hline GAO_sec & & & $\begin{array}{l}1 \\
(0)\end{array}$ & $\begin{array}{l}0.0069 \\
(0.9506)\end{array}$ & $\begin{array}{l}0.0084 \\
(0.9396)\end{array}$ & $\begin{array}{l}0.1740 \\
(0.1158)\end{array}$ & $\begin{array}{l}-0.0110 \\
(0.9212)\end{array}$ & $\begin{array}{l}-0.0580 \\
(0.6028)\end{array}$ \\
\hline GAF_sec & & & & $\begin{array}{l}1 \\
(0)\end{array}$ & $\begin{array}{l}0.2992 \\
(0.0060)\end{array}$ & $\begin{array}{l}0.0522 \\
(0.6395)\end{array}$ & $\begin{array}{l}0.1762 \\
(0.1111)\end{array}$ & $\begin{array}{l}0.0719 \\
(0.5181)\end{array}$ \\
\hline GAT_sec & & & & & $\begin{array}{l}1 \\
(0)\end{array}$ & $\begin{array}{l}0.0885 \\
(0.4263)\end{array}$ & $\begin{array}{l}0.5401 \\
(0.0000)\end{array}$ & $\begin{array}{l}0.1062 \\
(0.3392)\end{array}$ \\
\hline Índice_sec & & & & & & $\begin{array}{l}1 \\
(0)\end{array}$ & $\begin{array}{l}0.0587 \\
(0.5983)\end{array}$ & $\begin{array}{l}-0.1546 \\
(0.1627)\end{array}$ \\
\hline Lu_fin_sec & & & & & & & $\begin{array}{l}1 \\
(0)\end{array}$ & $\begin{array}{l}0.6832 \\
(0.0000)\end{array}$ \\
\hline Lu_eco_sec & & & & & & & & $\begin{array}{l}1 \\
(0)\end{array}$ \\
\hline
\end{tabular}

Fonte: Elaborada pelo Autor

Essa tabela indica que o efeito da securitização faz com que existam mais associações significantes a 5\%, com sinal positivo, ou seja, o beta com o GAT_sec, lucratividade financeira e lucratividade economica, exceto o beta alavancado com o GAT_sec que possui sinal negativo; o GAF_sec e o GAT_sec; o GAT_sec e a lucratividade financeira; a lucratividade financeira e a lucratividade economica.

Tabela 29 - Correlações de Pearson com os efeitos da securitização Normalizada

\begin{tabular}{|c|c|c|c|c|c|c|c|c|}
\hline Com Norm & Beta & Beta_a & GAO_sec & GAF_sec & GAT_sec & Índ_sec & Lu_fi_sec & Lu_ec_sec \\
\hline Beta & 1 & $\begin{array}{l}-0.1277 \\
(0.2920) \\
\end{array}$ & $\begin{array}{l}-0.0040 \\
(0.9713)\end{array}$ & $\begin{array}{l}0.0652 \\
(0.5583)\end{array}$ & $\begin{array}{l}0.4826 \\
(0.0000)\end{array}$ & $\begin{array}{l}0.1473 \\
(0.1840)\end{array}$ & $\begin{array}{l}0.4320 \\
(0.0000)\end{array}$ & $\begin{array}{l}0.2176 \\
(0.0481)\end{array}$ \\
\hline Beta_a & & 1 & $\begin{array}{l}-0.0058 \\
(0.9622) \\
\end{array}$ & $\begin{array}{l}-0.0620 \\
(0.6103)\end{array}$ & $\begin{array}{l}-0.2729 \\
(0.0223) \\
\end{array}$ & $\begin{array}{l}0.1801 \\
(0.1358) \\
\end{array}$ & $\begin{array}{l}-0.1541 \\
(0.2027)\end{array}$ & $\begin{array}{l}-0.1086 \\
(0.3708) \\
\end{array}$ \\
\hline GAO_sec & & & 1 & $\begin{array}{l}0.0069 \\
(0.9506) \\
\end{array}$ & $\begin{array}{l}0.0084 \\
(0.9396) \\
\end{array}$ & $\begin{array}{l}0.1740 \\
(0.1158) \\
\end{array}$ & $\begin{array}{l}-0.0110 \\
(0.9212)\end{array}$ & $\begin{array}{l}-0.0580 \\
(0.6028) \\
\end{array}$ \\
\hline GAF_sec & & & & 1 & $\begin{array}{l}0.2992 \\
(0.0060)\end{array}$ & $\begin{array}{l}0.0522 \\
(0.6395)\end{array}$ & $\begin{array}{l}0.1762 \\
(0.1111)\end{array}$ & $\begin{array}{l}0.0719 \\
(0.5181)\end{array}$ \\
\hline GAT_sec & & & & & 1 & $\begin{array}{l}0.0885 \\
(0.4263) \\
\end{array}$ & $\begin{array}{l}0.5401 \\
(0.0000)\end{array}$ & $\begin{array}{l}0.1062 \\
(0.3392) \\
\end{array}$ \\
\hline Índice_sec & & & & & & 1 & $\begin{array}{l}0.0587 \\
(0.5983)\end{array}$ & $\begin{array}{l}-0.1546 \\
(0.1627)\end{array}$ \\
\hline Lu_fin_sec & & & & & & & 1 & $\begin{array}{l}0.6832 \\
(0.0000)\end{array}$ \\
\hline Lu_eco_sec & & & & & & & & 1 \\
\hline
\end{tabular}

Fonte: Elaborada pelo Autor 
Conforme demonstrado nessa tabela, há uma indicação que os efeitos da securitização e da normalização fazem com que apareçam mais associações existentes significantes a $5 \%$, exceto o beta alavancado com o GAT_sec.. Essas associações são: o beta com o GAT_sec e com o índice de lucratividade financeira; o GAF_sec com o GAT_sec; e o GAT_sec com a lucratividade financeira e lucratividade financeira com a lucratividade financeira.

Os resultados encontrados indicam que: em resposta a primeira hipótese da pesquisa, pode-se afirmar que existe associação estatisticamente significante, entre a alavancagem total e o beta de mercado das empresas.

Como resposta à segunda hipótese da pesquisa pode-se afirmar que existe relação entre o grau de alavancagem total e o beta alavancado, sendo essa relação estatisticamente significante.

Assim em relação a terceira hipótese não foram encontrados resultados que indiquem relação entre os graus de alavancagem e a rentabilidade das empresas.

Constata-se que, os indicadores testados com os efeitos da securitização acarretaram valores de correlações maiores que os indicadores sem o efeito da securitização, isso sendo válido para as três hipóteses.

Logo em relação à quarta hipótese da pesquisa, verificou-se que as três hipóteses, são afetadas significativamente, pelos efeitos da securitização.

Em resumo, das quatro hipóteses analisadas por meio das correlações de Pearson, somente a terceira, que trata da relação entre os graus de alavancagem (GAT, GAF e GAO) e os indicadores de lucratividade, não foi confirmada.

As tabelas a seguir $(30,31,32$ e 33) ilustram os resultados estatísticos das correlações com a utilização do modelo de Spearman, em que as variáveis utilizadas são as mesmas da correlação de Pearson, bem como essas variáveis foram normalisadas e não-normalisadas. Estes dados também sugerem que, caso seja feita uma regressão múltipla, não haverá problemas de correlações entre variáveis independentes já que não se aproximam da unidade, ficando mais próximos de zero do que de um. 
Tabela 30 - Correlações de Spearman sem os efeitos da securitização

\begin{tabular}{|c|c|c|c|c|c|c|c|c|}
\hline & Beta & Beta_a & GAO & GAF & GAT & Índice & Luc fin & Luc_eco \\
\hline Beta & $\begin{array}{l}1 \\
(0)\end{array}$ & $\begin{array}{l}-0.0015 \\
(0.9900)\end{array}$ & $\begin{array}{l}0.0460 \\
(0.6795)\end{array}$ & $\begin{array}{l}-0.1262 \\
(0.2557)\end{array}$ & $\begin{array}{l}0.1764 \\
(0.1107)\end{array}$ & $\begin{array}{l}-0.0463 \\
(0.6778)\end{array}$ & $\begin{array}{l}-0.0464 \\
(0.6767)\end{array}$ & $\begin{array}{l}-0.0206 \\
(0.8531)\end{array}$ \\
\hline Beta_a & & $\begin{array}{l}1 \\
(0)\end{array}$ & $\begin{array}{l}-0.0071 \\
(0.9536)\end{array}$ & $\begin{array}{l}0.0594 \\
(0.6250)\end{array}$ & $\begin{array}{l}-0.1065 \\
(0.3802)\end{array}$ & $\begin{array}{l}0.1654 \\
(0.1712)\end{array}$ & $\begin{array}{l}0.0015 \\
(0.9902)\end{array}$ & $\begin{array}{l}0.1183 \\
(0.3292)\end{array}$ \\
\hline GAO & & & $\begin{array}{l}1 \\
(0)\end{array}$ & $\begin{array}{l}-0.0663 \\
(0.5517)\end{array}$ & $\begin{array}{l}0.3308 \\
(0.0023)\end{array}$ & $\begin{array}{l}-0.0314 \\
(0.7780)\end{array}$ & $\begin{array}{l}-0.1043 \\
(0.1725)\end{array}$ & $\begin{array}{l}-0.1784 \\
(0.0194)\end{array}$ \\
\hline GAF & & & & $\begin{array}{l}1 \\
(0)\end{array}$ & $\begin{array}{l}0.2142 \\
(0.0518)\end{array}$ & $\begin{array}{l}0.1290 \\
(0.2451)\end{array}$ & $\begin{array}{l}0.1918 \\
(0.0824)\end{array}$ & $\begin{array}{l}0.1861 \\
(0.0920)\end{array}$ \\
\hline GAT & & & & & $\begin{array}{l}1 \\
(0)\end{array}$ & $\begin{array}{l}0.0956 \\
(0.3892)\end{array}$ & $\begin{array}{l}-0.0748 \\
(0.5014)\end{array}$ & $\begin{array}{l}-0.2081 \\
(0.0591)\end{array}$ \\
\hline Índice & & & & & & $\begin{array}{l}1 \\
(0)\end{array}$ & $\begin{array}{l}0.0626 \\
(0.5740) \\
\end{array}$ & $\begin{array}{l}-0.1332 \\
(0.2293) \\
\end{array}$ \\
\hline Luc_fin & & & & & & & $\begin{array}{l}1 \\
(0)\end{array}$ & $\begin{array}{l}0.1213 \\
(0.2748)\end{array}$ \\
\hline Luc_eco & & & & & & & & $\begin{array}{l}1 \\
(0)\end{array}$ \\
\hline
\end{tabular}

Fonte: Elaborada pelo Autor

As únicas medidas que apresentaram correlações estatisticamente significantes a 5\% foram: beta em relação ao GAT; beta_a em relação ao índice; GAO em relação ao GAT; GAF em relação ao GAT e à lucratividade financeira e economica. Os sinais são positivos.

A tabela a seguir, apresenta as correlações de Spearman sem os efeitos da securitização e com normalização.

Tabela 31 - Correlações de Spearman sem os efeitos da securitização Normalizada

\begin{tabular}{|c|c|c|c|c|c|c|c|c|}
\hline Com Norm & Beta & Beta_a & GAO & GAF & GAT & Índice & Luc_fin & Luc_eco \\
\hline Beta & $\begin{array}{l}1 \\
(0)\end{array}$ & $\begin{array}{l}-0.0015 \\
(0.990)\end{array}$ & $\begin{array}{c}0.0460 \\
(0.6795)\end{array}$ & $\begin{array}{l}-0.1262 \\
(0.2557)\end{array}$ & $\begin{array}{l}0.1764 \\
(0.1107)\end{array}$ & $\begin{array}{l}-0.0463 \\
(0.6778)\end{array}$ & $\begin{array}{l}-0.0464 \\
(0.6767)\end{array}$ & $\begin{array}{l}-0.0206 \\
(0.8531)\end{array}$ \\
\hline Beta_a & & $\begin{array}{l}1 \\
(0)\end{array}$ & $\begin{array}{l}-0.0071 \\
(0.9536)\end{array}$ & $\begin{array}{l}0.0594 \\
(0.6250)\end{array}$ & $\begin{array}{l}-0.1065 \\
(0.3802)\end{array}$ & $\begin{array}{l}0.1654 \\
(0.1712)\end{array}$ & $\begin{array}{l}0.0015 \\
(0.9902)\end{array}$ & $\begin{array}{l}0.1183 \\
(0.3292)\end{array}$ \\
\hline GAO & & & $\begin{array}{l}1 \\
(0)\end{array}$ & $\begin{array}{l}-0.0663 \\
(0.5517)\end{array}$ & $\begin{array}{l}0.3308 \\
(0.0023)\end{array}$ & $\begin{array}{l}-0.0314 \\
(0.7780)\end{array}$ & $\begin{array}{l}-0.1467 \\
(0.1857)\end{array}$ & $\begin{array}{l}-0.2435 \\
(0.0266)\end{array}$ \\
\hline GAF & & & & $\begin{array}{l}1 \\
(0)\end{array}$ & $\begin{array}{l}0.2142 \\
(0.0518)\end{array}$ & $\begin{array}{l}0.1290 \\
(0.2451)\end{array}$ & $\begin{array}{l}0.1918 \\
(0.0824)\end{array}$ & $\begin{array}{l}0.1861 \\
(0.0920)\end{array}$ \\
\hline GAT & & & & & $\begin{array}{l}1 \\
(0)\end{array}$ & $\begin{array}{l}0.0956 \\
(0.3892)\end{array}$ & $\begin{array}{l}-0.0748 \\
(0.5014)\end{array}$ & $\begin{array}{l}-0.2081 \\
(0.0591)\end{array}$ \\
\hline Índice & & & & & & $\begin{array}{l}1 \\
(0)\end{array}$ & $\begin{array}{l}0.0626 \\
(0.5740)\end{array}$ & $\begin{array}{l}-0.1332 \\
(0.2293) \\
\end{array}$ \\
\hline Luc_fin & & & & & & & $\begin{array}{l}1 \\
(0)\end{array}$ & $\begin{array}{l}0.1213 \\
(0.2748)\end{array}$ \\
\hline Luc_eco & & & & & & & & $\begin{array}{l}1 \\
(0)\end{array}$ \\
\hline
\end{tabular}

Fonte: Elaborada pelo Autor 
As únicas medidas que apresentaram correlações estatisticamente significantes a 5\% foram: beta em relação ao GAT; beta_a em relação ao índice; GAO em relação ao GAT; GAF em relação ao GAT e também lucratividade financeira e econômica. Os sinais são positivos.

A tabela a seguir, apresenta as correlações de Spearman com os efeitos da securitização e sem normalização.

Tabela 32 - Correlações de Spearman com os efeitos da securitização

\begin{tabular}{|c|c|c|c|c|c|c|c|c|}
\hline Sem Norm & Beta & Beta_a & GAO_sec & GAF_sec & GAT_sec & Índ_sec & Lu_fi_sec & Lu_ec_sec \\
\hline Beta & $\begin{array}{l}1 \\
(0)\end{array}$ & $\begin{array}{r}-0.0015 \\
(0.9900)\end{array}$ & $\begin{array}{c}0.0460 \\
(0.6795)\end{array}$ & $\begin{array}{l}0.1068 \\
(0.3364)\end{array}$ & $\begin{array}{l}0.2473 \\
(0.0242)\end{array}$ & $\begin{array}{l}0.0600 \\
(0.5898)\end{array}$ & $\begin{array}{l}0.3293 \\
(0.0024)\end{array}$ & $\begin{array}{l}0.2532 \\
(0.0209)\end{array}$ \\
\hline Beta_a & & $\begin{array}{l}1 \\
(0)\end{array}$ & $\begin{array}{l}-0.0071 \\
(0.9536)\end{array}$ & $\begin{array}{l}0.0269 \\
(0.8252)\end{array}$ & $\begin{array}{l}-0.1760 \\
(0.1450)\end{array}$ & $\begin{array}{l}0.1309 \\
(0.2802)\end{array}$ & $\begin{array}{l}-0.1376 \\
(0.2561)\end{array}$ & $\begin{array}{l}-0.0724 \\
(0.5513)\end{array}$ \\
\hline GAO_sec & & & $\begin{array}{l}1 \\
(0)\end{array}$ & $\begin{array}{l}-0.0327 \\
(0.7691)\end{array}$ & $\begin{array}{l}0.1924 \\
(0.0814)\end{array}$ & $\begin{array}{l}0.4080 \\
(0.0001)\end{array}$ & $\begin{array}{l}0.2218 \\
(0.0439)\end{array}$ & $\begin{array}{l}0.0147 \\
(0.8950)\end{array}$ \\
\hline GAF_sec & & & & $\begin{array}{l}1 \\
(0)\end{array}$ & $\begin{array}{l}0.4526 \\
(0.0001)\end{array}$ & $\begin{array}{l}0.1998 \\
(0.0701)\end{array}$ & $\begin{array}{l}0.2168 \\
(0.0490)\end{array}$ & $\begin{array}{l}-0.0155 \\
(0.8895)\end{array}$ \\
\hline GAT_sec & & & & & $\begin{array}{l}1 \\
(0)\end{array}$ & $\begin{array}{l}0.2308 \\
(0.0358)\end{array}$ & $\begin{array}{l}0.4134 \\
(0.0001)\end{array}$ & $\begin{array}{l}0.0910 \\
(0.4130)\end{array}$ \\
\hline Índice_sec & & & & & & $\begin{array}{l}1 \\
(0)\end{array}$ & $\begin{array}{l}0.0729 \\
(0.5125)\end{array}$ & $\begin{array}{l}-0.2163 \\
(0.0495)\end{array}$ \\
\hline Lu_fin_sec & & & & & & & $\begin{array}{l}1 \\
(0)\end{array}$ & $\begin{array}{l}0.8365 \\
(0.0000)\end{array}$ \\
\hline Lu_eco_sec & & & & & & & & $\begin{array}{l}1 \\
(0)\end{array}$ \\
\hline
\end{tabular}

Fonte: Elaborada pelo Autor

As únicas medidas que apresentaram correlações estatisticamente significantes a $5 \%$ e com os sinais positivos foram: beta em relação ao GAT_sec; beta_a em relação a lucratividade financeira e economica; GAO_sec em relação ao GAT_sec, índice e lucratividade financeira; GAF_sec em relação ao GAT_sec, índice e lucratividade financeira .

Finalmente, a tabela a seguir, apresenta as correlações de Spearman com os efeitos da securitização e da normalização. 
Tabela 33 - Correlações de Spearman com os efeitos da securitização Normalizada

\begin{tabular}{|c|c|c|c|c|c|c|c|c|}
\hline Com Norm & Beta & Beta_a & GAO_sec & GAF_sec & GAT_sec & Índ_sec & Lu_fi_sec & Lu_ec_sec \\
\hline Beta & 1 & $\begin{array}{l}-0.0015 \\
(0.9900)\end{array}$ & $\begin{array}{l}0.0460 \\
(0.6795)\end{array}$ & $\begin{array}{l}0.1068 \\
(0.3364)\end{array}$ & $\begin{array}{l}0.2473 \\
(0.0242)\end{array}$ & $\begin{array}{l}0.0600 \\
(0.5898)\end{array}$ & $\begin{array}{l}0.3293 \\
(0.0024)\end{array}$ & $\begin{array}{l}0.2532 \\
(0.0209)\end{array}$ \\
\hline Beta_a & & 1 & $\begin{array}{l}-0.0071 \\
(0.9536)\end{array}$ & $\begin{array}{l}0.0269 \\
(0.8252)\end{array}$ & $\begin{array}{l}-0.1760 \\
(0.1450)\end{array}$ & $\begin{array}{l}0.1309 \\
(0.2802)\end{array}$ & $\begin{array}{l}-0.1376 \\
(0.2561)\end{array}$ & $\begin{array}{l}-0.0724 \\
(0.5513)\end{array}$ \\
\hline GAO_sec & & & 1 & $\begin{array}{l}-0.0327 \\
(0.7691)\end{array}$ & $\begin{array}{l}0.1924 \\
(0.0814)\end{array}$ & $\begin{array}{l}0.4080 \\
(0.0001)\end{array}$ & $\begin{array}{l}0.2218 \\
(0.0439)\end{array}$ & $\begin{array}{l}0.0147 \\
(0.8950)\end{array}$ \\
\hline GAF_sec & & & & 1 & $\begin{array}{l}0.4526 \\
(0.0000)\end{array}$ & $\begin{array}{l}0.1998 \\
(0.0701)\end{array}$ & $\begin{array}{l}0.0074 \\
(0.9469)\end{array}$ & $\begin{array}{l}-0.0363 \\
(0.7447)\end{array}$ \\
\hline GAT_sec & & & & & 1 & $\begin{array}{l}0.2308 \\
(0.0358)\end{array}$ & $\begin{array}{l}0.4134 \\
(0.0001)\end{array}$ & $\begin{array}{l}0.0910 \\
(0.4130)\end{array}$ \\
\hline Índice_sec & & & & & & 1 & $\begin{array}{l}0.0729 \\
(0.5125)\end{array}$ & $\begin{array}{l}-0.2163 \\
(0.1644)\end{array}$ \\
\hline Lu_fin_sec & & & & & & & 1 & $\begin{array}{l}0.0391 \\
(0.0495) \\
\end{array}$ \\
\hline Lu_eco_sec & & & & & & & & 1 \\
\hline
\end{tabular}

Fonte: Elaborada pelo Autor

Constata-se que, os indicadores testados com os efeitos da securitização e da normalização acarretaram valores de correlações maiores que os indicadores sem o efeito da securitização e da normalização. Todas as correlações de Spearman estatisticamente significantes a $5 \%$ têm os sinais positivos e foram: beta em relação ao GAT_sec ; beta_a em relação a lucratividade financeira e economica; GAO_sec em relação ao GAT_sec, índice e lucratividade financeira e GAF_sec em relação ao GAT_sec.

As tabelas 32 e 33, consideram dados coletados a partir do início da securitização de ativos e, demonstram que os resultados indicam falta de significância estatística entre uma parte das variáveis. Por outro lado, as variáveis GAT, GAF, GAO, índice de endividamento e lucratividade financeira, foram as que se mostraram mais associadas com os betas de mercado. Esses resultados assemelham-se aos resultados anteriormente apresentados nas correlações de Pearson com securitização desta seção. 


\section{4 - Resumo dos Resultados Encontrados nas Matrizes de Correlação de Pearson e Spearman}

Quadro 20 - Matrizes de correlação e resultados observados

\begin{tabular}{|c|l|}
\hline Matriz de Correlação & \multicolumn{1}{|c|}{ Resultados Observados } \\
\hline Pearson sem securitização & $\begin{array}{l}\text { Sem relação entre os graus de alavancagem e o } \\
\text { beta, beta alavancado e indicadores de } \\
\text { lucratividade }\end{array}$ \\
\hline Pearson com securitização & $\begin{array}{l}\text { Relação satisfatória entre os graus de } \\
\text { alavancagem (GAT e GAF) e o beta, beta } \\
\text { alavancado e indicadores de lucratividade }\end{array}$ \\
\hline Spearman sem securitização & $\begin{array}{l}\text { Sem relação entre os graus de alavancagem e o } \\
\text { beta, beta alavancado e indicadores de } \\
\text { lucratividade }\end{array}$ \\
\hline Spearman com securitização & $\begin{array}{l}\text { Relação satisfatória entre os graus de } \\
\text { alavancagem (GAT e GAF) e o beta, beta } \\
\text { alavancado e indicadores de lucratividade }\end{array}$ \\
\hline
\end{tabular}

Fonte: Elaborado pelo Autor

Conforme indicam os resultados das correlações de Pearson e Spearman, de acordo com esse quadro, observam-se evidências da possibilidade de correlações estatisticamente significantes entre as mesmas variáveis que se destacaram em ambos os modelos de correlações, com os efeitos da securitização.

Em resumo, das quatro hipóteses analisadas por meio das correlações de Pearson, somente a terceira não foi confirmada, e pela de Spearman, somente a segunda não foi confirmada. Assim, surge uma dicotomia entre as duas análises que será avaliada via implicação fuzzy conforme demonstrado na próxima seção. As correlações, principalmente as de Spearman, são positivas. Observa-se que as intensidades destas associações aumentam geralmente com a securitização e a normalização.

\section{5 - Resultados da Análise Estatística Fuzzy}

As mesmas hipóteses analisadas anteriormente por meio de regressões e de correlações serão testadas também por meio de implicações fuzzy. Três tipos de 
implicações fuzzy são avaliados: Reichenbach, Kleene e Lukasiewicz, conforme demonstração na seção 5.6.1a seguir.

A semântica das implicações fuzzy (relações) entre os indicadores, de acordo com a teoria formulada na seção 4.12.4, são expressas das seguintes maneiras:

- alavancagem ou dívidas de longo prazo alta implicam necessariamente em se obter alta lucratividade;

- alavancagem ou dívidas de longo prazo média implicam na necessidade de lucratividade média ou alta;

- alavancagem baixa não implica necessariamente em nenhum nível de lucratividade.

Portanto, foram testados três tipos de implicações na análise estatística fuzzy. As relações entre o nível de endividamento, alavancagem, bem como a lucratividade financeira e econômica foram privilegiadas por esses testes.

\section{6 - Simulações com a Estatística Fuzzy}

\subsection{1 - Dados e Simulações}

Doze medidas de implicações fuzzy são analisadas numa amostra de população de 18 importantes empresas brasileiras. Três tipos de implicações fuzzy são avaliadas: Reichenbach, Kleene e Lukasiewicz.

Testaram-se essas medidas de implicação em empresas de vários setores econômicos de atividade no período de 2000 a 2005, que incluem os setores: comunicações, celulose, textil, químico, mineração, elétrico, telefonia, varejo entre outros, que realizaram operações de securitização de recebíveis nesse mesmo período. 
Calcularam-se os 08 (oito) índices listados de acordo com o quadro a seguir, para todas as empresas da amostragem. Destaque-se que a escolha de vários setores da economia, conforme amostra, significou a aceitação de uma dispersão elevada.

\section{Quadro 21 - Lista de indicadores}

\begin{tabular}{|c|c|}
\hline $\begin{array}{l}\text { (1) Dívida Total / Total do Ativo } \\
\text { (endividamento) }\end{array}$ & (2) GAT (alavancagem) \\
\hline (3) GAF (alavancagem financeira) & (4) GAO (alavancagem operacional) \\
\hline $\begin{array}{l}\text { (5) Lucro Líquido / Patrimônio Líquido } \\
\text { (lucratividade financeira) }\end{array}$ & $\begin{array}{l}\text { (6) Receita Operacional / Total do Ativo } \\
\text { (lucratividade econômica ) }\end{array}$ \\
\hline (7) Beta & (8) Beta alavancado \\
\hline
\end{tabular}

Fonte: Elaborado pelo Autor

Conforme os indicadores nesse quadro, os índices de 1 a 4 representam parte da estrutura de capital das empresas, bem como, parte de seu nível de endividamento de curto e longo prazos. Já o índice 5 é a fórmula convencional da lucratividade financeira em relação ao patrimônio líquido, ou seja, o resultado sobre o patrimônio líquido. A lucratividade das empresas conforme o índice 6 é calculada antes dos impostos e custos não recorrentes. Finalmente, Os índices de 7 e 8 representam o risco de mercado e o risco alavancado.

Após o processamento dos indicadores, citados no quadro anterior, no período sem a securitização e no período após o início da securitização, foi realizada a média e dispersão desses índices, conforme demonstrado na tabela a seguir: 
Tabela 34 - Média e dispersão dos índices com e sem securitização de ativos

\begin{tabular}{|c|c|c|c|c|}
\hline Indices & Mínimo & Máximo & Média & Desvio Padrão \\
\hline Dívida Total & 0.15 & 84.65 & 54.53 & 19.86 \\
\hline Alavancagem & 0.15 & 1,280 & 183.84 & 180.90 \\
\hline Lucratividade Financeira & -57.03 & 89.00 & 7.81 & 22.18 \\
\hline Lucratividade Econômica & -20.79 & 32.65 & 5.25 & 8.97 \\
\hline Dívida Total_sec & 0 & 62.01 & 30.01 & 15.86 \\
\hline Alavancagem_sec & -60.90 & 274.58 & 62.71 & 71.75 \\
\hline Lucrativ. Financeira_sec & -57.03 & 131.76 & 24.54 & 27.26 \\
\hline Lucrativ. Econômica_sec & -21.08 & 59.21 & 9.91 & 10.66 \\
\hline
\end{tabular}

Fonte: Elaborada pelo Autor

Nota-se nessa tabela que, a securitização na média, aumenta a lucratividade e diminui os desvios-padrão, sendo positiva para as empresas. Entretanto, mesmo após a eliminação dos pontos extremos (outliers) e das empresas que não possuíram dados em algum período, as variáveis apresentaram grande variação em seus dados, verificando-se desvios-padrão expressivos.

Em resumo, das quatro hipóteses analisadas por meio das correlações de Pearson, somente a terceira não foi confirmada, e pela de Spearman, somente a segunda não foi confirmada. Assim, surge uma dicotomia entre as duas análises que será avaliada via implicação fuzzy. As correlações, principalmente as de Spearman, são positivas. Observa-se que as intensidades destas associações aumentam geralmente com a securitização e a normalização.

Outra forma de ver os mesmos resultados é dizer que baixa lucratividade pode resultar somente de alavancagem baixa ou baixo nível de endividamento a longo prazo. Observe que, na lógica fuzzy, isso é válido se a intensidade impactante for 1 , mas a força do impacto, em nossa análise, é uma variável difusa e varia no intervalo $[0,1]$.

Como já mencionado, a estrutura financeira das empresas foi avaliada através de 6 índices e mais o Beta e Beta Alavancado. O Grau de alavancagem total (índice 2), freqüentemente chamado de GAT, será simplesmente, nesse trabalho, alavancagem. Passivo circulante oneroso + exigível de longo prazo oneroso / total de ativos (índice 1), é também chamado de índice de endividamento total. 
Complementando, têm-se as lucratividades, econômica e financeira, (índices 5 e 6 ), alcançadas pelas empresas.

Assim, aplicando-se a estatística convencional aliada à lógica fuzzy, obteve-se os resultados demonstrados nas tabelas (35 a 38), bem como as respectivas representações gráficas, nesta seção, que sinalizam as áreas de rejeição e nãorejeição das relações entre as variáveis testadas.

Assim, a parte de cima dos gráficos, conforme mencionado na seção 4.12 .5 (figura 11), acima da diagonal, define a região de aceitação. A parte abaixo da diagonal define a região de rejeição, de acordo coma a semântica apresentada anteriormente. A freqüência dos pontos na região de aceitação em relação ao total de amostras é utilizada para calcular a proporção de amostras aceitas e gera a intensidade da relação e o nível de confiança.

Os gráficos 5.1 a a $5.16 \mathrm{~d}$, ilustrados em seguida, apresentam as freqüências dos pontos nas regiões de aceitação e de rejeição. 
Figuras 5.1a a 5.4c: Gráficos das implicações fuzzy sem securitização ativos

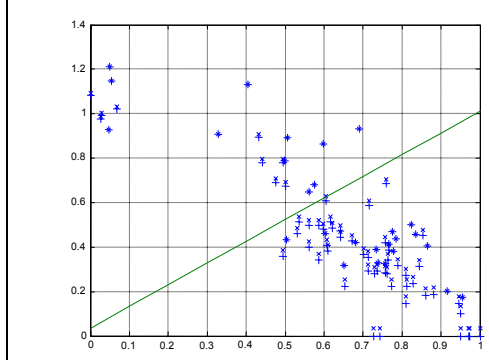

Figura 5.1a: dívida total $\rightarrow$ lucratividade econômica (implicação de Lukasiewicz)

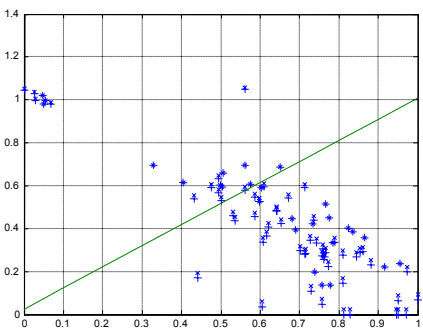

Figura 5.2a: dívida total $\rightarrow$ lucratividade financeira (implicação de Lukasiewicz)

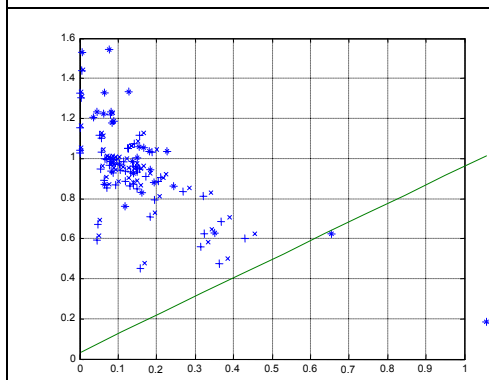

Figura 5.3a: alavancagem $\rightarrow$ lucratividade econômica (implicação de Lukasiewicz)

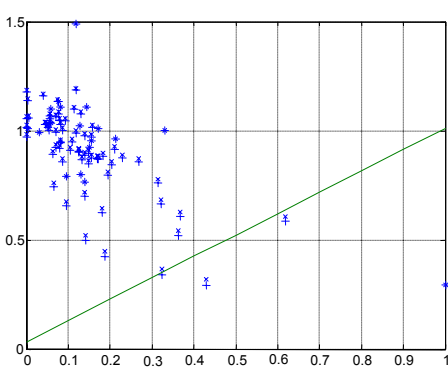

Figura 5.4a alavancagem $\rightarrow$ lucratividade financeira (implicação de Lukasiewicz)

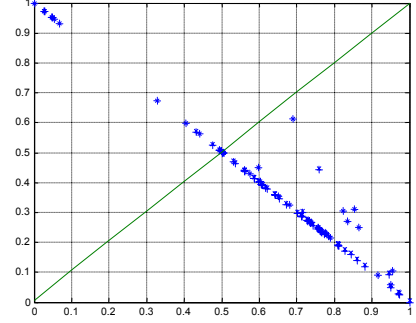

Figura 5.1b: dívida total $\rightarrow$ lucratividade econômica (implicação de Kleene)

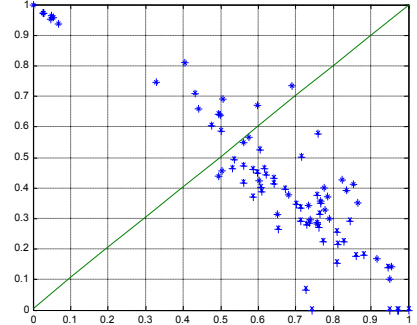

Figura 5.1c: dívida total $\rightarrow$ lucratividade econômica (implicação de Reichenbach)

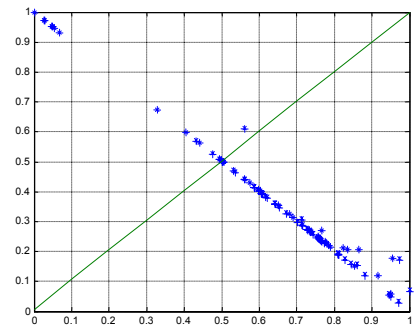

Figura 5.2b: dívida total $\rightarrow$ lucratividade financeira (implicação de Kleene)

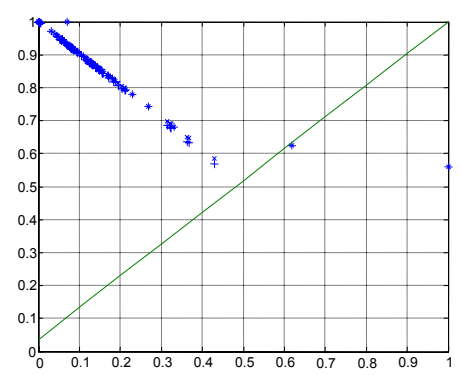

Figura 5.3b: alavancagem $\rightarrow$ lucratividade econômica (implicação de Kleene)

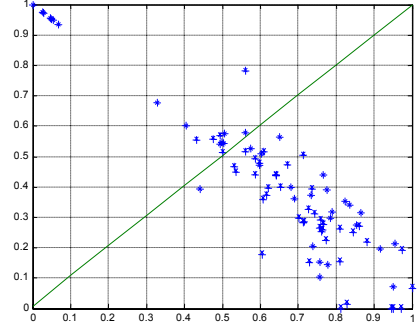

Figura 5.2c: dívida total $\rightarrow$ lucratividade financeira (implicação de Reichenbach)

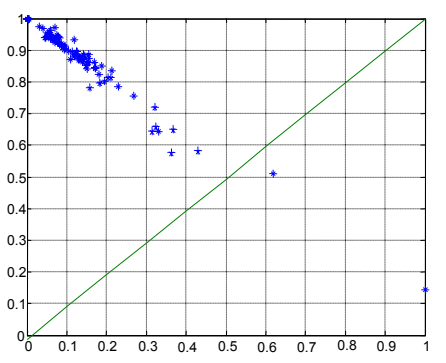

Figura 5.3c: alavancagem $\rightarrow$ lucratividade econômica (implicação de Reichenbach)

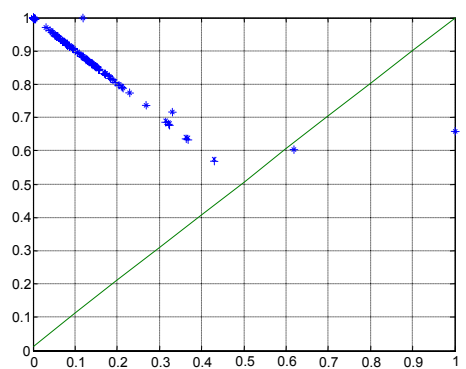

Figura 5.4b: alavancagem $\rightarrow$ lucratividade financeira (implicação de Kleene)

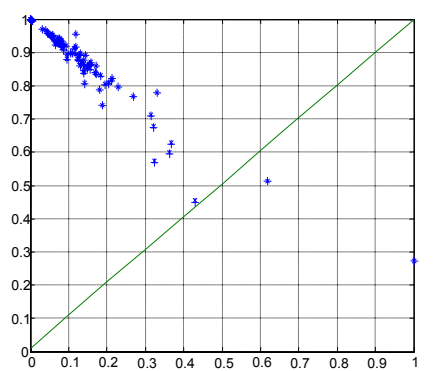

Figura 5.4c: alavancagem $\rightarrow$ lucratividade financeira (implicação de Reichenbach)

Fonte: Elaborado pelo Autor 
Figuras 5.5a a 5.8c: Gráficos das implicações fuzzy com securitização ativos

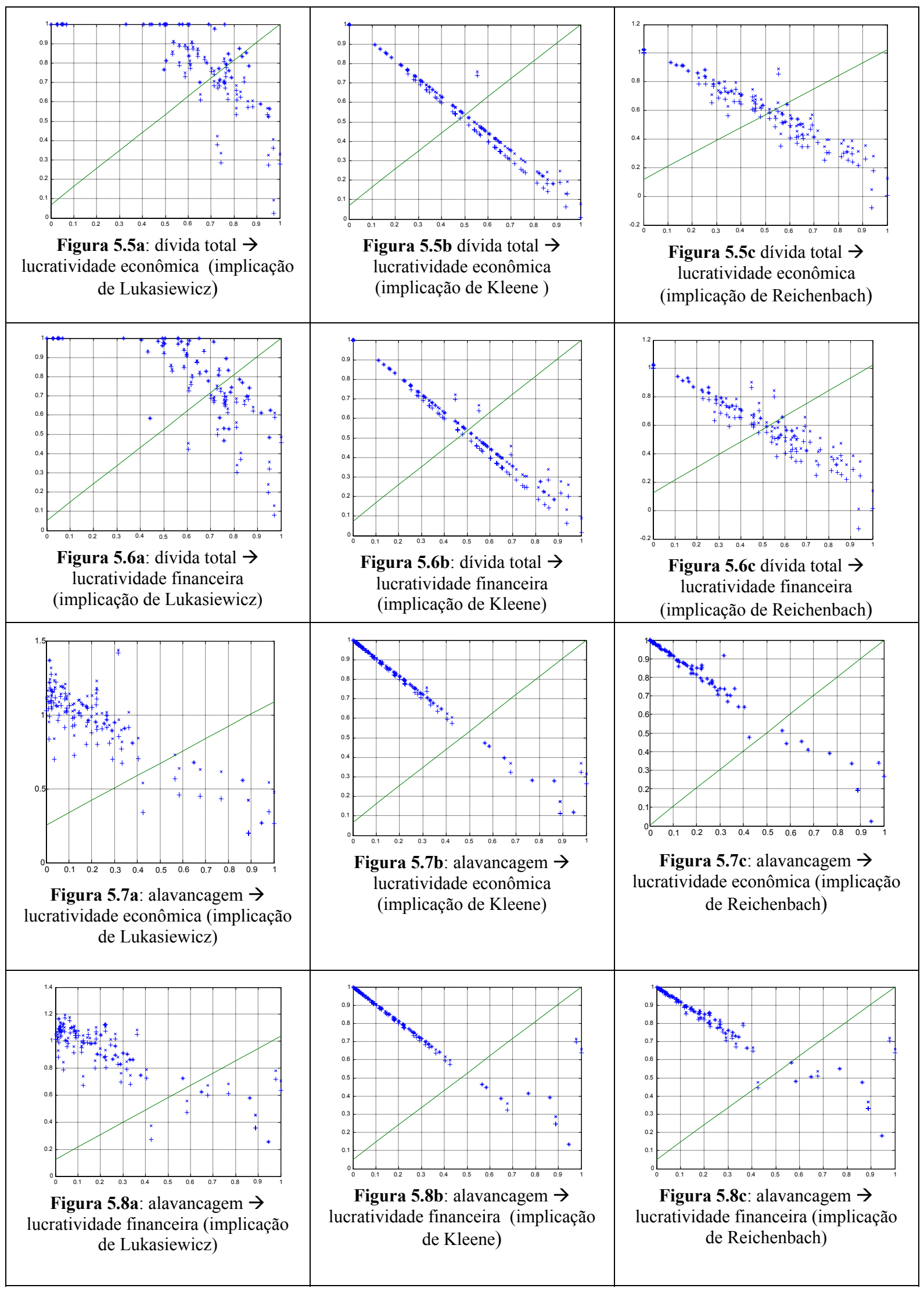

Fonte: Elaborado pelo Autor 
Figuras 5.9a a 5.12c: Gráficos das estatísticas fuzzy com securitização ativos

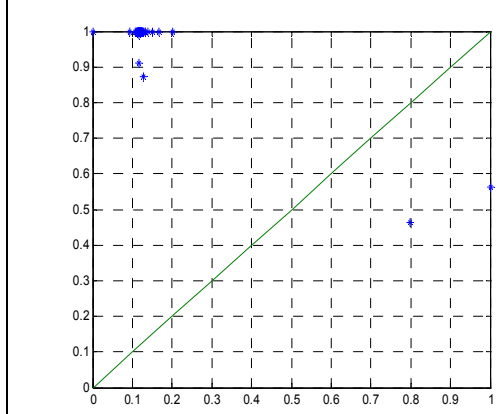

Figura 5.9a: GAF $\rightarrow$ lucratividade econômica (implicação de Lukasiewicz)

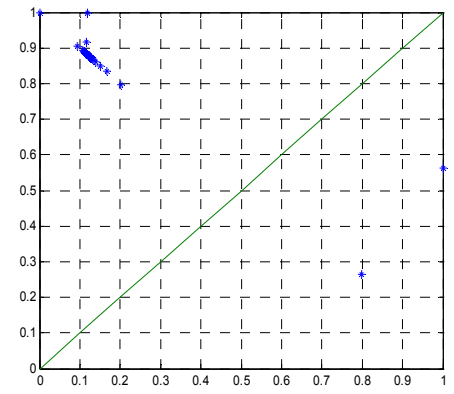

Figura 5.9b GAF $\rightarrow$ lucratividade econômica (implicação de Kleene )

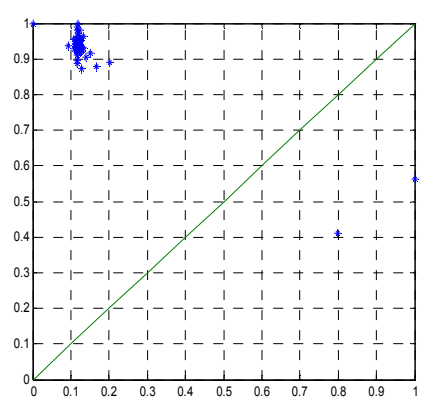

Figura 5.9c GAF $\rightarrow$ lucratividade econômica (implicação de Reichenbach)

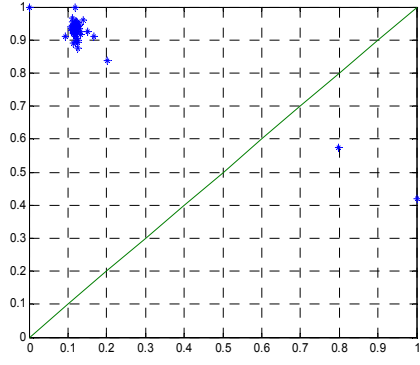

Figura 5.10c GAF $\rightarrow$ lucratividade

Figura 5.10b: GAF $\rightarrow$ lucratividade financeira (implicação de Kleene)
Figura 5.10a: GAF $\rightarrow$ lucratividade financeira (implicação de Lukasiewicz)
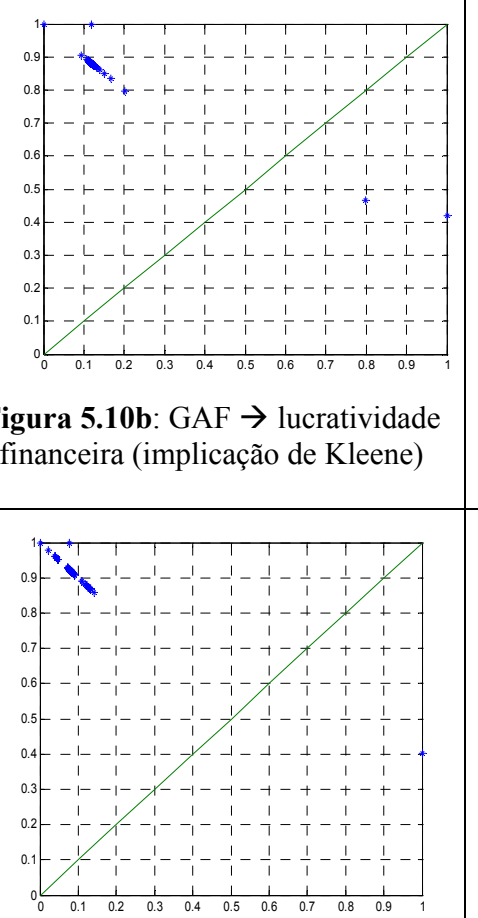

Figura 5.11a: GAO $\rightarrow$ lucratividade econômica (implicação de Lukasiewicz)
Figura 5.11b: GAO $\rightarrow$ lucratividade econômica (implicação de Kleene)

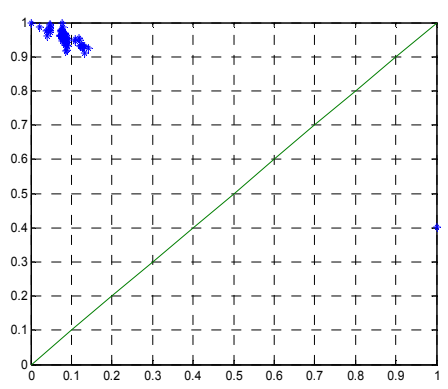

Figura 5.11c: GAO $\rightarrow$ lucratividade econômica (implicação de Reichenbach)

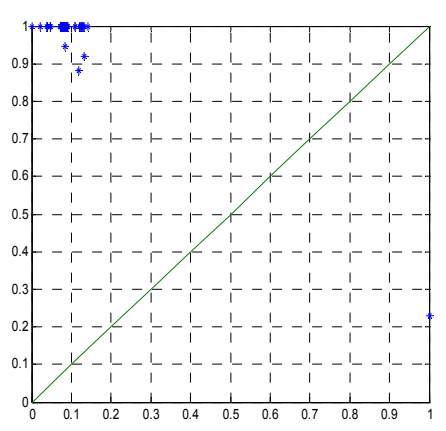

Figura 5.12a: GAO $\rightarrow$ lucratividade financeira (implicação de Lukasiewicz)

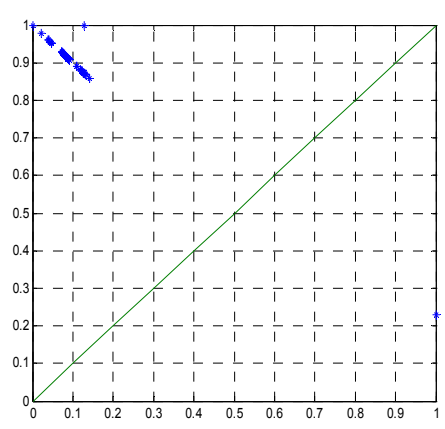

Figura 5.12b: GAO $\rightarrow$ lucratividade financeira (implicação de Kleene)

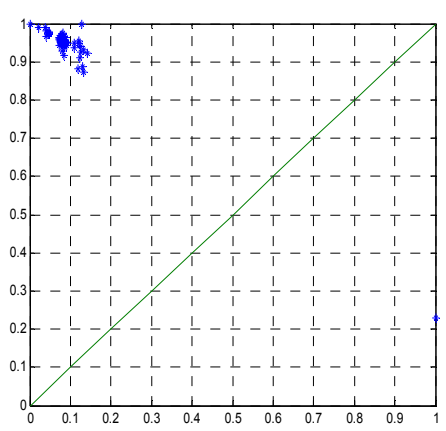

Figura 5.12c: GAO $\rightarrow$ lucratividade financeira (implicação de Reichenbach)

Fonte: Elaborado pelo Autor 
Figuras 5.13a a 5.16c: Gráficos das implicações fuzzy com securitização ativos

\begin{tabular}{|c|c|c|}
\hline 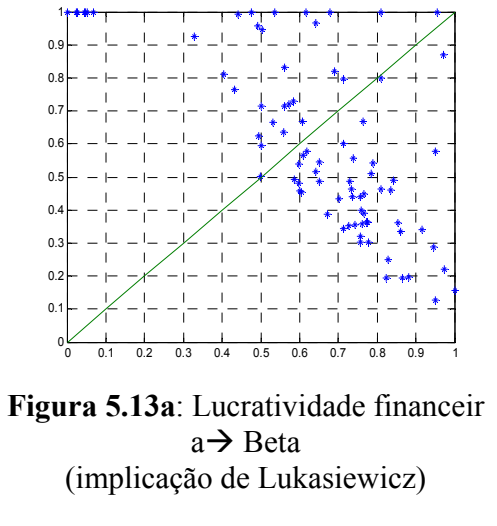 & 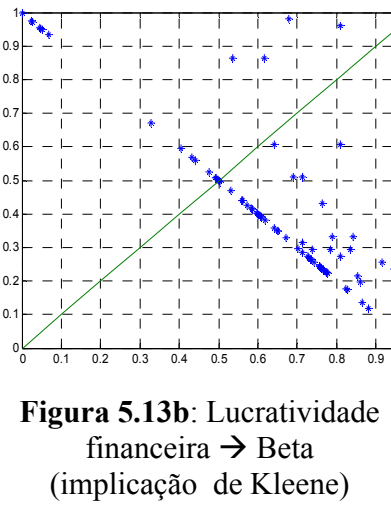 & 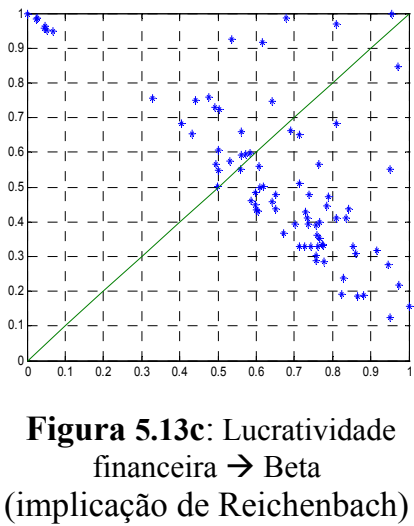 \\
\hline 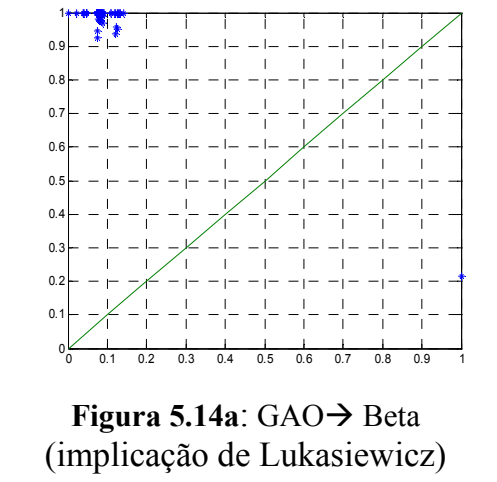 & 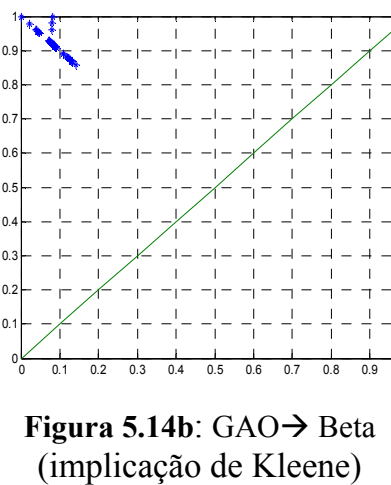 & 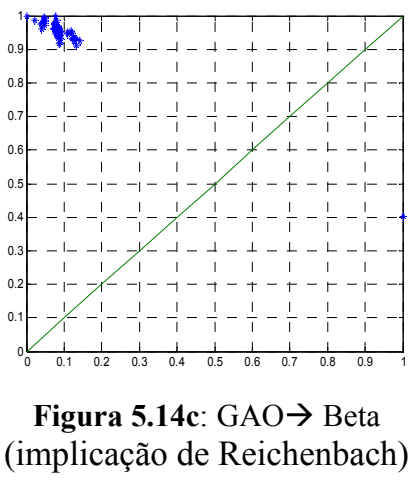 \\
\hline $\begin{array}{c}\text { Figura 5.15a: GAF } \rightarrow \text { Beta } \\
\text { (implicação de Lukasiewicz) }\end{array}$ & 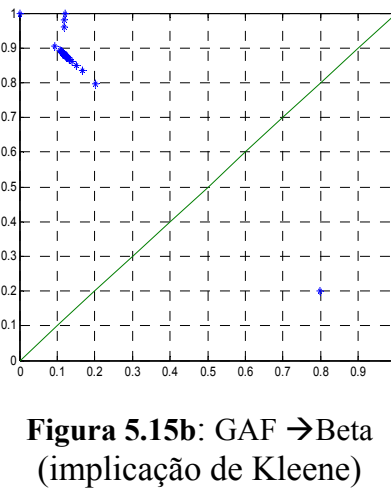 & 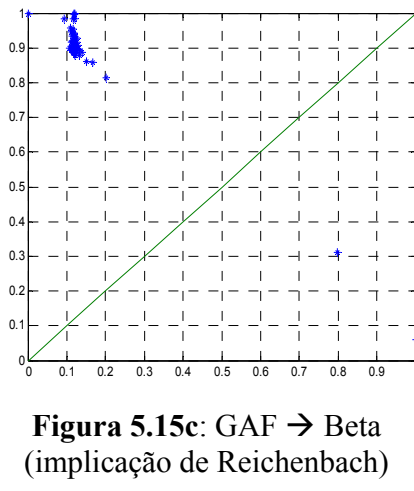 \\
\hline $\begin{array}{c}\text { Figura 5.16a GAT } \rightarrow \text { Beta } \\
\text { (implicação de Lukasiewicz ) }\end{array}$ & $\begin{array}{l}\text { Figura 5.16b: GAT } \rightarrow \text { Beta } \\
\text { (implicação de Kleene) }\end{array}$ & 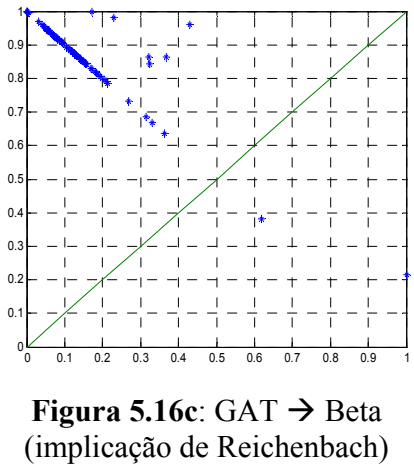 \\
\hline
\end{tabular}

Fonte: Elaborado pelo Autor 
Tabela 35 - Resultados das implicações fuzzy sem a securitização de ativos

\begin{tabular}{|c|c|c|c|c|c|c|}
\hline Implicação & Relação & $\mathbf{n}$ & $\mathbf{n}_{\mathbf{b}}$ & $\mathbf{n}_{\mathbf{a}}$ & $\begin{array}{c}\mathrm{m} \\
\text { (implicação) }\end{array}$ & $1-\boldsymbol{\alpha}$ \\
\hline Lukasiewicz & $\begin{array}{l}\text { InEndTot } \rightarrow \\
\text { lucratividade } \\
\text { econômica }\end{array}$ & 83 & 21 & 62 & 0.25 & $98 \%$ \\
\hline Lukasiewicz & $\begin{array}{c}\text { InEndTot } \rightarrow \\
\text { lucratividade } \\
\text { financeira }\end{array}$ & 83 & 22 & 61 & 0.27 & $99 \%$ \\
\hline Lukasiewicz & $\begin{array}{c}\text { alavancagem } \\
\rightarrow \\
\text { lucratividade } \\
\text { econômica }\end{array}$ & 83 & 81 & 2 & 0.98 & $99 \%$ \\
\hline Lukasiewicz & $\begin{array}{c}\text { alavancagem } \\
\rightarrow \\
\text { lucratividade } \\
\text { financeira }\end{array}$ & 83 & 80 & 3 & 0.96 & $99 \%$ \\
\hline Kleene & $\begin{array}{c}\text { InEndLP } \rightarrow \\
\text { lucratividade } \\
\text { econômica }\end{array}$ & 83 & 15 & 68 & 0.18 & $95 \%$ \\
\hline Kleene & $\begin{array}{c}\text { InEndLP } \rightarrow \\
\text { lucratividade } \\
\text { financeira }\end{array}$ & 83 & 16 & 67 & 0.19 & $96 \%$ \\
\hline Kleene & $\begin{array}{c}\text { alavancagem } \\
\rightarrow \\
\text { lucratividade } \\
\text { econômica }\end{array}$ & 83 & 81 & 2 & 0.98 & $99 \%$ \\
\hline Kleene & $\begin{array}{c}\text { alavancagem } \\
\rightarrow \\
\text { lucratividade } \\
\text { financeira }\end{array}$ & 83 & 81 & 2 & 0.98 & $99 \%$ \\
\hline Reichenbach & $\begin{array}{c}\text { InEndTot } \rightarrow \\
\text { lucratividade } \\
\text { econômica }\end{array}$ & 83 & 18 & 65 & 0.22 & $97 \%$ \\
\hline Reichenbach & $\begin{array}{c}\text { InEndTot } \rightarrow \\
\text { lucratividade } \\
\text { financeira }\end{array}$ & 83 & 19 & 64 & 0.23 & $98 \%$ \\
\hline Reichenbach & $\begin{array}{c}\text { alavancagem } \\
\rightarrow \\
\text { lucratividade } \\
\text { econômica } \\
\end{array}$ & 83 & 81 & 2 & 0.98 & $99 \%$ \\
\hline Reichenbach & $\begin{array}{c}\text { alavancagem } \\
\rightarrow \\
\text { lucratividade } \\
\text { financeira } \\
\end{array}$ & 83 & 81 & 2 & 0.98 & $99 \%$ \\
\hline
\end{tabular}

Fonte: Elaborada pelo Autor 
Tabela 36 - Resultados das implicações fuzzy com a securitização de ativos

\begin{tabular}{|c|c|c|c|c|c|c|}
\hline Implicação & Relação & $\mathrm{n}$ & $\mathrm{n}_{\mathrm{b}}$ & $\mathrm{n}_{\mathrm{a}}$ & $\begin{array}{c}\mathrm{m} \\
\text { (implicação) } \\
\end{array}$ & $1-\alpha$ \\
\hline Lukasiewicz & $\begin{array}{l}\text { InEndTot } \rightarrow \\
\text { lucratividade } \\
\text { econômica }\end{array}$ & 83 & 48 & 35 & 0.58 & $99 \%$ \\
\hline Lukasiewicz & $\begin{array}{l}\text { InEndTot } \rightarrow \\
\text { lucratividade } \\
\text { financeira }\end{array}$ & 83 & 48 & 35 & 0.58 & $99 \%$ \\
\hline Lukasiewicz & $\begin{array}{c}\text { alavancagem } \\
\rightarrow \\
\text { lucratividade } \\
\text { econômica }\end{array}$ & 83 & 72 & 11 & 0.87 & $99 \%$ \\
\hline Lukasiewicz & $\begin{array}{c}\text { alavancagem } \\
\rightarrow \\
\text { lucratividade } \\
\text { financeira } \\
\end{array}$ & 83 & 72 & 11 & 0.87 & $99 \%$ \\
\hline Kleene & $\begin{array}{l}\text { InEndTot } \rightarrow \\
\text { lucratividade } \\
\text { econômica }\end{array}$ & 83 & 42 & 41 & 0.51 & $99 \%$ \\
\hline Kleene & $\begin{array}{l}\text { InEndTot } \rightarrow \\
\text { lucratividade } \\
\text { financeira }\end{array}$ & 83 & 42 & 41 & 0.51 & $99 \%$ \\
\hline Kleene & $\begin{array}{c}\text { alavancagem } \\
\rightarrow \\
\text { lucratividade } \\
\text { econômica }\end{array}$ & 83 & 72 & 11 & 0.87 & $99 \%$ \\
\hline Kleene & $\begin{array}{c}\text { alavancagem } \\
\rightarrow \\
\text { lucratividade } \\
\text { financeira }\end{array}$ & 83 & 72 & 11 & 0.87 & $99 \%$ \\
\hline Reichenbach & $\begin{array}{l}\text { InEndTot } \rightarrow \\
\text { lucratividade } \\
\text { econômica }\end{array}$ & 83 & 44 & 39 & 0.53 & $99 \%$ \\
\hline Reichenbach & $\begin{array}{l}\text { InEndTot } \rightarrow \\
\text { lucratividade } \\
\text { financeira }\end{array}$ & 83 & 45 & 38 & 0.54 & $99 \%$ \\
\hline Reichenbach & $\begin{array}{c}\text { alavancagem } \\
\rightarrow \\
\text { lucratividade } \\
\text { econômica }\end{array}$ & 83 & 72 & 11 & 0.87 & $99 \%$ \\
\hline Reichenbach & $\begin{array}{c}\text { alavancagem } \\
\rightarrow \\
\text { lucratividade } \\
\text { financeira }\end{array}$ & 83 & 72 & 11 & 0.87 & $99 \%$ \\
\hline
\end{tabular}

Fonte: Elaborada pelo Autor 
Tabela 37 - Resultados das implicações fuzzy com a securitização de ativos

\begin{tabular}{|c|c|c|c|c|c|c|}
\hline Implicação & Relação & $\mathrm{n}$ & $\mathrm{n}_{\mathrm{b}}$ & $\mathrm{n}_{\mathrm{a}}$ & $\begin{array}{c}\text { M } \\
\text { (implicação) }\end{array}$ & $1-\boldsymbol{\alpha}$ \\
\hline Lukasiewicz & $\begin{array}{c}\text { GAF } \rightarrow \\
\text { lucratividade } \\
\text { econômica }\end{array}$ & 83 & 2 & 81 & 0.98 & $100 \%$ \\
\hline Lukasiewicz & $\begin{array}{c}\text { GAF } \rightarrow \\
\text { lucratividade } \\
\text { financeira }\end{array}$ & 83 & 2 & 81 & 0.98 & $100 \%$ \\
\hline Lukasiewicz & $\begin{array}{c}\text { GAO } \rightarrow \\
\text { lucratividade } \\
\text { econômica }\end{array}$ & 83 & 1 & 82 & 0.98 & $99 \%$ \\
\hline Lukasiewicz & $\begin{array}{c}\mathrm{GAO} \rightarrow \\
\text { lucratividade } \\
\text { financeira }\end{array}$ & 83 & 1 & 82 & 0.98 & $99 \%$ \\
\hline Kleene & $\begin{array}{c}\text { GAF } \rightarrow \\
\text { lucratividade } \\
\text { econômica }\end{array}$ & 83 & 2 & 81 & 0.98 & $100 \%$ \\
\hline Kleene & $\begin{array}{c}\text { GAF } \rightarrow \\
\text { lucratividade } \\
\text { financeira }\end{array}$ & 83 & 2 & 81 & 0.98 & $100 \%$ \\
\hline Kleene & $\begin{array}{c}\text { GAO } \rightarrow \\
\text { lucratividade } \\
\text { econômica }\end{array}$ & 83 & 1 & 82 & 0.98 & $99 \%$ \\
\hline Kleene & $\begin{array}{c}\mathrm{GAO} \rightarrow \\
\text { lucratividade } \\
\text { financeira }\end{array}$ & 83 & 1 & 82 & 0.98 & $99 \%$ \\
\hline Reichenbach & $\begin{array}{c}\text { GAF } \rightarrow \\
\text { lucratividade } \\
\text { econômica }\end{array}$ & 83 & 2 & 81 & 0.98 & $100 \%$ \\
\hline Reichenbach & $\begin{array}{c}\text { GAF } \rightarrow \\
\text { lucratividade } \\
\text { financeira }\end{array}$ & 83 & 2 & 81 & 0.98 & $100 \%$ \\
\hline Reichenbach & $\begin{array}{c}\text { GAO } \rightarrow \\
\text { lucratividade } \\
\text { econômica }\end{array}$ & 83 & 1 & 82 & 0.98 & $99 \%$ \\
\hline Reichenbach & $\begin{array}{c}\mathrm{GAO} \rightarrow \\
\text { lucratividade } \\
\text { financeira }\end{array}$ & 83 & 1 & 82 & 0.98 & $99 \%$ \\
\hline
\end{tabular}

Fonte: Elaborada pelo Autor 
Tabela 38 - Resultados estatísticos e fuzzy com a securitização de ativos

\begin{tabular}{|c|c|c|c|c|c|c|}
\hline Implicação & Relação & $\mathrm{n}$ & $\mathrm{n}_{\mathrm{b}}$ & $\mathrm{n}_{\mathrm{a}}$ & $\begin{array}{c}\text { M } \\
\text { (implicação) }\end{array}$ & $1-\boldsymbol{\alpha}$ \\
\hline Lukasiewicz & $\begin{array}{c}\text { InEndTot } \rightarrow \\
\text { beta }\end{array}$ & 83 & 50 & 33 & 0.397 & $40 \%$ \\
\hline Lukasiewicz & GAT $\rightarrow$ beta & 83 & 2 & 81 & 0.98 & $98 \%$ \\
\hline Lukasiewicz & GAF $\rightarrow$ beta & 83 & 2 & 81 & 0.98 & $98 \%$ \\
\hline Lukasiewicz & GAO $\rightarrow$ beta & 83 & 1 & 82 & 0.98 & $99 \%$ \\
\hline Kleene & $\begin{array}{c}\text { InEndTot } \rightarrow \\
\text { beta }\end{array}$ & 83 & 62 & 21 & 0.253 & $25 \%$ \\
\hline Kleene & GAT $\rightarrow$ beta & 83 & 2 & 81 & 0.98 & $98 \%$ \\
\hline Kleene & GAF $\rightarrow$ beta & 83 & 2 & 81 & 0.98 & $98 \%$ \\
\hline Kleene & GAO $\rightarrow$ beta & 83 & 1 & 82 & 0.98 & $99 \%$ \\
\hline Reichenbach & $\begin{array}{c}\text { InEndTot } \rightarrow \\
\text { beta }\end{array}$ & 83 & 54 & 29 & 0.349 & $35 \%$ \\
\hline Reichenbach & GAT $\rightarrow$ beta & 83 & 2 & 81 & 0.98 & $98 \%$ \\
\hline Reichenbach & GAF $\rightarrow$ beta & 83 & 2 & 81 & 0.98 & $98 \%$ \\
\hline Reichenbach & GAO $\rightarrow$ beta & 83 & 1 & 82 & 0.98 & $99 \%$ \\
\hline
\end{tabular}

Fonte: Elaborada pelo Autor

Entre os resultados obtidos, os que se seguem foram considerados os mais importantes:

1. Os três tipos de implicação (Lukasiewicz, Kleene e Reichenbach) apresentaram resultados consistentes e semelhantes.

2. O valor mais baixo de implicação é dado por endividamento total =>lucratividade econômica e a regra semântica das implicações diretas $(\operatorname{imp}(x, y))$. A aparência bastante semelhante de alguns agrupamentos de pontos deve ser observada. Esses agrupamentos podem ser usados para a verificação de padrões e podem ser interpretados, por exemplo, da seguinte forma: alavancagem forte implica em uma obrigação de se obter alta lucratividade (econômica e financeira); alavancagem média, implica em uma obrigação de se obter lucratividade média ou alta; alavancagem baixa não implica em nenhuma obrigação em obter lucratividade média ou alta. 
3. Estes resultados são certamente específicos das empresas analisadas. Entretanto, os valores altos obtidos para as implicações mostram claramente que as estruturas financeiras escolhidas por essas empresas (alavancagem) têm influências nas lucratividades e nos riscos (beta).

4. A securitização de ativos provoca mudanças nos valores de implicação direta, sinalizando que esse tipo de operação diminui a vulnerabilidade da empresa. Em outras palavras, significa uma rígida obrigação de se obter alta lucratividade para suportar uma alavancagem é suavizada via securitização.

5. As estatísticas baseadas em dados de balanço sinalizam que a securitização de ativos tem impacto positivo, diminuindo o desvio padrão e a média de alavancagem e endividamento total e aumentando a lucratividade econômica e financeira.

Em resumo, somente as relações entre 0 índice de endividamento total e o beta apresentaram nível de confiança abaixo de $95 \%$ de implicação fuzzy e, em algumas relações, esta implicação tem intensidade baixa, mas tem nível de confiança acima de $95 \%$. Isto sinaliza que essas relações, com nível de confiança acima de $95 \%$, existem, embora sejam de baixa intensidade. Logo, para as análises via implicação fuzzy, as quatro hipóteses são verdadeiras, ajudando a diminuir as dúvidas que ainda restavam das análises de regressão e de correlação desta pesquisa.

\section{7 - Análise do comportamento do rating de crédito após a securitização de ativos}

O objetivo secundário desta pesquisa é determinar se a utilização da securitização de ativos, têm em média, influência positiva sobre os indicadores financeiros utilizados na classificação de rating de crédito das empresas, ou seja, neste trabalho refere-se a indicadores financeiros de classificação de rating (IFCR).

Os indicadores financeiros analisados constam no quadro-11 da seção 4.2 e, são referentes ao período de 2000 a 2005 , de empresas que utilizaram a securitização de ativos nesse mesmo período e, fez-se uma análise comparativa antes e após o início da securitização. 
O critério utilizado foi comparar as médias dos indicadores analisados antes da securitização e após o início da securitização, por todo o período de 2000 a 2005.

Os dados utilizados na análise são apresentados na tabela a seguir:

Tabela 39 - Índicadores financeiros de classificação de rating (IFCR)

\begin{tabular}{|c|c|c|c|c|c|c|c|}
\hline EmpresalAno & 2000 & 2001 & 2002 & 2003 & 2004 & 2005 & MEDIA \\
\hline AcesitaPN & $-13 \%$ & $24 \%$ & $10 \%$ & $-24 \%$ & $11 \%$ & $20 \%$ & $5 \%$ \\
\hline AracnzON & $10 \%$ & $0 \%$ & $-6 \%$ & $29 \%$ & $-10 \%$ & $11 \%$ & $6 \%$ \\
\hline BraskemON & $4 \%$ & $10 \%$ & $1 \%$ & $11 \%$ & $-2 \%$ & $10 \%$ & $6 \%$ \\
\hline Cataguazes & $4 \%$ & $8 \%$ & $-14 \%$ & $-17 \%$ & $16 \%$ & $-8 \%$ & $-2 \%$ \\
\hline CespON & $12 \%$ & $0 \%$ & $0 \%$ & $2 \%$ & $0 \%$ & $-1 \%$ & $2 \%$ \\
\hline Cia Brasileira de Distribução & $21 \%$ & $0 \%$ & $5 \%$ & $5 \%$ & $3 \%$ & $4 \%$ & $6 \%$ \\
\hline Copesu ON & $3 \%$ & $6 \%$ & $-4 \%$ & $-28 \%$ & $75 \%$ & $49 \%$ & $17 \%$ \\
\hline CPFL Piratininga ON & ND & ND & $-64 \%$ & $11 \%$ & $-5 \%$ & $10 \%$ & $-12 \%$ \\
\hline Gradiente ON & $-5 \%$ & $-239 \% *$ & $-50 \%$ & $-26 \%$ & $-14 \%$ & $-15 \%$ & $-22 \%$ \\
\hline Perdigao ON & $-40 \%$ & $-13 \%$ & $-468 \% *$ & $3 \%$ & $-38 \%$ & $-6 \%$ & $-19 \%$ \\
\hline PetroflexON & $-19 \%$ & $-14 \%$ & $-14 \%$ & $-11 \%$ & $4 \%$ & $11 \%$ & $-7 \%$ \\
\hline Sadia SAON & $6 \%$ & $-25 \%$ & $-8 \%$ & $-2 \%$ & $33 \%$ & $6 \%$ & $1 \%$ \\
\hline Sansuy & $-2 \%$ & $10 \%$ & $1 \%$ & $-6 \%$ & $-1 \%$ & $0 \%$ & $0 \%$ \\
\hline CST & $58 \%$ & $-29 \%$ & $17 \%$ & $81 \%$ * & $152 \%$ * & $149 \%$ * & $15 \%$ \\
\hline Teleforica BDR & $-15 \%$ & $1 \%$ & $13 \%$ & $5 \%$ & $14 \%$ & ND & $3 \%$ \\
\hline Telesp Cel Part PN & $251 \%$ * & $-19 \%$ & $9 \%$ & $16 \%$ & $-47 \%$ & $-14 \%$ & $-11 \%$ \\
\hline Trikem & $24 \%$ & $28 \%$ & $45 \%$ & $35 \%$ & $51 \%$ & $39 \%$ & $37 \%$ \\
\hline Vale RoDoce ON & $12 \%$ & $13 \%$ & $-9 \%$ & $41 \%$ & $32 \%$ & $24 \%$ & $19 \%$ \\
\hline
\end{tabular}

\section{Fonte: Elaborada pelo Autor}

Quando a securitização teve início num segundo semestre, considerou-se o ano seguinte para a marcação. (N/D não disponível)

O conjunto de dados foi dividido em duas amostras:

- Amostra 1: sem securitização;

- Amostra 2: após o início da securitização. 
Considerando-se uma distribuição normal para ambas as amostras, o objetivo é comparar as médias dos índices financeiros da amostra 1 e 2 e verificar se há diferença estatística entre elas.

A proporção da amostra 2 em relação à amostra 1, vai aumentando ano a ano. Desta forma, uma diferença entre as médias das duas amostras, poderia ser decorrente da evolução natural dos indicadores financeiros durante o período analisado. Por este motivo, procurou-se avaliar se, neste período, existiu variação das médias dos índices.

Para tanto, utilizou-se a análise de variância (ANOVA).

Antes, porém, excluíu-se da análise, os valores que ficaram fora de um intervalo de $99 \%(2,33 \sigma)$ da distribuição dos dados, conforme a tabela 40 a seguir. Os indicadores que não foram considerados para as análises estão marcados com asterisco na tabela 39 anterior.

Tabela 40 - Média, desvio padrão e intervalo de 99\% da distribuição dos indicadores financeiros

\begin{tabular}{|c|c|c|c|c|c|c|}
\cline { 2 - 7 } \multicolumn{1}{c|}{} & $\mathbf{2 0 0 0}$ & $\mathbf{2 0 0 1}$ & $\mathbf{2 0 0 2}$ & $\mathbf{2 0 0 3}$ & $\mathbf{2 0 0 4}$ & $\mathbf{2 0 0 5}$ \\
\hline MÉDIA & $18 \%$ & $-14 \%$ & $-30 \%$ & $7 \%$ & $15 \%$ & $17 \%$ \\
\hline DESVIO & $64 \%$ & $60 \%$ & $112 \%$ & $27 \%$ & $45 \%$ & $38 \%$ \\
\hline$+\mathbf{2 , 3 3} \sigma$ & $166 \%$ & $126 \%$ & $231 \%$ & $70 \%$ & $119 \%$ & $106 \%$ \\
\hline$-\mathbf{2 , 3 3} \sigma$ & $-130 \%$ & $-154 \%$ & $-290 \%$ & $-56 \%$ & $-89 \%$ & $-72 \%$ \\
\hline
\end{tabular}

Fonte: Elaborada pelo Autor

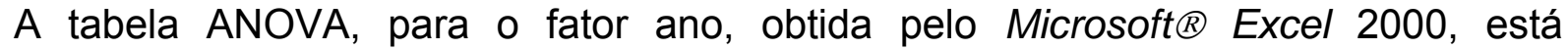
demonstrada na tabela 41 a seguir. 
Tabela 41 - Tabela ANOVA com fator ano

Anova: fator único

RESUMO

\begin{tabular}{ccccc}
\hline Ano & Contagem & Soma & Média & Variância \\
\hline 2000 & 16 & $60 \%$ & $4 \%$ & $5 \%$ \\
2001 & 16 & $-1 \%$ & $0 \%$ & $3 \%$ \\
2002 & 17 & $-70 \%$ & $-4 \%$ & $6 \%$ \\
2003 & 17 & $43 \%$ & $3 \%$ & $4 \%$ \\
2004 & 17 & $123 \%$ & $7 \%$ & $9 \%$ \\
2005 & 16 & $140 \%$ & $9 \%$ & $3 \%$ \\
\hline
\end{tabular}

ANOVA

\begin{tabular}{lcccccc}
\hline Fonte da variação & $S Q$ & $g l$ & $M Q$ & $F$ & valor-P & F crítico \\
\hline Entre grupos & $19 \%$ & 5 & $4 \%$ & 0,749 & 0,589 & 2,31 \\
Dentro dos grupos & $461 \%$ & 93 & $5 \%$ & & & \\
Total & & & & & & \\
\hline
\end{tabular}

Fonte: Elaborada pelo Autor

A hipótese

$$
\mathrm{H}_{0}: \mu_{2000}=\mu_{2001}=\mu_{2002}=\mu_{2003}=\mu_{2004}=\mu_{2005}
$$

Essa hipótese pode ser testada usando-se os valores da estatística F. Como o valor de $\mathrm{F}(0,749)$ é menor do que o $\mathrm{F}_{\text {crítico }}(2,31)$ não rejeita-se $\mathrm{H}_{0}$, com uma probabilidade de $95 \%$.

Com isso, não é possível afirmar que por influência do passar dos anos, há variação nos indicadores financeiros de classificação de rating (IFCR) das empresas analisadas. 
Por essa razão, houve nessecidade de continuidade nas análises, calculando a média e o desvio dos índices antes da securitização (amostra1) e a média e desvio dos índices após o início da securitização (amostra 2). Esses resultados estão demonstrados na tabela 42 a seguir.

Tabela 42 - Média, desvio padrão e tamanho da amostragem das duas amostra analisadas

\begin{tabular}{|l|c|c|}
\hline & $\begin{array}{c}\text { Sem } \\
\text { securitização } \\
\text { (amostra 1) }\end{array}$ & $\begin{array}{c}\text { Após início da } \\
\text { securitização } \\
\text { (amostra 2) }\end{array}$ \\
\hline Média, $\mu$ & $-3 \%$ & $12 \%$ \\
\hline Desvio Padrão, $\sigma$ & $18 \%$ & $25 \%$ \\
\hline Tamanho da amostra, $n$ & 60 & 39 \\
\hline
\end{tabular}

Fonte: Elaborada pelo Autor

Com base nos resultados apresentados, deseja-se testar as hipóteses:

$$
\begin{aligned}
& \mathrm{H}_{0}: \mu_{1}=\mu_{2} \\
& \mathrm{H}_{1}: \mu_{2}>\mu_{1}
\end{aligned}
$$

Ao fazer um teste de diferença entre médias de duas populações distintas, deve-se inicialmente fazer um teste para verificar se as variâncias são iguais ou diferentes. Utiliza-se para tanto, o teste $\mathrm{F}$.

Teste F:

$\mathrm{H}_{0}: \sigma^{2}{ }_{1}=\sigma^{2}{ }_{2}$

$\mathrm{H}_{1}: \sigma^{2}{ }_{1} \neq \sigma^{2}{ }_{2}$

Logo, a variável de teste é: 
$F_{n 2-1, n 1-1}=\sigma_{2}^{2} / \sigma_{1}^{2} \rightarrow F_{38,59}=1,93$ e $F_{\text {critico }}(5 \%)=1,76$ (obtido pelo Microsoft $\AA$ Excel

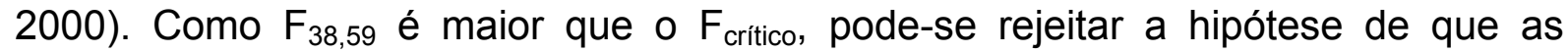
variâncias populacionais, desconhecidas, são iguais, com uma chance de erro de $5 \%$.

A variável estatística para diferença entre médias, neste caso, aproxima-se de uma distribuição t de Student, com número de graus de liberdade dado aproximadamente por:

$$
\mathrm{v}=\frac{\left(\mathrm{w}_{1}+\mathrm{w}_{2}\right)^{2}}{\frac{\mathrm{w}_{1}^{2}}{\mathrm{n}_{1}-1}+\frac{\mathrm{w}_{2}^{2}}{\mathrm{n}_{2}-1}}, \text { onde } \quad \mathrm{w}_{\mathrm{i}}=\frac{\sigma_{\mathrm{i}}^{2}}{\mathrm{n}_{\mathrm{i}}}
$$

em que:

$$
\begin{aligned}
& \mathrm{w}_{1}=0,000547 \\
& \mathrm{n}_{1}=60 \\
& \mathrm{w}_{2}=0,001575 \\
& \mathrm{n}_{1}=39
\end{aligned}
$$

Portanto, obtém-se:

$$
v=64 . \text { e a variável } t_{0}=\frac{\mu_{2}-\mu_{1}}{\sqrt{w_{1}+w_{2}}}=3,22
$$

Com uso do Microsoft ${ }^{\circ}$ Excel 2000, tem-se que a Região Crítica, RC $\left.=\right] 1,67 ;+\infty[$, ao nível de $5 \%$ de significância.

Como $t_{0} \in R C$, rejeita-se a hipótese $H_{0}$, ou seja, existe evidência de que a securitização de ativos resulta em melhores índices financeiros de rating, com 95\% de confiança. 
Esse mesmo teste foi repetido sem considerar os dados da empresa Trikem, visto que a média dos índices, no período analisado, é consideravelmente superior às demais empresas, conforme pode-se observar na Tabela 39, além da securitização ter iniciado no ano de 2000. Desta forma, os dados dessa empresa poderiam estar distorcendo o resultado obtido anteriormente.

Têm-se, com isso, novos valores para as amostras, conforme a tabela 43 a seguir:

Tabela 43 - Média, desvio padrão e tamanho da amostragem das duas amostras analisadas

\begin{tabular}{|l|c|c|}
\hline & $\begin{array}{c}\text { Sem } \\
\text { securitização } \\
\text { (amostra 1) }\end{array}$ & $\begin{array}{c}\text { Após início da Securitização } \\
\text { (parcial) } \\
\text { (amostra 3) }\end{array}$ \\
\hline Média, $\mu$ & $-3 \%$ & $7 \%$ \\
\hline Desvio Padrão, $\sigma$ & $18 \%$ & $24 \%$ \\
\hline Tamanho da amostra, $n$ & 60 & 33 \\
\hline
\end{tabular}

Fonte: Elaborada pelo Autor

Teste F:

$$
\begin{aligned}
& H_{0}: \sigma^{2}{ }_{1}=\sigma^{2}{ }_{3} \\
& H_{1}: \sigma^{2}{ }_{1} \neq \sigma^{2}{ }_{3}
\end{aligned}
$$

A variável de teste é:

$F_{n 2-1, n 1-1}=\sigma^{2}{ }_{2} / \sigma^{2}{ }_{1} \rightarrow F_{32,59}=1,75$ e $F_{\text {crítico }}(5 \%)=1,80$. Como $F_{32,59}$ é menor que o

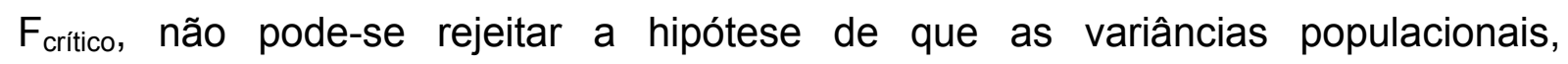
desconhecidas, são iguais. Considera-se, então, com uma probabilidade de $95 \%$ de que as variâncias das duas populações são iguais. 
Com relação às médias, deseja-se testar as hipóteses:

$$
\begin{aligned}
& \mathrm{H}_{0}: \mu_{1}=\mu_{3} \\
& \mathrm{H}_{1}: \mu_{3}>\mu_{1}
\end{aligned}
$$

Para este caso, pode-se combinar $\sigma^{2}{ }_{1}$ e $\sigma^{2}{ }_{3}$, para se obter um estimador comum de $\sigma^{2}$ da população:

$$
\sigma_{\mathrm{p}}{ }^{2}=\frac{\left(\mathrm{n}_{1}-1\right) \sigma_{1}{ }^{2}+\left(\mathrm{n}_{3}-1\right) \sigma_{2}{ }^{2}}{\mathrm{n}_{1}+\mathrm{n}_{3}-2}=\frac{(60-1) 0,18^{2}+(33-1) 0,24^{2}}{60+33-2}=4 \%
$$

De acordo com a teoria estatística:

$$
\mathrm{t}_{0}=\frac{\mu_{3}-\mu_{1}}{\sigma_{\mathrm{p}} \sqrt{1 / \mathrm{n}_{1}+1 / \mathrm{n}_{3}}}
$$

Assim, têm-se uma distribuição t de Student com $\left(n_{1}+n_{3}-2\right)$ graus de liberdade sob a hipótese $\mathrm{H}_{0}$.

$$
\left.\mathrm{t}_{0}=\frac{0,07+0,03}{0,20 \sqrt{1 / 60+1 / 33}}=2,33 \text { e } \mathrm{RC}=\right] 1,66 ;+\infty[
$$


Novamente, tem-se $t_{0} \in R C$ e, com isso, rejeita-se a hipótese $H_{0}$ a $5 \%$ de significância, ou seja, existe evidência de que os indicadores financeiros de classificação de rating (IFCR) após o início da securitização, no período analisado, são melhores do que os mesmos indicadores financeiros antes da securitização.

Pode-se ainda adotar uma classificação de rating para os valores dos indicadores financeiros obtidos, conforme a tabela 44 a seguir.

Tabela 44 - Indicadores financeiros por classificação de título

\begin{tabular}{|c|c|c|c|c|c|c|}
\hline AAA & AA & A & BBB & BB & B & CCC \\
\hline $41 \%$ & $22 \%$ & $17 \%$ & $6 \%$ & $1 \%$ & $-4 \%$ & $-25 \%$ \\
\hline
\end{tabular}

\section{Fonte: Standard \& Poors}

De acordo com a classificação da tabela 44 anterior e, os valores médios obtidos para as três amostras, têm-se:

Tabela 45 - Comportamento do rating de crédito

\begin{tabular}{|l|c|}
\hline \multicolumn{1}{|c|}{ Amostra } & Classificação Média \\
\hline Antes da securitização & B \\
\hline Após o início da securitização & BBB \\
\hline Após o início da securitização (parcial) & BBB \\
\hline
\end{tabular}

Fonte: Elaborada pelo Autor

Conforme os resultados obtidos nessa tabela 45, para as empresas analisadas no período de 2000 a 2005, há indicação que, após o início da securitização de ativos, os índices financeiros de rating são alterados, provocando uma melhora na classificação média dos ratings de crédito.

Assim, os resultados apresentados, confirmam a hipótese 5, ou seja, é possível melhorar o rating de crédito das empresas que realizam operações de securitização de ativos. 
Portanto, de acordo com os resultados obtidos, pode-se concluir que a securitização de ativos poderá provocar impacto positivo nos indicadores financeiros, ou seja, as variáveis analisadas, após o início da securitização, terão seus índices melhorados. Isso representará a diminuição da alavancagem financeira e diminuição do endividamento bancário, por exemplo. Consequentemente, de acordo com a mensuração dos novos índices, após o início da securitização, a classificação do rating de crédito poderá ser elevado, ou seja, o rating de crédito subirá de posição, indicando a diminuição do risco de crédito (default) da empresa que realizou a securitização de ativos.

A partir disso, a empresa beneficiar-se-á em relação ao custo dos novos empréstimos ou novas emissões de títulos de dívida, pois tanto os bancos (fornecedores de empréstimos), quanto os investidores (compradores de títulos), exigirão taxas de retorno proporcionais à classificação do risco de crédito. Neste caso, essas taxas serão menores, pois o risco de crédito (rating) melhorou. Isso é confirmado de acordo com Altman et al. (2000, p.115) "a securitização leva a uma estrutura de custos mais baixos". 


\section{CAPÍTULO 6 - CONSIDERAÇÕES FINAIS}

"O que se conhece, claramente se enuncia".

Nicolas Boileau (Universidade de Sorbone)

O objetivo principal desta pesquisa foi identificar, o impacto da securitização de ativos nos indicadores financeiros e beta das empresas. Para tanto, foram realizados diversos testes de associação e regressões, simples e múltiplas, além da lógica fuzzy, utilizando quatro grupos de indicadores financeiros:

- Beta de mercado das ações, referente às empresas que realizaram securitização de ativos;

- Beta alavancado;

- Graus de alavancagem total, financeira e operacional (GAT, GAF e GAO) e

- Indicadores de lucratividade financeira e econômica.

Tais testes foram realizados utilizando diversos indicadores de resultado das empresas analisadas e alguns ajustes foram necessários para a padronização dos dados, bem como, a normalização das variáveis testadas para obter melhores associações entre os resultados. Para a maioria dos casos testados, as correlações encontradas tiveram satisfatória significância estatística e, apontam no sentido de que a securitização de ativos provoca impactos positivos nos indicadores financeiros e, consequentemente, melhora o rating de crédito das empresas que realizam a securitização de ativos.

Em relação ao rating de crédito, observou-se que nesse período e o grupo de empresas analisadas, a securitização de ativos estabeleceu melhora significante nos indicadores financeiros testados estatisticamente e, consequentemente, a elevação do rating de crédito médio das empresas analisadas. 
De acordo com os princípios dos fundamentos da administração financeira formulados por diversos autores, quanto mais a empresa utiliza empréstimos bancários ou emissão de títulos de dívida, maiores são seus riscos financeiros e mais elevada será a taxa de retorno exigida pelos acionistas sobre o seu capital próprio. Em função disso, essa situação é previsível na teoria de finanças e, a securitização de ativos pode ser uma alternativa para substituir esse endividamento na forma tradicional que as empresas utilizam. Logo, a securitização vem tornandose uma porta de acesso ao mercado de capitais para qualquer empresa que necessite de crédito e possua recebíveis.

Os indicadores analisados e associados ao endividamento, apresentaram satisfatória relação com o beta de mercado das ações das empresas, mas $\mathrm{R}^{2}$ ajustados baixos. Destaca-se o grau de alavancagem financeira (GAF) que demonstrou capacidade de explicar uma parcela significativa da variação dos betas das empresas.

Essas evidências são percebidas no mercado de capitais brasileiro, onde o risco conjuntural está mais associado à estrutura de custos financeiros em função da estrutura de capital e, em menor dimensão, aos custos operacionais e indicam que os administradores financeiros estão mais preocupados em reduzir os custos onerosos do endividamento do que reduzir os custos envolvidos da alavancagem operacional.

Entretanto, os graus de alavancagem financeira e operacional (GAF e GAO) das empresas utilizadas nessa pesquisa e, os betas de mercado, mas $R^{2}$ ajustados baixos, apresentaram de forma geral, satisfatória significância estatística. De certa forma coerente, pois supõe-se que empresas com custos fixos operacionais mais elevados, provocados pela alavancagem operacional, apresentem maior volatilidade de fluxos de caixa e consequentemente, maiores riscos associados a variações conjunturais de demanda e de preços. Essas variações foram, de alguma forma, capturadas pelas relações estatísticas da análise de regressão desse trabalho.

A teoria de finanças indica que a variação do lucro líquido da empresa está mais associada ao grau de alavancagem operacional (GAO), porém é percebido que o beta de mercado das ações das empresas, é mais sensível à estrutura de capital e 
indica que os administradores financeiros esforçam-se em reduzir o custo de capital de terceiros das suas empresas e consequentemente, provocar a redução do beta de mercado das ações.

A partir dos resultados encontrados o objetivo secundário de examinar o comportamento do rating de crédito das empresas, após a realização da operação de securitização de ativos, foi analisado. Esse objetivo é secundário, em virtude do rating de crédito ser resultado do comportamento dos indicadores financeiros. Logo, em uma melhora da relação dos indicadores financeiros após a securitização de ativos, é previsível supor que o rating de crédito possa sofrer alterações positivas (melhora do rating).

De acordo com a investigação dessa pesquisa, foram encontradas algumas evidências que permitem estabelecer algumas características diferentes entre as fontes de financiamento tradicionais, ou seja, empréstimos bancários e títulos de dívida, e a securitização de ativos, a saber:

- Empréstimos Bancários: qualquer tipo de empresa, sociedade anônima (S/A) ou sociedade limitada (LTDA), pode obter empréstimos bancários; oferta de crédito depende da capacidade de endividamento e do grau de alavacagem financeira da empresa; os prazos desse tipo de empréstimo, geralmente são de curto e médio prazos (até 1 ano); esses empréstimos podem necessitar de garantias reais ou fidejussórias; o risco de crédito é concentrado na empresa que captou o empréstimo e nas garantias oferecidas; baixo custo de estruturação (tarifas bancárias); o custo ou taxa do empréstimo de acordo com o risco da empresa e garantias oferecidas; a classificação do risco de crédito (rating) de acordo com os fundamentos econômico-financeiros da empresa que realizou o empréstimo bancário; negativo impacto dos indicadores financeiros (aumenta o grau de alavancagem financeira e índice de endividamento bancário); oferta de crédito dependente dos bancos; fonte de recursos no mercado doméstico brasileiro e operações de empréstimos são realizadas fora do mercado de capitais;

- Títulos de Dívida: somente as empresas classificadas como sociedade anônima (S/A) podem realizar emissões de títulos de dívida; oferta de crédito 
depende da capacidade de endividamento e grau de alavancagem financeira da empresa emissora do título de dívida; os prazos dos títulos podem ser de médio e longo prazos (igual ou superior a 1 ano); os títulos de dívida podem apresentar garantias reais ou fidejussórias; o risco de crédito está concentrado na empresa emissora do título de dívida e nas garantias oferecidas; os elevados custos iniciais e custos correntes referentes à estruturação de emissão do título de dívida, ou seja, (comissões de estruturação e distribuição, taxas de registros, despesas com advogados, despesas de marketing entre outras); o custo ou taxa de emissão do título de dívida estabelecido de acordo com a classificação do risco de crédito (rating) da empresa emissora do título; a emissão do título de dívida impacta negativamente os indicadores financeiros (aumenta o grau de alavancagem financeira e índice de endividamento); a oferta de crédito é dependente dos investidores institucionais (basicamente os fundos de pensão, fundos de investimentos e seguradoras); esse tipo de fonte de recurso é obtido no mercado doméstico brasileiro, bem como poderá ser acessado o mercado internacional e essas emissões de títulos de dívida são realizadas no mercado de capitais.

- Securitização de Ativos: qualquer tipo de empresa classificada como sociedade anônima (S/A), ou mesmo sociedade limitada (LTDA) pode realizar operações de securitização de ativos; a oferta de crédito é dependente da qualidade dos ativos de crédito que a empresa originadora mantenha no seu contas a receber; os prazos da securitização de ativos são de longo prazo (geralmente superior a 3 anos); a estrutura da securitização de ativos segrega o risco do originador, ou seja, o risco de crédito (default) será concentrado nos ativos (recebíveis), bem como no sobre-colateral (over-collateral) oferecidos em garantia para eventual inadimplência; esse tipo de operação possui elevados custos iniciais e custos correntes referentes à estruturação da securitização, ou seja, (comissões de estruturação e distribuição, taxas de registros, despesas com advogados, despesas de marketing entre outros); o custo ou taxa de emissão do título securitizado será de acordo com a classificação do risco de crédito (rating), da estrutura da securitização; a venda de recebíveis impacta positivamente os indicadores financeiros 
(diminuiu o grau de alavancagem financeira e índice de endividamento); a oferta de crédito é dependente dos investidores institucionais (basicamente os fundos de pensão, fundos de investimentos e seguradoras) e esse tipo de operação estruturada é realizada no mercado de capitais doméstico brasileiro, bem como acessar o mercado de capitais internacional.

Em síntese, apesar desse trabalho ter identificado a existência de relações de satisfatória significância estatística entre os graus de alavancagem financeira, operacional (GAF e GAO) e o beta das empresas, mas $\mathrm{R}^{2}$ ajustados baixos, com a securitização de ativos, esse tema permanece aberto para novas pesquisas com a utilização de outras variáveis e ainda requer aperfeiçoamentos que permitam testes mais rigorosos, fornecendo mais informações a respeito do impacto que a securitização de ativos possa ter sobre o comportamento dos indicadores financeiros e o beta de mercado das ações das empresas.

Assim, acredita-se que o tema é de elevada importância, pois a securitização de ativos é o mais novo instrumento financeiro de captação de recursos e outros desdobramentos devem ser investigados. Espera-se que este trabalho tenha contribuido para ampliar o conhecimento científico das relações entre as decisões do conjunto de fontes de financiamento disponíveis no mercado de capitais e das inovações financeiras, por meio da securitização de ativos, e que possa servir como referência para estudos posteriores em um futuro próximo. 


\section{REFERÊNCIAS BIBLIOGRÁFICAS}

ALTMAN, E.I. - A Further Empirical Investigation of the Bankruptcy Cost Question. Journal of Finance, Chicago: American Finance Association, September, 1984.

ALTMAN, E., CAOUETTE, J.B., NARAYANAN, P. Gestão de Riscos de Crédito: o próximo grande desafio financeiro. Rio de Janeiro: Qualitymark, 2000.

ANTUNES, Jerônimo. Lógica Nebulosa (Fuzzy Logic) para Avaliar Riscos na Auditoria. Revista de Contabilidade e Finanças, Departamento de Contabilidade e Atuáruia, FEA-USP, Ano XVII, vol.3, setembro, 2006.

ASCARELLI, Tullio - Teoria Geral dos Títulos de Crédito. São Paulo, Ed. Saraiva, 1943.

ASSAF, Alexandre, Neto. Mercado Financeiro. São Paulo, 6a Edição, Ed. Atlas, 2001.

ASSAF, Alexandre, Neto. Estrutura e Análise de Balanços. São Paulo, $7^{a}$ Edição, Ed. Atlas, 2002.

ASSAF, Alexandre, Neto. Finanças Corporativas e Valor, São Paulo, Ed. Atlas, 2003.

ASSET-BACKED ALERT, The Weekly Update on Worldwide Securitization - site: www.abalert.com, 2006.

BARRETO FILHO, Oscar. Regime Jurídico das Sociedades de Investimento. São Paulo: Max Limonad, 1975.

BENZIN, Arne;TRUCK, Stefan; RACHEV, Svetlozar T. - Credit Risk - Measurement, Evaluation and Management - Approaches to Credit Risk in the New Basel Capital Accord - Physica-Verlag Heidelberg, 2003.

BID - Bank Interamerican for Development - Unlocking Credit: The Quest for Deep and Stable Bank Lending - New York, Washington, D.C. 20577, 2004.

BIS - Bank for International Settlement - Documento de Apoio ao Novo Acordo de Capital da Basiléia - Securitização de Ativos - Febraban e Ernst \& Young, 2001.

BORGES, Luiz Fernando Xavier. - Securitização como parte da Segregação de Risco. Artigo da Revista do BNDES, vol.6, n 12, p.123-136, dezembro, 1999.

BREALEY, Richard A., MYERS, Stewart C. Princípios de Finanças Empresariais. $5^{\text {a }}$ ed. Portugal: McGraw-Hill, 1998.

BREALEY, Richard A., MYERS, Stewart C. - On Corporate Finance: Financing and Risk Management. McGraw-Hill, 2003. 
BRIGHAM, Eugene F.; HOUSTON, Joel F. Fundamentos da Moderna Administração Financeira. Ed.Campus, 1999.

BRIGHAM, Eugene F.; WESTON, J.Fred. - Fundamentos da Administração Financeira. Makron Books, 2000.

COSTA, Davi Rogério de Moura - Rating de Cooperativas Agropecuárias: Uma Contribuição Metodológica - Dissertação apresentada à Escola Superior de Agricultura Luiz de Queiroz, da Universidade de São Paulo - Piracicaba - SP, 2005.

COPELAND, T.E. e WESTON, J.F. Financial Theory and Corporate Policy. 3 ed. EUA: Addison Weley Publishing Company, 1988.

COPELAND, Tom; KOLLER, Tim; MURRIN, Jack, - Avaliação de Empresas Valuation: Calculando e Gerenciando o Valor das Empresas, Makron, 2002.

COUTURIER, A.; FIOLEAU, B. - Debt level and company efficiency: independence or implication? An evaluation of fuzzy implications. European Journal of Economic and Social Systems $14 \mathrm{~N}^{\circ} 117-25,2000$.

COVELLO, Sérgio Carlos - Contratos Bancários, Editora LEUD, São Paulo, 1999.

CHERUBIN, Umberto - Fuzzy measures and asset prices: accounting for information ambiguity. Applied Mathematical Finance 4, 135-149, 1997.

CHINEN, Emerson Norio. Securitização de Recebíveis. Projeto de Dissertação de Mestrado, Departamento de Direito Comercial da Faculdade de Direito da USP, 2002.

CUMMINS, J.David - Securitization of Life Insurance Assets and Liabilities - The Wharton School, 2004.

CROUHY, Michel; GALAI, Dan; MARK, Robert - Gerenciamento de Risco - Uma Visão Integrada dos Riscos de Crédito, Operacional e de Mercado - Qualitymark série Serasa, 2004.

CRUZ, Marcelo - Modeling, Measuring and Hedging Operational Risk. John Wilwy \& Sons, 2002.

CVM - Comissão de Valores Mobiliários - Registro de Ofertas Públicas - site: www.cvm.gov.br, 2006.

DAMODARAN, Aswath, - Avaliação de Investimentos: Ferramentas e Técnicas para Determinação do Valor de Qualquer Ativo, Qualitymark, 1997.

DAMODARAN, Aswat. - Corporate Finance. John Wiley \& Sons, Inc., 2001.

DAMODARAN, Aswat. - Finanças Corporativas Aplicadas - Manual do Usuário São Paulo: Editora Bookman, 2002. 
DAMODARAN, Aswat. - Finanças Corporativas, Teoria e Prática. $2^{a}$ ed. São Paulo: Editora Bookman, 2004.

DE ANGELO, H.; MASULIS, R.- Optimal capital structure under corporate and personal taxation. J. Financial Economics, March, pp. 3-30, 1980.

DEINICHENKO V.; BIKESHEVA G.; and BORISOV A. - Fuzzy approach in economic modelling of economics of growth. In P. Ein-Dor (Ed.), Artificial Intelligence in Economics and Management. Norwell, Massachusetts: Kluwer Academic Publishers, pp. 155-173, 1996.

DEMO, Pedro. - Metodologia Científica Em Ciências Sociais, $3^{a}$ ed., Atlas, 1995.

DERMINE, Jean; BISSADA, Yousssef F. - Gerenciamento de Ativos e de Passivos Um Guia para Criação de Valor e Controle de Riscos - Editora Atlas, 2005.

DUBOIS, M. - Les déterminants de la structure financière : le cas des grandes entreprises françaises. Finance, juin, pp. 41-70. France, 1985.

DURAND, D. Cost of Debt and Equity Funds for Business: Trends and Problems of Measurement. In: Conference on Research on Business Finance. New York: National Bureau of Economic Research, 1952.

ELTON, Edwin J.;GRUBER, Martin J.; BROWN, Stephen J.; GOETZMANN, William N. - Modern Portfolio Theory and Investment Analysis. John Wiley \& Sons, Inc., 2003.

ESF - SECURITIZATION DATA REPORT, -The Bond Market Association and European Securitization Fórum - Autumm, 2001.

FABOZZI, F. Mercados, Análise e Estratégias de Bônus (Títulos de Renda Fixa). $3^{a}$ ed. Rio de Janeiro: Qualitymark, 2000.

FAMÁ, Rubens; BARROS, Lucas Ayres B. de; SILVEIRA, Alexandre Di Miceli; A Estrutura de Capital é Relevante? Novas Evidências a Partir de Dados NorteAmericanos e Latino-Americanos, Caderno de Pesquisas em Administração, São Paulo, v.08, n², Abril/Junho, 2001.

FAMÁ, Rubens; GRAVA, J. Willian - Liquidez e a Teoria dos Elementos Causadores de Insolvência - Caderno de Pesquisas em Administração, Volume 1, N 12, 2 bimestre, 2000.

FNMA - Federal National Mortgage Association -Fannie Mae, For Fannie Mae's Investors and Dealers - Fundingnotes - November/December, 2006.

FERREIRA, Maria Aparecida de Aguiar. Psicologia Aplicada a Administração Teoria Critica e a Questão Ética nas Organizações. Excellus, 1992.

FERREIRA, José Antonio Stark - Finanças Corporativas - Conceitos e Aplicações Editora Pearson Prentice Hall, 2005. 
FINANCIAL TIMES. - London Business School. Makron Books, 1997.

FITCH IBCA, DUFF \& PHELPS - Corporate Rating Methodology - Criteria Report May, 2001.

FITCH IBCA, DUFF \& PHELPS - Use of Insurance Policies as Credit Enhancement in Structured Finance - Special Report; June, 2001.

FITCH IBCA, DUFF \& PHELPS - Brazilian Bankruptcy Law and Future Flow Securitisation - International Special Report; August, 2000.

FITCH RATINGS - Finanças Estruturadas - Securitização de Crédito no Brasil, Metodologia para Rating de Cartão de Crédito, Crédito ao Consumo, Financiamento de Veículos e Recebíveis Imobiliários - Relatório de Critério: Dezembro, 2002.

FITCH RATINGS - Default Correlation and its Effect on Portfolios of Credit Risk, Structured Finance, Credit Products Special Report - February, 2003.

FITCH RATINGS - Structured Finance - Latin American Structured Finance 2002 Year in Review and Outlook: March, 2003.

FITCH RATINGS - Structured Finance - A Road to Rating Auto Loan-Backed Securitizations - Asset-Backed Criteria Report: March, 2002.

FITCH RATINGS - Structured Finance - Securitization in South Africa-A Revolution for Local Funding - Special Report: March, 2003.

FITCH RATINGS - Medidas de Fluxo de Caixa na Análise Corporativa - Relatório de Metodologia: Julho, 2005.

FITCH RATINGS - Securitization in Emerging Markets: Preparing for the Rating Process - Special Report: January, 2004.

FITCH RATINGS - Metodologia de Securitização de Fluxos Futuros de Recebíveis no Brasil - Relatório de Metodologia: Fevereiro, 2005.

FITCH RATINGS - Securitização de Ativos Existentes no Brasil - Relatório de Metodologia: Julho, 2005.

FLEURIET, Michel. - A Arte e a Ciência das Finanças - Uma Introdução ao Mercado Financeiro: Campus, 2004.

FONSECA, Jairo S., MARTINS, Gilberto .A. - Curso de Estatística - $6^{a}$ edição, Editora Atlas, 1996.

GAGGINI, Fernando S. - Securitização de Recebíveis. Livraria e Editora Universitária de Direito, 2003.

GARCIA, Susana Blanco; MOLINA, Pedro Carvajal - Evolucion Del Processo de Titulizacion em Espana: Universidad Complutense de Madrid, Espana, 2001. 
GARROD, Neil; MRAMOR, Dusan. On Accounting Flows and Systematic Risk. Working Paper, 2000.

GNMA - Government National Mortgage Association- Gennie Mae, 2006.

GONZALES, G. M. - Considerations for the development of a mortgage market in Peru". Housing Finance International, vol. 15, n. 2, p. 45-48 : Chicago, 2000.

GORTON, Gary; SOULELES, Nicholas S.; Special Purpose Vehicles and Securitization. The Warton School - University Pennsylvania and NBER, september, 2005.

GRAS R. - L'implication statistique, Collection Associée à Recherches en Didactique des Mathématiques", La Pensée Sauvage, Grenoble, 1996.

GRAS, R.; BRIAND, H.; PETER, P.; PHILIPPE, J. - Implicative statistical analysis. Proceedings of International Congress I.F.C.S., 96, Kobé, Springer-Verlag, Tokyo: 412-419, 1997.

GUYON, C. - La fonction financière dans l'entreprise. Tome 1, 3e édition, Masson, Paris, 1992.

HAMADA, R. S. The Effect of the Firm's Capital Structure on the Systematic Risk of Common Stock. Journal of Finance, vol. 27, issue 2, p. 435-452: May, 1972.

HENDER SON, J.; SCOTT, J. Securitization. New York: New York Institute of Finance, 1988.

HULL, John, Options, Futures and Other derivatives. 5 Ed. New Jersey: Prentice Hall, 2002.

INTEGRAL TRUST Serviços Financeiros. Seminário Internacional, Novos Paradigmas em Securitização, FIDC - Fundos de Recebíveis e Derivativos de Crédito. São Paulo: 21 de junho, 2006.

JAMENSON, Constance H.; LLP, Katten Muchin; GHENT, Gina S.- Evolution of the Credit Derivatives Market: where we were, where we are and where we are going; CIBC World Markets Corp., 2005.

JENSEN, M., MECKLING, W. - Theory of the firm: managerial behaviour, agency costs and ownership structure: J. Financial Economics, October, 1976.

JOHNSTON, Jack, DINARDO, John. - Econometric Methods. 4 edition. New York: McGraw-Hill, 1999.

KAPLAN, Abraham. - Conduta na Pesquisa: metodologia para as ciências do comportamento, 2ª ed., São Paulo: EPU, 1975. 
KAYO, Eduardo Kazuo. - Estrutura de Capital e Oportunidades de Crescimento: Uma Análise dos Determinantes do Endividamento em Diferentes Contextos Empresariais. Dissertação de mestrado - FEA / USP, 1997.

KARLEY, N. K. and WHITEHEAD C. - The mortgage-backed securities market in the U.K.: Developments over the last few years. Housing Finance International, vol. 17, n. 2, p. 31-36: Chicago, 2002.

KLIR J., YUAN B. - Fuzzy sets and fuzzy logic: theory and application. Prentice Hall: Englewood Cliffs NJ., 1995.

KONSTANTINOS, N. P.; TSOUKALAS, L. H.; BOURBAKIS, N. G.; BRUN, M. J. and HOUSTIS, E. N. - Financial prediction and trading strategies using neurofuzzy approaches. IEEE Transactions on systems, man, and cybernetics - Part B: Cybernetics, VOL. 28, NO. 4, 1998.

KOTHARI, Vinod. Securitization: The Financial Instrument of the New Millennium. Calcuta. Academy of Financial Services, 1999.

KRAMER, B. - Residential securitization in Japan: The outlook for growth and performance. Housing Finance International, vol. 14, n. 4, p. 24 -31: Chicago, 2000.

LAGRANGE, J.B. - Analyse implicative d'un ensemble de variables numériques; application au traitement d'un questionnaire aux réponses modales ordonnées. Revue de Statistiques Appliquées : XLVI (1), p. 71-93, 1998.

LAKATOS, Eva Maria. MARCONI, Marina de Andrade. Metodologia do Trabalho Ciêntifico. São Paulo, Editora Atlas : 3ª ed., 2001.

LEE, J. - Mortgage securitization in Korea. Housing Finance International, vol.17, n.3, p. 24 : Chicago, 2003.

LEE, C.C. - Fuzzy logic in control systems: fuzzy logic controller - parts I \& II, IEEE Transactions on Systems: Man and Cybernetics, vol. 20, no.2, pp. 404-435, 1990.

MANDELKER, G.; RHEE, S. The Impact of Degrees of Operating and Financial Leverage on Systematic Risk of Common Stock. Journal of Financial and Quantitative Analysis, p.45-47, 1984.

MANSINI, R., SPERANZA, M. G. - A multidimensional knapsack model for assetbacked securitization. The Journal of the Operational Research Society, vol. 53, n. 8, p. 822: Oxford, 2002.

MARCONI, Marina de Andrade - Fundamentos de Metodologia Científica: Editora

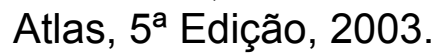

MATIAS, Arnaldo Saraiva. Titularização: um novo instrurmento. Revista de Direito Mercantil, Industrial, Econômico e Financeiro, São Paulo, v.112, 1998.

MATTAR, Fauze N. - Pesquisa de Marketing. Compacta, 1996. 
MEIRELLES, José Carlos J. S.; BENTIVEGNA, Enrico Juca - Securitização no Brasil - Pinheiro Neto Advogados: Biblioteca Uqbar, 2003.

MENDEL, J.M. - Fuzzy logic systems for engineering: a tutorial, Proceedings of the IEEE: vol. 83, no. 3, pp. 345-377, 1995.

MILLER, Merton H., Financial Innovation: The Last Twenty Years and the Next, The Journal of Financial and Quantitative Analysis: vol.21, n4, pp.459-471, 1986.

MIRANDA, Pontes de.-Tratado de Direto Privado . São Paulo: Ed. Campus, 1972.

MOODY'S Investor Service - Desmistificando Securitização Para Investidores sem Proteção de Garantias: Global Credit Research, 2003.

MOODY'S Investor Service - Global Credit Research, Industrial Company Rating Methodology: Moody's Rating Methodology, 1999.

MOODY'S Investor Service - A Evolução dos FIDCs no Mercado de Securitização Brasileiro: Relatório Especial, Finanças Estruturadas; Outubro, 2005.

MOODY'S Investor Service - Moody's Approach to Rating Latin American Residential Mortgage Backed Securities - Rating Methodology, Structured Finance: May, 2002.

MOODY'S Investor Service - A Guide for Market Participants to Monitoring Moody's Credit Opinions: Moody's Special Comment; July, 1998.

MOODY'S Investor Service - Introdução aos Ratings da Moody's - Comentário Especial: Maio, 1999.

MODIGLIANI, F., MILLER, M. - The cost of capital, corporation finance and the theory of investment. American Economic Review: June, pp. 261-297, 1958.

MODIGLIANI, F., MILLER, M. - Taxes and the cost of capital, a correction. American Economic Review: June, pp. 433-443, 1963.

MODIGLIANI, F., MILLER, M. - The Cost of Capital, Corporation Finance, and the theory of Investment: Reply. American Economic Review, Nashville: American Economic Association, June, 1965.

MODIGLIANI, F., MILLER, M. - Some Estimates of the Cost of Capital in the Electric Utility Industry. American Economic Review: June, p.333-391, 1966.

MORETTIN, Pedro A.; HAZZAN, Samuel; BUSSAB, Wilton de O. - Cálculo, Funções de uma e várias variáveis: Editora Saraiva, 2005.

NETER, John; KUTNER, Michael H.; NACHTSHEIM, Christopher J.; WASSERMAN, William. Applied Linear Regression Models. 3 ed. Chicago: Irwin, 1996. 
NORONHA, llene Patrícia de - Securitização de Recebíveis Comerciais e Industriais: Tese de Doutorado - FEA- Universidade de São Paulo, 2004.

NORUSIS, Marija J. SPSS 8.0 guide to data analysis. New Jersey: Prentice-Hall, 1998.

O'CONNELL, B.T., RATNATUNGA, J. and SMYRNIOS, K.X., Critical Factors in Securitization of Financial Assets: Evidence from Australia, Journal of Applied Finance, (published by the FMA, formerly known as Financial Practice and Education), Vol.10, No.2: Fall/Winter, 2000.

ODENBACH, M. - Mortgage securitization: what are the drivers and constraints from an originator's perspective (Basel I/Basel II)?. Housing Finance International, vol. 17, n. 1, pág. 52-62: Chicago, 2002.

ODA, André Luiz. Analise da Relação Entre Indicadores Contábeis e Betas de Mercado das Empresas Brasileiras Negociadas na Bolsa de Valores de São Paulo no Período 1995-2003, Tese de Doutorado - FEA/USP, 2004.

ODÁLIO, José dos Santos. Avaliação de Empresas - Cálculo e Interpretação do Valor das Empresas, Saraiva, 2005.

OLDFIELD, G. S. - Making markets for structured mortgage derivatives. Journal of Financial Economics, vol. 57, n. 3, p. 445: Amsterdam, 2000.

OLIVEIRA, Edson Ferreira, Contribuição à Modelagem de Avaliação de Empresas em Condições de Risco. Tese Doutorado - Faculdade de Economia, Administração e Contabilidade da Universidade de São Paulo, 2001.

PINHEIRO, Juliano Lima - Mercado de Capitais - Fundamentos e Técnicas $-3^{a}$ Edição: Atlas / Bovespa, 2005.

POINDEXTER, G. C. and Cartaya, W. V. - The emerging secondary mortgage market in Latin America. The George Washington International Law Review, vol. 34, n. 2, p. 257-286: Washington, 2002.

POPPER, Karl R. - A Lógica da Pesquisa Científica, Ed. Cultrix, 1975.

RABBAT, Marcelo - Gerenciamento de Uma Carteira de Recebíveis: Uma Abordagem de Teoria de Controle - Tese de Doutorado - Escola Politécnica da Universidade de São Paulo, 2002.

REQUIÃO, Rubens. Curso de Direito Comercial. $21^{\text {a }}$ ed. V.2, São Paulo: Saraiva, 1998.

REMPEL, O.Thomas; KLINGELER, Rainer; MARTIN, Peter - An Application of the Credit Risk Model - Credit Risk, Models and Management - Risk Books - Second Edition, 2004. 
ROSE, Peter S. - Money and Capital Markets. Financial Institutions and Instruments in a Global Marketplace. McGraw-Hill, 2000.

ROSS, Stephen; WESTERFIELD, Randolph W.;JAFFE, Jeffrey F. Administração Financeira. Corporate Finance, $1^{a}$ ed. São Paulo: Ed. Atlas, 1995.

ROSS, Stephen; WESTERFIELD, Randolph W.;JAFFE, Jeffrey F. Administração Financeira. Corporate Finance, $2^{\mathrm{a}}$ ed. São Paulo: Ed. Atlas, 2002.

RUBINSTEIN, Mark E., A mean-variance Synthesis of Corporate Financial Theory. Journal of Finance. New York: The American Finance Association, vol. 28, issue 2, p. 82-95: June, 1973.

RUBINSTEIN, Mark E., The Valuation of Uncertain Income Streams and the Pricing of Options, Bell Journal of Economics, Vol. 7, issue 2, p.407-425, 1976.

SALOMÃO NETO, Eduardo - O Trust e o Direito Brasileiro - LTR, SP, 1996.

SCHAL, Ingo - Internal Ratings for Corporate Clients - Credit Risk, Models and Management - Risk Books - Second Edition, 2004.

SANVICENTE, António Zoratto; MINARDI, Andrea M.A. Fonseca - Migração de Risco de Crédito de Empresas Brasileiras: Uma Aplicação de Análise de Clusters na Área de Crédito: IBMEC, 1999.

SAUNDERS, Anthony - Financial Institutions Management. Irwin, 1997.

SAUNDERS, Anthony - Medindo o Risco de Crédito - Novas abordagens para value at risk e outros paradigmas. Qualitymark: Serasa, 2000.

SARTORIS, Alexandre - Estatística e Introdução à Econometria. São Paulo: Editora Saraiva, 2003.

SECURATO, José Roberto. Crédito Análise e Avaliação do Risco. São Paulo: Editora Saint Paul Institute of Finance, 2002.

SECURATO, José Roberto. Decisões Financeiras em Condições de Risco. São Paulo: Editora Atlas, 1996.

SELLTIZ, C., JAHODA, M., COOK, S.W. Métodos de Pesquisa nas Relações Sociais. São Paulo: EPU, 1965.

SINGH, A. J. - The evolution of innovative debt and equity structures: The securitization of US lodging real estate finance Briefings. Real Estate Finance, vol. 2, n. 2, p. 139-161, London, 2002.

SOUSA, Aluísio José Maria de; REGO, Antonio Serafim; LINS FILHO, João Batista Correia; LYRA, José Hailton Bezerra; COUTO, Luiz Alburquerque;SILVA, Manuelito Gomes; HEGENBERG, Leônidas. Iniciação à Lógica e à Metodologia da Ciência. São Paulo: Cultrix, 1976. 
SOUSA, Almir Ferreira de. - Fatores Que Contribuem para a Empresa Agregar Valor - Tese de Livre Docência - FEA/USP, 2000.

SOUSA, Almir Ferreira de; LUPORINI, Carlos Eduardo de Mori; SOUZA, Milanez Silva de - Gestão do Capital de Giro - Caderno de Pesquisas em Administração, São Paulo, V.1, N³, $2^{\circ}$ Semestre, 1996.

SOUSA, Almir Ferreira de; MENEZES, Edgard J. Carbonell - Estratégia, Crescimento do Capital de Giro - Caderno de Pesquisa em Administração, Volume 2, N 5, 2 semestre, 1997.

SOUSA, Almir Ferreira de; FREITAS, Antonio Airton Carneiro de; LUXO, José Carlos Augusto;ROCHA, Ricardo Humberto; Asset-Backed Securitization of Brazilian Companies: fuzzy and implicative satistical analysis of debt in profitability. Global Finance, 2006.

SOUTO, Marcos Juruena Villela; ROCHA, Henrique Bastos - Securitização de Recebíveis de Royalties do Petróleo - Revista Direito - Rio de Janeiro, V.5, n¹0, Julho/Dez, 2001.

SPAGNOLO, F.; GRAS, R. - A new approach in Zadeh's classification: fuzzy implication through statistic implication. IEEE: 0-7803-8376-1/04, 2004.

STANDARD \& POOR'S - Critérios de Ratings Corporativos Globais - Ratings Corporativos -América Latina; 2000.

STANDARD \& POOR'S - Escala Global Standard \& Poor's - Credit Ratings Rating Definitions: Novembro, 2002.

STANDARD \& POOR'S - Critérios, Metodologia e Definições - Governança Corporativa, Escores e Avaliações: Julho, 2003.

STEVENSON, William J. - Estatística Aplicada à Administração. Harbra -2001.

STEWART, B., The Quest for Value. Harper Business: New York, 1990.

STUBER, Walter Douglas; BENTIVEGNA, Enrico Jucá e FIZZOLA, Henrique Bonjardim - O Instituto da Securitização de Créditos no Brasil, Notas Técnicas Securitização de Créditos Financeiros, 05 de Abril, Amaro, Stuber \& Advogados Associados, 1999.

TONETO, Rudinei Junior - Financiamento de Longo Prazo no Brasil - Da Reforma Financeira de 1964 aos anos 90: Expansão, Crise e Novas Tendências - Tese de Doutorado - FEA/USP, 1996.

VAN HORNE, James C. - Financial Management and Policy. New Jersey: Prentice Hall, 1995. 
VEDROSSI, Alessandro Olzon - Securitização de Recebíveis Imobiliários - Uma Alternativa de Aporte de Capitais para Empreendimentos Residenciais no Brasil Dissertacão - Escola Politécnica da USP, 2002.

VENTURA, Eloy Câmara. A Evolução do Crédito. São Paulo, Ed. Campus - 2000.

WESTON, J.Fred.; BRIGHAM, Eugene F.; Fundamentos da Administração Financeira: ED. Makron Books, 10ª edição, 2000.

WOLFE, Simon - Structural Effects of Asset-Backed Securitization - The European Journal of Finance 6, 353-369, 2000.

WOOLDRIDGE, Jeffreym - Introductory Econometrics: A modern Approach, Ed. Ohio, Thomson South - Western College Publishing, 2003.

ZADEH, L.A. - Fuzzy sets, Information and Control, vol.8, pp. 338-353, 1965.

ZADEH, L.A. - Outline of a new approach to the analysis of complex systems and decision processes, IEEE Trans. Systems, Man \& Cybernetics, vol. 3, pp. 28-44, 1973.

ZADEH, L. A. - Toward a generalized theory of uncertainty (GTU) - an outline. Information Sciences, Elsevier, Vol. 172, 1-40, 2005 


\section{ANEXOS}

\section{Anexo I}

Empresas que utilizaram a securitização de ativos no período de 2000 a 2006

\begin{tabular}{|c|c|c|}
\hline Empresas & Período & $\begin{array}{c}\text { Tipo de } \\
\text { recebível }\end{array}$ \\
\hline Acesita & agosto-2000 & Exportação \\
\hline Triken & maio-2000 & Local \\
\hline Cia Vale do Rio Doce & setembro- 2000 & Exportação \\
\hline Aracruz Celulose & fevereiro-2002 & Exportação \\
\hline Braskem S/A & junho-2002 & Exportação \\
\hline Companhia Siderúrgica de Tubarão & março-2003 & Exportação \\
\hline Sadia S/A & maio-2003 & Local \\
\hline Telesp Celular S/A & julho-2003 & Local \\
\hline Pão de Açúcar & outubro-2003 & Local \\
\hline Perdigão & outubro-2003 & Local \\
\hline Petroflex & dezembro-2003 & Local \\
\hline Caterpillar & dezembro-2003 & Local \\
\hline Copesul & fevereiro-2004 & Local \\
\hline CPFL Piratininga & fevereiro-2004 & Local \\
\hline Furnas I & outubro-2004 & Local \\
\hline Gradiente Eletrônica & outubro-2004 & Local \\
\hline CESP & dezembro-2004 & Local \\
\hline FICAP-Cabos Elétricos & abril -2005 & Local \\
\hline Furnas II & maio-2005 & Local \\
\hline Quality Energia & junho -2005 & Local \\
\hline Cataguazes Leopoldina & julho-2005 & Local \\
\hline Telefônica & julho-2005 & Local \\
\hline GP Aetatis / GP Investments & agosto-2005 & Local \\
\hline Zoomp & setembro-2005 & Local \\
\hline Gradiente Eletrônica & setembro-2005 & Local \\
\hline CESP & outubro-2005 & Local \\
\hline Motorola Industrial & outubro-2005 & Local \\
\hline Anhanguera/Grupo Siemens & novembro-2005 & Local \\
\hline Caiuá & janeiro-2006 & Local \\
\hline Cemig & janeiro-2006 & Local \\
\hline CEEE & fevereiro-2006 & Local \\
\hline Sabesp & março-2006 & Local \\
\hline Grupo Brasil & março-2006 & Local \\
\hline Fornecedores Petrobras & março-2006 & Local \\
\hline Tigre Industrial & março-2006 & Local \\
\hline Marcopolo & abril-2006 & Local \\
\hline Cesp & agosto-2006 & Local \\
\hline Dedini-Dulcini & agosto-2006 & Local \\
\hline Saneamento Sergipe & setembro-2006 & Local \\
\hline Cobra Comercial & outubro-2006 & Local \\
\hline Finexia Telecon & novembro-2006 & Local \\
\hline FIEP Industrial & novembro-2006 & Local \\
\hline Petrobras & dezembro-2006 & Local \\
\hline
\end{tabular}

Fonte: Anbid e CVM 
Anexo II

Ações Selecionadas para o Cálculo do Beta de Mercado

\begin{tabular}{|l|l|c|c|}
\hline Nome da Empresa & Nome completo da empresa & Classe da Ação & Código na Bolsa \\
\hline Acesita & Acesita S.A. & PN & ACES4 \\
\hline Aracruz & Aracruz Celulose SA & PNB & ARCZ6 \\
\hline Braskem & Braskem S.A. & PNA & BRKM5 \\
\hline Cataguazes & Cataguazes Leopoldina & PNA & FLCL5 \\
\hline Cesp & Cesp - Cia. Energetica de Sao Paulo & PNB & CESP6 \\
\hline CBD & Cia Brasileira de Distribuição & PN & PCAR4 \\
\hline Copesul & Copesul - Cia. Petroquimica do Sul & ON & CPSL3 \\
\hline CPFL Piratininga & Cia. Piratininga de Forca e Luz & PN & CPFP4 \\
\hline Gradiente & Gradiente Eletronica s a & PNA & IGBR5 \\
\hline Perdigao & Perdigao S.A. & ON & PRGA3 \\
\hline Petroflex & Petroflex Industria e Comercio S.A. & PNA & PEFX5 \\
\hline Sadia & Sadia S.A. & PN & SDIA4 \\
\hline Sansuy & Sansuy S.A Insdútria de Plásticos & PNA & SNSY5 \\
\hline CST & Cia Sid Tubarao & PN & CSTB4 \\
\hline Telesp & Telec. de Sao Paulo S/A-Telesp & PN & TLPP4 \\
\hline Triken & Triken S/A & PN & CPCA4 \\
\hline Telefônica & Telefônica SA & Ord & TEFC11 \\
\hline Vale Rio Doce & Cia Vale do Rio Doce & PNA & VALE5 \\
\hline Fonte: EcOnOmatica
\end{tabular}

Fonte: Economática 